\title{
Bargaining for Security: The Rise of the Pension and Social Insurance Program of the United Steelworkers of America, 1941-1960
}

Henry Edward Himes III

hhimes@mix.wvu.edu

Follow this and additional works at: https://researchrepository.wvu.edu/etd

Part of the Labor History Commons, Social History Commons, and the United States History

Commons

\section{Recommended Citation}

Himes, Henry Edward III, "Bargaining for Security: The Rise of the Pension and Social Insurance Program of the United Steelworkers of America, 1941-1960" (2019). Graduate Theses, Dissertations, and Problem Reports. 3917.

https://researchrepository.wvu.edu/etd/3917

This Dissertation is protected by copyright and/or related rights. It has been brought to you by the The Research Repository @ WVU with permission from the rights-holder(s). You are free to use this Dissertation in any way that is permitted by the copyright and related rights legislation that applies to your use. For other uses you must obtain permission from the rights-holder(s) directly, unless additional rights are indicated by a Creative Commons license in the record and/ or on the work itself. This Dissertation has been accepted for inclusion in WVU Graduate Theses, Dissertations, and Problem Reports collection by an authorized administrator of The Research Repository @ WVU.

For more information, please contact researchrepository@mail.wvu.edu. 
Bargaining for Security: The Rise of the Pension and Social Insurance Program of the United Steelworkers of America, 1941-1960

Henry E. Himes III

Dissertation submitted

to the Eberly College of Arts and Sciences

at West Virginia University

in partial fulfillment of the requirements for the degree of

Doctor of Philosophy in

History

\author{
Ken Fones-Wolf, PhD., Chair \\ Elizabeth Fones-Wolf, PhD. \\ James Siekmeier, PhD. \\ Jason Kozlowski, PhD. \\ William Gorby, PhD.
}

Department of History

Morgantown, West Virginia

2019

Keywords: pensions, healthcare, public/private welfare state, collective bargaining, public welfare, private welfare, United Steelworkers of America, unions, Social Security, 1946 Steel Strike, 1949 Steel Strike, 1959 Steel Strike, Philip Murray, David McDonald

Copyright 2019 Henry E. Himes III 


\author{
ABSTRACT \\ Bargaining for Security: The Rise of the Pension and Social Insurance Program of the United \\ Steelworkers of America, 1941-1960
}

Henry E. Himes III

This dissertation charts the United Steelworkers of America's (USWA) quest to win long term welfare security for its members from 1941 to 1960 . The study focuses on external and internal events and issues that led the union to seek pensions and social insurance at the bargaining table in 1949, and ultimately, to enhance their private security at the bargaining table throughout the 1950s. Although labor's ability to influence the passage of national health care was greatly curtailed by a rise in conservative politics during World War II and the immediate postwar era, issues beyond politics also played a role in the USWA's decision to bargain for security in 1949. Chief among these issues was a postwar retiree crisis that began in 1946. In that year, steel companies such as Inland Steel and US Steel began to force retiree steelworkers who reach the age of 65 with little to no long-term economic security. The postwar retiree crisis thus ignited a swell of rank and file demands on union leaders to bargain for better forms of private insurance and to use the union's bargaining power to end the arbitral and paternalistic nature of welfare capitalism. Consequently in 1949, after a significant strike, the USWA won a pension and social insurance program, which the union worked to expand and enhance throughout the 1950s. Although the union had used its bargaining power to secure one of the finest pensions and social insurance programs in American industry, private insurance programs were plagued by ever rising costs that ate into the wage gains of steelworkers. By 1960, after a two-year internal study of its pension and social insurance program, the USWA concluded that the indemnity (fee-forservice) insurance model was deficient and incapable of delivering the comprehensive and prepaid security the union demanded. Beyond the direct issue of welfare security, this study also sheds light on the internal union dynamics of the USWA in such a critical and influential era in American history. Moreover, the dissertation brings to light a more detailed portrayal and accounting of USWA President, Philip Murray, as he guided the union through World War II and the immediate postwar era. 
Dedicated to my father Henry E. Himes Jr. and my step-father James W. Masluk. I miss you both. 


\section{Acknowledgments}

This dissertation originated a long time ago back in Youngstown, Ohio. I had recently left the army where I had served as an artillery officer and now faced the daunting life question of "what will I do next?" At first, I was uncertain where my path would lead. I had spent some time visiting friends in Columbus, Ohio, and my experience there, particularly the many deep conversations I had with the people I had met there, enlightened me, and made me think more intensely about the perplexing questions of life and how society operated. My sojourn to Columbus thus made me more intellectually curious and sparked my desire to go to graduate school. From Columbus, I moved back home to Youngstown, Ohio, where I was accepted into the master's program of history at Youngstown State University (YSU). At YSU, I had the great fortune to obtain a graduate assistantship at the Youngstown Historical Center of Industry and Labor (YHCIL) where I worked as a museum docent and archival assistant. Coming from a working-class family_my parents were auto workers, my grandfather was a steelworker, and my great uncle and great grandfather were skilled union bricklayers - working at YHCIL was a dream come true. My time at YHCIL opened my eyes to labor history, and more specifically, to the work of Staughton and Alice Lynd. At YHCIL, I was quickly exposed to the work the Lynds had done to try and prevent the wholesale shut down of Youngstown's steel mills in the late 1970s and early 1980s. Their work during the shutdown era was fascinating and intriguing, particularly their effort to help build a coalition of people to purchase and run the Youngstown Sheet and Tube steel mill as a community and employee-owned enterprise. However, it was another issue that the Lynds were involved with that ultimately led me to my eventual dissertation topic. 
In 1986 the LTV Steel Corporation filed for chapter 11 bankruptcy and immediately canceled retiree health insurance. Moreover, a few months after the initial bankruptcy announcement, the Pension Benefit Guarantee Corporation (PBGC) took over LTV's underfunded pension plan, which led to a reduction in retiree pension payments and other hardships for steel retirees. Consequently, steel retirees, with the legal counsel of Staughton and Alice Lynd, founded Solidarity USA to fight to retain their pensions and benefits. I wrote my master's thesis on this organization. My experiences in the YSU master's program made me want to go to the next level and pursue a Ph.D., in US history. Thus, I subsequently applied to and was accepted into the history program at West Virginia University (WVU). Although I loved my master's thesis topic, I wanted to know more about how the system of private pensions and benefits originated in the steel industry. With that goal in mind, I was able to narrow down my focus and create the dissertation topic presented here. It was a long, arduous, and tedious process but in the end, I am happy with the final product and I look forward to eventually expanding this dissertation into a publishable monograph.

Nothing in life is done alone. Rather, we are all the beneficiaries of social connections that support, love, encourage, and critique what we do in life. Whether that be our friends, family, community, peers, or advisors, we are hardly autonomous individuals, but instead, we owe our individual accomplishments to a myriad of people that have helped us on our journey. First of all, a dissertation cannot be written without sources. The bulk of the sources used in this dissertation, in particular, the USWA International Executive Board (IEB) minutes, came from the Penn State Special Collections library, which is the repository for the USWA. I want to thank the great staff at Penn State, they are all so knowledgeable, professional, and courteous and made my trips there a wonderful experience. In particular, I want to thank Jim Quigel, Head of 
the Historical Collections and Labor Archives at the Penn State Special Collections Library. Jim is so knowledgeable about the USWA collection and I greatly enjoyed some of our friendly chats about labor history.

Next, I really would like to thank all my friends and advisors at Youngstown State University. If it was not for my experiences at YSU, I would have never thought about pursuing a Ph.D., in history. I am deeply indebted to my master's thesis advisor Dr. Tom Leary. You awoke my consciousness about class relationships and the importance of labor history, and I sincerely thank you for that. I also want to thank Dr. Martha Pallante, Dr. Donna DeBlasio, and Dr. Diane Barnes for welcoming me into the YSU history program, always providing constant encouragement, and giving me the opportunity to work at the YHCIL. I also want to thank my peers at YSU in particular Jonathan Kinkead, Krista McCart, Joe Kusluch, Nathan Pavalko, Rachel Doddato, and Joe Paloski.

I want to thank West Virginia University for having me; I cannot think of many other places better suited to study labor and working-class history. The WVU history department has some of the finest scholars practicing their craft, and the always friendly atmosphere was a true joy to experience. I am infinitely indebted to the faculty of WVU, which has provided me with a world-class graduate education. Specifically, I want to thank Dr. Elizabeth Fones-Wolf, Dr. Joshua Arthurs, Dr. Krystal Frazier, and Dr. James Siekmeier, you are all outstanding human beings and I thank you for the knowledge and guidance you have given me over the years. I am also indebted to the greatest group of peers and friends a person could ask for. To Marc Sanko, Kenny Kolander, Luke Gramith, Chuck Welsko, Justin Power, Zach Cowsert, Gregory Michna, Hal Gorby, Tyler Krahe, Scott Thompson, Alex Burns, Cole Volman, Andrew Brown, and 
Brandon Roos, thank you for being my friends and I look forward to reading about all of your accomplishments in the future.

Next, I want to thank the two scholars and mentors that have most significantly helped me to successfully complete my Ph.D., and who have vastly expanded my knowledge of US labor and working-class history, Dr. Ken Fones-Wolf and Dr. Sam White. From day one, Ken has always believed in me and believed in my topic of interest. Through various independent studies, Ken broadened my knowledge and understanding of the world of work and workers and I am deeply indebted to him for that. Moreover, without Ken's guidance and tough love, this dissertation would never have been completed. From the bottom of my heart, thank you, Ken! I also want to thank Dr. Sam White. Midway through my Ph.D., Sam gave me the opportunity to work as a graduate research assistant in the WVU Labor Studies program. There I had the great privilege to learn more about an often overlooked and under-studied segment of labor history, the building trades. The knowledge, skills, and experience I have gained working for Sam in Labor Studies are incalculable and I thank Sam for his guidance and mentorship.

Lastly, I want to thank my friends and family for always being there and always loving me. During the Ph.D. process, I unfortunately lost the two greatest men in my life, my father Henry Himes Jr. and my step-father James Masluk. I always say that I am the beneficiary of having the love and support of two fathers when so many children do not have one. Both of these men shaped who I am today, and they taught me about life and labor. Both were working class union guys who were very different from each other, but each had endearing qualities and they loved me unconditionally. I love and miss you tremendously! I also want to thank my mother Shirley Masluk for always being there for me and supporting me in all that I do. You are my rock and I love you more than anything! To my sister Tracy Evans, thank you for all the 
love and support you have given me throughout this journey and for all the great food you always make for me to eat! To my friends, my love for you has no bounds. To Rob McMillen, Kevin Herrholtz, Kevin Ruminski, and Ron Sturgeon, you guys have always been there for me and I couldn't ask for a better group of friends! 


\section{Table of Contents}

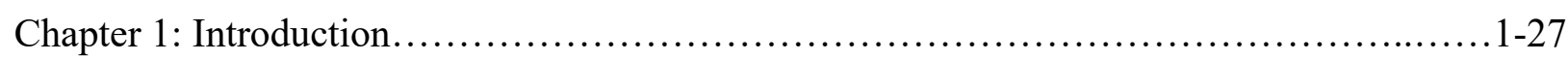

Chapter 2: WWII and the USWA's Quest for Security...............................28-78

Chapter 3: Postwar Reconversion and the 1946 Steel Strike......................... $79-134$

Chapter 4: The USWA's Path to Private Security: The Postwar Retiree Crisis, Politics, and

Postwar Communism.......................................................... 135-178

Chapter 5: Bargaining for Security: The USWA and 1949 Steel Strike..................179-211

Chapter 6: The USWA Pension and Social Insurance Program from 1949 to

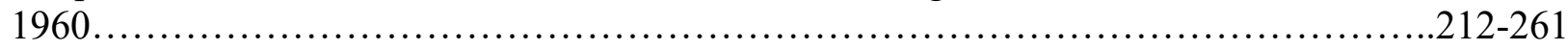

Chapter 7: Conclusion: The End of the Road....................................262-270

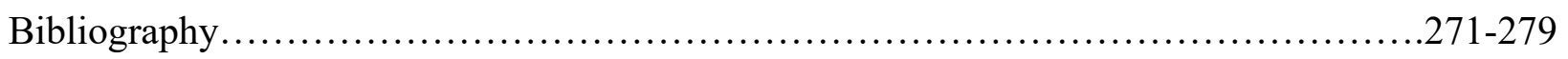




\section{Chapter 1: Introduction}

\section{New Deal Liberalism, the Labor Movement, and the Rise of Postwar Affluence a}

\section{Contextual Overview}

The quarter century after World War II was a time that witnessed a high degree of economic prosperity and social mobility for many Americans. At the close of the war, the U.S. retained global industrial supremacy as former industrial competitors such as Germany and Japan lay in ruins. In addition, the end of the war marked the beginning of the so-called "liberal consensus," built on a broad class acceptance of Keynesian macro-economic growth policies, anti-communism, rising consumerism, and a more amicable labor-management relationship tied to collective bargaining. However, by the mid-1970s, postwar prosperity began to stagnate, the liberal consensus started to unravel, the economy began to deindustrialize, and management more overtly challenged labor. ${ }^{1}$

One can find the origins of the postwar social order in the era of the Great Depression and WWII. The rise of Franklin D. Roosevelt's New Deal in the aftermath of the most significant capitalist economic crisis in world history worked legislatively and psychologically to stabilize the economy and establish a baseline framework for public welfare security. Although the New Deal increased the power and presence of the Federal government in the lives of most Americans as well as worked to usher in broad economic reforms, it nonetheless facilitated the preservation of capitalism. ${ }^{2}$ However, the working class of the Depression era found in the Democratic party and FDR's New Deal a new sense of citizenship as well as a Federal

\footnotetext{
${ }^{1}$ For a comprehensive post-World War II overview see Joshua Benjamin Freeman, American Empire: The Rise of a Global Power, the Democratic Revolution at Home, 1945-2000 (New York: Viking, 2012).

${ }^{2}$ For a look at how the New Deal transitioned away from "reform" to a Keynesian model of capitalistic growth economics see Alan Brinkley, The End of Reform: New Deal Liberalism in Recession and War (New York: Alfred A. Knopf, 1995).
} 
government more sympathetic to their needs (although skewed in favor of the white male working class). The Wagner Act and the Social Security Act of 1935, along with the Fair Labor Standards Act of 1938, gave the working class more access to security in the form of old age pensions, unemployment compensation, a more standardized and regulated workday, and the legal right to form a union and bargain collectively. ${ }^{3}$

The start of World War II increased the power and presence of the Federal government even further in the lives of American citizens and worked, via massive government spending, to pull the economy out of the Depression. Through wartime government agencies such as the National War Labor Board (NWLB), War Production Board (WPB), and the Office of Price Administration (OPA), labor and business leaders jockeyed for power and worked to pursue their class interests. "Labor Liberals" such as Philip Murray and Walter Reuther attempted to achieve a progressive postwar vision built on a full employment economy, the annual wage, and expanded federal welfare security to include a national healthcare system. Business worked instead to thwart the passage of progressive postwar legislation, pushed to secure their "right to manage" private enterprise, and worked to reshape their tarnished image in the postwar era. Thus, at the close of the war, business, along with a rising conservative political coalition, was able to curtail the reform agenda of the early New Deal as well as the Social Democratic vision of labor liberals. By 1946, labor could no longer feasibly bring forth their vision of a strong

\footnotetext{
${ }^{3}$ For a solid overview of the New Deal era, with an emphasis on how the New Deal benefitted, or failed to benefit, disparate social groups in America see Roger Biles, A New Deal for the American People (DeKalb: Northern Illinois University Press, 1991); To better understand how mass consumer culture and generational differences worked to homogenize once insular and disparate immigrant communities leading to the rise of the New Deal political coalition of the 1930s see Lizabeth Cohen, Making a New Deal: Industrial Workers in Chicago, 1919-1939 (New York: Cambridge University Press, 2008).
} 
Social Democratic public welfare state, and hence, opted to use their collective economic power to achieve private welfare security via collective bargaining. ${ }^{4}$

In a postwar period defined initially by limited global competition, business was more willing to work with labor to meet their wage and private welfare security demands. Generally speaking, the collective bargaining process in heavy industries such as steel, observed throughout the 1950s and 1960s an overall increase in wages and private welfare benefits. However, these contracts were not total victories because business routinely offset wage and benefit increases with price increases leading to inflation, and many deficiencies such as out of control medical costs plagued the indemnity insurance model of private welfare protection. ${ }^{5}$ Thus, as long as American industry had limited global competition and could pass the cost of higher wages and benefits on to consumers, the postwar collective bargaining relationship described above held firm. ${ }^{6}$

\footnotetext{
${ }^{4}$ For a look at how large business interests influenced the process of war mobilization see Brian Waddell, "Economic Mobilization for World War II and the Transformation of the U.S. State," Politics \& Society 22, no. 2 (June 1, 1994): 165-94; For a look at the CIO's role during World War II and the inability of "labor liberals" to achieve their postwar reform vision see Nelson Lichtenstein, Labor's War at Home: The CIO in World War II (New York: Cambridge University Press, 1982); For a comprehensive analysis on the life of labor leader Walter Reuther see Nelson Lichtenstein, The Most Dangerous Man in Detroit: Walter Reuther and the Fate of American Labor (New York: Basic Books, 1995); To better understand the business community's effort to thwart the "labor liberal" agenda, secure their postwar "right to manage," and "sell" a more positive image of business to the American people see Howell John Harris, The Right to Manage: Industrial Relations Policies of American Business in the 1940s (Madison: University of Wisconsin Press, 1982) and Elizabeth A. Fones-Wolf, Selling Free Enterprise: The Business Assault on Labor and Liberalism, 1945-60 (Urbana: University of Illinois Press, 1994); For a concise analysis on the rise of privately bargained for welfare benefits in industrial unions see Nelson Lichtenstein, "Labor in the Truman Era: Origins of the 'Private Welfare State,"” in Michael J. Lacey eds., The Truman Presidency (New York: Cambridge University Press, 1989).

${ }^{5}$ Indemnity insurance is an insurance model that most Americans today are familiar with even if they do not recognize or understand the term. In essence, indemnity insurance is a fee-for-service model of insurance coverage. For instance, if you have an indemnity-based health insurance policy whether bought on an individual basis or acquired through your employer, that insurance is designed to pay a predetermined amount of money to the physician that treated you. Indemnity insurance is thus different from other types of insurance/health care models such as prepaid programs that charge one fee for all health services and utilize a team of salaried physicians. In 1949, the USWA opted for indemnity insurance coverage; however, quickly discovered throughout the 1950s that indemnity insurance and fee-for-service physicians could not adequately regulate and control medical costs.

${ }^{6}$ For a comprehensive overview of the postwar Keynesian growth economy see Robert M. Collins, More: The Politics of Economic Growth in Postwar America (New York: Oxford University Press, 2000); To better understand the economics of deindustrialization see Bennett Harrison and Barry Bluestone, The Great U-Turn: Corporate Restructuring and the Polarizing of America (New York: Basic Books, 1993) and Barry Bluestone and Bennett
} 
In the ostensible "era of affluence," roughly 1950 to the mid 1970s, workers and their unions relied heavily on the collective bargaining process to better their condition. Unions won higher wages with periodic cost of living adjustments, supplemental unemployment benefits (SUB) to help with long periods of unemployment, vacations (especially in the steel industry), and increased long-term security in the form of privatized pensions and healthcare benefits. Although this postwar relationship proved materially beneficial for unionized workers (and to a smaller degree non-unionized workers), postwar union members would witness, especially throughout the era of deindustrialization and the rise of global corporatism, a decrease in their ability to achieve vigorous shop floor democracy, due in great part to the establishment of hierarchical and bureaucratic unions and slow and cumbersome grievance systems. Workers also failed to achieve economic democracy in the form of having a legitimate voice in the company's investment and decision-making process. ${ }^{7}$ Moreover, the deindustrialization of America also made more pronounced the limits of private security as many corporations

\footnotetext{
Harrison, The Deindustrialization of America: Plant Closings, Community Abandonment, and the Dismantling of Basic Industry (New York: Basic Books, 1982); For a comprehensive historical analysis on the motivations, decisions, processes, and consequences of capital flight see Jefferson Cowie, Capital Moves: RCA's 70-Year Quest for Cheap Labor (New York: The New Press, 2001); For an insider's glance at the immediate turmoil and despair of deindustrialization in Youngstown, and the subsequent spirited community response to deindustrialization see Staughton Lynd, Fight Against Shutdowns: Youngstown's Steel Mill Closings (San Pedro: Singlejack Books, 1982); For an understanding of the long term social and cultural consequences of deindustrialization in Youngstown see Sherry Lee Linkon, Steeltown U.S.A: Work and Memory in Youngstown (Lawrence: University Press of Kansas, 2002); also see David Bensman, Rusted Dreams: Hard Times in a Steel Community (New York: McGraw-Hill, 1987); Jefferson Cowie and Joseph Heathcott, Beyond the Ruins: The Meanings of Deindustrialization (Ithaca: ILR Press, 2003).

${ }^{7}$ For an analysis on labor's postwar acceptance of the social relationships of capitalism and labor's ultimate disassociation from their 1930s emphasis on workplace democracy see Nelson Lichtenstein, State of the Union: A Century of American Labor (Princeton: Princeton University Press, 2002); Since the economic crash of 2007 and 2008 there has been increased criticism levied on capitalism and the social relationships that capitalism creates. Many contemporary Marxian scholars such as economist Richard D. Wolff have attempted to interject a critical Marxian perspective into our contemporary economic debate (a debate in which neoclassical economic theory reigns hegemonic). Wolff, and his longtime colleague Stephan A. Resnick, has worked to move Marx's critique of capitalism away from an association with top down state controlled socialism, and instead, have argued for a more decentralized bottom up socialism tied to a new analytical emphasis on "surplus value" distribution and workplace democracy/ownership. See for instance Richard D. Wolff, Democracy at Work: A Cure for Capitalism (Chicago: Haymarket Books, 2012).
} 
mismanaged their pension and social insurance funds, or in times of crises such as a bankruptcy, unilaterally decreased and/or eliminated benefits. ${ }^{8}$

The weaknesses and limits of the nation's bifurcated welfare system, which grew more pronounced in the last quarter of the twentieth century, sparked scholars to study how the public/private welfare state developed over the course of U.S. history. Most of these histories focus on how national politics, business organizations, or individual labor leaders influenced the development of the public/private welfare state. However, outside of Richard Mulcahy's, Social Contract For The Coal Fields: United Mine Workers Welfare and Retirement Funds, there are very few detailed and comprehensive studies on how significant and influential labor organizations attempted to bring long-term welfare security to their members. ${ }^{9}$ More specifically, the current body of public/private welfare state scholarship is missing a detailed and comprehensive study of how the United Steelworkers of America, arguably the most significant industrial union in American history, navigated the tumultuous political and economic environment of World War II and the immediate postwar era to bring long-term welfare security to its membership.

One example of the current literature is Edward D. Berkowitz's America's Welfare State: From Roosevelt to Reagan. Berkowitz writes a comprehensive narrative that charts the establishment, growth, and evolution of the postwar welfare state. The author focuses his attention on top-level leaders of institutions as well as healthcare technocrats. Berkowitz, who was writing in an era that was witnessing the decline of the welfare state and postwar liberalism,

\footnotetext{
${ }^{8}$ For a look at the impact of the LTV Steel Bankruptcy on USWA retirees from Youngstown, Ohio see Alice and Staughton Lynd, “We are All We've Got': Building a Retiree Movement in Youngstown, Ohio" in Gary Bellow and Martha Minow, eds., Law Stories (Ann Arbor: University of Michigan Press, 1998).

${ }^{9}$ Richard P. Mulcahy, Social Contract For Coal Fields: United Mine Workers Welfare \& Retirement Funds, (Knoxville: University of Tennessee Press, 2001).
} 
sought to provide his contemporary audience with a comprehensive historical look at the development of the postwar welfare state. Berkowitz thus begins in the 1930s with the rise of the New Deal and the establishment of Social Security. He then charts the unique growth of the welfare state in the era of the "liberal consensus," and finally, he describes the unraveling of the liberal consensus and the political implications associated with the welfare state and the end of the liberal order. ${ }^{10}$

Jacob Hacker expands the scholarship on America's postwar welfare state in The Divided Welfare State: The Battle Over Public and Private Social Benefits in the United States. ${ }^{11}$ This work, too, is mainly focused on the institutional development of the postwar welfare state and does not address the influence of the rank-and-file on the creation of America's "divided" welfare system. Hacker, instead, broadens our understanding of the complexity of the welfare state arguing that the postwar welfare state has both a public dimension and a private dimension. He suggests that scholars for too long have only concentrated on the public dimension, and by doing so they have missed the dialectical nature of how the private welfare state shapes and molds the public welfare state. Hacker thus writes, "If the limits of public social programs fostered the private side of U.S. social policy, America's private path also contributed momentously to the limits of public programs — and, indeed, remains pivotal to the politics and the future of the American welfare state."12

Expanding on Hacker's public/private welfare state thesis is Marie Gottschalk's The Shadow Welfare State: Labor, Business, and the Politics of Health-Care in the United States.

\footnotetext{
${ }^{10}$ Edward D. Berkowitz, America's Welfare State: From Roosevelt to Reagan (Baltimore: Johns Hopkins University Press, 1991).

${ }^{11}$ Jacob S. Hacker, The Divided Welfare State: The Battle over Public and Private Social Benefits in the United States (New York: Cambridge University Press, 2002).

${ }^{12}$ Hacker, xiii.
} 
Gottschalk, writing in the 1990s after the Clinton's ill-fated attempt to establish a universal healthcare system, was curious as to why labor as an institution held firm to an "employer provided" healthcare system rather than throwing its full support behind a broader and more universal government program. Her main argument is that unions played a significant political role in the development of the postwar public/private welfare state, and that throughout the postwar era labor became increasingly tied to the private welfare state drawing its attention away from public welfare state issues. Gottschalk argues that historical developments such as the so called "labor management accord," the Taft Hartley Act, the Employee Retirement Income Security Act (ERISA), and the rise of "experience rated" healthcare increasingly confined labor to the private welfare system, thus limiting unified political action over the expansion of the public welfare state. She writes "the health-care issue is exceptional because the institutions of the private welfare state compound the fragmentation of public institutions. These institutions of the shadow welfare state impede efforts to forge a winning coalition anchored by organized labor." 13

Some authors, such as Alan Derickson and Colin Gordon, have tried to wrestle with the perplexing question of why, compared to many European countries, has the U.S. failed to achieve state sponsored universal healthcare. Derickson's Health Security For All: Dreams of Universal Healthcare in America focuses on the political and ideological debates surrounding the idea of universal healthcare in the United States. He looks at both the high-level politics of the political "left" and "right," and he places at the center of his analysis the issue of whether or not healthcare in the United States should be considered a universal "right." He shows that the idea of healthcare as a right had momentum throughout the Great Depression and into the war

\footnotetext{
${ }^{13}$ Marie Gottschalk, The Shadow Welfare State: Labor, Business, and the Politics of Health-Care in the United States (Ithaca: ILR Press, 2000), 6.
} 
era; however, in the postwar era the debate over healthcare as a "right" was gradually subsumed by the debate over the issue of healthcare "cost containment."14 Colin Gordon's Dead on Arrival: the Politics of Healthcare in the Twentieth-Century argues that the question of universal healthcare was dead by the 1940s. He points to a strengthened business class as well as an increase in conservative politics during and after World War II, along with race and gender issues, as being a bulwark against the creation of a universal healthcare system. Gordon also argues that the contributory principle associated with the financing mechanism of Social Security, as well as the establishment of robust private security plans, worked to limit social solidarity in an effort to create a universal healthcare system. ${ }^{15}$ Although both of these works look at social ideology vis-à-vis the issue of universal healthcare, they do not probe and analyze the beliefs and actions of rank-and-file union members or the pressures they brought to bear on labor unions to negotiate for the benefits they needed to face an insecure future.

Another top down study of the welfare state is Tracey Roof's American Labor, Congress, and the Welfare State, 1935-2010. Roof is primarily interested in analyzing the high-level politics associated with the development of the postwar welfare state. Roof argues that the bifurcated welfare state is very much a product of America's conservative political institutions, especially the U.S. Senate. Beginning in the 1930 s with the rise of the New Deal, and the subsequent rise of labor, the political environment was ripe for the creation of a baseline public welfare state. However, liberal political power proved fleeting. By the late 1930s and moving into the war era, conservative politics along with conservative political institutions placed the more progressive labor liberal agenda in a political bind. Roof argues that although labor never

\footnotetext{
${ }^{14}$ Alan Derickson, Health Security for All: Dreams of Universal Health Care in America (Baltimore: The Johns Hopkins University Press, 2005).

${ }^{15}$ Colin Gordon, Dead on Arrival: The Politics of Health Care in Twentieth-Century America (Princeton: Princeton University Press, 2003).
} 
gave up the fight for a more universal public welfare state, unions always faced the daunting political hurdle of achieving a supermajority in the U.S. Senate. Hence, conservative politics and institutions worked to either thwart, or water down, labor's more stout public welfare vision. ${ }^{16}$

Throughout the twentieth century business interests developed various strategies to mollify the threat of labor solidarity. Some businesses prior to the Great Depression took a hardline approach to the threat of unionization. These businesses used their cultural, political, and economic power to aggressively thwart any attempt at unionization. Whether it was using an extra-legal police force such as the Baldwin Felts Detective agency to protect mining interests, or private spies on the shop floor seeking to expose labor organizers and sympathizers in the steel industry, many American companies have viewed unionization as illegitimate and have openly fought workers' attempts to organize. However, as Sanford Jacoby so deftly illuminates in Modern Manors: Welfare Capitalism Since the New Deal, certain business interests have taken a different approach to thwart unionization. Rather than mobilizing forcefully against workers, business interests such as Thompson Products, Sears \& Roebuck, and Kodak as well as others looked to win the hearts and minds of their employees through the implementation of welfare capitalism. These businesses in the early twentieth century believed that the best way to limit unionization was to offer their employees better housing, healthcare, pensions, stock options, and above average wages. For these businesses, paternalism was the best strategy to preserve the social relationships of capitalism. Jacoby argues that the aforementioned companies and their pre-Great Depression welfare capitalist systems are a link to post-World War II welfare capitalist strategies. These companies, according to Jacoby, were able to weather the Great Depression, preserve their welfare capitalist programs, and thus thwart unionization in the 1930s and 1940s,

\footnotetext{
${ }^{16}$ Tracy Roof, American Labor, Congress, and the Welfare State, 1935-2010 (Baltimore: Johns Hopkins University Press, 2011).
} 
which ultimately carried into the postwar era. Once the "Age of Affluence" began to stumble, and the so-called "labor management" accord crumbled, companies such as Kodak and Sears became new models of postwar welfare capitalism. ${ }^{17}$

Jennifer Klein's work greatly helps to illuminate our understanding of the development of the public/private welfare state throughout the first half of the twentieth century, with special focus on the influence of the Great Depression, World War II, and the immediate postwar period. Klein's For All these Rights: Business, Labor, and the Shaping of America's Public-Private Welfare State, argues that the Great Depression and the subsequent rise of the New Deal helped to inculcate into the minds of the American people a newfound understanding and desire for security. Private insurance companies, which had developed private group insurance plans in the first three decades of the twentieth century, primarily as a mechanism to support welfare capitalism, initially viewed public welfare programs such as Social Security as a threat to their business interest. Thus, throughout the 1930s and 1940s, group insurance companies actively mobilized to orient the public's perception of security away from publicly provided security and more towards private options. This active campaign to redefine security enabled group insurers to expand the private group insurance market, and in the postwar era, it also helped American business reestablish their managerial control via new forms of welfare capitalism. ${ }^{18}$

Although group insurance providers initially mobilized to limit the expansion of the public welfare state, gradually they had a change of heart and began to view Social Security as a baseline program of benefits that private group insurance companies could augment and enhance. Insurers also actively marketed private benefit options to American businessmen as a

\footnotetext{
${ }^{17}$ Sanford M. Jacoby, Modern Manors: Welfare Capitalism Since the New Deal (Princeton: Princeton University Press, 1997).

${ }^{18}$ Jennifer Klein, For All These Rights: Business, Labor, and the Shaping of America's Public-Private Welfare State (Princeton: Princeton University Press, 2003).
} 
way of stemming the rising tide of labor unions, which over the war period and into the postwar era, were beginning to challenge the political strength of business and the businessman's "right to manage." Klein thus writes:

As the public welfare state expanded together with the union movement, American business firms and commercial insurance companies became partners in creating and expanding nonstate alternatives to public social insurance. Using the public Social Security program as a foundation, larger firms came to offer supplemental pensions, disability wages, and unemployment benefits. Employers also provided paid sick leave, hospital insurance, medical insurance, and, less often, retiree health benefits. ${ }^{19}$

Nelson Lichtenstein has written two significant essays on the development of private social insurance during World War II and the immediate postwar period. Lichtenstein focuses much of the essays on the political and economic environment in which progressive labor leaders such as Philip Murray and Walter Reuther were operating in. Thus, these articles argue that the CIO's path to bargaining for security was primarily a factor of postwar anti-communism and the rise of a more conservative postwar politics which thwarted the enactment of progressive postwar reforms such as national healthcare. Due to these conditions, labor turned inward and sought access to long-term welfare security at the bargaining table. These seminal essays give us great insight into the political and economic conditions of the postwar era and more specifically of the actions of key labor leaders; however, they do not reveal the thoughts and actions of union members at various levels within the totality of the union's structure..$^{20}$

Lastly, Alan Derickson's essay on health insurance and the USWA describes the union's historical path to private security and finds that although the USWA opted for private health

\footnotetext{
${ }^{19}$ Ibid, 5.

${ }^{20}$ See Nelson Lichtenstein, "Labor in the Truman Era: Origins of the "Private Welfare State"” in Michael James Lacey, ed., The Truman Presidency (New York: Cambridge University Press, 1989); see Nelson Lichtenstein, "From Corporatism to Collective Bargaining: Organized Labor and the Eclipse of Social Democracy in the Postwar Era" in Steve Fraser and Gary Gerstle, eds., The Rise and Fall of the New Deal Order, 1930-1980 (Princeton: Princeton University Press, 1990).
} 
security, union leaders stressed the need to secure a voice over their private welfare plans in an effort to reduce managerial hegemony over the program. Indeed, Derickson's essay is a major catalyst for this dissertation which looks to chart the development of the USWA's pension and social insurance fund from World War II to the 1960s and provide a longer and more in-depth analysis of the USWA's path to private security. ${ }^{21}$

As has been evident, the vast body of welfare state scholarship primarily focuses on the influence that institutions and their leaders have had on the creation of the divided welfare state. In the case of the United Steelworkers of America and its turn to private welfare security the history has yet to be fully developed. Although much has been written about Philip Murray and the postwar political realities that influenced the union's decision to bargain for private security, Murray has been somewhat mischaracterized as unconcerned about the rank and file. Moreover, the literature fails to fully address internal union dynamics in regard to the issue of long-term welfare security, dynamics that grew out of steelworkers' long struggle against the inadequacies of security and working conditions provided by the weak welfare capitalism of the steel industry.

\section{Welfare Capitalism in Steel}

The second industrial revolution arising in the last quarter of the nineteenth century brought with it enormous change for the American worker. Heavy industry relied on large labor forces, ever-changing productive technologies, and new labor-management relationships. The rise of large-scale industry challenged workers on numerous levels often producing labormanagement conflict. These conflicts were witnessed throughout the late nineteenth and early twentieth centuries; conflicts such as the labor uprising of 1877, the Haymarket riot of 1886, the Homestead Steel strike of 1892, and the Pullman strike of 1894 just to name a few. The labor

\footnotetext{
${ }^{21}$ See Alan Derickson, “The United Steelworkers of America and Health Insurance, 1937-1962” in Sally M. Miller and Daniel A. Cornford ed., American Labor in the Era of World War II (West Port: Praeger, 1995).
} 
unrest associated with the late nineteenth century and early twentieth century ultimately collided with new scientific approaches to production and workforce management, and a new crop of industrial leadership emanating from the legal and accounting professions. These factors became foundational in the development of the labor-management philosophy known today as welfare capitalism. $^{22}$

There is not one definitive definition for welfare capitalism due to its non-standard policies, which varied from industry to industry and company to company. Instead, to understand welfare capitalism one has to look for generalities across its spectrum. Beginning in the late nineteenth century and taking firm root in the twentieth century, welfare capitalism in its various forms was a new, and less openly hostile tool for capital to manage large and diverse workforces laboring in hazardous work environments for meager wages. The US steel industry is the exemplar par excellence for offering workers poor wages and poor working conditions in this time period. For instance, in 1907 muckraking journalist William Hard, writing for Everybody's Magazine, exposed the horrific working conditions of steelworkers in South Chicago. His reporting revealed that in 1906 at US Steel's South Chicago mill 52 steelworkers had lost their lives and an estimated 552 workers received disabling injuries. ${ }^{23}$ Also, up until 1923, steelworkers worked what was known as the "long-turn," which amounted to a standard 12-hour work day, 6 to 7 days a week, and a 24-hour shift every two weeks as the day and night shifts revolved. As novelist Thomas Bell wrote in Out of this Furnace, a story about three generations of Pittsburgh Steelworkers, “at three o'clock in the morning of a long turn a man

\footnotetext{
${ }^{22}$ David Brody, Workers in Industrial America: Essays on the Twentieth Century Struggle, 2nd ed. (Oxford University Press, USA, 1993), 48-78.

${ }^{23}$ William Hard, “Making Steel and Killing Men” Everybody’s Magazine, November 1907.
} 
could die without knowing it." ${ }^{24}$ Indeed, life as a steelworker was difficult and extremely dangerous. Moreover, workers in steel often faced a managerial cohort that was arbitrary in its decision-making process and regularly abusive of the power they inherently wielded over nonunionized workers.

The early twentieth-century steel mill, before the rise of the CIO and SWOC, was indeed an authoritarian bastion of capitalist hegemony, semi-feudal in nature, and absent any semblance of a democratic voice for the worker. Needless to say, conditions such as these produced a profoundly conflictual relationship between workers and management often leading to labor unrest. Labor-management conflict, and the associated consequences of it, for instance, high labor turnover or disruptions in a steel mill's efficiency and productivity, negatively impacted the corporation's profitability. Consequently, many industrialists by the turn of the twentieth century began instituting welfare capitalist programs as an alternative labor management strategy to the traditional conflict-ridden model.

Some industries began offering workers incentives such as stock options in the company, financial services to help workers purchase a home, company sponsored housing developments, recreational facilities for children, company sponsored medical treatment, group insurance plans, pension plans, workplace safety programs, and even Employee Representation Plans (ERPs). On the surface, these benefits look innocuous and almost benevolent; however, under the surface, they were tools of control. Welfare capitalism strove to win the hearts and minds of an often conflict-ridden and resentful workforce; giving workers a better quality of life at home and in the workplace. And with the introduction of ERP's, welfare capitalism halfheartedly gave workers a superficial sense of workplace democracy, fairness, and justice. Indeed, these programs

\footnotetext{
24 Thomas Bell and David P. Demarest, Out of This Furnace: A Novel of Immigrant Labor in America, 1 edition (Pittsburgh: University of Pittsburgh Press, 1976), 167.
} 
appeared to mark a stark break with the more hardline labor management policies of the past, but no matter how beneficial or benevolent welfare capitalism seemed, at its core, it bolstered managerial hegemony. Welfare capitalist programs thus tied a worker's security, stability, and overall betterment to the needs of employers, especially the continued profitability of the company. Anti-company activity, such as striking, forming unions, or promoting particular political philosophies became less attractive to the average worker. Historian David Brody notes that rhetorically, "employers of the 1920s explained their labor policies as an expression of right conduct and as an effort to raise industrial efficiency." 25 Beyond these goals, Brody notes a more critical class objective built into the welfare capitalist strategy. In Workers in Industrial America: Essays on the Twentieth Century Struggle, he points to the writings of economist Sumner H. Slichter who suggested that welfare capitalist schemes were "to prevent him [the worker] from becoming class conscious and from organizing trade unions." ${ }^{26}$

By the 1920s, welfare capitalist plans dotted the industrial landscape. For instance, by 1928 over 6 million industrial workers were covered by some form of group social insurance valued at $\$ 7.5$ billion. In 1928 , over 350 companies offered their workers some type of pension plan. By 1927, over 800,000 workers were invested in company stock. The American steel industry was deeply involved in welfare capitalist practices before the Great Depression. For instance, by the 1920s, the Youngstown Sheet and Tube company had a robust welfare capitalist plan, which included an ERP. Moreover, "U.S. Steel's expenditures [on welfare programs] averaged over ten million dollars a year in the 1920s." ${ }^{27}$ Indeed, throughout American industry welfare capitalism had strong roots, and by and large, worked to diminish class conflict

\footnotetext{
${ }^{25}$ Brody, Workers in Industrial America, 57.

${ }^{26}$ Brody, 57.

${ }^{27}$ Brody, 54-55.
} 
throughout much of the roaring twenties. However, in order for welfare capitalism to thrive and to achieve the class-oriented outcomes industrialist so desired, it needed one thing: continued economic growth and prosperity. As Brody shows, the Great Depression, beginning in October 1929, pulled the rug out from underneath welfare capitalism and the acquiescent and compliant workforce it had generated. The depression ensured that industry could no longer divert capital to welfare capitalist programs and many programs withered away. ${ }^{28}$

Brody's insights and analysis of welfare capitalism go beyond previous scholarship. Indeed, Brody argues that those scholars who previously studied the topic characterized welfare capitalism as some peculiar outlier of history that achieved no significant legacy. Brody argues otherwise. His argument touches on an often-overlooked variable in the welfare capitalist equation: the average worker. Brody suggests that welfare capitalist programs actually appealed to average workers. That ultimately, the bulk of average steelworkers were less interested in and or motivated by various political ideologies, and instead, were very motivated by access to comfort, stability, and security, and readily willing to accept the dominant social relationships of capitalist production if that system could produce those desired conditions. Thus, Brody argues that the contempt workers expressed for welfare capitalism in the depths of the depression era were not motivated by anti-capitalist notions or a deep seeded hatred of paternalistic corporations. Rather, Brody concludes that if the Great Depression never materialized workers might very well have continued to accept welfare capitalism indefinitely. ${ }^{29}$

David Brody's essay on steelworkers and welfare capitalism is the wellspring from which this dissertation seeks to build upon. His analysis of welfare capitalism prior to the Great Depression highlights that most steelworkers were not revolutionaries and generally accepted the

\footnotetext{
${ }^{28}$ Brody, 66.

${ }^{29}$ Brody, 78.
} 
privatized social programs of their employer. Indeed, over the course of the Great Depression, World War II, and the immediate postwar era, thousands of steelworkers were purchasing their own social insurance, and many were still connected to welfare capitalism through the often poor and inadequate company pension system. Less acquainted and familiar were steelworkers to the federal social insurance system, and due to the fact that the social security system did not immediately impact the active worker's life outside of the payroll tax, some rank-and-file steelworkers were skeptical of the efficacy of public welfare even into the war period.

Throughout the Great Depression and World War II, USWA leaders believed in the efficacy of public welfare and pushed for the expansion of the public welfare state, seen for instance, in the USWA's support for the Wagner-Murray-Dingell Bill. However, as time moved forward, the political feasibility of passing such a bill diminished in the early postwar years. Moreover, in 1946, steel employers arbitrarily began to force steelworkers to retire at the age of 65. The retiree crisis that followed made the rank-and-file more vocal as to the urgency of bargaining for long-term welfare security. Within the USWA, many rank-and-file steelworkers pushed their leaders to use the full economic power of the Steelworker's union to win strong pensions and social insurance at the bargaining table that would give steelworkers the long-term economic and welfare security they desired as well as help to alleviate the plight of forced retired steelworkers. Moreover, steelworkers stressed that any program of welfare benefits bargained for by the union needed to eliminate the arbitrary power and control that employers traditionally wielded over private benefit systems.

Rather than accept the USWA's private welfare demands, the steel industry vehemently fought them precisely because the Steelworker's agenda looked to undermine the rationale behind welfare capitalist control. Rather than being a tool of manipulation, the steel industry 
viewed a more democratized system of welfare benefits as a long-term threat both to the managerial rights of employers and future profitability. Consequently, it took a major strike in 1949 before the steel industry was forced to accept the union's welfare security demands. Although successful in establishing private welfare security in 1949, and expanding and improving the plan throughout the 1950s, the union's turn toward private welfare security would ultimately help to exacerbate the growth of the country's public/private welfare state. Moreover, by the end of the 1950s, the Steelworker's indemnity based social insurance program would find itself plagued by rampant medical cost inflation eating into the wage gains of steelworkers. Thus, by 1960, after a two-year study of the union's pension and social insurance system, the USWA concluded that the indemnity-based model of social insurance was a flawed and inadequate method of providing welfare security, and the union began to open itself up to the possibility of bargaining for alternative forms of social insurance, preferring the Kaiser Foundation Health Plan model to the indemnity insurance model.

An in-depth and comprehensive study of the USWA and its turn to private welfare security reveals a couple of significant insights. First, much of the current scholarship on the USWA paints the union as very disconnected from the wants, needs, and desires of the union's rank-and-file members. It is true that the union's structure was multilayered and extensively controlled and influenced by Philip Murray and the USWA International Executive Board (IEB). However, this study finds that union leaders from Philip Murray, to his staff, to the USWA district directors, were intimately aware of the wants, needs, and desires of rank-and-file steelworkers, and generally responsive to their demands, especially in the realm of wages, pensions, and social insurance. 
Second, this dissertation adds another element to the complex history of the development of the public/private welfare state in the United States. Indeed, USWA leaders faced a changing political climate during the war and postwar eras that did influence the union's decision to bargaining for private welfare security. However, politics was not the only consideration or issue pushing the union in the direction of private welfare. Rather, steelworkers had a long connection to private welfare benefits in the form of welfare capitalism and in purchasing their own private forms of insurance coverage. In addition, the retiree crises that developed in 1946 after many steel firms began forcing steelworkers to retire at age 65 , made the rank-and-file more vocal about bargaining for security and made the issue of security a more pressing and immediate concern for USWA leaders. Thus, with the possibility of expanding Social Security and passing national healthcare forestalled by the rise of conservative politics, and given the urgency associated with the retiree crises, the union in 1946 began to focus intently on studying the possibilities of private pensions and social insurance and developing strategies for winning long-term welfare security at the bargaining table.

Third, the USWA's bid to win employer provided pensions and social insurance in 1949 marked a significant turning point in how the nation viewed the role of the employer in the longterm care and security of American workers. This change can be witnessed in the ruling submitted by President Truman's Fact-Finding Board created to mediate the 1949 steel strike. In that report, the public, as represented by those members of the Fact-Finding Board, found in favor of the union's argument that in leu of a National Health Care System, employers had a responsibility to invest in the long-term care and security of American workers. Although the Fact-Finding Board had no binding authority to enforce its ruling, the board's finding highlighted the general public's sentiment regarding the issue of who is responsible for the security of 
American workers, and was a clarion call to labor to bring the Fact-Finding Board's ruling to fruition via the process of collective bargaining, and if need be the mobilization of the union's economic power through a strike. This ruling in 1949, and the subsequent mobilization of labor to secure long-term security at the bargaining table, is significant in light of the current state of health care and retirement today. Beginning in the 1970s and continuing up to today, employers have persistently tried to shed their social obligation to provide their workers with health and retirement security. This trend has even infected the public sector as states with diminishing budgets have increasingly reneged on their contractual obligations or have sought concessionary cuts to their health and retirement programs.

Lastly, many histories on the war period and the immediate postwar period have discussed Philip Murray as a labor leader, however, no significant study has been made of Murray during World War II and up to his death in November 1952. This dissertation is not specifically focused on Philip Murray; however, he is undoubtedly a significant presence within this overall work. Earlier histories have often portrayed Murray as somewhat conservative, domineering, and very attached to a labor ideology that advocated Tripartism into the postwar era. To some degree Murray does fit into these categories; however, Murray is more complex. This dissertation thus finds Murray to be pragmatic, calculating, and very concerned with the public's perception of labor. Moreover, Murray, a man who held firm convictions and beliefs about how the USWA should operate, was also malleable and subject to changing his position based on the concerns of the rank-and-file, his staff, and his district leaders. Murray was also heavily influenced by Catholic social thought as well as his experience with the labor movement after World War I, which proved to be a disaster for the American labor movement. In addition, Murray was a stalwart believer in American democracy although he understood American 
democracy, and many of the institutions of American government, to be flawed. Consequently, Murray argued for what he called the "original responsibility" of labor, which advocated unionism built on strength through size and solidarity, a strong reliance on collective bargaining, and Keynesian macro-economic control and regulation of the economy. The USWA's IEB records show that although Murray tried to use the wartime state to advance the labor movement, over the course of the war Murray and other union leaders became weary of tripartite boards such as the NWLB and eschewed them moving into the immediate postwar era.

It can be argued that the above attributes made Philip Murray one of the finest labor leaders in American history, who ultimately led the USWA to unprecedented heights by 1952, vastly improving the material conditions of steelworkers and to a degree all workers throughout the country. From our present-day perspective with the labor movement a shell of its former self, the USWA model, although hierarchical and bureaucratic, might seem to some a model that needs to be reinvigorated. There is indeed something to be said for robust industrial unionism built on the shear economic power derived from size and solidarity. Murray and the steelworker's union, at least for a brief moment in the sun, used that model effectively against large steel corporations, thus securing a larger share of the value produced by steelworkers. However, Murray and the majority of steelworkers from the district level on down to the lowest job-class rank-and-filer, never truly challenged the structural foundation of capitalism, choosing instead, to rely on the economic power of the union to ameliorate the myriad negative social and economic problems associated with unrestrained capitalism. For a period of time this strategy worked; however, not challenging the structural foundation of capitalism ensured that a small minority of capitalist stake holders would make the key investment decisions that impacted the lives of countless workers, their families, and their communities. Leaving these key decisions in 
the hands of the steel industry would eventually come to haunt the USWA and the larger labor movement throughout the last quarter of the twentieth century all the way up to the present day. Murray's strength through size unionism was a powerful strategy that bettered the lives of industrial workers but in the long run proved feeble in the face deindustrialization, technological change, and offshoring, which turned once thriving industrial communities such as Youngstown, Ohio and Detroit, Michigan into industrial wastelands. In the years ahead we have to learn from our history and find new ways in which workers and their unions can obtain a legitimate and effective voice in the corporate board room or go even further and eliminate the structural inequalities of capitalist class relations through, for instance, worker owned and operated enterprises on the Mondragon coop model.

This study relies heavily on USWA International Executive Board records (IEB). The USWA IEB was established at the first USWA convention held in 1942. According to the 1942 constitution, the IEB "shall enforce the Constitution and carry out the instructions of the International Conventions, and between the International Conventions shall have power to direct the affairs of the International Union."30 The IEB was composed of the USWA President, the Secretary-Treasurer, two presidential assistants, all district directors, and the director of Canada. According to the constitution, the IEB was mandated to meet at least two times a year; however, under the presidencies of Philip Murray and David McDonald, the board consistently met more than twice a year especially in times of crisis or leading up to or during important union events such as a strike. ${ }^{31}$ For example, from 1958 to 1960, an intense period associated with the 1959 steel strike, the USWA IEB met a total of 20 times. $^{32}$

\footnotetext{
${ }^{30}$ Constitution of the International Union, United Steelworkers of America CIO, adopted at Cleveland, Ohio May $22,1942,12-13$.

${ }^{31}$ Ibid.

${ }^{32}$ Lloyd Ulman, The Government of the Steel Workers' Union (New York: John Wiley and Sons, Inc. 1962), 121.
} 
Using the USWA IEB record has proven significant in a number of ways. First, very little has been written about the USWA during WWII and the immediate postwar era. The USWA IEB in this period was very active and the IEB record provides critical insight into the union's decision-making process. Second, the IEB record is very transparent and offers open and frank discussions of critical issues and events such as the 1944 wage case, the 1946 steel strike, the 1949 steel strike, and the 1959 steel strike. Not only does the IEB record reveal how union leaders thought and acted during critical periods, it also provides us insight into the thought process of union leaders, from executive officers to district directors, and through the process of inference, the IEB reveals to a lesser degree the demands of rank-and-file members on union leadership. Lastly, the USWA IEB provides a window into the mind of Philip Murray. Murray is prominently featured in the IEB. Reading the IEB thus reveals Murray's thought process and rationale behind his actions during this important era of labor history. Although scholars have found limited primary source material from which to construct a biography of Murray similar to those written on Walter Reuther and John L. Lewis, the IEB does reveal in detail how Philip Murray navigated the tumultuous eras of World War II and the immediate postwar period.

\section{Chapter Overview}

Chapter 2 charts the USWA's quest for security during World War II. Operating within the confines of the wartime state, the USWA and its President, Philip Murray, attempted to use the exigencies of war to promote a progressive postwar agenda and to make the USWA a large, powerful, and permanent institution in American society. Initially, the Steelworkers pushed vigorously in 1943 for the enactment of a national healthcare system in the form of the WagnerMurray-Dingell bill; however, the bill failed to pass Congress. In leu of the Wagner-Murray- 
Dingell bill the Steelworkers looked to the National War Labor Board (NWLB) to give their members much-needed wage increases due to wartime wage restrictions as well as an employer provided pension and social insurance system. The USWA's 1944 wage case marked the union's first attempt to secure private long-term pensions and social insurance benefits in steel, which also sought to challenge the arbitrary and paternalistic nature of steel industry welfare capitalism. Although successful in wining many provisions of their 24-point wage program, the NWLB ultimately denied the union a wage increase and failed to order the steel industry to develop a pension and social insurance system in line with the union's demands. Both of these issues would take on added urgency in the immediate postwar era.

Chapter 3 focuses on the postwar reconversion era and the 1946 steel strike. As the war neared completion, Philip Murray continued to promote a progressive postwar agenda that included securing wage increases, passing a robust Full Employment bill, enacting national healthcare, and bargaining with the steel industry for the establishment of an annual wage. In addition, he sought to build a cooperative labor-management relationship with enlightened employers, but also vowed to use the full economic power of the Steelworkers union against employers who remained combative and uncooperative. As the war ended, the steel industry outside of a few firms, looked to reassert their managerial prerogative, lobbied to eliminate OPA price controls, and fought the steelworkers' demand for a postwar wage increase. The growing tensions over the aforementioned issues devolved into the 1946 steel strike. In the end, the economic power of the steelworkers won the day, providing much needed wage gains for USWA members. Although victorious in 1946, the wave of industrial strikes throughout 1945 and 1946 invited public scrutiny of labor, opening the door for conservatives to secure control of Congress in November 1946. The 1946 steel strike thus highlights the enormous economic power wielded 
by the USWA and many other labor unions, but also the limits of labor's political power in the postwar era.

Chapter 4 focuses on the USWA's quest for long-term security, which became more immediate and acute after the start of the postwar retiree crises. Beginning in 1946 many steel producers began arbitrarily retiring steelworkers at the age of 65 , eliminating their only real source of income. These retirees often had to rely on inadequate welfare capitalist pensions, and a less than subsistence level Social Security payment. Given these horrible conditions, retirees and active rank-and-file steelworkers made demands on their leaders to bargain for better forms of pensions and social insurance as well as to fight to end the arbitrary and paternalistic nature of welfare capitalism. Throughout the immediate postwar period, USWA leaders pushed once again for a national healthcare system, but their efforts foundered on the back of an upsurge in conservative politics and anti-unionism as well as issues surrounding postwar anti-communism. Although the union sought to win a pension and social insurance system in their 1944 wage case, the 1946 retiree crises intensified that effort. In response to the retiree crises, the union began to intently study the issues of private pensions and social insurance and took steps toward bargaining for security in 1947 and 1948. However, numerous factors, such as the fear of public backlash over further strike activity, 1946 contract restrictions, issues surrounding the legal status of pensions and social insurance vis-à-vis collective bargaining, and an intensified antiunion political climate, all limited the union's ability to bargain for security in 1947 and 1948. The union would have to wait until 1949 before it could mobilize its economic power to win pensions and social insurance at the bargaining table.

Chapter 5 focuses specifically on the USWA and the 1949 steel strike over pensions and social insurance. After much intense study and strategizing, the union demanded from the steel 
industry a comprehensive pension and social insurance system that would offer prepaid care, be paid for entirely by the industry, and allow for a union voice over the program's administration. As was the case in 1944, the steel industry refused to accept the union's demands. Fearing the potential negative national economic ramifications of a steel strike, President Truman intervened in the dispute and established a National Fact-Finding Committee. After hearing testimony of both parties, the committee ultimately ruled in the favor of the USWA for the establishment of a comprehensive system of employer provided pensions and social insurance on a noncontributory basis for steelworkers. Despite the favorable ruling the steel industry refused to accept the board's finding. The strike was vigorously supported by rank and file steelworkers, which ultimately proved valuable in the face of persistent steel industry intransigence. As the strike wore on, Bethlehem Steel eventually broke ranks with other basic steel companies and signed a contract with the USWA. Soon after, the rest of the steel industry followed. The new contract, however, fell short of the union's original demands, in particular its demand for the steel industry to pay for the entire program.

Lastly, chapter 6 looks at the growth and evolution of the Steelworker's pension and social insurance plans throughout the 1950s. Although successful in its 1949 bid to win pensions and social insurance, the 1949 program was deficient on a number of levels. In particular the social insurance program was not entirely paid for by the company, it lacked certain provisions such as dental and eye care, and it failed to control medical costs. Pushed by the rank-and-file to address these deficiencies, and further constrained by a conservative political environment with no hope of passing national healthcare, union leaders worked over the course of the 1950s to bargain for improvements to the 1949 pension and social insurance plan. Moreover, as the retiree population expanded throughout the 1950s, the union began to establish programs to 
address specific retiree issues as well as provide social and recreational opportunities for retired steelworkers. The effort to overcome the deficiencies of the 1949 program culminated in the 1959 steel strike, where rank-and-file steelworkers stood in absolute solidarity for 116-days to defeat the concessionary demands of the industry. The USWA proved victorious in the strike ultimately protecting section 2-B of the contract governing local work rules while also winning a non-contributory social insurance program. The USWA's pension and social insurance improvements won at the bargaining table over the course of the 1950s did better the lives of steelworkers but at the same time more fully solidified the growth and permanence of the public/private welfare state. Moreover, the indemnity insurance model that the USWA social insurance program was built on could not adequately control medical costs and by 1960 the steelworkers gradually came to the realization that indemnity forms of insurance coverage were flawed and insufficient. 


\section{Chapter 2: WWII and the USWA's Quest for Security}

\section{Introduction:}

On Sunday morning, December 7, 1941 at Pearl Harbor, Hawaii, U.S. sailors and marines, many still asleep in their racks, were awakened by a surprise Japanese air attack. The attack killed thousands and destroyed a large portion of the pacific fleet. Moreover, the events of December 7, 1941 unsettled the nation's defensive posture and ignited a spark that propelled the country into its second world war in twenty years. Like World War I before it, the country quickly transitioned to a wartime footing, which significantly impacted the nation's social, political, and economic fabric. The development of the wartime state posed both significant challenges and unimagined possibilities for the CIO, its leaders, and the various industrial unions under the CIO umbrella, especially the United Steelworkers of America (USWA).

Philip Murray and the USWA entered the war era with a cooperative and patriotic spirit determined to do their part to destroy "totalitarianism." At the same time, Murray hoped to use the exigencies of war - particularly the increased power of the wartime state, combined with the burgeoning political power of an ever-growing membership base - to better the lives of not only USWA members but also the working masses in general. Inchoate at first, Murray's vision for the labor movement, and the USWA, gradually evolved as the war progressed, shaped by a number of factors: Murray's pre-war labor philosophy, the political power of the CIO, vacillating social and economic conditions throughout the war, the USWA's desire to achieve security for its members, rank and file wildcat strike activity, public sentiment toward labor, and Murry’s Social Catholic sensibilities. Consequently, these factors influenced Murray's decision (backed by USWA Executive board approval) in late 1943 to put before the steel industry, and eventually the NWLB, a far reaching and well-crafted wage case that not only called for badly 
needed wage increases given the nation's inability to stabilize prices, but also marked the USWA's first attempt to establish a private social insurance system that challenged paternalistic welfare capitalism. Furthermore, the 24 demands of the 1944 wage case went beyond mere bread and butter issues, and instead, sought to lay the foundation for a more progressive postwar America. Although the USWA attempted to win a private pension and social insurance program in its 1944 wage case, over the remaining years of the war and into the early postwar era, Murray and other high-ranking USWA officials never abandoned the goal of passing robust public social insurance in the form of the Wagner-Murray-Dingell bill. Indeed, the union had supported congressional efforts to strengthen social security from its inception. Unfortunately, due in great part to the lack of labor's political power, combined with the emerging security needs of its membership, the USWA and other CIO unions failed in their bid to bring a comprehensive public healthcare system to the masses and thus turned to private alternatives.

\section{Development of the Wartime State}

A fundamental key to success in all wars is a nation's ability to produce goods to sustain the population at home and to defeat enemies abroad. Thus, at the start of WWII, FDR had to develop a means by which conflicts inherent between labor and management could be limited, or at the very least, mediated to ensure non-stop wartime production. To do this, the federal government sought the full cooperation of both business and labor. Shortly after Pearl Harbor, the President called a joint labor-management conference on December 17, 1941 to discuss the wartime labor-management relationship and the imperative of non-stop wartime production. At 
the conference labor declared its intent not to strike for the duration of the war. Management, too, gave its word not to conduct any labor lockouts during the war period. ${ }^{1}$

To help mediate wartime labor-management disputes, on January 12, 1942, the President issued Executive order 9017 establishing the National War Labor Board (NWLB). The order stated, "the national interest demands that there shall be no interruption of any work which contributes to the effective prosecution of the war."2 The NWLB was thus designed to adjudicate wartime labor disputes in a "peaceful" manner allowing for uninhibited wartime production. Like the National Defense Mediation Board (NDMB) before it, the NWLB fell under the Office for Emergency Management and was a tripartite institution. The board was composed of 12 members; 4 representing the public, and 4 members each representing employers and labor. The board was the final authority for wartime labor-management issues, and it had the power to decide wartime labor disputes using, "mediation, voluntary arbitration, or arbitration under the rules established by the Board." 3 The creation of the NWLB made the federal government an even greater presence in the labor-management relationship, which had been expanding since the New Deal. ${ }^{4}$

\footnotetext{
${ }^{1}$ Executive Order 9017 Dated January 12, 1942: Establishment of the National War Labor Board, Section B-2 (also B-3 thru B-5), Vol. 2, The Termination Report of the National War Labor Board: Industrial Disputes and Wage Stabilization, January 12, 1942 to December 31, 1945, 49.

${ }^{2}$ Ibid.

${ }^{3}$ Ibid.

${ }^{4}$ For a look at the role of the NWLB see Nelson Lichtenstein, Labor's War at Home: The CIO in World War II (Philadelphia: Temple University Press, 2003), Chapter 5 and Robert H. Zieger, The CIO, 1935-1955 (Chapel Hill: The University of North Carolina Press, 1997), Chapter 7; For an in-depth understanding of the New Deal and its social and economic impact on the United States see Alan Brinkley, The End of Reform : New Deal Liberalism in Recession and War (New York: Alfred A. Knopf, 1995); Roger Biles, A New Deal for the American People (DeKalb: Northern Illinois University Press, 1991); Steve Fraser and Gary Gerstle, eds., The Rise and Fall of the New Deal Order, 1930-1980 (Princeton: Princeton University Press, 1990); R. Alan Lawson, A Commonwealth of Hope: The New Deal Response to Crisis (Baltimore: Johns Hopkins University Press, 2006); Paul Keith Conkin, The New Deal (New York: Crowell, 1967); Lizabeth Cohen, Making a New Deal: Industrial Workers in Chicago, 1919-1939 (New York: Cambridge University Press, 1990).
} 
For labor, the NWLB was both a hindrance and a useful tool. The creation of the NWLB forced Philip Murray to adjust his philosophy to accommodate the realities of the wartime state. Although slow and cumbersome, especially at the start of the war, over time Murray recognized that the board could secure the institutional permanence of the labor movement by affirming "maintenance of membership" and the "dues check off," as well as bettering the material conditions of workers in the short term. However, to Murray, the most important aspect of the NWLB was its potential to enact the progressive postwar agenda of the CIO.

Beyond controlling labor-management disputes, FDR and the Congress had to take measures to ensure the national economy remained stable during the war. In an effort to legislate wage and price controls, Congress passed the Emergency Price Control Act on January 30, 1942. The act was designed to "further the national defense and security by checking speculative and excessive price rises, price dislocations, and inflationary tendencies, and for other purposes."5 To achieve this, the law called on labor, industry, and merchants, “...to work toward a stabilization of prices, fair and equitable wages, and costs of production." The law specifically spoke to the stabilization of agricultural and other consumer prices as well as rents. ${ }^{6}$ Additionally, the act established the Office of Price Administration (OPA) and gave the OPA the authority to investigate issues relating to prices and rents and sue all parties for violating price controls. $^{7}$

One of the first issues the NWLB had to adjudicate was the longstanding dispute between the USWA and the Little Steel Companies. Ever since the formation of SWOC in 1936, "Little

\footnotetext{
${ }^{5}$ Emergency Price Control Act of 1942 [Public Law 421 - $77^{\text {th }}$ Congress Chapter 26-2D Session H. R. 5990], January 30, 1942, Section B-6, Vol. 2, The Termination Report of the National War Labor Board: Industrial Disputes and Wage Stabilization, January 12, 1942 to December 31, 1945, 51.

${ }^{6}$ Ibid, 52-55.

${ }^{7}$ Ibid, 56.
} 
Steel" companies such as Republic Steel, Youngstown Sheet and Tube, Bethlehem Steel, and Inland Steel, refused to recognize the union. SWOC's strike to organize Little Steel in 1937 ultimately failed; however as the wartime state developed, the lingering dispute between the steelworkers and the Little Steel companies was subsumed under the jurisdiction of the NWLB. ${ }^{8}$ Once the board took over the case, they established a fact-finding panel to investigate the issues. ${ }^{9}$ Hearings began on July 1, 1942, almost a full 6 months after the USWA requested the dispute be taken over by the board. All parties testified before the board to include the fact-finding panel. The steelworkers demanded a \$1.00 an hour wage increase, the "union shop," and the "dues check-off." Industry, however, fiercely contested each demand. With respect to wages, the USWA argued two main points. First, they argued that steelworkers needed a dollar an hour wage increase because unlike other industries producing for the war, steelworkers were not yet receiving abundant overtime opportunities. Second, the steelworkers argued that $\$ 1.00$ an hour was needed to keep pace with inflation. ${ }^{10}$

After testimony concluded, the board made its ruling. Keeping wages in line with inflation was the board's primary concern. Consequently, the board based its wage ruling on the cost of living increase from January 1, 1941 to May 1942, which they calculated to be 15 percent. ${ }^{11}$ The board also took into consideration the Steelworker's wage gains over that same

\footnotetext{
${ }^{8}$ For the definitive history on the rise of the Steelworkers' Organizing Committee (SWOC) see James Douglas Rose, Duquesne and the Rise of Steel Unionism (Urbana: University of Illinois Press, 2001); For the most detailed and comprehensive look at the deadly Little Steel Strike of 1937 see Ahmed White, The Last Great Strike: Little Steel, the CIO, and the Struggle for Labor Rights in New Deal America (Oakland: University of California Press, 2016).

${ }^{9}$ National War Labor Board, Case Nos. 30, 31, 34, 35 In the Matter of Bethlehem Steel Corporation, Republic Steel Corporation, Youngstown Sheet \& Tube Co., Inland Steel Co. and the United Steelworkers of America, C.I. O., formerly known as Steelworkers Organizing Committee, C.I.O., July 16, 1942, Section G-2, Vol. 2, The Termination Report of the National War Labor Board: Industrial Disputes and Wage Stabilization, January 12, 1942 to December 31, 1945, 317.

${ }^{10}$ Ibid, 296, 318.

${ }^{11}$ Ibid, 295.
} 
period, which amounted to 11.8 percent. Thus, the board did not grant the union a 15 percent wage increase, rather, it ruled in favor of a 5.5 percent increase. This increase was composed of 3.2 percent to fill the gap between 15 percent and 11.8 percent as well as a 2.3 percent increase to make up for the higher than average inflation rate plaguing many steel communities. Although not entirely successful on the wage front, the NWLB did grant the union the "dues check off" provision and "maintenance of membership," two crucial provisions needed to secure union permanence and stability given labor's vulnerability under the "no-strike-pledge." 12

For USWA members, the resulting Little Steel formula became a stifling menace as the NWLB held firm to its federal mandate to regulate wages in its part to stabilize the wartime economy. Unfortunately, in other sectors of the economy, the same effort to control prices and profits never materialized leading to inflation. Moreover, employers understood labor's no strike pledge reduced the likelihood that unions would use their economic power during the war. With this knowledge, employers often flouted the contractual grievance machinery. Rank and file steelworkers with legitimate grievances frequently witnessed their grievances fall into an abyss of inaction. Due to the limited effectiveness of the grievance system and the inability to raise wages to keep abreast of inflation, many workers throughout the nation revolted by engaging in periodic wildcat strikes. This issue perplexed USWA leaders who were caught in the catch 22 of labor's "no-strike pledge" and the need to address the concerns of its beleaguered membership. As wildcat strike activity ramped up in the early stages of the war, the union thus became intently focused on limiting wildcat activity, and ultimately, working to overcome the confines of the Little Steel Formula.

\footnotetext{
${ }^{12}$ Robert H. Zieger, The CIO, 1935-1955 (Chapel Hill: The University of North Carolina Press, 1997), 168.
} 


\section{USWA Outlook for the War}

1942 marked the culmination of the Steelworkers Organizing Committee's (SWOC) campaign to organize the "Little Steel" companies. Since 1937 these companies had violently blocked SWOC efforts to organize, even though in that same year, the US Steel Corporation, along with forty-one other steel producers, agreed to sign a contract with SWOC. In May 1942, upon winning contracts with Little Steel, the Steelworkers Organizing Committee officially became the United Steelworkers of America (USWA). Thus, by 1942, the USWA had won the right to represent steelworkers at most steel companies throughout nation, and it was prepared to begin to use its collective power to bargain with the steel industry over issues such as better wages, hours, and working conditions. However, the start of World War II and the subsequent development of the wartime state forced labor to navigate the new social, economic, and political environment wrought by the war. ${ }^{13}$

USWA president Philip Murray viewed the war period as a critical juncture in the history of the United Steelworkers. He saw great opportunities to use the demands associated with the war as a means of solidifying the union's place as a legitimate institution in American society as well as laying the framework for a progressive postwar society. Murray's vision can be seen in his address to the USWA International Executive Board (IEB) in November 1942 where he stated:

Start your drives all over again and build up, build up, and keep building up, because the stronger this organization of ours is during the war, the more potent the organization is going to be down here at the seat of government, and when the war is over, if you have a powerful organization - and I am sure you will - I am very sure you will be in a better position then to join with others in the determination of the course that this old world and

\footnotetext{
${ }^{13}$ United States, Report to the President of the United States on the Labor Dispute in the Basic Steel Industry (Washington: U.S. Govt. Print. Off, 1949), 14-15.
} 
this country of ours should take in the development of a post-war system of planning for the peoples of the universe. ${ }^{14}$

Murray not only viewed the war as an opportunity to solidify the strength of the USWA, he also viewed it as an opportunity to bring "security" to the lives of steelworkers. Thus, before the June 1944 IEB Murry declared, "Every man in this room is hoping that the damned war will finish in a week or two, perhaps tomorrow....That is No. 1. We want to get it out of the way, but in conjunction with our wholesome desire to have the war won speedily is this ever constant, pressing desire to get something out of the war when it does end-a little more security for the people whom we are privileged to represent."15

Murray's motivations and labor philosophy were also deeply rooted in his working-class upbringing and his social catholic religious faith. Philip Murray was born on May 25, 1886 to William and Rose Anne Layden Murray in the Scottish town of Lanarkshire. Young Philip was raised Irish Catholic and spent his early adolescence in a mining community with a strong union tradition. Indeed, Murray's father was the secretary treasurer of the local union. At the tender age of 7, Philip Murray began working in coal mines and was quickly exposed to trade unionist activity. At the age of 16 Murray accompanied his father to America where the family found a new home and mining jobs in the coal fields of western, Pennsylvania. As a young coal miner, Murray's curious and determined mind drove him to expand his education through correspondence courses.

\footnotetext{
14 “'Proceedings of the International Executive Board, United Steelworkers of America,' International Executive Board Meeting, November 17-18, 1942", Box 41, Folder 3, 257-258, United Steelworkers of America, International Executive Board Records, 1940-1973 (1938), Historical Collections and Labor Archives, Special Collections Library, Pennsylvania State University. (Here after abbreviated IEB, date, box, and folder).

${ }^{15}$ IEB, June 13-15, 1944, Box 41, Folder 12, 80.
} 
In just a brief two years from his arrival to the United States, the young coal miner quickly made a name for himself within the United Mine Workers of America. In 1904, Murray challenged the authority of the company when he accused the company's coal weighman of under weighing the coal. The accusation led to a physical altercation between the two men. Moreover, after the scuffle, Murray subsequently demanded that the company use a union check weighman to verify tonnage. In response to Murray's demand, the coal company evicted Murray and his family from company housing and blacklisted him in the community. ${ }^{16}$ Scholars Elizabeth C. Sholes and Thomas E. Leary argue that this incident was a turning point in Murray's life and his consciousness about class relationships and the need for union protection. Indeed, the authors point to a Murray quote in which he professed, "A coal miner has no money. He is alone. He has no organization to defend him. He has nowhere to go...it is not inadequacy of State law. The law is there, but the individual cannot protect himself because he has no organization." 17

From 1905 to 1916, Philip Murray rose meteorically through the ranks of the United Mine Workers of America (UMWA). In 1905, his local union elected him president of the union, and by 1916, with the backing of UMWA president John White as well as John L. Lewis, Murray was elected president of UMWA district $5 .{ }^{18}$ During World War I, Murray also sat on significant wartime boards -- the War Labor Board and the Pennsylvania Regional War Labor Board. Murray also served on the National Bituminous Coal Production Committee. ${ }^{19}$ By 1920,

\footnotetext{
${ }^{16}$ Elizabeth C. Sholes and Thomas E. Leary, "Philip Murray" in Bruce E. Seely ed. Encyclopedia of American Business History and Biography: Iron and Steel in the Twentieth Century (Bruccoli Clark Layman, Inc., and Facts on File, Inc. 1994), 325-326.

${ }^{17} \mathrm{Ibid}, 326$.

${ }^{18}$ Ibid.

${ }^{19}$ Ibid, 326-327.
} 
Murray had ascended to vice president of the UMWA, where he became the union's second in command after its president John L. Lewis. ${ }^{20}$

In 1921, Murray, with the support of the Harding administration, intervened to try and stop the open warfare that had emerged between miners and coal operators in Logan County, West Virginia. Moreover, throughout the difficult decade of the 1920s, Murray worked with John L. Lewis to neutralize socialist factions within the UMWA; however, the two men never saw eye to eye. Sholes and Leary argue that although Murray and Lewis agreed on the trade unionist tenet of collective bargaining, Murray was more open to the intervention of the state in the labor management relationship. ${ }^{21}$ Indeed, from the time Lewis appointed Murray to head the Steelworkers Organizing Committee (SWOC) in 1936 to his death in 1952, the once collegial relationship between Murray and Lewis gradually became acrimonious over political differences as well as differences between how each man viewed the role of the state in the labormanagement process.

Philip Murray was not only shaped by his early introduction to the trade union movement. Through his participation and familiarity with the wartime state during World War I, and his rise through the ranks of the UMWA, he was also heavily influenced by his religious faith. Philip Murray was a follower of a social catholic tradition that developed in the late nineteenth-century from pope Leo XIII's 1891 papal encyclical "Rerum Novarum” (“of New Things"). Rerum Novarum was Leo XIII's attempt to address the multitude of social ills developing in a modern capitalist society. The encyclical argued for a middle path that suggested the church had a role in shaping society away from the materialistic focus of two extremes: laissez-faire capitalism and communism. Rerum Novarum thus argued for (1) the

\footnotetext{
${ }^{20}$ Ibid, 327.
}

${ }^{21}$ Ibid. 
right of private property and the preservation of the family unit, (2) the right of the church to influence social reform (3) that social problems were not the result of economic structure but rather human failure to live ethically and morally, (4) that the state had a duty to preserve "human rights," "individual initiative," and the "common good," (5) that social institutions such as labor unions were a positive tool to better society and (6) that workers had a right to join unions and that the state had a role in protecting workers rights. ${ }^{22}$ Rerum Novarum scholar William Murphy writes that according to social catholic thought, unions, and the association of persons in general, "are formed to work both for the good of their members and for the common good. This means that their proper function is not exhausted once they have attended to the interests of their membership, for those interests must also be measured against the common good." Further noting that in terms of the twentieth century labor movement, "it is not wrong to see Leo XIII's encyclical as one of the major strands in the formation of that movement."23

Beyond Rerum Novarum, Philip Murray was also heavily influenced by Pope Pius XI's 1931 papal encyclical "Quadragesimo Anno" ("Forty Years Having Passed”). Like Leo before him, Pius the XI was writing in the midst of a global depression and the rise of fascism and communism. His encyclical was built on the philosophy of "subsidiarity" and "solidarism," which would provide a "third way" alterative to combat totalitarianism. Subsidiarity argued for the need of state and organizational intervention in society to help ameliorate the social and economic ills that were plaguing society. Thus, according to the encyclical, there was a fundamental relationship between the state and the individual, which could be mediated by non-

\footnotetext{
${ }^{22}$ William Murphy, "In the Beginning Rerum Novarum" in George Weigel and Robert Royal eds., Building the Free Society: Democracy, Capitalism, and Catholic Social Teaching (Washington: Ethics and Public Policy Center, 1993), 15-28.

${ }^{23}$ Murphy, "In the Beginning Rerum Novarum," 28.
} 
government organizations such as labor unions. ${ }^{24}$ On solidarism, encyclical scholar Thomas C. Kohler writes, "repudiating both centrally planned command economies and unrestricted competition, solidarism proposes the establishment of free, voluntary, and self-governing organizations composed of all members of the various professions and occupations represented in the economy." 25 Moreover, the encyclical argued that "the economy is a set of social relations composed of various autonomous vocational organizations that are bound together to achieve the welfare of all." ${ }^{\text {26 }}$ Pius XI's encyclical thus expanded on Leo XIII's argument for the acceptance of labor unions as a necessary tool to combat the social ills of a capitalist society and prevent the spread of totalitarian alternatives such as fascism, communism, and unrestrained laissez-faire capitalism.

As will be evident throughout this text, Philip Murray's life and labor philosophy were heavily influenced by his belief in the Catholic social encyclicals of Leo XIII and Pius XI. Murray's animus toward laissez-faire capitalism as well as the totalitarian extremes of fascism and soviet communism influenced his thoughts and actions as a labor leader throughout the 1930s, World War II, and the immediate postwar era. Understanding the tenants of the papal encyclicals allows us to better understand Murray's actions throughout his tenure as President of the USWA. Ultimately, Murray's social philosophy, steeped in the teachings of Rerum Novarum and Quadragesimo Anno, believed that large and numerically strong unions in conjunction with a regulatory state could offset the power of capital and thwart the rise of totalitarian alternatives. In addition, Murray believed that through moral and ethical action, mutual cooperation, and

\footnotetext{
${ }^{24}$ Thomas C. Kohler, "In praise of Little Platoons: Quadragesimo Anno" in George Weigel and Robert Royal eds., Building the Free Society: Democracy, Capitalism, and Catholic Social Teaching (Washington: Ethics and Public Policy Center, 1993), 32-39.

${ }^{25}$ Kohler, "In praise of Little Platoons: Quadragesimo Anno," 37.

${ }^{26}$ Ibid.
} 
collective bargaining, American society would regain prosperity, and at the same time, preserve democracy and the rights of the individual citizens. ${ }^{27}$

\section{The Steelworkers and the Fight for Public Security}

From its inception in the late 1930s the SWOC, and later the USWA, consistently supported congressional efforts to expand the public welfare system. This can be initially witnessed with the union's support of the social security amendments of the late 1930s, its willingness to participate and testify before boards of inquiry related to bettering the social safety net, and especially its efforts to lobby for the creation of a national healthcare system. Although often concerned with and distracted by wartime issues such as inflation, wildcat strikes, and responding to conservative efforts to weaken the labor movement, the USWA and Philip Murray viewed the war era as an opportunity to build up the federal social safety net. The year 1943 proved a crucial year in that fight, as the Steelworker's vigorously advocated for Congress to pass the Wagner-Murray-Dingle bill (WMD). The effort to pass WMD was intimately tied to debates over US tax policy, and the USWA was deeply involved with the treasury department's effort to promote tax equality and stifle the conservative and less egalitarian tax proposals filtering throughout Congress. Although the USWA's efforts proved unsuccessful, the 1943 fight for WMD and a more equitable tax system highlighted the union's desire to promote a public social safety net not just for its members but for the nation as a whole. Furthermore, the inability of USWA to mobilize enough political power to pass WMD, marked a pragmatic point of departure for the union. Thus, in 1944 the union began for the first time an attempt to secure

\footnotetext{
${ }^{27}$ For a more detailed look at the social catholic tradition and labor, work, and urban life see Kenneth J. Heineman, A Catholic New Deal: Religion and Reform in Depression Pittsburgh (Pennsylvania: Penn State University Press, 2005); Robert Bruno, Justified by Work: Identity and the Meaning of Faith in Chicago's Working-Class Churches, (Columbus: Ohio State University Press, 2008); William Issel, Church and State in the City: Catholics and Politics in Twentieth-Century San Francisco (Philadelphia: Temple University Press, 2012); Saul Bronder, Social Justice and Church Authority: The Public Life of Archbishop Robert E .Lucey (Philadelphia: Temple University Press, 1982).
} 
employer provided pensions and social insurance as seen in its 1944 wage case.

USWA activism on social insurance had earlier roots. In 1938 the CIO was invited to send representatives to testify before the National Health conference held July 18-20, in Washington D.C. Many scholars of public healthcare point to the 1938 conference as a key event in the evolution of healthcare policy. Prior to the conference earlier efforts regarding healthcare reform primarily involved elite groups of social insurance reformers and social insurance experts. However, the Great Depression and the rise of the labor movement now allowed for the voice of workers into the healthcare debate. ${ }^{28}$ Lee Pressmen, the general counsel of both the CIO and the USWA, testified before the committee along with Florence Greenberg of the SWOC's Council of Auxiliaries. Speaking before the committee Pressman noted that he was for a "Federal system of health insurance," arguing against any type of government system of health care at the state level. Furthermore, Pressman attacked what he felt were the nefarious influences of many medical association throughout the country. He told the conference that, "The private agencies that have had control of our health services simply cannot administer the kind of program we contemplate. It is true that doctors of this country have sacrificed their lives, have given considerable effort to perform a public service. I do not criticize the individual doctors. I direct my attack specifically at the upper hierarchy of these medical associations that simply refuses to give adequate health to the people of this country." 29 Pressman concluded his remarks to the

\footnotetext{
${ }^{28}$ For an in-depth analysis of the demographic change in the debate over national healthcare reform see Alan Derickson, Health Security for All: Dreams of Universal Health Care in America, (Baltimore: The Johns Hopkins University Press, 2005), Chapters 3 and 4; Jennifer Klein also points to the 1938 National Health conference as a pivotal turning point in the national debate on healthcare and marks the interjection of voices from below, Jennifer Klein, For All These Rights: Business, Labor, and the Shaping of America's Public-Private Welfare State (Princeton: Princeton University Press, 2003)141-153.

${ }^{29}$ Testimony of Lee Pressman, General Counsel of the CIO and SWOC, The Nation's Health, Discussion at the National Health Conference, July 18, 19, 20, 1938, Washington, D.C., called by the Interdepartmental Committee to Coordinate Health and Welfare Activities, to consider a National Health Program proposed in the Report of the Technical Committee on Medical Care, 63.
} 
conference suggesting that any federal health care system should be funded via direct tax revenues rather than payroll taxes, and he argued against fee for service models of health care delivery. ${ }^{30}$

Florence Greenberg gave a more intimate portrait of the healthcare needs and concerns of average steelworkers. Speaking particularly about health conditions in her home city of Chicago, she declared before the conference that, "I want to show them another picture. I want to show them a sick Chicago....I speak as the representative of the organized wives of workers. My people are asking that our government take health from the list of luxuries to be bought only by money, and add it to the list of 'inalienable rights' of every citizen." ${ }^{\prime 31}$

Mrs. Greenberg recounted the myriad industrial hazards that faced workers on a daily basis. She described how steelworkers experienced extreme climatic environments, especially during the winter months. It was then that steelworkers confronted the intensity of heat from the furnace and rolling mills, combined with the biting cold of the winter months. She thus declared, "No wonder pneumonia is common around the steel mills...."32 Furthermore, she described other harmful aspects of industrial work, for instance, dusty work environments that raised the risk of lung maladies such as silicosis and tuberculosis. Greenberg brought to the attention of the conference the fact that low wage industrial workers often forgo treatment for injury or illness because of their inability to pay for proper medical care. This reality not only affected the wage earner, but, the lack of affordable care also impacted the worker's family, especially children. Moreover, forgoing treatment for fear of debt often led a worker to temporary or even permanent

\footnotetext{
${ }^{30}$ Ibid, 64.

${ }^{31}$ Testimony of Florence Greenberg, Council of Auxiliaries, The Nation's Health, Discussion at the National Health Conference, July 18, 19, 20, 1938, Washington, D.C., called by the Interdepartmental Committee to Coordinate Health and Welfare Activities, to consider a National Health Program proposed in the Report of the Technical Committee on Medical Care, 64-65.

${ }^{32}$ Ibid, 64-65.
} 
disability thus depriving the family its primary source of financial stability. Lastly, Greenberg argued that health conditions for black Chicagoans were even starker noting,

Although the health status of all workers in Chicago is very poor, the health of the Negro worker is especially bad. There is six times as much tuberculosis among Negroes as among white people, and the proportion of other diseases is also very high. Still there is only one overcrowded private hospital to serve the Negro community. Life, it seems, is cheaper in Chicago than hospital beds. ${ }^{33}$

Beyond testifying before boards of inquiry such as the National Health Conference, the $\mathrm{CIO}$ and the USWA consistently passed convention resolutions in favor of the expansion of the nation's social security system. For example, delegates at the 1940 SWOC convention passed resolutions calling for both a better old age pension system rooted at the federal level as well as a resolution calling for a federal healthcare program. The resolution on old age pensions argued that such a program was beneficial to the overall economy and would help boost aggregate demand. Moreover, it argued that such a program should be "administered through a single Federal System" and should be funded "by taxes upon aggregates of wealth and income." ${ }^{34}$ The convention resolution on health called for a federally administered health care program "covering all persons, providing for free medical care for low income groups, cash benefits for temporary disability to workers, and the construction of needed hospitals in rural and urban areas throughout the country." 35 The resolution suggested further that SWOC locals work to establish "general medical cooperatives," which would help "spur" the passage of health legislation. ${ }^{36}$ In 1942, USWA resolution 16 on Social Security called for a similar expansion to the public system of welfare security as put forth at the 1940 convention; however, this time the union used the war

\footnotetext{
${ }^{33}$ Ibid, 65.

${ }^{34}$ Proceedings of the Second International Wage and Policy Convention of the Steelworkers Organizing Committee, Chicago, Illinois, May 14-17, 1940, 179.

${ }^{35}$ Ibid, 178.

${ }^{36}$ Ibid.
} 
emergency as a tool to help justify such legislation. For instance, resolution 16 declared that, "The effective prosecution of the war requires the continuation and expansion of an adequate program for the care of our people against the consequences of unemployment, ill-health and old age." ${ }^{37}$ As a generalization, USWA resolutions conformed closely to those of the CIO. Although these resolutions displayed the USWA's desire to expand the nation's public welfare system, as Martha Derthick shows, by the end of World War II and moving into the early postwar years, CIO resolutions on welfare security began promoting private forms of security through collective bargaining often suggesting that collectively bargained social insurance was a "necessary supplement" to public social security. ${ }^{38}$

Grassroots health and security movements of the late 1930s, like those led by Florence Greenberg in Chicago, combined with institutional support from labor organizations such as the CIO and USWA, worked by the early 1940s to generate a movement in Congress for the expansion of the Social Security system. The product of that movement was WMD. USWA leaders were fully behind the Wagner-Murray-Dingell bill, and believed the expansion of Social Security to be, "one of the basic objectives" of the union and thus gave "its complete support" to the bill. For the USWA, the WMD bill offered more than just an expansion of security for its members, the legislation comported to the ideals of the Atlantic Charter, "which called for the actual realization of Freedom from Want and Freedom from Fear" for all Americans. ${ }^{39}$

\footnotetext{
${ }^{37}$ Proceedings of the First Convention of the United Steelworkers of America 1942, 176.

${ }^{38}$ Martha Derthick, "Policymaking for Social Security" (Washington: The Brookings Institution, 1979), 120; Jennifer Klein also argues that private insurance companies began to see the value of a basic minimum public welfare system such as Social Security, which enabled them to market supplemental private insurance policies to enhance the minimalist public program, Jennifer Klein, For All These Rights: Business, Labor, and the Shaping of America's Public-Private Welfare State (Princeton: Princeton University Press, 2003), 92-94.

${ }^{39}$ IEB, June 22-24, 1943, Box 41, Folder 6, 175-176. Copy of the Atlantic Charter (5-page draft release with FDR's handwritten annotations) found at Franklin Delano Roosevelt Presidential Library and Museum website, http://www.fdrlibrary.marist.edu/aboutfdr/atlanticcharter.html on April 9, 2016.
} 
Efforts to pass the WMD bill were intimately tied to debates over wartime tax policy. As the war progressed so too did the Federal budget. Historian Carolyn C. Jones argues that treasury secretary Henry Morgenthau looked to establish "a new culture of taxpaying" in the US during the war. ${ }^{40}$ Prior to WWII, the income tax had primarily been a "class" oriented tax that impacted only the richest 5 percent of Americans. Indeed, in 1940, out of a total US population of over 130 million, only 7 million Americans paid income taxes. However, as Jones points out, by the close of World War II the number of Americans paying federal income tax rose dramatically to 42 million. ${ }^{41}$ This drastic increase was the product of Morgenthau's effort to create a "mass-based" system of income taxation to help offset US wartime budget deficits. To accomplish this task, Jones argues that Morgenthau pushed forward two "structural changes" to the existing tax system. The first structural change involved making employers responsible for the collection of income taxes owed by wage earners. In essence, this was similar to the "duescheck-off," however, now for federal taxes. Second, Morgenthau advocated for the joint tax return provision that "sought to achieve more uniformity in the ways that married couples were treated for tax purposes, regardless of differences in spouses' legal rights to income under state law." ${ }^{42}$ These structural changes were bolstered by technological advancements in tax collection as well as the expansion of the tax collection bureaucracy. ${ }^{43}$

Morgenthau had to sell these reforms to the American people, and he did this through radio advertisement, and by engaging with "leader groups" throughout society, for instance, the US labor movement, local community groups, and professional groups. He also relied on

\footnotetext{
${ }^{40}$ Carolyn C. Jones, "Mass-Based Income Taxation: Creating a Taxpaying Culture, 1940-1952" in W. Elliot Brownlee eds., Funding the Modern American State, 1941-1995: The Rise and Fall of the Era of Easy Finance (New York: Cambridge University Press, 1996), 108.

${ }^{41}$ Ibid.

${ }^{42}$ Ibid, 128.

${ }^{43}$ Ibid.
} 
treasury officials such as Randolph Paul to meet with groups and organizations to discuss tax policy. ${ }^{44} 1943$ proved a crucial year in this transition, as Morgenthau faced the threat of more conservative tax proposals filtering through Congress, such as conservative efforts to increase the sales tax. He also understood that adding to the average wage worker's tax burden could easily disrupt the war effort as workers already pinched by inflation would be reluctant to pay more taxes without an added incentive. For Morgenthau, the incentive that possibly could persuade the masses to accept "mass-based" tax reform was the Wagner-Murray-Dingell bill. Thus, the argument went, workers would ultimately be more inclined to go along with paying extra taxes if those taxes brought with it expanded benefits in the form of national healthcare and other upgrades to the current social security system.

By the late summer of 1943, Philip Murray requested Morgenthau to send a Treasury representative to the union's September IEB to help educate board members on the current tax debate. ${ }^{45}$ Morgenthau obliged Murray's request and sent General Counsel of the Treasury, Randolph Paul. Of main concern to Morgenthau and the Treasury Department were Congressional proposals to raise the sale tax by 10 to 15 percent. Treasury officials feared the impact of an increased sales tax and sought to stop its implementation. Murray too loathed the proposed sales tax, telling a New York Times reporter that "any form of sales tax, however labeled, must be avoided as a direct threat to workers' health and efficiency and consequently to war production."46 Morgenthau understood the political power that labor unions such as the USWA wielded, at that time representing 900,000 steelworkers nationwide, and thus believed

\footnotetext{
${ }^{44}$ Ibid, 119.

${ }^{45}$ IEB, September 21-23, 1943, Box 41, F7, 49-50.

46 “Murray Demands 'Adequate' Taxes," Special to the New York Times, January 9, 1943, 19.
} 
that the CIO and the USWA could help shape the tax debate. ${ }^{47}$ Murray also understood the power of labor, declaring before the September IEB, "We are perhaps one of the most important segments of American industry, and what we do as an organization, with reference to the prosecution of a tax program, will undoubtedly have an effect upon, not only the members of our Union and their dependents, but also upon other organizations which are affiliated with us."48

Morgenthau's decision to send Paul to the IEB came with risks. The public disclosure of the meeting had the potential of making the treasury department look biased toward the interest of labor over other social groups. Thus, when the September IEB was called to order, both President Murray and Randolph Paul stressed the need to keep the meeting secret. Paul told the board that he feared Congressional backlash from the tax committee if they discovered that he had met with the steelworkers, suggesting, "I have had experience with them and find they are a rather resentful class under the skin." ${ }^{49}$ Murray informed the board that the information presented by Paul was "highly confidential" and that a breach of that confidentiality might ultimately prove "disastrous" to the union and the treasury's efforts to enact a more progressive and socially responsible tax program. ${ }^{50}$

At the start of the IEB session Murray gave the floor to Randolph Paul. Paul described the various methods of tax collection favorable to the US Treasury. For instance, the treasury department was in favor of increasing excise taxes on luxury and semi-luxury consumer items such as transportation, alcohol, and tobacco products. The treasury also favored increasing the estate and gift tax, which when added to the excise tax would yield $2 \frac{1}{2}$ to 3 billion in federal

\footnotetext{
${ }^{47}$ Ibid, 20-23; "Sales Tax Urged by Taft as Need to Stop Inflation," Special to the New York Times, August 24, $1942,1,9$.

${ }^{48}$ Ibid, 23-24.

${ }^{49}$ Ibid, 7.

${ }^{50}$ Ibid, 20, 50 .
} 
revenue. ${ }^{51}$ Next, Paul pivoted to focus on corporate taxes. According to Paul, corporate pre-tax revenue since 1937 had steadily increased, from 6 billion in 1937 to an estimated 23 1/2 billion by the end of 1943. But Paul further commented that corporate taxes "have not kept pace with the increased net earnings of corporations, and something has got to be done about it." 52 Hence, the treasury was in favor of pushing the corporate tax rate up from 40 percent to 50 percent. Such a move would yield an estimated $\$ 13.5$ billion in revenue, leaving corporations after dividend payments, with $\$ 6.5$ billion in retained earnings. ${ }^{53}$ Even though corporate taxes generated the considerable sum of 13.5 billion, Paul, in blunt terms, told the IEB that the Federal government still had to collect a sizable portion of taxes from individual citizens. He declared, "The big money is below five thousand dollars [a year],--certainly below ten thousand dollars [a year],-and that is where we have to go if we want to talk seriously about crippling inflation."54 Thus, without a tax increase of some form on the masses, the federal government was facing a revenue shortfall. The question then became: what individual tax plans could be implemented that would not overburden the lower income American worker?

Paul described two tax options in-line with the treasury's objectives: Option one was a forced savings arrangement that called for an across-the-board income tax increase on all Americans, combined with a graduated reimbursement of a portion of all revenues collected after the successful completion of the war. Option two called for an increase in the income tax rate on people making $\$ 3000$ a year or more, combined with a rise in the payroll tax from 2 percent to 4 percent. ${ }^{55}$ Paul estimated that option one would generate 6.5 to 7 billion dollars, of which

\footnotetext{
51 Ibid, 12-13.

52 Ibid, 14-15.

${ }^{53}$ Ibid, 15, 28; The Corporate tax rate was increased from 31 percent to 40 percent in 1942 according to taxpolicycenter.org.

${ }^{54}$ IEB, September 21-23, 1943, Box 41, F7, 16.

${ }^{55} \$ 3000$ dollars in 1943 is equivalent to $\$ 41,930.77$ in 2016 according to Inflation Calculator 1800-2016, an app by Cal Stephens.
} 
approximately 3 billion dollars would eventually be returned to the tax payers. Option two on the other hand, would generate an estimated 7 to 8 billion dollars in revenue, and would provide the main source of funding for the expansion of public social welfare under the Wagner-MurrayDingell bill. ${ }^{56}$ The treasury department believed that these two tax plans did not overburden any particular group in American society, and that lower income workers would be more amenable to accepting a tax increase if that burden came with tangible benefits.

The issue of increasing taxes on American citizens, especially those in the lower income brackets, concerned USWA leaders tremendously. What, indeed, was the best option amongst what appeared to be no good options? Philip Murray understood that the exigencies of the war had terrifically burdened the working class. The wartime wage freeze along with continued inflation made it extremely difficult for laborers to make ends meet. The situation bewildered Murray as he found it hard to see how steelworkers, “...under their present wage conditions,... are going to be able to absorb or pay more taxes...."

To clarify his points, Paul offered the IEB an example tax scenario. His scenario was based on a tax payer with two dependents who made a yearly salary of $\$ 2,600$. With the payroll tax, then set at 2 percent, the tax payer faced a yearly tax bill of $\$ 191$. If Congress enacted the payroll tax option and increased the payroll tax to 4 percent, that same tax payer was now looking at a $\$ 75$ dollar a year tax increase bringing his total yearly tax bill to $\$ 266$ dollars. Indeed, the payroll tax plan added a tremendous financial burden on those making less than $\$ 3000$ a year; however, Paul again called the board's attention to the fact that under the payroll tax plan the taxpayer would receive a considerable increase in public social welfare protection to

\footnotetext{
${ }^{56}$ IEB, September 21-23, 1943, Box 41, F7, 17-21.

${ }^{57}$ Ibid, 24.
} 
include health coverage. ${ }^{58}$ Paul finished his example scenario declaring, "Now, do you want that, or do you want to put off this Social Security until some other time? If you want it now, you have got to pay for it." ${ }^{\prime 59}$

IEB member Martin J. Walsh responded to Paul's inquiry by emphatically declaring, "they [do] want it now." However, he made the point that many steelworkers across the country would want assurances that their tax dollars would indeed yield strong social benefits that would be there, "...when they reach a certain period of life." ${ }^{60}$ Walsh told Paul directly that he believed some union members were skeptical about the current Social Security system, arguing that steelworkers, “... are paying now for something they are getting very little benefits from...." Still, given his reservations, Walsh believed that the payroll tax option was the best option forward, and that if given the appropriate assurances, steelworkers would support the plan. ${ }^{61}$ Upon the conclusion of Randolph Paul's presentation, President Murray thanked him for his informative remarks and subsequently offered some commentary of his own. Murray summarized the two tax options pending before the board, and he gave his full support to the payroll tax option. He then addressed the board as president of the CIO. He told the board that the CIO had recently decided to support the payroll tax option declaring, "We want it passed, and we do not want it passed next year or in the year $1945 \ldots . .{ }^{\prime 62}$ Although very much in favor of the payroll tax option, Murray did stress to the IEB two other important points of consideration. $\mathrm{He}$ noted that many within the CIO ranks supported the payroll tax option but believed that the proposed payroll tax rate of 4 percent was too high and borderline "extortionate." ${ }^{33}$ The second

\footnotetext{
${ }^{58} \mathrm{Ibid}, 31-32 . \$ 266$ dollars in 1944 is equivalent to \$3,654.61 in 2016 according to Inflation Calculator 1800-2016, an app by Cal Stephens.

${ }^{59}$ IEB, September 21-23, 1943, Box 41, F7, 32.

${ }^{60}$ Ibid.

${ }^{61}$ Ibid.

${ }^{62}$ Ibid, 48.

${ }^{63}$ Ibid, 48-49.
} 
issue of consideration that Murray mentioned was labor's desire to ensure the full implementation of the Wagner-Murray-Dingell bill. He told the board that the CIO did not "want to be traded down the river, that is, we do not want to go on record in favor of imposing a four percent additional tax on ourselves, and then get some other bill." Noting further, "We want the Bill we have decided upon; we must have that Bill; that is absolutely essential." The board met Murray's remarks with an enthusiastic and affirming round of applause. ${ }^{64}$

In October 1943, Murray was invited by the House Ways and Means Committee to testify on the issue of tax policy. After describing in great detail the condition of low income families - those making less than $\$ 2500$ a year-Murray posed a question to the members of the committee declaring,

Mr. Chairman, the problem before your committee is very simple. Do you wish to impose taxes which cut down the food consumption of the families of war workers? Do you wish to impose taxes which will make war workers move because they could not afford to pay the low rent which they are now paying? Do you wish to impose taxes that will prevent the war workers from having even that minimum type of medical care that they now have? Do you wish to impose taxes that will prevent the war workers from buying even the minimum clothing that they now purchase? Do you wish to deny the war workers even that once or twice a month moving picture entertainment? ${ }^{65}$

He concluded his litany of questions, arguing, "That is just what you will do if you impose additional taxes on the low-income groups. That is exactly the blow that will be struck against the war effort if we add to the already serious financial burdens now being borne by the war workers. ${ }^{966}$

\footnotetext{
${ }^{64}$ Ibid, 49.

${ }^{65}$ Statement of Philip Murray, President of the Congress of Industrial Organizations, Washington, D. C., Friday, October 15, 1943. Revenue Revision of 1943, Hearings before the Committee on Ways and Means House of Representatives, Seventy-Eighth Congress First Session on Revenue Revision of 1943, Revised October 4, 5, 6, 7, 8, 11, 12, 13, 14, 15, 16, 18, 19, and 20, 1943, 913. (Hereafter "Statement of Philip Murray, October 15, 1943”) ${ }^{66}$ Ibid.
} 
Murray proceeded to provide the committee with the CIO's demands and recommendations on the tax issue. His arguments were based on (1) the welfare of the nation's workers, particularly the low-income workers; and (2) the war effort, as Murray believed a tax levied on low income workers would be detrimental to the overall war effort. First, Murray declared that workers making $\$ 3000$ or less should not be taxed. Second, he called for an increase on income tax exemption levels; $\$ 750$ for a single worker and $\$ 1,500$ for a married worker, to include $\$ 400$ for each dependent. Third, Murray called for the repeal of the so-called "Victory Tax," which he declared was, "the most shameful and reprehensible tax that has ever been enacted, reaching down to the pocket of the man making \$12 a week regardless of his obligations or dependents." ${ }^{\prime 67}$ Finally, he forcefully declared that the Congress should not consider an increase in the sales tax, as such a tax was regressive and detrimental to the wellbeing of low income workers. "In peacetime a sales tax is vicious enough," Murray professed, "but in wartime, when we are trying to assure our war workers of sufficient funds to maintain themselves, the proposed sales tax levy would be the equivalent of a military defeat." ${ }^{68}$ Murray further demanded that the Congress place into the 1943 tax bill language ensuring that no American citizen be allowed to receive more than $\$ 25,000$ a year after taxes, which he argued would better facilitate the "equality of sacrifice" espoused by the President and other national leaders. ${ }^{69}$

To bolster his proposals, Murray pointed to corporate earnings during the war. He noted that from 1936 to 1939 the Bethlehem Steel Corporation made on average \$19.2 million after

\footnotetext{
${ }^{67}$ Ibid.

68 Ibid.

${ }^{69}$ Ibid, 914; see also Nelson Lichtenstein, Labor's War at Home: The CIO in World War II (Philadelphia: Temple University Press, 2003), Chapter 6; Lichtenstein shows that after business and government thwarted Philip Murray's Industrial Council Plan, which pushed for labor's voice in the wartime industrial decision making process, labor turned toward an "equality of sacrifice" strategy that tried to ensure no class entity unduly profited from the war and the power of the wartime state.
} 
taxes; however, during the war era, particularly the year 1942, Bethlehem made \$38.1 million after taxes. US Steel in the peacetime years of 1936 to 1939 made on average $\$ 45$ million after taxes, and like Bethlehem, had doubled their profits, reaching $\$ 96.8$ million after taxes in $1942 .^{70}$ Murray argued that if Congress allowed corporations to continue to profit excessively during the war they ran the risk of alienating average workers and fomenting dissent, which the Axis powers might use to their advantage. He suggested raising the tax on corporate incomes above $\$ 25,000$ from 40 percent to 55 percent, and that an excess profits tax of 65 percent be enacted affecting all profits in excess of 4 to 5 percent of invested capital. ${ }^{71}$ He also called for the end of "special privileges" in the tax law benefiting high income persons. For instance, he suggested a tax on income derived from "tax-exempt securities" and called for an increase in the "estate and gift tax." 72

Murray ended his comments by calling for the passage of the Wagner-Murray-Dingell bill in conjunction with a tax bill modeled after the recommendations of the CIO. He announced before the committee that "The American people are vitally concerned now with making provision both for the present and the future against the hazards of unemployment, old-age, and ill health." ${ }^{\prime 3}$ He further suggested that unemployment will continue to burden American workers and that a large chunk of the working population did not have the funds necessary to pay medical expenses. Murray conceded that WMD would entail added costs for workers, but suggested workers understood those cost. However, he made it clear that he was not in favor of the current WMD funding scheme, which called for a 5 percent payroll tax increase that had workers paying

\footnotetext{
${ }^{70}$ Statement of Philip Murray, October 15, 1943, 914

${ }^{71}$ Ibid, 915.

${ }^{72}$ Ibid.

${ }^{73}$ Ibid, 915-916.
} 
4 percent and the employer paying 1 percent noting that such a funding plan, "seems to us a most unfair allocation."74

To add weight to his testimony, Murray brought to the hearing Glenn Speelman, a rank and file steelworker from Mansfield, Ohio. The USWA president wanted Speelman to testify on his financial condition and his position on the current tax debate, thus adding an intimate perspective of those laborers fighting the war in the domestic trenches. ${ }^{75}$ In his remarks Speelman described how he and other USWA workers were following the debate about taxes, particularly the proposal by some in Congress to raise taxes on lower income workers. To that point Mr. Speelman declared, "That is strange and bewildering material for us workers to read." 76

Next, Speelman went on to provide the committee with a breakdown of his yearly budget. Speelman had a wife, a three-and-a-half-year-old boy and a one-year-old boy. At the Empire Sheet \& Tin Plate Company in Mansfield, Ohio, Speelman was a "blooming-mill motor inspector." He also had a high school diploma. Speelman made on average $\$ 1.07$ an hour, which also accounted for any overtime work received due to the war necessity. With this average income Speelman made roughly $\$ 2,573.11$ a year, working on average 45.41 hours a week. He calculated that he would spend around $\$ 700$ dollars for the year on food, taking into account the union victory garden and food preservation program of his local union. ${ }^{77} \mathrm{He}$ budgeted \$225 dollars yearly for clothes, \$50 of which was spent on work clothing and protective equipment such as safety shoes not provided by the company. He spent $\$ 28$ dollars a

\footnotetext{
${ }^{74}$ Ibid, 916.

${ }^{75}$ Statement of Glenn Speelman, Member of the United Steelworkers of America, Mansfield, Ohio. Friday, October 15, 1943. Revenue Revision of 1943, Hearings before the Committee on Ways and Means House of Representatives, Seventy-Eighth Congress First Session on Revenue Revision of 1943, Revised October 4, 5, 6, 7, 8, $11,12,13,14,15,16,18,19$, and 20, 1943, 942-944.

76 Ibid, 942.

77 Ibid.
} 
month on rent, which came to $\$ 336$ for the year. He also emphasized that his rent was low because all he could afford was a place in what he termed an "undesirable location."78 Speelman calculated that his energy costs ran him \$205 a year for coal and gas. He budgeted \$50 dollars for the maintenance of household equipment and emphasized that other than a bed for his new born child, the family would not be purchasing new furniture or equipment. His budget also included \$140 dollars a year for medical and dental costs, and \$35 dollars for medical supplies. Other costs such as cigarettes, newspapers and magazines, car maintenance to include insurance, license, and his telephone cost him \$129 a year. Mr. Speelman gave \$36 dollars a year to his church and \$25 to the Red Cross. His budget included \$50 a year for family outings such as "picnics and a moving picture about once every 2 weeks." At a dollar a month, Speelman paid $\$ 12$ a year in union dues, and he spent $\$ 122.12$ on insurance premiums, which included his contributions to Social Security. For the year 1943, Speelman calculated that he had paid $\$ 55.80$ for the Victory Tax, and \$94.80 “withholding tax." For the year 1942 he paid $\$ 43.43$ in income tax. Finally, Speelman noted that his company offered a 10 percent payroll deduction for war bond purchases, to which Speelman contributed $\$ 316.25 .{ }^{79}$ His total costs for a year were $\$ 2,575.40$ and his average yearly income, as stated earlier, was $\$ 2,573.11$. Thus, according to Speelman's calculation, even for the modest living described in his cost accounting, at the close of the year Speelman was $\$ 2.29$ in the hole. Obviously, his wages did not provide any semblance of security as it was a struggle just to maintain a very modest lifestyle without being able to build a savings outside of war bond contributions. ${ }^{80}$ Finally, Speelman told the committee that he

\footnotetext{
78 Ibid, 943.

79 Ibid.

${ }^{80}$ Ibid.
} 
could not fathom the committee voting to increase the tax burden on workers in light of his remarks, and he warned that such an increase could prove harmful to the war effort. ${ }^{81}$

After providing this sobering account of his yearly finances, Speelman declared before the committee, "certainly it cannot be said that I and my family in our expenditures have been adding to the inflationary spiral." He noted that he and his family were sacrificing, and budgeting to meet that sacrifice. "We have limited ourselves to a bare subsistence level," Speelman professed, "trying to maintain ourselves on a basis whereby we can merely live, and I have some food so that I can perform my work at the steel mill." ${ }^{82}$ Arguing further that a tax increase would be an added hardship on him and his family, Speelman suggested that what he needed instead was a wage increase, noting further that on occasion he had to seek temporary high interest loans to make ends meet, and that his present finances were vulnerable to a major health crises within his family. Moreover, Speelman stressed the point that as compared to other steelworkers, he made a higher wage. With that fact in mind he asked the committee, "What about them? How are they supposed to meet their expenses which are the same as mine?" 83 Finally, Speelman raised the issue of fairness during the wartime emergency. He told the committee that many steelworkers, including himself, were disgusted with the profit margins achieved by their employers. In light of those profits, Speelman believed it inappropriate to ask low income groups to bear further the hardship of a tax increase.

Despite his tenuous position in life, Speelman remained steadfast in his support for the nation's war effort, declaring, "We, the steelworkers, have produced and will continue to produce the steel that this Nation needs for its war program. We are anxious that this war be

\footnotetext{
${ }^{81}$ Ibid.

${ }^{82}$ Ibid.

${ }^{83} \mathrm{Ibid}, 943-944$.
} 
over as quickly as possible and we are only too glad to make our contribution toward that end." Stating further, "We Americans simply ask that you in Congress see to it that the burden upon the workers not be increased which would actually tend to destroy our morale and our productive efficiency." ${ }^{84}$ Unfortunately for Glenn Speelman, Philip Murray, and laborers across the country, their effort to pass the WMD bill failed as it never even made it to a vote in Congress. ${ }^{85}$ Unable to pressure Congress to pass WMD, the steelworkers began searching for alternative security options for its members. To do this USWA leaders first looked to break the crippling wage restrictions of the NWLB's Little Steel Formula, and second, to use the NWLB in an effort to win employer provided pensions and social insurance.

\section{Different Approaches: USWA Efforts to Overcome the Little Steel Formula}

The wartime relationship between the rank-and-file and CIO leaders is difficult to ascertain for a number of reasons. Wartime exigencies ignited demographic changes throughout the country. Jim Crow oppression, combined with a weak southern economy, sparked a series of migrations of Southern African-Americans and poor southern whites to industrial centers of the North and West or to a few southern cities engaged in war production, such as Mobile, Alabama. ${ }^{86}$ Many of the migrants came from agricultural backgrounds and possessed only a limited understanding of the world of industrial work and unionization. Due in great part to the

\footnotetext{
${ }^{84}$ Ibid, 944.

${ }^{85}$ Edward D. Berkowitz, America's Welfare State: From Roosevelt to Reagan (Baltimore: Johns Hopkins University Press, 1991), 52.

${ }^{86}$ Bruce Nelson, “Organized Labor and the Struggle for Black Equality in Mobile during World War II," The Journal of American History 80, no. 3 (December 1, 1993): 952-988; for more information on migration see James R. Grossman, Land of Hope: Chicago, Black Southerners, and the Great Migration (Chicago: University of Chicago Press, 1989); James N. Gregory, The Southern Diaspora: How the Great Migrations of Black and White Southerners Transformed America (Chapel Hill: University of North Carolina Press, 2007); Donna Jean Murch, Living for the City: Migration, Education, and the Rise of the Black Panther Party in Oakland, California (Chapel Hill: University of North Carolina Press, 2010); Patricia Sullivan, Days of Hope: Race and Democracy in the New Deal Era (The University of North Carolina Press, 1996); Kimberley L. Phillips, AlabamaNorth: African-American Migrants, Community, and Working-Class Activism in Cleveland, 1915-1945 (Urbana: University of Illinois Press, 1999); William Joe Trotter Jr. and Nell Irvin Painter, eds. The Great Migration in Historical Perspective: New Dimensions of Race, Class, and Gender (Bloomington: Indiana University Press, 1991).
} 
labor movement's ability to win union security provisions in wartime contracts, neophyte industrial workers were compelled to join unions for the first time. Added to this, the wartime labor force had a propensity for job turnover as jobs were prevalent and workers were often searching for better economic opportunities.

These wartime social and demographic realities posed numerous challenges for CIO leaders. Historian Robert Zieger reveals many of the conservative tendencies of the rank-andfile, suggesting that workers often held contradictory positions with regard to wartime strikes. Although the war era was rife with wildcat strike activity Zieger notes, "The same workers who staged angry walkouts disapproved of wartime strikes.” Further writing, “...workers generally and union members more specifically came down heavily in favor of repression of strike activity. ${ }^{" 87}$ These workers commonly supported the two-party political system rather than a third-party alternative, and they gave their full support to the war effort and the commander in chief. Their patriotism was most manifested in their participation in the US war bond drive as CIO members purchased more war bonds than any other social segment in the nation. Public opinion polls of that era also revealed a disconnect between the priorities of CIO leaders and rank-and-file union members. Although both groups agreed on the need for continuous production with limited industrial conflict, other issues generated less consensus. For example, Zieger argues that union leaders, more than the rank-and-file, prioritized the need to combat antiunion legislation such as the Smith-Connolly act. Furthermore, the rank-and-file, unlike their leaders, prioritized the need to eliminate radical and or criminal elements within the union movement. The issue of the dues check-off marked another divisive subject within the wartime labor movement. According to Zieger two thirds of union members did not support the practice.

\footnotetext{
${ }^{87}$ Zieger, The CIO, 162,163.
} 
Also, by 1945, national polling services revealed that the majority of union members did not support the closed shop principle, and many union members advocated for federal regulation and supervision of union affairs. Polling also revealed that only 38 percent of the rank-and-file in the CIO understood wartime wage policy as established through the Little Steel Formula, and only 50 percent called for a change in that policy to allow for wage increases. Finally, with regard to the issue of racial equality, rank and file members often held racial prejudices that ran counter to the stated goals of CIO leaders, and for that matter, the constitutions that governed CIO labor unions. This unsettling fact can be seen in the various racially motivated hate strikes that sprang up all over the country during the course of the war. ${ }^{88}$

Throughout 1943, the USWA as well as many other CIO unions faced an outbreak of “wildcat" (unauthorized) strike activity. Although Murray disliked wildcat strikes, primarily because they broke the union's "no-strike pledge" and worked to erode public support for the labor movement, he nevertheless understood why they occurred, and sympathized to a degree with the workers engaged in them. Murray argued that wildcat strikes were generated by two factors: (1) the complete inability of the Federal government to roll back prices to the September 15, 1942 level as mandated in the Price Control Law of October 1942, and (2) the blatant and egregious efforts of steel industry leaders to willfully disregard the contractual grievance machinery. ${ }^{89}$ Although frustrated by wildcat strikes, Murray never ruled out the possibility of engaging in a wartime strike; however, he viewed the use of a wartime strike only as a weapon of last resort. It is, however, interesting to note that during the interregnum between the failed Little Steel Strike and the start of World War II, Murray promoted a more robust use of militant

\footnotetext{
${ }^{88}$ Zieger, 161-63; see also Beth T. Bates "Double V for Victory" Mobilizes Black Detroit, 1941-1946 in Jeanne Theoharis and Komozi Woodard eds. Freedom North: Black Freedom Struggles Outside the South, 1940-1980 (New York: Palgrave Macmillan, 2003).

${ }^{89}$ IEB, November 8, 1943, Box 41, F9,19-20.
} 
direct action as he believed that local and district level leaders were relying too heavily on NLRB rulings rather than organizing and mobilizing their economic power. In fact, speaking before the 1940 SWOC convention, Murray stringently counseled convention delegates against relying solely on the NLRB declaring, "somehow or other the workers and many of the employees in and around these plants, instead of indulging in ordinary, militant campaigns of organization around the properties say, 'Oh, let's wait and find out what the National Labor Relations Board is going to do and what the courts are going to do,' relying entirely too much upon the Board and not putting enough pep into ourselves." ${ }^{90}$ At first glance this statement might sound hypocritical when juxtaposed to the union's war era policies, especially the union's effort to curb wildcat strike activity, and its effort to achieve its progressive bargaining goals through the NWLB. However, union tactics and policy in 1943, unlike 1940, were circumscribed by the exigencies of war and the wartime state.

A host of factors during the war influenced the USWA's limited tolerance of wildcat strikes. First, the CIO and affiliated unions gave their pledge to the President that they would not strike during the course of the war. This pledge was based on a quid pro quo understanding between labor and government. As mentioned earlier, in return for a 5.5 percent wage increase, maintenance of membership, and the dues check-off under the Little Steel Formula, and with the understanding that the government would stabilize the economy by controlling prices and profits, labor leaders agreed to the no strike pledge. However, by 1943 the only part of the economy that had been stabilized were wages, thus placing a significant burden on the finances of all American workers who steadily witnessed their purchasing power disintegrate in the face of rampant inflation. The USWA's no strike pledge, employer intransigence, and crippling inflation placed

\footnotetext{
${ }^{90}$ Proceedings of the Second International Wage and Policy Convention of the Steelworkers Organizing Committee, Chicago, Illinois, May 14-17, 1940, 100-101.
} 
labor leaders in a difficult position vis-à-vis the needs of their members and their responsibilities to the nation during the war. Union leaders thus feared that continued wildcat strikes would undermine labors' stature with the American public and with the Federal government.

Murray was keenly aware of the necessity of maintaining a positive relationship with the American public, especially given the conservative congressional outcome of 1942. If public support for the labor movement continued to erode, the union not only faced the very real possibility that more anti-labor candidates would be elected to Congress, it also faced the prospect of eroding its favorability with the public members of the tripartite NWLB. This was especially troublesome given that by September 1943 USWA leaders were growing more inclined to reopen contracts and would need the support of the public members of the board. ${ }^{91}$ Moreover, Murray was perceptively aware that the war would soon be entering a deadlier and more intense phase. As of September 1943, the U.S. military had invaded Italy and it was only a matter of time before the U.S. embarked on a full-scale invasion of Europe. "There are a lot of boys living today," Murray announced before the September IEB, “...who...will not be living at Christmas time, no question about that." ${ }^{92}$ Given the inevitable intensification of the American war effort, Murray thus told the board that the public would most certainly not accept strikes, noting, "you are going to have a very intolerant people back home," who are not, “...prepared to reason out grievances with either you or me. ${ }^{93}$ Murray then counseled the board that union leaders needed to stress the use of the grievance procedure and avoid striking, ultimately cautioning them that if strikes persisted it would be difficult for the union, "to retain our prestige." If the public turned against labor, union leaders feared that future wage cases before

\footnotetext{
${ }^{91}$ IEB, September 21-23, 1943, Box 41, F7 \& F8, 357-358.

${ }^{92}$ Ibid, 351 .

${ }^{93}$ Ibid, 352.
} 
the NWLB would be jeopardized, and maybe just as important, the momentum and successes of the American labor movement might be significantly weakened with the passage of "drastic legislation." 94

By the middle of 1943 the USWA and other CIO unions also faced the real threat of labor conscription in the form of the Austin-Wadsworth bill. Political conservatives and anti-labor forces viewed labor conscription as a way to end labor management conflict during the war and to more generally weaken the labor movement. In theory, if Congress passed the bill, all American laborers would be drafted into wartime service and subject to military leadership and direction. In essence, labor conscription would turn American workers into domestic workersoldiers. A domestic draft of labor would thus have a significant impact on the labor movement as the house of labor would no longer be a free institution. Indeed, the possibility of labor conscription troubled Murray greatly, who argued that there was absolutely no need for such legislation given that American labor was producing more than any other wartime nation despite periodic work stoppages. He further argued that no true national emergency existed to justify labor conscription as the allied war effort was stable, progressing, and not in jeopardy. ${ }^{95}$ Murray thus believed that the labor conscription bill was yet another attempt by anti-labor forces in Congress to enervate the labor movement in the name of a wartime emergency. Given their persistence and the lengths anti-labor forces were willing to go, further wildcat activity, Murray declared, "would undoubtedly encourage conscription."96

The social, political, and economic exigencies of the war era truly posed a significant challenge for all members of the USWA. The wartime environment especially disrupted

\footnotetext{
${ }^{94}$ Ibid.

${ }^{95}$ Ibid, 349 .

${ }^{96}$ Ibid.
} 
Murray's labor management philosophy, which was built on a foundation of codified labor rights, strength through numbers, membership solidarity with the policies of elected leaders (the union as a democratic-republic for labor), an emphasis on collective bargaining, cooperation with cooperative employers, militant direct action against uncooperative employers, and holding true to one's word. Although the Little Steel formula's maintenance of membership clause and dues check off provision did allow many unions, including the USWA, to drastically expand their membership rolls and achieve financial solvency during the war, the no strike pledge, which Murray took seriously, ultimately circumscribed the USWA in its ability to fully mobilize the union's economic power in the form of a strike. Moreover, employer dominance of wartime institutions such as the War Production Board (WPB), as well as an increasingly conservative and reactionary Congress, and a NWLB functioning primarily as an institution to limit wage increases, all encumbered Murray's labor management philosophy. Additionally, the NWLB's appellate division according to Lee Pressman had "just simply broken down" as appellate cases often lingered for, "two to six months before you get an answer whether or not the appeal has been granted." ${ }^{97}$ This stark reality incentivized employers to disregard the contractual grievance machinery further frustrating rank and file workers, and further disrupting the relationship between rank and file workers and union leaders. ${ }^{98}$ Beyond the institutional deficiencies of the wartime state, labor leaders also had to navigate the vicissitudes of public opinion, which by 1943, was growing progressively less tolerant of strike activity, especially given the increased intensity of the American war effort.

Beyond wildcat strike activity, 1943 also witnessed a series of publicly prominent UMWA strikes in that union's bid to break what the miner's union saw as the unfairness of the

\footnotetext{
${ }^{97}$ Ibid, 391.

${ }^{98}$ Ibid, 392.
} 
Little Steel Formula. According to Melvin Dubofsky and Warren Van Tine, UMWA President John L. Lewis had issues with government intervention such as the NWLB, which he believed was flawed and favored business over labor. Moreover, Lewis's prestige as a labor leader had been weakened with his ill-advised opposition to Roosevelt's 1940 reelection bid, which led to his abdication as president of the CIO. These factors, along with Lewis's hatred for the Little Steel formula and the growing inflationary pressure on miners, created a playing field from which Lewis could try and reassert himself as a labor leader by challenging the one-sided nature of economic stabilization. ${ }^{99}$ When anthracite miners struck in early 1943 for better wages and over increased union dues, Lewis used the event to his advantage. He did not immediately intervene to end the strike; instead, he allowed the strike to persist in order to judge the public's reaction. After being on strike for a few days, Lewis finally called the miners back to work. Dubofsky and Van Tine argue that, "Lewis, recognizing that the membership had decided the direction it would march, artfully, maneuvered his way to the head of the parade."100

From March 10, 1943 to early November 1943, Lewis began his bid to break the Little Steel formula. ${ }^{101}$ Lewis demanded a two-dollar a day pay raise, increased vacation time, portal to portal pay, and the elimination of occupational charges paid by the miner. ${ }^{102}$ Throughout the fight, Lewis faced employer resistance to his demands (although this diminished over time, particularly with the northern operators), as well as NWLB opposition due to its mission to control wages. Although the NWLB proved flexible on such demands as vacation time and occupational charges, it resisted Lewis's various wage demands. Given these realities, and

\footnotetext{
${ }^{99}$ Melvyn Dubofsky and Warren Van Tine, John L. Lewis: A Biography, Abridged (Champaign: University of Illinois Press, 1986) 302-305.

${ }^{100}$ Dubofsky and Tine, 306.

${ }^{101}$ Dubofsky and Tine, 310.

${ }^{102}$ Dubofsky and Tine, 307.
} 
despite the real potential of losing public favor, Lewis was ultimately willing to break his no strike pledge. What developed over the course of 1943 was a series of demands, counter demands, and strikes as coal operators and the federal government adamant in holding the line on wages, jousted with Lewis in a colossal power struggle. The impasse was finally broken in early November as Lewis and the UMWA's wage policy committee agreed to a deal with Secretary of the Interior, Harold Ickes. In the end Lewis conceded his demand for an $\$ 8.50$ work day and accepted $\$ 8.125 .{ }^{103}$ Lewis's actions over the course of 1943 highlighted one labor strategy to break the Little Steel Formula and secure much needed wage increases for miners struggling to maintain themselves and their families in the face of inflation. His approach marked a strong point of comparison from which to judge the actions of the USWA in its future bid to break the Little Steel formula.

In the days after the Ickes-Lewis deal Philip Murray grew intensely critical of Lewis and the efficacy of the deal. Murray believed that the deal was "nothing but a subtle, hypocritical gesture," that fell short of being a true wage gain for the mineworkers. ${ }^{104} \mathrm{He}$ argued that the deal did not "improve the wage structure of the miner" and was "predicated upon the assumption that coal miners will work an extra hour every day." 105 Murray's harsh criticism of the deal was not the mere bluster of a man now at odds with his mentor; instead, Murray, who had labored in the mines as a youth and who came of age as a labor leader in the UMWA, believed he understood the UMWA from the perspective of a miner. "I do not speak bombastically when I say that I think I know what the miner's agreement is," Murray declared. "I have lived in the industry throughout life and I think I ought to know." 106 He argued further that he believed many of the

\footnotetext{
${ }^{103}$ Dubofsky and Tine, 312-21.

${ }^{104}$ IEB, November 30-December 3, 1943, Box 41, F10, 17-18.

105 Ibid, 18-19.

106 Ibid, 28.
} 
miners felt the same, “... because they understood...that the agreement is very, very temporary in nature, and it has not built for them any kind of a comfortable structure that will afford them greater security in the days to come." 107

Murray deconstructed the UMWA deal before the USWA IEB. He argued that prior to the deal the miners worked a 7-hour day at $\$ 1.00$ an hour, and miners often had the option of working an extra hour for time and a half pay. If the miner worked a 7-hour work day, he thus made $\$ 7.00$ for the day. If on the other hand he worked an 8 -hour work day he was paid $\$ 8.50$, which was comprised of $\$ 1.00$ an hour for the first 7 hours and $\$ 1.50$ time and a half pay for the eighth hour of work. Under the new UMW contract miners were now required to work an 8hour shift at a daily rate of $\$ 8.50$. The same rate under the old contract now with an extension of one hour to the normal work day. ${ }^{108}$

Murray thus believed that any claim by the UMWA that their wage deal truly offered the miners a legitimate and sustainable wage gain was disingenuous. In his opinion, the work schedule associated with the deal was only temporary in that it would eventually lead to overproduction, “wholly contingent upon the country's ability to continue consuming at the rate of approximately 600,000,000 tons per year."109 Overproduction, Murray predicted, would force the miners back to the 7-hour workday, 35-hour work week. If and when that reversion happened, all wage gains associated with the 1943 deal would be nullified; including portal-toportal pay which required the miner to work a 40-hour week before distribution. If his prediction was correct, Murray declared, “the coal digger won't be able to get enough out of travel time pay to buy himself a bag of peanuts." For Murray, the 1943 UMWA wage deal was nothing more

\footnotetext{
${ }^{107}$ Ibid, 29.

${ }^{108}$ Ibid, 19-20.

${ }^{109}$ Ibid, 21.
} 
than "a diabolical lie in the face of the law and the facts." 110 Ultimately, Murray believed the USWA could break the confines of the Little Steel Formula without resorting to the tactics of John L. Lewis. Moreover, he believed the USWA could use the NWLB to lay the framework for a more progressive postwar society.

\section{Envisioning the Future \& Fighting within the System: The Steel Wage Case of 1943/1944}

By the fall of 1943, USWA leaders grew increasingly frustrated with the government's inability to fully enact the president's economic stabilization program. They understood that their members were bearing the brunt of the government's inability to curb prices and profits, and thus felt the only option before them was to reopen contracts to bargain for better wages. The resolution authorizing the union to move forward on reopening contracts thus declared that the USWA,

and its membership have consistently supported a program designed to achieve the stabilization of our national economy through effective price control, rationing, equitable taxation and a stabilization of wages and the effective prosecution of the war. While wages have been frozen, the other portion of the program have been ignored, thereby laying the basis for inflation. As a result of this failure, it has been the workers solely who have borne the increased burdens resulting from these conditions. ${ }^{111}$

According to this rationalization, USWA leaders were not revolting against the idea of economic stabilization, nor were they reopening the contracts out of mere selfishness. Rather, the union had gone out of its way to support every aspect of the war effort and the president's plan for economic stabilization. Unfortunately, from its inception, workers were the only economic segment sacrificing for the greater good as neither prices nor profits had been stabilized. Consequently, the inequity of the stabilization program had to be challenged, and the steelworkers believed they were the union to do it.

\footnotetext{
110 Ibid, 26-27.

${ }^{111}$ IEB, November 8, 1943, Box 41, F9, 25.
} 
The decision to reopen contracts was not done lightly and was discussed in depth by the Executive Board. With the negative publicity generated from the UMWA strike fresh in the public's mind, Murray and the board feared that reopening the contracts might further erode the public's support for the Steelworkers and the labor movement in general. As both the president of the USWA and the CIO, Murray had to consider the necessity of maintaining a positive relationship with the public as anti-union sentiment would bolster the anti-union climate growing in Congress. Beyond the Congress, Murray had to calculate how the public mood might influence the decisions of the NWLB, particularly the public members of that institution. Any union action that ignited public scrutiny, Murray believed, could jeopardize the union's agenda before the board. Moreover, Murray and his officers had to consider the plight of their members. If the union failed to secure either wage or price relief for the rank-and-file, leaders faced the potential of further wildcat activity. ${ }^{112}$ Murray and other union leaders did not ultimately rule out the possibility of a strike; however, they believed that through "logic and intelligent collective bargaining," as well as the solidarity and cooperation of all union members, the union could be successful in their wage case before the NWLB. ${ }^{113}$

Prior to the USWA's decision to reopen contracts, on select occasions the NWLB had deviated from the Little Steel formula, the most prominent being the UMWA deal. In addition, the board had granted wage increases to the Railroad Brotherhoods and to some crucial wartime occupations such as those in the aircraft industry. Furthermore, by 1943 the NWLB had begun to approve requests for benefit increases. For instance, the board granted "an improved vacation system" to the workers of Federal shipping. ${ }^{114}$ Given these precedents, and cognizant of the need

\footnotetext{
112 Ibid, 16-18.

113 IEB, November 30-December 3, 1943, Box 41, F10, 203.

114 IEB, November 8, 1943, Box 41, F9, 16-17; IEB September 21-23, 1943, Box 41, F7 \& F8, 220.
} 
to improve wages for their members, the USWA formulated a wage policy and notified employers and the NWLB of its intention to reopen contracts.

Ambitious from its initial conception, the USWA's 24-point wage policy demanded not only a wage increase, but more importantly, a plan for long-term member security in the form of a guaranteed annual wage, and for the first time, a demand for a company funded pension and social insurance program that allowed for a union voice in its administration. The union also demanded the establishment of a fund to help returning service men, the adjustment of geographical wage differentials, vacations, severance pay, sick leave, and shift differentials just to name a few. ${ }^{115}$ For Murray, the upcoming battle to secure the demands of the 1944 wage policy was nothing short of, "the biggest single undertaking that has ever been tried in the history of collective bargaining in the United States." ${ }^{116}$ Moreover, the USWA leaders at the 1944 convention characterized the 1944 wage program as, “...one of the most complete and vital heretofore considered in the industry. Its adoption will establish a foundation for stable and improved working conditions and labor relations in an industry which constitutes a cornerstone of the country's economic operations." 117

To achieve the herculean goals of the 1944 wage policy, Murray called for the complete cooperation of all union members in their adherence to the proscribed wage program. The call for unity was nothing new to the steelworkers under Murray's leadership. From day one Murray's philosophy stressed the need for one hundred percent cooperation to the policy decisions of the union's democratically elected leaders. Nevertheless, given the various pitfalls

\footnotetext{
${ }^{115}$ National War Labor Board; In the Matter of: Carnegie-Illinois Steel Corporation et al., and the United Steelworkers of America, CIO, December 27, 1943 case No. 13-350-D in National War Labor Board, Case No. 1116230-D-14-1 et al., In Re: United Steelworkers of America and the United States Steel Corporation, et al., Brief Submitted by the United Steelworkers of America to Panel of National War Labor Board, 3.

${ }^{116}$ IEB, November 30-December 3, 1943, Box 41, F10, 211.

${ }^{117}$ Proceedings of the Second Constitutional Convention of the United Steelworkers of America, May 9, 1944, Vol. 1, Cleveland, Ohio, 40.
} 
that lay before the union, Murray's declaration of unity took on added importance. He stressed to the Executive board, "that at no time in the history of the organization since its very beginning was there greater need for absolute unity of purpose and unity of action in every step that is taken by the organization to protect the interests of its members and further the national well-being." 118 This was a remarkable statement given the union's already storied past, which speaks to Murray's understanding of the importance of the 1944 wage case on the lives of not only USWA members but also the lives of workers across the country. Moreover, Murray announced before the board that he would not stomach "weakness" in the middle of what he foresaw as a battle. "Personally," Murray stressed, "I am not going to speak loudly when I say it, but I am not going to be too tolerant of the fellow who becomes weak in the middle of a fight."119

Through its 1944 wage case the union sought to establish a comprehensive pension and social insurance program that would be completely financed by the company and jointly administered. With this demand, the union looked to expand and improve on many of the benefits already offered by steel companies, which were vestiges of the 1920s-welfare capitalism. The USWA thus demanded a life insurance plan including "accidental death and dismemberment insurance" of 75 percent of one year's salary; 13 weeks of disability insurance equal to 75 percent of a worker's weekly earnings; as well as hospitalization and surgical benefits up to 21 days at six dollars a day for each disability, $\$ 50$ for hospital costs, and $\$ 150$ total for surgical costs. ${ }^{120}$ In no way was this demand an acceptance of the philosophy of welfare capitalism. Rather, it marked the first shot in a war to break down a welfare capitalist system in

\footnotetext{
118 Ibid, 10.

119 Ibid, 17.

${ }^{120}$ National War Labor Board, Case No. 111-6230-D-14-1 et al. In Re: United Steelworkers of America and United States Steel Corporation, et al, Brief Submitted by the United Steelworkers of America to Panel of the National War Labor Board, 113,118.
} 
steel that was paternalistic, undemocratic, and did not come close to meeting the long-term security needs of USWA members.

The USWA argued before the board that the cost of such a plan did not violate the NWLB's 5 percent payroll threshold, and that steel producers, awash with revenues from war production, could easily afford such a program, especially given that tax law allowed corporations to write off a large percentage of the expense. The union's research department estimated the cost of life insurance before tax deductions to be $\$ 10.78$ a year per individual worker and \$1.76 a year per individual worker for accidental death and dismemberment insurance. ${ }^{121}$ The union estimated the cost of disability insurance to be $\$ 34.95$ per year per individual worker, \$24 a year per individual worker for Blue Cross hospitalization, and \$6 dollars a year per individual worker for surgical benefits. ${ }^{122}$ The union calculated that the total cost for the company before tax write-offs would be $\$ 77.49$ per year per individual worker. After a dividend deduction of $\$ 7.75$ per worker, and after a tax write off of $\$ 55.79$ for companies in the 80 percent tax bracket, the union argued that employers would be able to subtract $\$ 63.54$ from the overall cost of pension and social insurance program bringing the total cost of the plan to a more palatable $\$ 13.95$ per year per individual worker. ${ }^{123}$

Furthermore, the USWA argued that an employer-provided pension and social insurance plan not only benefitted workers for obvious reasons and worked to promote the realization of FDR's four freedoms, such a plan also benefited the war effort by increasing the overall productivity of the steel industry. Moreover, the union argued that private welfare benefits had been a part of the overall wage structure for many steel companies since the first part of the

\footnotetext{
${ }^{121}$ Ibid.

${ }^{122}$ Ibid, 118.

${ }^{123}$ Ibid.
} 
century. The union did not seek to replicate welfare capitalism, however. They did, however, try to use that history to their advantage to shape the private welfare system in their favor. Unlike the welfare capitalist schemes of the past, the union sought an employer financed social insurance plan that would allow for the union's voice in the administration the plan. ${ }^{124}$ The USWA thus argued that group insurance plans worked to bolster "workers' morale and operating efficiency." ${ }^{125}$ To drive this point home before the board, the union cited of all things a National Association of Manufacturers (NAM) study that praised the benefits of group insurance. The study found that group insurance fostered better labor-management relations and worked to reduce costly turnover and "absenteeism" rates, especially during the war. Lastly, the union argued that private group insurance plans benefitted the employer by working to lower Workmen's Compensation claims and premium rates. ${ }^{126}$ The union not only argued that the employer benefited tremendously from group insurance programs, they used that fact to subsequently argue that the company needed to pay 100 percent of the cost, declaring, "in view of the analysis which demonstrates that these plans are vital cogs in the employer's productive machinery, we respectfully submit that their cost should be recognized fully as a cost of production." 127

In closing their argument, the union pointed to a previous NWLB ruling in the "ElectroDynamic Works" case. In that case, the board granted the establishment of a group insurance plan. Although a smaller industry than steel, the union pointed to three specific points in the ruling. First, that the establishment of group insurance, especially during a period of war, worked to increase employees' morale and lowered employee turnover, thus fostering increased

\footnotetext{
${ }^{124}$ Ibid, 114-116.

125 Ibid, 114-115.

126 Ibid.

${ }^{127}$ Ibid, 117.
} 
efficiency and productivity. Second, the group insurance should be considered an issue of wages and thus subject to collective bargaining. And, third, that because the country had yet to fully achieve economic stabilization, labor had been bearing the brunt of stabilization, whereas the steel industry, considering their tax advantages and war profits, could easily afford to pay for a group pension and social insurance plan. ${ }^{128}$

Frederick H. Knight representing the steel industry before the NWLB, argued against the union's demand for a pension and social insurance plan. His argument was built around five key points. (1) that the union underestimated the cost of a group pension and social insurance program; (2) that war time demographic changes to the labor force created a non-uniform labor pool throughout the industry, which would put some steel producers at a cost disadvantage over others. (3) that group insurance was not a wartime necessity; (4) that group insurance had traditionally never been a bargainable item in steel; and (5) that the NWLB had yet to establish a precedent for imposing group insurance on employers. ${ }^{129}$

Regarding points (1) and (2), Knight told the board that the USWA underestimated the total cost of the program. Rather, the industry estimated the total cost of a comprehensive group insurance system to be on average $\$ 55,300,000$ per year, which came to $\$ 106.51$ per year per employee. ${ }^{130}$ This was considerably more than the union's estimated pre-tax deduction cost of \$77.49 per employee per year. Knight expanded his cost argument even further, bringing race and gender into the cost equation. According to Knight a NWLB ruling in favor of imposing a group insurance plan on the steel industry was "neither 'fair' nor 'equitable,"” as demographic differences within the wartime working population created variable cost structures for steel

\footnotetext{
${ }^{128}$ Ibid, 118-119.

${ }^{129}$ The Steel Case: Industry Statements to the NWLB, Vol II, 1944, 809-850.

${ }^{130} \mathrm{Ibid}, 841$.
} 
producers, thus creating a competitive advantage for some producers over others. ${ }^{131}$ The industry argued that the cost of insurances was a factor of numerous variables such as the "average cost age" of a particular working population, the type of work and its associated hazards, employee individual earnings, as well as the, "experience of the group as measured by the claims which have been paid." 132 Knight expounded further on the last point. For instance, in the area of group sickness and accident insurance Knight declared, "It has been found by experience that the purpose of group accident and sickness insurance is defeated if weekly indemnity is permitted in an amount which encourages and rewards malingering." 133 He went on to note that the insurance industry factored in demographic data into their premium rate calculations. For instance, Knight told the board that premium rates were affected by "the proportion of eligible female and nonCaucasian employees of the group." Knight thus argued that the demographic make-up of a particular steel firm influenced the overall cost structure of insurance premiums offering the following example. He stated,

If the percentage of eligible female and non-Caucasian employees constitutes $11 \%$ or more but less than $21 \%$, the standard rate is increased by $15 \%$. If the percentage is more than $21 \%$ but less than $31 \%$, the standard premium rate is increased by $25 \%$. This extra change increases in steps of at least $10 \%$ for each $11 \%$ increase in the percentage of eligible female and non-Caucasian employees. ${ }^{134}$

Knight thus concluded that "two employers with the same number of employees engaged in the same industry and providing identical accident and health benefits might easily have a variation in the cost of the coverage of at least $25 \%$ to $30 \%$ depending upon the variation in the forgoing factors." 135

\footnotetext{
${ }^{131}$ Ibid, 842 .

132 Ibid, 817.

${ }^{133}$ Ibid.

${ }^{134}$ Ibid, 818.

${ }^{135}$ Ibid, 820 .
} 
The steel producers also believed that group insurance did not constitute something designed to further the war effort. Instead, Knight argued that the USWA effort to secure pensions and social insurance was, "a far reaching uniform post-war plan of group insurance for employees.” As such, Knight believed the union's demand fell outside of NWLB jurisdiction as the board was only, "a temporary war agency created to settle current disputes relating to conditions of employment customarily covered in collective-bargaining agreements and not to grant demands involving long range social experiments producing incalculable obligations in the future." ${ }^{136}$ Furthermore, Knight argued that even though some steel producers offered various types of social insurance to their employees, group social insurance had never been, "customarily included in collective-bargaining agreements. ${ }^{137}$ Knight also pointed to the precedent setting cases already adjudicated by the NWLB, unaware or uncaring, that acknowledging the board's previous rulings on the issue of group insurance, actually undermined the industry's assertion that the issue lay outside of the board's jurisdiction. Nevertheless, many of the board's previous rulings favored industry. For instance, the board denied employee requests to establish group insurance plans at both the Alan Wood Steel Company and the Detroit Steel Company. ${ }^{138}$ Moreover in the "In Re Federal Shipbuilding and Drydock Company" case, the board denied the union's request to convert the company's voluntary insurance plan into a "compulsory" plan. ${ }^{139}$ Finally, in the Strand Baking Company Case, the board denied the union's request to force the company to deduct money from employees' paychecks to pay the employees' Blue Cross Hospitalization plan. ${ }^{140}$

\footnotetext{
136 Ibid, 841.

137 Ibid, 835.

${ }^{138}$ Ibid, 831-833.

139 Ibid, 829-830.

${ }^{140}$ Ibid,830-831.
} 
After both parties finished their arguments, it took the board months to deliberate and finalize their ruling. Finally, in November of 1944, the NWLB ruled in favor of many of the Steelworker's demands. ${ }^{141}$ On the question of wages, the NWLB deferred to the president of the United States by drafting a proposal requesting the president to make a decision on whether or not to grant the Steelworker's request for a 17 cent an hour wage increase. Despite the fact that the union's wage request had yet to be determined, the NWLB did solidify many of the union's fringe benefit requests. The board ruled that if the United Steelworkers and steel employers agreed to the establishment of a pension and social insurance plan via collective bargaining the board would approve it as long as the plan "did not exceed 5 percent of payroll." ${ }^{142}$ However, the board stopped short of ordering employers to establish such a plan. Although this ruling opened the door to the possibility of winning a company provided pension and social insurance plan through collective bargaining in the future, the union viewed the specific ruling as a defeat since as long as the war continued the union had to retain its no strike pledge. Void of their economic power for the duration of the war, the likelihood of employers capitulating to the union's demand for a pension and social insurance program remained infinitesimally low. USWA General Counsel, Lee Pressman, noted before the IEB that many fabricating companies had already established group insurance plans because group plans were relatively inexpensive. Pressman, however, told the board that although this ruling allowed for collective bargaining over group plans without first seeking NWLB approval, it nonetheless probably would not come to fruition in basic steel noting, "...but obviously since the Board won't direct it there is no likelihood of getting it from the larger corporations in the industry." ${ }^{143}$ It must be stressed that the USWA's

\footnotetext{
${ }^{141}$ Nelson Lichtenstein, Labor's War at Home: The CIO in World War II (Philadelphia: Temple University Press, 2003), 211.

${ }^{142}$ Klein, For All These Rights, 2003, 179.

${ }^{143}$ IEB, November 26, 1944, Box 41, Folder 13, 99.
} 
effort to secure employer provided pensions and social insurance was indeed a challenge to the underlying philosophy of welfare capitalism. Under a traditional welfare capitalist plan the employer was the purveyor of benevolence. The employer instituted these plans not out of a deep desire to establish worker security but as a tool of control as well as an enticement to build company loyalty. The USWA's demand for pension and social insurance in their 1944 wage case looked to eradicate employer hegemony over welfare programs. Industry saw this as a challenge to its managerial authority and fought against it before the NWLB. As the quest for security continued into the postwar era, the steel industry would repeatedly fight to prevent the USWA from winning their worker centered security demands.

\section{Conclusion}

Philip Murray saw many positives from the 1944 NWLB ruling, for instance, the union was able to secure more substantial vacation provisions, and it was able to win the ability to bargain with employers over severance pay. There were also improvements made for shift differentials, holidays, maintenance of membership, and geographic wage inequities amounting to roughly a 9 cent an hour increase. ${ }^{144}$ Despite not winning on all issues before the NWLB and given that the President still needed to rule on the union's request for a 17 cent an hour wage increase, Phillip Murray saw victory in the NWLB ruling. At the November 1944 IEB he announced, "These four or five things that the Board has given us in this directive might have taken this organization ten years to get through the process of collective bargaining, and after some long strikes." 145 Thus Murray believed that the USWA could not step backward from the newly established precedent. He went as far as to say to the IEB, "...I am not going to approve a contract that is written up by any representative anywhere in the United States that contains less

\footnotetext{
${ }^{144}$ Ibid, 101-120.

${ }^{145}$ Ibid, 113.
} 
than the amounts suggested, or the means to get that amount, ordered by the National War Labor Board." 146 Van Bittner, argued further that the ruling would change the wage structure from this point forward. He stated to the IEB, "...I do say to you that it is a great victory, a moral victory, and a material victory.... We may not be able to get it all this year, but it is the beginning of a new wage structure that our people can understand, and a wage structure that means money to the members of our union in the steel industry." ${ }^{147}$ Bittner and Philip Murray's statements reveal their pragmatism, built from years of experience dealing with intransigent employers in the mine industry, and now the steel industry. They both understood that the NWLB's decisions secured valuable contract provisions that could have taken years to achieve via pugilistic bargaining and strikes.

Even though the likelihood of securing a group insurance plan during the war was slim, this ruling nevertheless opened the door for bargaining over such plans in the future, and as the political hegemony of labor failed to materialize by the end of the war, and as steelworker's demands for long term financial and health security increased, USWA leaders became more pragmatically focused on winning long-term security for their members through collective bargaining and the mobilization of the unions economic power.

\footnotetext{
${ }^{146}$ Ibid, 118.

${ }^{147}$ Ibid, 128-129.
} 


\section{Chapter 3: Postwar Reconversion and the 1946 Steel Strike.}

The Steelworker's 1944 wage case secured many provisions that might have taken years of labor-management struggle to achieve. As mentioned in the previous chapter, Philip Murray and many in the upper echelons of union leadership, believed that the 1944 wage case was a success, and on March 3, 1945, the union signed a year and a half long contract with the steel industry solidifying the 1944 gains. Despite the bargaining victory, the 1945 contract did not include a wage increase. Rather, the NWLB deferred the wage issue to president Roosevelt. Moreover, the NWLB stipulated that the March $3^{\text {rd }}$ contract could only be reopened over wages if and when there was a change in the National Wage Policy. ${ }^{1}$

With the surrender of Japan in August 1945, the nation looked to revert back to a peacetime footing. In August, the Truman administration amended the national wage policy and thus unlocked the door for the Steelworkers to reopen the March $3^{\text {rd }}$ contract over wages. However, the steel industry refused to bargain with the union and subsequently attempted to publicly paint the union as violators of the 1945 contract. Moreover, efforts to bargain over wages took place in an environment of significant change and flux. FDR's death in April 1945 passed the mantle of leadership to Harry Truman, a relatively obscure politician from Missouri who lacked the political and labor credibility of president Roosevelt. Consequently, by January 1946, government efforts to mediate the ongoing wage dispute between the USWA and the steel industry failed, leading to the 1946 steel strike. The strike officially marked the postwar reemergence of class struggle, tempered briefly by the war itself, and fired the opening salvo in the union's bid to bring both immediate and long-term security to its members.

\footnotetext{
${ }^{1}$ IEB, September 10-12, 1945, Box 42, Folder 5, 21-22.
} 


\section{The USWA and the Labor Management Code}

In the Spring of 1945, Philip Murray began to focus on influencing the postwar labormanagement relationship. Murray understood the end of the war was near and he sought to position the USWA in a more strategic position to react to the possibility of a postwar recession. Before 1945 Murray developed a strong relationship with progressive industrialist Henry Kaiser. Murray liked Kaiser and believed him to be a model industrialist who was in touch with the needs of workers and not solely driven by avaricious pursuits of ever-increasing profit margins. Indeed, at the union's 1944 convention Murray invited Kaiser to speak. At the convention Kaiser described his vision of a cooperative capitalistic postwar society, built upon the belief that labor and management could cooperate and prosper together. His words touched a spark with the convention audience, who gave Kaiser an enthusiastic ovation. ${ }^{2}$

Understanding Kaiser's more enlightened business mindset, Murray reached out to Kaiser to discuss a new idea. Describing his actions before the IEB, Murray noted that he believed it best to try and get out in front of the potential labor-management conflict soon to encapsulate the reconversion and postwar eras. Murray's plan involved the codification of a set of principles to govern the labor-management relationship. Kaiser believed it to be a good plan. However, he informed Murray that he could not spearhead the plan because most industrial leaders at that time believed Kaiser to be an apostate and that if he were involved the effort would go nowhere. ${ }^{3}$ Kaiser advised Murray to contact Eric Johnston of the U.S. Chamber of

\footnotetext{
${ }^{2}$ Proceedings of the Second Constitutional Convention of the United Steelworkers of America, Cleveland, Ohio, May 9, 1944, Volume One, 197-206; for a more detailed understanding of how some in the business community accepting and to a degree supported government intervention into the economy see Robert M. Collins, "Positive Business Responses to the New Deal: The Roots of the Committee for Economic Development, 1933-1942." The Business History Review 52, no. 3 (October 1, 1978): 369-91; for a look at the development of "corporate liberalism" see Kim McQuaid, "Corporate Liberalism in the American Business Community, 1920-1940." The Business History Review 52, no. 3 (October 1, 1978): 342-68.

${ }^{3}$ IEB, May 25-26, 1945, Box 42, Folder 1, 24.
} 
Commerce, which he did. Ultimately, Murray was successful in getting Johnston, along with William Green of the AFL, to discuss the creation of a labor-management code. Murray also reached out to Ira Mosher of the National Association of Manufacturers (NAM) requesting his participation. Mosher told Murray that he would pass the idea on to his constituents and get back to him. In the end, the NAM did not participate and would not endorse the labor-management code developed at the conference. ${ }^{4}$ Indeed, conservative business organizations such as the NAM were not interested in developing a labor-management code of conduct, choosing instead to lobby Congress to pass anti-labor legislation such as Taft-Hartley in 1947 as well as vigorously assert capital's "right to manage" the industrial enterprise without labor's interference. Moreover, conservative business organizations and corporations began a campaign to undo the strength of the American labor movement as well as "sell" the virtues of free enterprise to a public scarred by capitalisms collapse in 1929 and the onset of the Great Depression. ${ }^{5}$

Meetings between Murray, Green, and Johnston began in March 1945. The outcome of the talks was a codified set of labor-management principles developed with the hope that both labor and management would adhere to them in the postwar era. Murray believed the code would result in a more productive, cooperative, and less antagonistic labor-management relationship coming out of the war. The code began by suggesting that postwar prosperity could be foiled if labor and management failed to cooperate. Furthermore, it suggested the following key aspects of that cooperative relationship: (1) it highlighted the necessity for continued and sustained

\footnotetext{
${ }^{4}$ Ibid, 24-27.

${ }^{5}$ On the postwar rise of anti-labor business conservativism, which highlights the lack of a postwar labormanagement truce see Howell J. Harris, The Right to Manage: Industrial Relations Policies of American Business in the 1940s (Madison: University of Wisconsin Press, 1982); Elizabeth A Fones-Wolf, Selling Free Enterprise: The Business Assault on Labor and Liberalism, 1945-60 (Urbana: University of Illinois Press, 1994); Kim Phillips-Fein, Invisible Hands: The Businessmen's Crusade Against the New Deal, (New York: W. W. Norton \& Company, 2010).
} 
postwar "production efficiency and technological advancement;" (2) it reaffirmed the continuance of "private competitive capitalism" and the sacredness of private property and "free choice of action;" (3) it declared management's right-to-manage the enterprise, noting further that "management must be free as well from unnecessary governmental interference or burdensome restrictions;" (4) the code called for the recognition of labor's "fundamental rights... to organize and to engage in collective bargaining," declaring further that labor shall be "free from legislative enactments which would interfere with or discourage these objectives;" (5) the code called for the preservation of "democratic rights" and argued for programs and policies that "protect the individual against the hazards of unemployment, old age, and physical impairments;" (6) the code called for the freeing up of global markets and "assistance" to "devastated or underdeveloped nations." Lastly, (7) the code argued for the creation of an "international security organization." Ultimately, the labor-management code was to be the first step of many to bring labor and management together with the hope of establishing "a national committee...to promote an understanding and sympathetic acceptance of this code of principles and will propose such national policies as will advance the best interests of our nation."6

Although the group was successful in drafting the document, the bulk of the business community represented by NAM detested many of the labor provisions put forth in the code. Murray told the IEB that the NAM basically "vented their spleen" with disapproval for the code. ${ }^{7}$ Recounting his conversation with Mosher, Murray stated that the NAM, in particular, hated the section of the code acknowledging a worker's right to organize and bargain collectively. According to Murray, the NAM believed that that section of the code, "went further than any

\footnotetext{
${ }^{6}$ Ibid, 20-23.
}

${ }^{7}$ Ibid, 27. 
declaration that had ever been made in the history of American business." 8 Furthermore, the NAM denounced the section that promoted worker security. According to Murray, the NAM "took violent exception to another suggestion contained in the proposal which they construed to mean that the United States Chamber of Commerce was supporting improved Social Security, and that under no circumstances could the National Association of Manufacturers give support to the implication that business and labor were going to advance the cause of Social Security in the United States of America."9

After describing the code, and the various reactions to it, Murray counseled the IEB. He noted that the coalition that crafted the code was striving for it to have teeth to establish a more peaceful and productive postwar labor-management relationship. Murray also understood that the code could easily fail, noting that for it to succeed all involved needed to approach the code "in the spirit of good faith," suggesting further that, "if good faith isn't there, then it will fail."10 Lastly, he told the board that the code was not a "utopia," nor did he expect the vested interests to approach it in "good faith." "However," Murray declared, "it does mean that the substantial leaders of American enterprise — we hope —will eventually subscribe to it, and thereby alleviate the recurrence of what transpired in our own country after the last war."11

Murray concluded his remarks by offering a layman's interpretation of the principles laid out in the labor-management code. "If I had to put it in a nutshell," Murray declared, "it means this, that if you don't fight me I am not going to fight you; we will try to work out our common problem in a peaceable way. That is about the beginning and end of it."12 Thus for Philip

\footnotetext{
${ }^{8}$ Ibid, 26.

${ }^{9}$ Ibid, 27.

${ }^{10} \mathrm{Ibid}, 30$.

${ }^{11}$ Ibid, 30-31.

${ }^{12} \mathrm{Ibid}, 32$.
} 
Murray, the code was not an effort to capitulate to the steel industry. The principles outlined in the code, were no different from what Murray and key union leaders such as Clint Golden and Harold Ruttenberg promoted in their late 1930s publication titled the Dynamics of Industrial Democracy. ${ }^{13}$ Although this was the labor-management relationship Murray looked to foster, he was astutely aware that most industrialists were not of the mindset of Henry Kaiser and were posturing to destroy labor. Cooperation was Murray's high ground goal, but Murray was also prepared to meet uncooperative industrialists with the full economic force of the steelworker's union. As Murray stated, the Steelworkers would cooperate with employers who wanted to cooperate, but at the same time fight those who looked to destroy labor. For Murray, conflict in the postwar era was just as plausible as cooperation. Given this context, Murray, in what he termed the "original obligation" of labor, believed the key to postwar success lay in organizational strength. Consequently, in the postwar era, he stressed that the union had to grow its ranks to better defend the interests of the union and workers across the country.

\section{Murray's "Original Responsibility"}

In May 1945, Murray educated the IEB on the various social and economic powers mobilizing to undermine the labor movement. He argued that in the face of such opposition the key to the union's success lay in its numerical strength, and that union organizational strength and solidarity were the heart and soul of union power, not the government. The government, Murray believed, could be an extremely powerful tool; however, at the same time, government could be captured by unfriendly anti-labor forces. In essence, friendly labor governments may come and go, but for Murray, union permanence and success was built on a foundation of numerical strength and solidarity.

\footnotetext{
${ }^{13}$ Clinton S. Golden and Harold J. Ruttenberg, The Dynamics of Industrial Democracy (New York: Harper, 1942).
} 
Murray began his discussion on organizing by pointing to USWA organizational statistics compiled by Harold Ruttenberg, which showed that as of June 1944, the union had 72 percent of the top ten steel producers organized. 72 percent at first glance might seem like a strong statistic; however, this rate varied from producer to producer. Some companies, such as Wheeling Steel had union membership statistics bordering 100 percent, while other companies, for instance, Bethlehem Steel, had below average union membership rates. Murray believed 72 percent was not enough for the union to protect its interests and better the lives of its membership. Instead, he argued that the rate needed to be at least 90 percent. ${ }^{14}$ He stressed further the need for District and local level leaders to avoid complacency and actively organize new members declaring, "I do wish that you would give thought to it and that you would implement your thinking by organizing everybody that is eligible for membership in the organization." 15

To reinforce his clarion-call for more organizing, Murray doffed his professor's cap and offered the board a lengthy but extremely informative lecture on labor, government, the primacy of organizational strength, post-World War I labor history, and the current efforts being made by anti-labor forces to weaken the labor movement. He argued that by and large the government during the New Deal and WWII had worked thus far to advance the labor movement considerably. For instance, Murray noted that the Wagner Act had been incredibly advantageous for labor and was one of many government "instrumentalities" working to help labor's cause. However, he warned the board not to let its guard down and become too complacent in the labor government relationship. "But now," Murray declared, with the coming of VE day:

there is a concerted drive being made in the Federal Congress to emasculate the provisions of the National Labor Relations Act and to give employers certain privileges they do not enjoy under the existing legislation, and now that schemes are being designed

\footnotetext{
${ }^{14}$ IEB, May 25-26, 1945, Box 42, Folder 1, 96-100.

${ }^{15}$ Ibid, 100 .
} 
by anti-labor forces to weaken the position of American labor, it seems to me the time has come for organizations such as this to strengthen their position and make more secure their position in the social and economic life of the nation. To do that we have to add to or build up the numerical strength of this organization. We have to give more attention to building up this organization then we have since the beginning of the war. ${ }^{16}$

Murray's call to organize was in no way a self-interested act looking only to preserve the strength and power of the USWA more so than the greater labor movement. Rather, as CIO president, Murray viewed the steelworkers as the bellwether union in the CIO. In essence, as the USWA went, so went the labor movement. Murray counseled the board noting, "It so happens that this Union of yours is regarded as a pivot around which the entire labor movement of the United States revolves." ${ }^{17}$ Thus his rationalization went if anti-labor forces toppled the USWA, "they will succeed in a very substantial way toward attaining their destructive objectives in many other labor organizations throughout the country." ${ }^{18}$ Murray's words not only highlighted his overall concern for the entire labor movement, but they also showed his very astute awareness of the enemies posturing at labor's gate, looking to strike a blow that would erase the gains labor had made since the 1930s. Murray's analysis of the situation was rooted in the past, particularly his experience as a labor leader at the end of World War I. He argued to the board that had the AFL, "taken advantage of the conditions which prevailed then [after WWI] and propagated full employment, the expansion of markets, reconversion and re-employment and agitated on a community and national basis for these things, many of the dangers which later beset the nation might very well have been averted."19 The past was deeply relevant to Philip Murray and he viewed history as a device to be called upon to help make sense of labor's position and outlook vis-à-vis the current global conflict and its aftermath.

\footnotetext{
${ }^{16}$ Ibid, 101-102.

${ }^{17}$ Ibid, 104.

${ }^{18}$ Ibid.

${ }^{19}$ Ibid, 117.
} 
Murray also spoke about the relationship between labor and government. His discourse emphasized the primacy of union organization over government intervention. "For the past four or five years" Murray announced,

almost every labor organization in the United States has been leaning rather heavily upon government. They were required to do so. Regulations have been fixed by our Federal Congress, implemented by directives issued by the President of the United States, which for all practical purposes, placed labor organizations under the supervision of several governmental agencies. But a terrific fight is under way right now to divest the government of these powers. Success may attend their efforts in this direction. ${ }^{20}$

With this sobering analysis, Murray informed the board that the USWA had to protect itself and work to advance the interests of the membership whether or not the government in power at any given time was friendly or hostile to labor. To do this, Murray emphasized the need to strengthen the numerical power of the union declaring, "the original and prime responsibility of the labor union in helping workers and their families supersedes by far the obligation of government to the workers." 21 Murray the pragmatist, always viewed government as a useful tool for labor, however, he did not believe it to be the most essential tool to advance the agenda of the working-class. Indeed, Murray lauded the country's political institutions; however, at the same time, he remained skeptical of their efficiency and leadership, declaring before the board, "I question that any man in the United States holds any higher in esteem than I do my government but I do not all the time have too much confidence in too many of its agencies." 22 Murray ended his lecture stressing labor's "original obligation." He described the many conversations he had on the topic of labor and government with international labor leaders at an international labor conference he had recently attended in San Francisco. He argued that to a

\footnotetext{
${ }^{20}$ Ibid, 105-106.

${ }^{21}$ Ibid, 110-111.

${ }^{22}$ Ibid, 120-121.
} 
nation, China, England, France, and even Premier Vyacheslav Molotov of the Soviet Union, believed like him in the primacy of the union over government declaring:

And so it is with the United States of America. It does not make any difference how friendly the government may be to workers in the United Sates-workers must come to recognize that it is their prime responsibility to correct all of the evils that visit industry. They are the agents and representatives of the workers, and it is their bounden responsibility, it is their original obligation to see to it that those abuses are properly corrected....Y Your job and my job is to organize everybody in this industry eligible for membership in this organization, to protect what we have and to strengthen our gains through the medium of a mighty labor organization such as the United Steelworkers of America. $^{23}$

Indeed, as World War II came to a close, the steelworkers would come to rely heavily on their economic strength as the Congress became less progressive and more conservative and as antilabor forces pursued a legislative and public relations campaign to weaken the American labor movement.

\section{USWA's Vision for a Full Employment Economy and the Annual Wage}

In the months after the 1944 wage case the Steelworkers continued to promote many of the concepts and ideas put forth in their 1944 wage demands. For instance, long-term welfare security, full employment legislation, and the concept of the annual wage. The Murray-PatmanFull Employment bill working its way through Congress in 1945 was a unique combination of New Deal interventionism and Keynesian economics, designed to ensure full employment in the postwar era. The legislation established a Presidential mandate to monitor the nation's economic health and provide periodic reports to Congress. With accurate, real-time economic analysis in hand, the government could then use various forms of economic intervention to include government provided employment to thwart a recessionary trend. Although the bill called for government employment programs, the Steelworkers understood the bill to be more than "a

\footnotetext{
${ }^{23}$ Ibid, 114-115.
} 
'make work' program." Rather they viewed it as "part of the operation of the whole national economy." 24 The annual wage was a concept that ensured a worker received a base line annual salary even during periods of recession and unemployment. In essence, it was a private sector Keynesian remedy to promote full employment designed as a counterpart to public sector full employment legislation. According to executive board records, the Steelworkers did not have pie in the sky hopes for the Full Employment bill, noting that the bill in and of itself was not to be considered "a cureall." Rather, full employment legislation was merely one tool of many that would help promote a more prosperous postwar economy. For instance, the USWA argued that any Full Employment bill needed to contain a minimum wage increase of at least 65 cents, a government mandate allowing the NWLB to raise wages, and the expansion of the unemployment insurance program. Moreover, without these accompaniments, the steelworkers believed that the effort to establish a full employment economy would "fail." Although these reservations were raised by the executive board, the board gave its unanimous support to the bill. ${ }^{25}$ Unfortunately for the Steelworkers the bill that did pass Congress was very weak and watered down. Historian Robert Zieger describes the final bill noting, "Full employment now became simply a desideratum [requirement], along with avoiding inflation and upholding free enterprise. The creation of the Council of Economic Advisors did acknowledge a federal role in economic performance, but gone was the crusading sense of militant Keynesianism contained" in the original legislation. ${ }^{26}$

\footnotetext{
${ }^{24}$ IEB, July 30-August 4, 1945, Box 42, Folder 4, 278.

${ }^{25}$ Ibid, 278-279.

${ }^{26}$ Robert H. Zieger, The CIO, 1935-1955 (Chapel Hill: University of North Carolina Press, 1995); For a look at New Deal liberalisms evolution from an emphasis on reform to an emphasis on preventing capitalism's ills through fiscal and monetary policy see Alan Brinkley, The End of Reform: New Deal Liberalism in Recession and War (New York: Alfred A. Knopf, 1995).
} 
Accompanying the USWA's desire to pass the Murray-Patman bill was its desire to bargain for the annual wage. The steelworkers initially sought NWLB approval of its request for the annual wage in 1944; however, the NWLB refused to mandate that employers accept it. Rather, the NWLB recommended that the concept of an annual wage be studied by the President. Before FDR's death in April of 1945, he established an Advisory Committee to study the annual wage concept. On the committee were representatives of government, industry, and labor. FDR appointed Philip Murray to head the labor delegation with Chamber of Commerce President, Eric Johnston, representing industry. Additionally, the committee was composed of Albert Goss of the National Farmers Grange, and Anna Rosenberg, who had served in various public offices including the War Manpower Commission.

Upon its formation, the committee quickly established a sub-committee to conduct the formal technical analysis of the annual wage concept. The question of who would head the subcommittee became a point of disagreement, especially between Murray and Johnston. Ultimately, Murray won the contest. In the end, Johnston agreed to accept Arthur Meyer to head the subcommittee along with Murray Latimer. Meyer was a public official who Murray had known since the Little Steel Cases of 1942 and who Murray believed to be sympathetic to labor. ${ }^{27}$ Murray Latimer was a social insurance expert and longtime government official who Philip Murray argued was "an active, sympathetic type citizen, broad gauged, a man of great understanding. ${ }^{28}$ Besides serving on the annual wage sub-committee, Latimer would also play a significant role in the USWA's quest for private pensions and social insurance in 1949 and beyond.

${ }^{27}$ Ibid, 254.

${ }^{28}$ Ibid, 255. 
At the July 1945 IEB, Philip Murray discussed the annual wage concept with board members. He argued that the annual wage was another device that would help mitigate the possibility of a postwar recession. He viewed the annual wage as an augmentation to the full employment bill and/or a private sector alternative if the Murray-Patman bill failed in Congress. Thus, Murray told the board that, "if full employment cannot be given or will not be given, then there should be instituted the guarantee which we are seeking, the guarantee of a minimum annual wage incorporated within the framework of our collective bargaining contracts."29 Murray believed that obtaining the annual wage from the steel industry would be "a long, hard pull, a terrific fight," and that the only chance of success lay in the full mobilization of the union's resources. ${ }^{30}$ Prime among these priorities was the need to educate the general public, telling the board that "each man should perform this particular type of missionary work in his own community." ${ }^{31}$ Although he knew the effort to win an annual wage would be a challenge, Murray remained hopeful. He told the board that thus far he had received a positive public reception for the annual wage concept. Moreover, he noted that many small business owners were amenable to the idea because, according to Murray, small business was traditionally the most vulnerable during a recession, and would thus benefit tremendously from policies such as the annual wage, which along with the full employment bill, sought to promote continuous production and high levels of employment. ${ }^{32}$ Ultimately, with a tempered business cycle, small business could more easily survive and prosper. As the USWA promoted the full employment bill and the annual wage concept in early 1945, the issues of wages, so long capped by the Little

\footnotetext{
${ }^{29} \mathrm{Ibid}, 260$.

${ }^{30}$ Ibid.

${ }^{31}$ Ibid.

${ }^{32}$ Ibid, 263-264.
} 
Steel Formula at the start of the war, became the primary focus of the union as the war came to a close.

In late July 1945, the Steelworkers discovered via a news report that the federal government was planning to amend the national wage policy. On first thought, this revelation might have been welcomed news for an organization that had pushed throughout the war to amend the hated Little Steel Formula and that, with victory on horizon, was beginning to fear the effects of wartime production cutbacks and the looming prospect of high unemployment. Unfortunately for the Steelworkers, the proposed change to the national wage policy was not much of a change at all, and ultimately, unpalatable to the union. ${ }^{33}$

The proposed wage policy would have opened up the ability of labor to bargain with their employers over wages but at the same time restricted employers from using a wage increase as justification to raise prices. Furthermore, the policy said that if and when the government granted a wage increase there would be a six-month waiting period before the increase would take effect. Also, in the event of a bargaining impasse over wages, the new policy did not increase the ability of the NWLB to mandate a wage increase even if the facts supported the claim. Without the authority of the NWLB to grant a justifiable wage increase, and given the continued restriction on price levels the Steelworkers predicted, "the arrogant steel companies are not going to engage in bona fide collective bargaining under such circumstances." ${ }^{14}$ In essence, the proposed change in the national wage policy left the steelworkers in basically the same position as under the old policy - unable to bargain with intransigent employers, confined by their no-strike pledge, and unable to get the NWLB to mandate a wage increase. Meanwhile steelworkers across the country struggled to make ends meet. The USWA hated the new policy,

\footnotetext{
${ }^{33}$ IEB, July 30-August 4, 1945, Box 42, Folder 4, 330-338.
}

${ }^{34}$ Ibid, 334. 
and instead, advocated for a simplified wage policy that would open up bargaining over wages while continuing OPA restriction on prices. However, in the event of a bargaining impasse, the Steelworkers demanded that the government give the NWLB the authority to mandate justifiable wage increases.

Immediately upon discovering the news of the proposed change in national wage policy Philip Murray contacted both Lloyd Garrison and George Taylor of the NWLB to vocalize his displeasure with the proposed policy and requested a face to face meeting. Next, Murray took the matter to the IEB to obtain board approval of the union's opposition to the wage policy. Murray had already gone on record as president of the CIO against the proposed wage policy. ${ }^{35}$ He briefed the board on the situation and described his conversation with Lloyd Garrison. Murray noted that he "took occasion to remind him [Garrison] this morning that the Steelworkers Executive Board intended to adopt a resolution condemning the Public Members of the board and criticizing their report, and he asked me if I would withhold publication of this resolution until he and Mr. Taylor had an opportunity to talk to me." ${ }^{36}$ Murray and his officers had already crafted a draft resolution speaking to the wage policy issue, which David McDonald read to the board. The resolution lambasted the persistent failure of the federal government to stabilize the economy while maintaining strict control over wages. As with the union's past arguments about economic stabilization, the resolution made clear the union's disgust with the government's inability to uphold its end of the wartime economic compromise. In a proposed letter to President Truman, drafted with similar language as the pending resolution, the Steelworkers decried the wage freeze imposed by public figures such as Davis, Taylor, and Garrison and argued that, "the result has been a developing restlessness among the wage earners and their fully

\footnotetext{
${ }^{35}$ Ibid.

${ }^{36}$ Ibid, 331-332.
} 
justified resentment that they are suffering from discrimination and shocking unfair treatment at the hands of the public members of the National War Labor Board and the Director of Economic Stabilization." ${ }^{37}$

Indeed, the wartime wage freeze had taken a severe toll on steelworkers. A January 1945 union study of the financial condition of steelworkers in Braddock, Pennsylvania revealed that the average steelworker in Braddock "incurred a deficit of \$11.09 a week." Moreover, this deficit was incurred, "while working long hours, receiving overtime, 'enjoying' a minimum of medical or dental care, no luxuries and horribly poor housing conditions." ${ }^{138}$ In addition, the resolution pointed out that the conditions described above had to be juxtaposed to the wartime profits of industry. According to the USWA, from 1940 to 1944 the steel industry's before tax profits increased 276 percent over the period of 1935 to 1939. During the war, the steel industry made a pretax profit of $\$ 3.5$ billion dollars. When one accounted for the tax bill, the steel industry still came out significantly ahead. The after-tax profit from 1935 to 1939 was $\$ 576$ million compared to the after-tax profit from 1940 to 1944 , which was just over $\$ 1$ billion. ${ }^{39}$

The resolution also placed much of the blame on the public figures charged with managing wartime institutions. It declared that "the total disregard of human needs already proven by public members of the War Labor Board and the Director of Economic Stabilization is again demonstrated," with the proposed wage policy. ${ }^{40}$ Noting further that "This most recent proposal of these men is another demonstration of their shockingly unfair treatment of wage earners as compared to the treatment they have extended to industry." ${ }^{41}$ The resolution was

\footnotetext{
${ }^{37}$ Ibid, 338.

${ }^{38} \mathrm{Ibid}, 333$.

${ }^{39}$ IEB, December 10-12, 1945, Box 42, Folder 7, 67-68.

${ }^{40}$ IEB, July 30-August 4, 1945, Box 42, Folder 4, 334.

${ }^{41}$ Ibid, 335 .
} 
unanimously approved by the IEB. Both the resolution and the letter to Truman would only be made public upon the outcome of Murray's meeting with Garrison and Taylor. ${ }^{42}$ Ultimately, the steelworkers' protest over the proposed change to National Wage Policy lasted only a few weeks because by mid-Aug 1945 the war came to a screeching halt, ushering in reconversion, the last phase of the war on the Homefront.

\section{Post-VJ-Day Reconversion and the 1946 Steel Strike S3 $^{43}$}

In mid-August 1945, the United States unleashed the atomic age when it dropped two atom bombs on the Japanese cities of Hiroshima and Nagasaki. The devastating impact of the weapon caused Japan to reevaluate its desire to continue the war, and on September 2, 1945, the Japanese formally surrendered to General Douglas MacArthur on board the USS Missouri. The surrender of Japan officially brought an end to the world conflict that had taken the lives of over 50 million people and left much of globe in utter devastation. The conclusion of the war was indeed welcomed news for all Americans; however, despite Japan's capitulation, the American homefront witnessed the manifestation of new struggles and the reemergence of old domestic conflicts. The physical war was over, but on the homefront the last phase of the war, reconversion, was just beginning.

Before the war could come to an end at home, with peacetime social and economic conditions restored, the nation had to reconvert from war to peace. The Federal government,

\footnotetext{
${ }^{42}$ Ibid, 338-344.

${ }^{43}$ I am using this title rather than "postwar reconversion" because reconversion according to Harry Truman was still considered a phase of the war. These conditions although in a state of transition influenced and shaped the labormanagement relationship. Consequently, many of the policy proposals offered by the Steelworkers in the reconversion period were designed specifically for reconversion and were not necessarily blanket policies designed to serve the eventual peacetime labor-management relationship. In essence, the USWA sought the reestablishment of "fair" collective bargaining in the peacetime era after reconversion was complete. They believed the NWLB was a defunct institution and were not looking to extend that relationship into the peacetime era. Rather, they first sought to use their collective power to win concessions from industry, and second to translate organizational power into political power to preserve the Wagner act in its traditional form and to expand the welfare state. However, Murray and the Steelworkers did not view the labor government relationship as prime.
} 
including President Truman, viewed reconversion as another phase of the war. Thus, the wartime state persisted throughout the post-VJ-Day period. However, it operated in a state of transition and flux as wartime agencies received new marching orders in an effort to swiftly transition to a peacetime footing. For labor, industry, and government, the reconversion period proved challenging to navigate as competing interests and prolonged frustrations emerged to create at times a very turbulent social and economic environment.

Indeed, each of the three major economic players viewed a successful reconversion in different ways. For the federal government and President Truman, the key to a successful reconversion was the maintenance of high levels of production, and therefore, high rates of employment all the while promoting voluntary cooperation between labor and industry. Industry's reconversion goals differed from both government and labor. Although industry desired to see the maintenance of high levels of production, it also prioritized reasserting its managerial prerogative, amending the Wagner act to weaken labor's power as well as shedding government oversight and regulation, particularly when it came to OPA price controls, and regaining its stature in the eyes of the American public and its workforce. ${ }^{44}$ The CIO, and especially the USWA's goal for reconversion, was to emerge from under the shadow of the NWLB and the hated Little Steel formula, promote worker security via full employment legislation, the annual wage, and the establishment long-term security via an expanded public welfare state augmented by private forms of welfare security. Moreover, the steelworkers sought to reestablish "fair" collective bargaining with the steel industry to obtain immediate economic security in the form of a much-needed wage increase for their members in late 1945 and early 1946.

\footnotetext{
${ }^{44}$ See Harris, The Right to Manage; Fones-Wolf, Selling Free Enterprise.
} 
One of the first transitions from the wartime state came in President Truman's Executive order 9599 issued a few days after VJ-Day. The order promoted a "swift and orderly transition to a peacetime economy of free independent private enterprise with full employment and maximum production in industry and agriculture." ${ }^{\prime 4}$ To accomplish this, the order set out four priorities. First, it called for continued and sustained production throughout the reconversion period. Second, it called for the continuance of OPA regulation and allowed regulators to make "whatever modification in controls over prices, wages, materials and facilities are necessary for an orderly transition from war to peace." Third, it declared the need to open up free collective bargaining as well as ending price controls "as rapidly as possible." Lastly, the order called on both the OPA and the Secretary of Agriculture to monitor prices and use their powers to control inflation. Although controlling inflation was a priority, both the OPA Chairman and the secretary of Agriculture retained the authority to allow price increases on a case by case basis.

In the realm of labor-management relations, the new executive order gave the NWLB authority to open up collective bargaining and accept agreed upon wage increases as long as industry did not use a wage increase as the primary grounds to raise their prices. Finally, the order emphasized that although the combat phase of the war was over the reconversion period was to be considered an extension of wartime conditions. Thus, the order declared:

officials charged with the settlement of labor disputes... shall consider that labor disputes which would interrupt work contributing to the production of military supplies or interfere with effective transition to a peacetime economy are disputes which interrupt work contributing to the effective prosecution of the war. ${ }^{46}$

\footnotetext{
${ }^{45}$ Harry S. Truman: "Executive Order 9599_-Providing for Assistance to Expanded Production and Continued Stabilization of the National Economy During the Transition from War to Peace, and for the Orderly Modification of Wartime Controls Over Prices, Wages, Materials and Facilities," August 18, 1945. Online by Gerhard Peters and John T. Woolley, The American Presidency Project. http://www.presidency.ucsb.edu/ws/?pid=77920.

46 Ibid.
} 
It must be emphasized that the reconversion period was a distinct phase of the war and not an abrupt return to peacetime conditions. Both labor and management faced continued wartime oversight, however, in more malleable forms. Consequently, many of the actions and policies promoted by labor in the period of reconversion were explicitly designed for that distinct wartime phase and were not necessarily designed as a blueprint for the peacetime era.

In the joyous days after Japan's surrender and in the immediate wake of Truman's Executive Order 9599, Murray gathered the executive board together to discuss the wage issue. Prior to the IEB, Murray had been communicating with various levels of the union seeking input and information on the wage issue. Added to these inquiries, Murray also received numerous communications from local unions offering input on wages. ${ }^{47} \mathrm{~A}$ large bulk of the local union communications requested that the union pursue its "demand for an increase of 17 cents per hour." ${ }^{\text {48 }}$ Furthermore, Murray, as CIO president, had been in talks with UAW and UE over how to approach the wage issue during reconversion. Talks with other unions, however, did not prove as fruitful as Murray had hoped: "We tried to get a meeting of minds between the three organizations as to what the general demand ought to be in these industries for wage increases. There did not seem to be any common understanding between the organizations as to the policy." ${ }^{49}$ Some in the UAW were pushing for wage increases as high as 30 percent whereas the USWA and the UE believed the target should be closer to 25 percent, or a $\$ 2.00$ a day increase. ${ }^{50}$ After Murray completed his overview of the situation, he asked the board for its opinion on wages. The majority of directors stated that their membership wanted a $\$ 2.00$ a day (17 cents an hour) increase and the end of the no-strike-pledge. Director James Thomas of District 15

\footnotetext{
${ }^{47}$ IEB, September 10-12, 1945, Box 42, Folder 5, 4-7.

${ }^{48}$ Ibid, 7.

${ }^{49}$ Ibid, 8-9.

${ }^{50} \mathrm{Ibid}, 9$.
} 
stated before the board that, "the feeling of the membership...[was] that the Union had definitely proved its case previously on the 17-cent demand," in their 1944 wage case. ${ }^{51}$ Director Frank Burke of District 16 noted that the "membership wants a $\$ 2.00$ a day increase 'or else'; [meaning the membership] advocates use of economic strength if necessary to obtain the increase." ${ }^{52}$ On a similar note, Director Joseph Goney of District 17 stated that his members were "prepared to go to any length to see it through. ${ }^{, 53}$ And Director Howard Porter of District 24 mentioned that his members generally advocated a $\$ 2.00$ a day increase but were "willing to support the International Union in any policy that may be adopted." 54

Although many directors suggested that the union use its economic power to secure a wage increase if need be, some directors and districts held reservations about economic force. Director William Hart of District 19 wanted a 17 cent an hour increase; however, he suggested "caution should be observed during the reconversion period." ${ }^{55}$ Furthermore, he suggested that the union give "consideration [for] marginal companies whose financial condition will not permit the payment of an increase." 56 Director Henry Burkhammer of District 33 did "not believe a strike would be advisable at this time." Instead, he believed arbitration would be a better approach to achieve the 17-cent increase. ${ }^{57}$ Lastly, Director James Quin of District 26 told the board that his members wanted a 20 to 25 cent an hour increase but that he did not "think the membership would strike very long in support of demands." 58

\footnotetext{
${ }^{51}$ Ibid, 13-14.

${ }^{52}$ Ibid, 14.

${ }^{53}$ Ibid.

${ }^{54}$ Ibid, 16.

${ }^{55}$ Ibid, 14-15.

${ }^{56}$ Ibid.

${ }^{57}$ Ibid, 18.

${ }^{58}$ Ibid, 16.
} 
After the directors finished their comments Murray offered his analysis of the wage situation. He understood that the general attitude of the union was to strike if industry remained intransigent on wage increases. Murray fully understood and recognized the strike sentiment emanating from a large portion of the rank-and-file and he did not shy away from the real possibility of a strike. Indeed, like many other unions, the USWA had renounced its no-strike pledge after VJ day. Still, Murray remained cautious. Being the head of both the CIO and the USWA, Murray had to approach the possibility of a strike from a more strategic perspective. He believed the union should not be impetuous in its sentiment for a strike; rather he argued that initial restraint and rational calculation was needed to put the USWA on the high ground vis-àvis public opinion and national political leadership. Moreover, Murray understood that during the reconversion phase of the war the state would be in a period of flux, which the union had to account for. Thus, Murray informed the board that in the event of a large strike the NWLB would not intervene in the dispute. "To begin with," Murray told the IEB, the NWLB "is a defunct institution--that for all practical purposes it could be of no real service to any labor organization in the United States of America that might become involved in a wage dispute."59 Murray warned that there was an ongoing conflict between the Secretary of Labor and the public members of the NWLB over the role and function of the NWLB in the reconversion period. It was the public members' desire not to take on any new cases during reconversion. Murray went so far as to suggest that "I really believe the National War Labor Board to be a defunct institution. It is dead insofar as its desire to hear new cases is evidenced." 60 Murray then turned his attention to the upcoming Labor Management Conference called by President Truman. The conference according to Murray had the express goal of getting labor

\footnotetext{
${ }^{59}$ IEB, September 10-12, 1945, Box 42, Folder 5, 23-24.

60 Ibid, 24-25.
} 
and management to work toward an "agreement about the processes and machinery that might be utilized for the purpose of serving the interests of both management and workers during this period of reconversion." 61 Furthermore, Murray informed the board that the CIO agenda at the conference was to push an industry acknowledgment of the need for a general wage increase. Beyond that, the $\mathrm{CIO}$ agenda was to call for a raise in the minimum wage to 65 cents an hour, as well as assurance of "no compulsory cooling off periods," and "no compulsory arbitration."62 Lastly, Murray stated that the CIO would use the conference to publicly disseminate that "so far as the no-strike commitment is concerned, it has been withdrawn." ${ }^{63}$

Again Murray cautioned against strike action, especially if the strike would break current contracts. The policy of adhering to the contract was as old as SWOC. For Murray, contracts were to be upheld, which he believed highlighted to the greater public the union's trustworthiness. Furthermore, as anti-union forces continued to expand their economic and political strength in the postwar era, violating a contract could easily be used to paint the labor movement as self-interested, thus giving the movement a black eye before the general public. Murray expressed to the board it was his, "purpose...to respect and honor my obligations." ${ }^{64} \mathrm{He}$, however, did believe in the union's right to strike; but before the union decided to go that route he wanted to ensure the union exhausted all options. Moreover, if and when the union did strike it would strike over wages only, wages being the only contract provision subject to bargaining according to the 1945 contract. For Murray, being thoughtful and strategic was extremely important because if the union jumped to a strike too quickly, "such a decision might very well

\footnotetext{
${ }^{61}$ Ibid, 26.

${ }^{62}$ Ibid, 26-27.

63 Ibid, 27.

64 Ibid, 27.
} 
jeopardize every single, solitary provision of," the March 3, 1945 contract. ${ }^{65}$ Murray argued that the membership needed to be cognizant of the possibility of massive postwar unemployment, estimated by some experts to be near 10 million. If that nightmare scenario manifested, the economic power of the union would diminish exponentially. ${ }^{66}$ Murray thus advised the board to recommend to the USWA Wage Policy Committee that they leave the strike issue open and flexible. A hard and fast policy to strike immediately could have severe negative consequences on the union and the labor movement in general. For Murray, such a belligerent policy "would be accepted by the public and by a great many of our own members as the use of the big stick, that we are going to run around the country, now that V-J Day is over, and club our so-called enemies into a state of economic submission. I think that would be ill advised." ${ }^{" 67} \mathrm{He}$ continued, "I have been through a great many strikes, and I don't run away from them, but I never liked to be blind enough to walk into a strike knowing that I am going to be in a rather delicate situation when I become involved." ${ }^{68} \mathrm{He}$ closed his remarks by suggesting that the board pass a policy stating the union's bargaining goal was 25 cents an hour, which was in line with what the rankand-file was calling for. Moreover, he requested that the resolution provide union leaders and the various steel negotiating committees the flexibility over the strike issue. Ultimately, the board obliged. ${ }^{69}$

In late October 1945, the USWA informed the steel industry of its intent to re-open the March $3^{\text {rd }}$ contract on wages only. The two sides met briefly to discuss the matter; however, it became immediately clear to USWA leaders that the industry was adamant against a wage

\footnotetext{
${ }^{65}$ Ibid, 28.

${ }^{66}$ Ibid, 29.

${ }^{67} \mathrm{Ibid}, 35-36$.

${ }^{68}$ Ibid, 39.

${ }^{69}$ Ibid, 39-40.
} 
increase, especially while they were still subject to OPA price controls. Understanding that the industry was not prepared to negotiate fairly, the USWA broke off negotiations on October 23, 1945, and subsequently called an IEB meeting to discuss a strategy. Although the war was over, the federal government still considered the reconversion period a phase of the war as per executive order 9599, and thus the Smith-Connelly act governed. Given these conditions, the IEB believed it appropriate to seek a strike authorization vote under Smith-Connelly. The IEB wanted the vote in order to gauge the mood of the membership for a strike and also to legitimize the strike in the eyes of the public and the Federal government. A Smith-Connelly authorization vote did not mean the union would immediately strike; as the union could chose when it wanted to call a strike. Thus, the USWA was taking the necessary steps to make any strike legitimate before the law and the general public, and it was telling industry and government that the union was willing to use its economic power to secure much-needed wage gains.

After discussing the issue, David McDonald read the letter requesting the Smith-Connelly strike vote. He declared before the board that, "We are going to walk in there with a letter, reading something like this: 'Gentleman: There is a dispute involving the following companies and the United Steelworkers of America, concerning the issue of wages. Kindly, exercise your good offices under the War Labor Disputes Act, June 25, 1943,... and prepare to take the necessary vote of employees involved according to law."'70 McDonald emphasized the letter's brevity and suggested that he and Lee Pressman would deliver it, "and say, 'Here it is, Gentleman, start Sweating.'"71

Murray viewed the strike authorization vote as a barometer to gauge President Truman's support of labor's demand for increased wages. He believed that once the union submitted the

\footnotetext{
${ }^{70}$ IEB, October 27, 1945, Box 42, Folder 6, 8-9.

${ }^{71}$ Ibid, 9.
} 
request for a strike vote, "the President...in all likelihood, will go on the radio Tuesday, at which time we will know whether he is going to be for us or against us in this campaign for increased wages." ${ }^{72}$ Murray informed the board that he believed that after the strike vote was complete, Truman would use his war powers to intervene in the matter. Furthermore, he reiterated to the board his intent to bring up the wage issue at the Labor Management Conference (LMC).

Before the start of the LMC, and immediately after the USWA submitted its request for a Smith-Connelly strike vote, the Secretary of Labor intervened to try and prevent a labormanagement impasse. The secretary contacted both parties and requested that they immediately resume negotiations. The secretary also appointed Arthur Meyer, Chairman of the New York State Mediation Board, as conciliator in the dispute, and set November $13^{\text {th }}$ as the date for the resumption of bargaining. Murray agreed to the secretary's offer, but on November $7^{\text {th }}$ industry representatives made it clear that they would not consider bargaining with the union until the government eased OPA restrictions or the OPA gave assurances of price relief upon a wage increase. Thus, the secretary's effort to prevent a labor-management impasse in steel failed, and on November 28, 1945, the NLRB conducted a Smith-Connelly strike vote which revealed that the majority of steelworkers $(607,282$ of 800,000$)$ supported a strike over wages. ${ }^{73}$

The USWA once again had placed itself on the strategic high ground. It had agreed to the secretary's call for the resumption of bargaining and conciliation, while the steel industry plainly refused. Moreover, it went through the appropriate steps under the Smith-Connelly Labor Disputes Act to conduct a strike authorization vote, thus more fully legitimizing a possible strike. Given the developing impasse brewing between labor and management in October 1945, Truman hoped that both parties might develop a cooperative working agreement to govern the

\footnotetext{
${ }^{72}$ Ibid, 29.

${ }^{73}$ IEB, December 10-12, 1945, Box 42, Folder 7, 4-7.
} 
labor-management relationship throughout the reconversion period. His Labor Management Conference, slated to begin early November 1945, would ultimately prove a disastrous failure that worked to highlight the reemergence of overt class conflict and became a turning point in the nation's path to the 1946 strike wave.

On October 30, 1945, President Truman, fearing the national economic ramifications of continued labor-management unrest, gave a speech to the nation that focused on the imperative need for labor and management to cooperate during reconversion. To achieve that goal Truman called a Labor-Management conference slated to begin on November $5 .{ }^{74}$ Truman stressed that voluntary cooperation was the basis of the conference. He hoped that both labor and management could peacefully and voluntarily agree upon dispute resolution procedures specifically for the postwar reconversion period. Ultimately for Truman, if labor and management failed to cooperate and strikes persisted during reconversion, the establishment of a prosperous and productive peacetime economy might be in peril.

Truman made it a point to address the conference as it opened. He told the attendees that the conference was not a government imposition declaring, "I want to make it clear that this is your conference — a management labor conference — and not a Government conference." 75 He stressed the need for all parties to agree on an "industrial relations" policy to more constructively facilitate the peacetime reconversion process. He acknowledged that the transition from war to peace thus far had been shaky as many strikes were already underway and the threat of more strikes loomed. For Truman, labor-management disputes had the inimical ability to threaten the

\footnotetext{
${ }^{74}$ Harry S. Truman: "Radio Address to the American People on Wages and Prices in the Reconversion Period.," October 30, 1945. Online by Gerhard Peters and John T. Woolley, The American Presidency Project. http://www.presidency.ucsb.edu/ws/?pid=12303.

${ }^{75}$ Harry S. Truman: "Address at the Opening Session of the Labor- Management Conference.," November 5, 1945. Online by Gerhard Peters and John T. Woolley, The American Presidency Project. http://www.presidency.ucsb.edu/ws/?pid=12300.
} 
nation's transition to a peacetime economy. He thus asserted, "The important thing is to remember that those problems - and their solution — cannot be allowed to stop us in our struggle to reconvert from war to peace. For until we successfully reconvert our productive capacity, we cannot hope to proceed toward our goal of full employment and an increased standard of living."76

To accomplish his goal, Truman suggested a possible labor-management policy for both sides to consider. First, the President advised that both parties enter into collective bargaining conferences "with an open mind."77 Second, he recommended that labor and management agree that if and when negotiations broke down the parties would use "impartial machinery for reaching decisions on the basis of proven facts and realties." ${ }^{\prime 78}$ Third, once a successful intervention was made, both sides would abide by the written agreement. Finally, Truman argued that jurisdictional disputes should not be an excuse to shut down production, and he also took a jab at industry, declaring that its track record for fair bargaining had in many instances been historically rocky. ${ }^{79}$ Truman closed his remarks to the conference reiterating that successful reconversion relied first and foremost on ramping up national peacetime production to ignite and sustain the nation's economic engine. Moreover, he cautioned that if conflict was not contained the country might slide into a recession or, even worse, another depression. "Our unparalleled opportunity may not long remain open," Truman declared, "We must have production—vast production. We must have it soon." 80

\footnotetext{
76 Ibid.

77 Ibid.

${ }^{78}$ Ibid.

${ }^{79}$ Ibid.

${ }^{80}$ Ibid.
} 
Truman's opening remarks might very well have been the high point of the conference for when he concluded, the conference devolved into a conflicted and frustrated gathering of deep seeded class division combined with an internecine squabble within the house of labor, as Philip Murray ran headlong into an AFL/Railroad Brotherhood/UMWA alliance bent on frustrating and undermining Murray's wage agenda. Consequently, Truman's desire to see labor and management voluntarily agree to terms to govern the reconversion period was doomed.

Before arriving at the conference, Philip Murray remained severely skeptical of the efficacy of the conference. Murray foresaw trouble from all parties involved, including government, industry, and especially from his one-time mentor, John L. Lewis. At the October 27, 1945 IEB, Murray told the board he was doubtful of what the government could accomplish for labor, inferring that in all likelihood the only remedy for the steelworkers was a strike: "I talked this morning before I left home to a number of people in the Government, and I did not indicate any desire to interest myself in any of the things that they had in mind. I explained that we had a lot of work to do getting our organization ready for what seemed to be the inevitable, and unless the Government was prepared to go forward with a forthright constructive policy, there might be no use of my even meeting with them." ${ }^{11}$

Murray believed that the upcoming LMC was as much about public propaganda as it was in trying to broker labor-management peace and continuous production. He confessed that "The Government is going to try to focus the attention of the people upon that meeting, because the Government is living in the hope that out of that meeting will come some plan designed to prevent, if possible, wide-spread industry disturbances during the period of reconversion." ${ }^{\prime 2}$ Furthermore, Murray announced that the industry representatives at the conference, particularly

\footnotetext{
${ }^{81}$ IEB, October 27, 1945, Box 42, Folder 6, 31.
}

${ }^{82}$ Ibid, 32-33. 
the NAM and the Chamber of Commerce, who "have been in substantial agreement with the representatives of non-union employers," would make it difficult for any type of positive and constructive outcome at the conference. Moreover, Murray noted that the CIO's voting power at the conference would be curbed considering that John L. Lewis would most likely side with the AFL and the Railroad Brotherhoods, giving that block more votes than the CIO. ${ }^{83}$ Lastly, Murray predicted that Lewis would probably try to steal the show declaring that Lewis, "in his dramatic fashion will throw his hair back, and speak for the people." ${ }^{84}$ Ultimately, Murray's reading of how the upcoming labor-management conference would go proved prescient.

Once the conference got underway a number of issues consumed it. One issue that management pushed was their desire to amend the Wagner Act, an idea that had obsessed industry from the act's inception in 1935. Efforts to promote the amending of the Wagner Act had evolved and gained momentum throughout the war and into the reconversion period. Indeed, prior to V-J Day, Congress had been debating the Burton-Hatch-Ball bill (a predecessor of the eventual Taft-Hartley bill of 1947), which, according to USWA counsel Lee Pressman, looked to erode "equality of bargaining power" and "legal protection" provided under the Wagner Act. ${ }^{85}$

On the issue of amending the Wagner Act, New York Times reporter Louis Stark observed that "each side is so tenacious of its viewpoint that the cleavage will probably run through the entire session." Noting further, "if the industry group had hoped to point up its program to prove to Congress that labor opposes any type of legislation involving changes in

\footnotetext{
${ }^{83}$ Ibid, 34-36; Louis Stark, “Lewis Wins Seat on Steering Group of Labor Meeting," New York Times, November 7, $1945,1,9$.

${ }^{84}$ IEB, October 27, 1945, Box 42, Folder 6, 34.

85 "Labor and Management Agree on Few Points," New York Times, November 25, 1945, 78; IEB, July 30-August 4, 1945, Box 42, Folder 4, 210-211.
} 
labor status, it has succeeded." 86 Another issue pushed by industry was its desire to have labor retain its "no-strike pledge" throughout the reconversion period. According to Stark labor was willing to accept a no-strike pledge only during periods of conciliation. ${ }^{87}$ The conference also discussed the possible establishment of government "fact-finding" boards to review the merits of labor-management disputes, something President Truman favored. Stark observed that labor was willing to allow such boards; however, industry refused because they were uneasy about the board's potential capacity to delve into their financial records. ${ }^{88}$ It seems the only issue that all parties could agree on was "the principle of collective bargaining," which the New York Times hailed as "significant" considering the inability of labor and management to agree on that principle after World War I. ${ }^{89}$ Stark's last observation is interesting given that postwar class conflict throughout the 1950s and 1960s would for a period of time, at least on the surface and in the light of day, pacify itself on the altar of collective bargaining in what historians would call the "Treaty of Detroit," and the postwar "labor management accord." However, as highlighted in Stark's observation of the LMC, a deeper and more sinister class war was emerging behind the façade of collective bargaining as industry was diligently working to erode the strength and power of the American labor movement. ${ }^{90}$

\footnotetext{
86 "Labor and Management Agree on Few Points," New York Times, November 25, 1945, 78.

${ }^{87}$ Ibid.

${ }^{88}$ Ibid.

89 “The Nation: Collective Bargaining Dramatis Personae Leaders Class NLRB's Job," New York Times, November $11,1945,62$.

${ }^{90}$ Postwar "consensus" historians viewed the rise of postwar collective bargaining, particularly the 1950 UAW/GM contract known as the "Treaty of Detroit" as a positive outcome marking an end to the labor-management warfare characteristic of the late nineteenth century and the first half of the twentieth century. For a more in-depth view of the socio-economic foundation of the postwar "liberal consensus" see Godfrey Hodgson, America in Our Time: From World War II to Nixon--What Happened and Why, (Princeton, Princeton University Press, 2005); For a detailed essay on postwar consensus history and the labor movement see David Brody, Workers in Industrial America: Essays on the Twentieth Century Struggle (New York: Oxford University Press, 1993) Chapters 5 and 6. For a critical anti-consensus perspective on the rise of postwar collective bargaining and the emergence of large bureaucratic unions such as the UAW and the USWA see "New Left" historian Nelson Lichtenstein, The Most Dangerous Man in Detroit: Walter Reuther and the Fate of American Labor (New York, NY: Basic Books, 1995); For a work that acknowledges the problems associated with top down bureaucratic unionism but at the same time
} 
At the LMC Philip Murray insisted that industry recognize the need to raise wages. Murray's resolution was not a call for the conference to set a particular percentage increase, but instead, sought an acknowledgment from industry that workers needed an increase in wages due to wartime constraints and fears that cutbacks in production and employment could lead to a recession. Murray's resolution as paraphrased by Louis Stark declared "that collective bargaining had broken down 'in many important situations,' that the parties call on labor and industry to engage in 'genuine' collective bargaining, and that the framework for such conferences was set forth by President Truman's declaration that wage rises were 'imperative.",91 It is important to note here that Murray's resolution mirrored exactly the Steelworker's experience with industry before the labor-management conference. The steel industry had met the union's effort to bargain over wages with stone cold intransigence. Thus, the Steelworkers believed the industry's refusal to bargain over wages did not amount to "genuine collective bargaining."

As one might assume, the majority of industry representatives at the conference did not support Murray's wage proposal. However, a more significant blow was that allied with industry against Murray's wage resolution were both the AFL's William Green and John. L. Lewis of the UMWA. Indeed, once Murray submitted his resolution on wages, Lewis looked to use the resolution as a club to beat Murray over the head, thus making the issue a sharp line of demarcation between the CIO agenda and that of Lewis and his AFL allies. During the debate over the wage issue Lewis called Murray's resolution, "innocuous, feeble and mamby-pamby.",92

\footnotetext{
argues that imperfect organizations such as the UAW never abandoned their goal of building a progressive postwar society see Kevin Boyle, The UAW and the Heyday of American Liberalism, 1945-1968 (Ithaca: Cornell University Press, 1995); and on the postwar business influence and the development of the anti-labor movement see FonesWolf, Selling Free Enterprise; Phillips-Fein, Invisible Hands.

${ }^{91}$ Louis Stark, "Lewis and Murray, Clash Over Wages at Labor Meeting," New York Times, November 9, 1945, 1,3 . ${ }^{92}$ Ibid.
} 
He argued further that Murray's resolution was akin to something resembling a cost of living increase. ${ }^{93}$ Indeed, Lewis viewed the Labor Management Conference as a tool to regain a stronger foothold as a national labor leader, which he himself had weakened in his support for Wendell Wilke against FDR in the 1940 presidential election and his subsequent fallout with Murray. ${ }^{94}$ Lewis also used his opposition to Murray's resolution as a platform from which to appeal to the business community. According to Louis Stark, Lewis got up before the conference and "made what industry members later agreed was one of the best speeches on free enterprise that they had ever heard." 95 Stark observed that, unlike Murray, Lewis was against any government restrictions governing the bargaining relationship. A regulated bargaining environment as seen by Lewis was not advantageous to labor. Instead, like capital, labor needed to be free to meet capital in an unrestrained bargaining environment, certainly not in the still restricted labor-management environment associated with reconversion. In Lewis's libertarian labor management dream, where he believed the power of capital equal to the power of labor, capital would be free to manage and labor would be free to use its power to secure its share of the surplus. Key among the supposed bounties acquired by labor would be those associated with management's freedom to employ labor-saving technology. Stark noted that Lewis's "view was that under the American economic system of free enterprise labor was entitled to share with investors and the public in the fruits of American technological geniuses as these were translated from the material sciences to increases in productive efficiency." 96 Stark summed up Lewis’s position noting, "The only limitations on collective bargaining he desired to see were free

\footnotetext{
${ }^{93}$ Ibid.

${ }^{94}$ Robert H. Zieger, The CIO, 1935-1955 (Chapel Hill: The University of North Carolina Press, 1997), 106-110.

${ }^{95}$ Louis Stark, “Lewis and Murray, Clash Over Wages at Labor Meeting,” New York Times, November 9, 1945, 1,3 . 96 Ibid.
} 
enterprise and free competition." 97 It is interesting to note that here we see the emergence of the ideological roots of Lewis's future effort to build and finance the UMWA's pension and social insurance fund. Ultimately, Lewis tied the financing of the fund to increased productivity and management's right to introduce job-killing technology, which over the postwar era led to the displacement of thousands of miners. ${ }^{98}$ Lewis, who during his free enterprise speech argued against continued OPA controls and failed to broach the topic of wartime profits, declared that "the miners could not afford to vote for a resolution offered by the CIO that bound labor to a cost of living formula, giving labor a chance to advance its wages only as the price of milk, children's shoes or straw hats advanced." 99 Upon stepping down from his soapbox, Murray, angered by what he had just heard, spoke up and "asserted hotly that 'the CIO is not afraid of anybody and I am not afraid of you.' 'Nuts,' Mr. Lewis said. 'Nuts to you,' replied Mr. Murray.' 100

After the LMC concluded, Murray made it a point to describe to the IEB his experience at the conference. He noted that from day one he faced both employer and labor groups hostile to his position on wages noting, "They consistently, fought our resolution every day. In the Executive Committee, they laughed and chided and kidded about CIO making an issue out of wages" at the conference. ${ }^{101}$ According to Murray, there were only a handful of business representatives in attendance who were sympathetic to his wage resolution; most opposed it, including the Chamber of Commerce. He argued that the anti-wage forces stooped to

\footnotetext{
${ }^{97}$ Ibid.

${ }^{98}$ See Richard P. Mulcahy, A Social Contract for the Coal Fields: The Rise and Fall of the United Mine Workers of America Welfare and Retirement Fund (Knoxville: University of Tennessee Press, 2001).

${ }^{99}$ Louis Stark, "Lewis and Murray, Clash Over Wages at Labor Meeting," New York Times, November 9, 1945, 1,3 .

${ }^{100}$ Ibid.

${ }^{101}$ IEB, December 10-12, 1945, Box 42, Folder 7, 15-16.
} 
"parliamentary subterfuges," stating further that, "this kind of skul-duggery was manipulated by Mr. Lewis and Mr. Green and Mr. Mosher and Mr. Johnston.”102

Murray went on to explain in depth his reading of Lewis and Green's behavior at the conference declaring that they both "made direct personal appeals to the managers represented at the meeting for their support." Adding that both men:

Sought to imply that my resolution sought the creation of a corporate state, and that therefore it should be opposed by all good, sound, constructive, free enterprise, and in support of that line of reasoning Mr. Lewis submitted an extemporaneous talk to the Executive Committee one day that lasted some fifty minutes, the substance of which was, 'I am the man, you ought to support me; I've got a white horse out here, you can provide the saddle and the reins and I will take it and I will help you. I love the system of free enterprise. I love higher profit, I love extortion of prices and I love high wages. I really adore the system of free enterprise, so, gentlemen, won't you support me? That was the substance of the Lewis address to the Executive Committee, and it was pointed particularly to the employer. ${ }^{103}$

Van Bittner also took an opportunity to deconstruct Lewis's free enterprise remarks, declaring before the IEB, "I am for free enterprise and I am for genuine collective bargaining, but not for free enterprise and free collective bargaining;" the latter, Bittner reminded the board, was the kind of economic freedom that governed the 1920s and early 1930s. Bittner thus stressed that back then, "enterprise was so free that industry and finance was bankrupt." Furthermore, "collective bargaining was so free that men and women and children of labor were starving to death in the United States."104

Next Murray described a rather peculiar event that took place in the latter stages of the conference. Abruptly changing their position, Lewis and Green at the close of the conference submitted their own resolution supporting wage increases but with less forceful language than Murray's resolution. This abrupt change shocked Murray, who stated that the Lewis/Green wage

\footnotetext{
${ }^{102}$ Ibid, 17.

${ }^{103}$ Ibid, 17-18.

${ }^{104}$ Ibid, 47-48.
} 
resolution was "the most hypocritical thing you ever did witness in all of your life." 105 Although Lewis and Green finally came out in favor of a wage increase, Murray refused to lend his support because of the weak language of the resolution and, it can be readily assumed, because of the unsavory behavior of both men at the conference. By the close of the conference, neither resolution had passed. Murray ended his remarks about the LMC offering stringent criticism of both Lewis and Green suggesting that if both men would have supported his resolution from the start of the conference "I don't think we would have been cursed with widespread strikes today throughout the United States."

After the conclusion of the LMC, Truman made an address to the nation. He argued that since labor and management could not come to a voluntary agreement on the dispute resolution procedures to govern the reconversion period, he was thus forced to call upon Congress to pass legislation based on his recommendations. Truman outlined his plan, which looked very similar to the Railway Labor Act of 1926 but with one crucial difference. Unlike the Railway Labor Act, Truman's labor-management policy went so far as to restrict a union's right to strike while a government fact-finding board investigated the issue. Moreover, the government could use punitive measures on those labor organizations that refused to abide by the act. Unfortunately for Truman, he could never mobilize enough political support to pass his plan in Congress, as both labor and industry were steadfast against the legislation. Labor argued that the policy was an attempt "to restrict the right of free Americans to strike."107 According to Murray, business lined up against the legislation because "they don't want anyone to investigate their books or their confidential records." ${ }^{\prime 108}$ Since Truman was unsuccessful in getting Congress to pass his

\footnotetext{
105 Ibid, 22.

106 Ibid, 23.

${ }^{107}$ IEB, December 10-12, 1945, Box 42, Folder 7, 111.

${ }^{108}$ Ibid, 111-113.
} 
recommendations, he subsequently used his power as chief executive to intervene in the ongoing labor-management disputes to include the GM/UAW dispute and the US Steel/USWA dispute. However, the fact-finding boards under executive authority alone lacked the punitive measures associated with his proposed congressional legislation.

In the aftermath of the President's address to the nation, Murray went on the radio to criticize the president's proposal. Rather than restrictive Congressional legislation, Murray simply wanted the President to support and release the facts of the steel dispute already compiled in the Nathan report. According to Murray, the Nathan report clearly established that labor, in general, was in severe need of a wage increase and that industry, flush with war profits, had the means of raising wages without undermining the finical soundness of the enterprise. With the Nathan report already completed, Murray thus argued that the president's idea of fact-finding boards was redundant and unnecessary. Indeed, the resolution passed by the IEB after the president's national address condemned industry's unwillingness to bargaining, the president's fact-finding boards, and Truman's legislative proposal, calling the entirety of the situation "a false trial of fruitless delays which can only serve to undermine labor." 109

Days after Murray's radio address, some district directors offered their support of Murray's critical words as well as his actions at the LMC. Director Tomayko, for example, declared before the IEB that he wanted everyone "to know that the position our president has taken in the Labor Management Conference did more good in my district than anything else I know of." 110 Furthermore, Tomayko described how over 50 coal miners in his district had visited him to tell him how they were disgusted with John L. Lewis. ${ }^{111}$ Finally, Tomayko

\footnotetext{
${ }^{109}$ Ibid, 113.

${ }^{110}$ Ibid, 81.

${ }^{111}$ Ibid, 81-82.
} 
declared, “I don't know how many Steelworkers met me on the street and in the office and made fine, nice comments on that speech."112 Thus it seems Murray's stance on wages and his combative stance against Truman resonated with many rank-and-file members of the union.

Murray, via his work with the War Mobilization and Reconversion Office, was intimately aware of the fact that the government already had the statistical facts necessary to determine whether or not labor was justified in its claim for a wage increase. According to Murray, the Nathan report concluded "that on average American industry could absorb this 24 percent wage increase without increasing prices." 113 The report also recognized that some companies on a case by case basis might not be able to absorb such an increase and might truly need price relief. However, basic steel was shown in the report to be able to absorb a 24 percent increase in wages without raising prices. ${ }^{114}$ Murray proposed to the War Mobilization and Reconversion office that the report be released to the public, but Director Snyder "expressed opposition to releasing it." 115 The War Mobilization and Reconversion board then met with President Truman to discuss the possibility of releasing the report. Murray recounted that the President did not make a determination as to whether the report should be released. All that Murray knew as of midDecember 1945 was that the President might address the nation about the report. ${ }^{116}$ However, rather than releasing the document, Truman called instead for punitive Congressional legislation and fact-finding boards, which were unpalatable for Murray and the USWA.

Murray counseled the IEB on the president's actions and pointed fingers at such people as Director Snyder of the War Mobilization and Reconversion board, who Murray referred to as

\footnotetext{
112 Ibid, 82.

${ }^{113}$ Ibid, 115-116.

114 Ibid, 116.

115 Ibid, 117.

${ }^{116}$ Ibid, 119.
} 
"an enemy of organized labor." Murray did not specifically blame Truman for the problem, but he was severely critical of those who had the President's ear noting, "the President's difficulties are the Snyders that are around him." 117 Van Bittner also took a moment to give his thoughts on the situation. He more directly criticized the President arguing that his actions over the past months and weeks were precisely why organized labor should not prioritize government intervention. Bittner denounced the idea of punitive legislation and declared that such a proposal highlighted the President's true colors in relation to organized labor. Bittner attacked Truman as a week and feeble president declaring, "I don't know that it is necessary to say anything about him, only to say that I think that Calvin Coolidge was a strong-minded citizen compared with the present President of the United States." ${ }^{118}$

By late 1945, steel industry leaders were well aware that steelworkers across the country were demanding a significant wage increase to offset the wage losses incurred due to wartime wage controls. Thus, the steel industry's first priority in the postwar reconversion period was to prevent a wage increase; however, if that was not possible, the industry wanted government authorization to increase the price of steel to offset the cost of wage increases. Philip Murray was keenly aware of the industry's position. Murray and the steelworkers were against the idea of raising prices but ultimately believed that the price issue was out of their hands. The union maintained that the steel industry was flush with war profits and could easily absorb a wage increase without raising the price of steel, but it also recognized that some smaller steel companies might need price relief to absorb the cost of increased wages. ${ }^{119}$ However, Murray, unlike Walter Reuther of the UAW, believed that the price issue was a battle between industry

\footnotetext{
${ }^{117}$ Ibid, 120.

${ }^{118}$ Ibid, 46.

${ }^{119}$ Ibid, 14 .
} 
and the government and that the steelworkers had limited power over impacting the outcome of that battle. ${ }^{120}$

Murray was not in favor of the UAW's bargaining strategy. He told the IEB that the GM/UAW wage conflict was "based substantially upon the question of ability to pay."121 He noted further that "We [the USWA] don't see that a collective bargaining contract could be based upon ability to pay, because there are many poverty stricken employers that have either to get price increases or go out of business." ${ }^{22}$ Instead, Murray argued the issue for the USWA was that "we want a wage increase" across the entire industry. ${ }^{123}$ Although the union maintained its position that large steel companies such as US Steel did not need price relief to absorb the cost of a wage increase, it did not focus on it. Thus, Murray told the IEB that "we are not making a special issue out of that, because we know that the final determination over what the price structure might be in the steel industry will have to be disposed of by both the Office of Price Administration, the Director of War Mobilization and Reconversion, and perhaps the President of the United States."124

By late 1945, the steel industry was actively lobbying the federal government to allow for a price increase. The fight to win a price increase was a long and drawn out process that witnessed internal governmental squabbling over the issue and was a major barrier to the industry's willingness to enter into legitimate negotiations. As noted earlier, the steel industry had not been willing to enter into legitimate bargaining with the union. Furthermore, John

\footnotetext{
${ }^{120}$ Ibid, 14-15; Walter Reuther's postwar bargaining strategy went beyond the demand for increased wages, and instead, demanded that GM allow the union to review its financial accounts to prove or disprove GM's ability to afford wage increases see Nelson Lichtenstein, Labor's War at Home: The CIO in World War II (Philadelphia: Temple University Press, 2003), 225-226.

${ }^{121}$ IEB, December 10-12, 1945, Box 42, Folder 7, 30.

122 Ibid, 30-31.

${ }^{123}$ Ibid.

${ }^{124}$ Ibid, 32.
} 
Stevens of US Steel made it clear to Murray that the company would not discuss the issue of wages, "until the Government of the United States gives us a price increase." ${ }^{125}$ Stevens informed Murray that the industry believed that it would take until February 1946 before the government could rule on the issue of a price increase because the OPA had "to look at the last quarter's earnings in industry." ${ }^{26}$ However, Stevens was optimistic that the company would win its case for a price increase in February and requested that the union wait until then before considering a strike. Murray refused his request telling Stevens that he "didn't think our people would want to do that, that we had a mandate from our people and a grant of authority" to strike. ${ }^{127}$ Consequently, the USWA IEB and Wage Policy Committee set an initial strike date for January 14, 1946.

As the steel industry looked to be gaining ground in their effort to secure a price increase and as the January $14^{\text {th }}$ strike date loomed on the horizon, negotiations between the USWA and US Steel resumed in early January 1946. On January 10, US Steel requested that Murray and a few key union officers come to New York City to discuss the wage issue. Murray obliged the request. At the meeting, Ben Fairless offered Murray a 12.5 cent an hour wage increase. Murray viewed this request as a slap in the face noting that "the offer was unthinkable, wholly unacceptable, and was not even a negotiable offer."128 The next day, Murray demanded a 20 cent an hour wage increase, which US Steel refused. Formal negotiations disintegrated. Rather than ending negotiations altogether, Ben Fairless requested that he and Murray try to work out a deal. At that meeting, Fairless offered a wage increase of 15 cents an hour, which Murray rejected. ${ }^{129}$

\footnotetext{
125 Ibid, 33.

126 Ibid.

127 Ibid, 34.

${ }^{128}$ IEB, January 23, 1946, Box 42, Folder 8, 16.

${ }^{129}$ Ibid, 18.
} 
Murray then countered with a demand of 19.5 cents an hour, a number that had significance. Just before the January 10-11 steel negotiations, the government fact-finding board in the GM/UAW wage dispute found in favor of a wage increase for auto workers of $19 \frac{1}{2}$ cents per hour. Murray thus told Fairless that the union would reduce our 20 cents demand to $191 \frac{1}{2}$ cents, "which is the General Motors fact-finding report." Murray recalled that Fairless believed his proposal to be "eminently fair." However, before Fairless would accept, he asked for a week to seek approval from US Steel's board of directors. ${ }^{130}$ Murray refused the extension and negotiations ended once again in an impasse.

Upon hearing that steel negotiations failed to reach an agreement, President Truman requested that both parties meet with him on January 12 to discuss the issue of wages. Both parties accepted and traveled to Washington D.C. to meet with Truman. Recounting the meeting, Murray noted that Truman was "visibly agitated, fearful about the disastrous consequences that might trail in the wake of a great steel strike." ${ }^{\prime 131}$ Although Truman desperately desired an agreement, both parties remained fixed to their earlier demands. Murray told the president that the steelworkers demanded $19 \frac{1}{2}$ cents an hour and Fairless informed the president that the steel industry was willing to give 15 cents an hour. Truman, meeting with both parties at the same time, could not get either to budge on the issue. He then changed his strategy and subsequently tried to work out a deal on an individual basis first with Fairless and then with Murray. According to Murray, Truman told Fairless that he believed the union's demand of $191 \frac{1}{2}$ cents an hour was "fair." Still, Fairless would not budge and requested that the president give him a week to discuss the matter of $191 / 2$ cents with his board of directors. ${ }^{132}$ Murray described

\footnotetext{
${ }^{130}$ Ibid, 19-20.

${ }^{131}$ Ibid, 22.

${ }^{132}$ Ibid, $22-24$.
} 
his meeting with Truman: "I was brought in and the President, of course, was still visibly agitated, very much upset. It appears that he was upset about the things I had said about him over the radio, and he was upset about the strike. He expressed anger. He pounded the desk and said that this tragic situation was not going to occur if he could prevent it. Then he exclaimed loudly that I could not do this to him."133 After venting, Truman asked Murray to postpone the strike and give Fairless a week to discuss the matter with his board. Murray responded to Truman's request stating "as a citizen and as one who respects the office of the President, I can see no reason why I should refuse to accede to a reasonable request of this description." 134 The president was delighted with the response and made arrangements for the next meeting.

When negotiations resumed on January 16, Ben Fairless informed the President that his board refused to accept the USWA's 19 1/2 cent an hour demand. ${ }^{135}$ The industry's unwillingness to compromise angered Truman and he declared to both parties that he would make a formal recommendation on wages the following day. Murray recalled that on January 17, "The entire industry was over in the city of Washington. Its leg men were busy, running hither and yon trying to exercise their influence and their power to get the right sort of a commitment out of the President of the United States. We knew of that but we did not interfere."136

At 4 pm on January 17, Truman issued his recommendation. He suggested that the industry should accept a wage increase of 18 1/2 cents an hour retroactive to January 1, 1946. After issuing his recommendation, Truman gave the parties 4 hours to think about the proposal and provide him an answer by $8 \mathrm{pm}$. Upon hearing the President's recommendation, Fairless informed the President that the offer would not be palatable for those he represented in the steel

\footnotetext{
133 Ibid, 24.

134 Ibid, 25.

135 Ibid, 26-28.

${ }^{136}$ Ibid, 29-30.
} 
industry and asked the president to extend the response time to noon on January 18. Truman obliged the request and subsequently rescheduled the deadline. Although Truman may have hoped for an agreement to avoid a steel strike, a deal failed to materialize. ${ }^{137}$ At noon on January 18, both parties gave Truman their response. Fairless informed the President that his board would not accept the proposal. Murray, on the other hand, accepted the President's offer and yet again attempted to guide the union to the strategic high ground. He advised the board on why he chose to take the president's offer rather than continue to demand $191 / 2$ cents an hour. For Murray, the fact that the president specifically intervened in this wage dispute lent increased credibility to the union's effort to secure a wage increase and the chief executive supported a wage increase that was very close to the union's initial demand. "It is not a recommendation from the fact-finding board," Murray declared to the IEB, "it is not an ordinary recommendation from a governmental conciliator; it is a presidential decision which we have accepted and which the industry has refused. That is of tremendous significance." 138 Thus, Murray reiterated before the board that "the position of the organization is that we are again supporting the Government, supporting the people, and supporting the President of the United States. So that no organization at any time within my memory occupied a more strategic position, a better position to win and curry public favor in a strike than does the United Steelworkers of America."139

As the President's attempt to conciliate a wage deal between the USWA and US Steel failed, the USWA was ultimately forced to call a strike on January 21, 1946. However, before the official start of the strike Philp Murray met with Henry Kaiser and was able to win a contract at Kaiser's Fontana, California mill allowing for an $18 \frac{1}{2}$ cent an hour increase retroactive to

\footnotetext{
${ }^{137}$ Ibid, 31.

138 Ibid, 33.

139 Ibid 34.
} 
January 1, 1946. The ease of these negotiations stemmed from the fondness each man had for the other. Moreover, upon completion of the agreement Henry Kaiser made public statements that argued that the rest of the large steel companies were wrong in fighting the union's demand, and that in the grand scheme of things, the difference between the company's demand of 15 cents an hour and the union's demand of $18 \frac{1}{2}$ cents an hour was "inconsequential." ${ }^{440}$ Kaiser's comments suggested that the impasse between the USWA and the steel industry was more than just an issue of dollars and cents, but rather an issue of ideology and power.

The strategic high ground was significant to Murray as the union would continue to face the mobilization of the steel industry's economic power, which was trying to shape the public's perception of the union as untrustworthy violators of the current 1945 contract. Murray addressed that issue at the first IEB meeting held two days after the start of the strike. He noted that the media had been incorrectly charging that the union was in violation of the contract. Murray believed the media's reporting on the issue was nefarious and that these false charges "indicate the extent to which these powerful influences, namely the steel industry, will go to defeat the legitimate aims of a trade union possessed of conscience and integrity."141

Indeed, the USWA was not in violation of the contract. In fact, the organization took significant measures to ensure that they adhered to the contract and the law that governed their current contract. That contract, according to NWLB guidance, allowed for its reopening over the issue of wages if and when the National Wartime Wage policy changed, which occurred after VJ day. Subsequently, the union began the process of bringing a much-needed wage increase to their members. However, the public has never been well versed in the intricacies of contract law, and thus the issue of whether one has adhered to, or violated, a contract can be easily manipulated by

\footnotetext{
140 Ibid, 60.

141 Ibid, 35.
} 
a campaign of misinformation. Murray understood this. For Murray, a belligerent and aggressive campaign of economic power pursued by the union in the postwar era would have more easily allowed the steel industry to paint the union in a negative light, allowing them to sell their anti-union message to the public. Murray's strategy was not just designed to win a single event like the 1946 steel strike. The union wielded enough economic power to win that strike and losing public favor in 1946 most likely would not have meant the loss of the strike. Instead, Murray understood that staying in the favorable graces of the public coming out of the war and into the postwar era would help the USWA and the CIO weather a growing corporate campaign to undermine the union movement. ${ }^{142}$ However, despite these strategic maneuvers, Murray overestimated how the public would react to a strike, especially a strike in which the USWA took all of the necessary precautions to retain public favor.

For Murray, the industry's intransigence on the wage issue was just the tip of an industrial anti-union campaign against labor. He counseled the IEB declaring, "I have charged in the papers that Big Business has engaged itself in a conspiracy to destroy labor unions."143 Likewise, the USWA's 1946 strike resolution declared that "American industry drunk with exorbitant profits exacted as its price for war production, seeks to grasp complete control of Government and thereby determine the destiny of our nation." In the union's mind, the CIO and the USWA were "the obstacle to this [corporate] dream of conquest." 144 Thus, the resolution asserted that, "the issue is now one between the American people, the United States Government and the sinister industrial and financial despots who yearn for unlimited power and absolute

\footnotetext{
${ }^{142}$ See for instance, Elizabeth A Fones-Wolf, Selling Free Enterprise: The Business Assault on Labor and Liberalism, 1945-60 (Urbana: University of Illinois Press, 1994).

143 Ibid, 43.

${ }^{144}$ Ibid, 54.
} 
control over the affairs of our country." ${ }^{145}$ Lastly, the resolution declared that business interests were actively conspiring to erase or amend the Wagner Act and that the union had it on good authority that in January 1946, leaders of large corporations met to discuss plans to regain capital hegemony over labor, although the source record does not provide the details of such a plan. ${ }^{146}$

Formal negotiations between the union and U.S Steel were nonexistent from January 21 to February 4, 1946. During that period, the USWA focused on flexing its collective muscle by withholding its labor in a show of unified solidarity, while industry officials ran around Washington D.C. actively pressuring policy makers to open the faucet on steel prices. Stymied through the fall of 1945 by Chester Bowles, head of the OPA, who refused to budge on the price issue, the steel industry began lobbying John Snyder, Director of War Mobilization to grant a price increase. Still, by February 5 and 6, when the USWA and US Steel again entered into talks, the issue of price increases had yet to be resolved although it looked as if industry would ultimately win an increase. The question of when the price increase would be announced, preor-post strike settlement, became a major issue. ${ }^{147}$

As of February 1946, the USWA continued to maintain its distance in the ongoing price debate, going only as far as denouncing the need for large steel producers to raise their prices. Lee Pressman at the February IEB paraphrased Murray's stance on prices before the board noting, "we are not becoming involved in the price issue; that is something for the Government to handle, but we are requesting this, that it should be made perfectly clear to the steel industry that there would be no announcement of any increase in steel prices until the steel industry

\footnotetext{
145 Ibid, 55.

146 Ibid.

${ }^{147}$ IEB, February 21, 1946, Box 42, Folder 9, 7-8.
} 
signed an agreement with the United Steelworkers of America, consistent with the President's decision that there be a wage increase of $181 / 2$ cents per hour, retroactive to January $1,1946 .{ }^{\prime 148}$

As the strike progressed, John Stephens of US Steel reached out to Murray and requested a meeting on February 5 to discuss the strike. The two sides met on the evening of the $5^{\text {th }}$ and throughout the day on the $6^{\text {th }}$, during which US Steel delivered its demands. First, the company sought the elimination of the union's demand for retroactive wages to January 1, 1946. Next, the company requested the union agree to a non-discrimination clause for all employees that were loyal to the company during the strike. The company also requested the union agree to "a mutual objective for maximum production" and that the current contract, minus the wage issue, be extended from the original end date of October 16 to a new end date of May 1947. Lastly, the company requested that the union be open to future negotiations over "the inequalities provision" of the current contact and that the union accept a no-strike pledge for the duration of the contract. ${ }^{149}$ USWA leaders respectfully heard the industry's proposition and appeared closer than ever to an agreement. However, the parties could not close the deal as the price issue remained unresolved. Consequently, negotiations ended in an impasse.

Bargaining resumed on February 12, and this time both parties seemed poised to make a deal. Murray countered the company's request to extend the contract until May 1947, suggesting the new contract should end in February 1947. The issue of contract length concerned Murray greatly for he feared that if government price controls and oversight were reduced, particularly on things such as food and clothing, then the union would have immobilized itself from counteracting an inflationary trend via bargaining. According to Lee Pressman, the government had indicated to union leaders that it was serious in its efforts to extend the Price Control Act in

\footnotetext{
148 Ibid, 8-9.

149 Ibid, 6.
} 
order to regulate and control prices. The steelworkers were more concerned over the price of "basic items for the average worker" than the cost of industrial items such as steel. ${ }^{150}$ The union's view on inflation is an important point to consider and helps to explain the union's handsoff approach to the price battle in steel. Murray and other union leaders believed that the large steel companies had enough money to allow for a wage increase without a price increase; however, it believed that the issue was beyond their influence and hence the purview of government and business. Furthermore, they believed that inflation, caused by an increase in steel prices would be minimal and that the most important area of price control and regulation came in the realm of everyday consumer items such as food and clothing, which if allowed to inflate, could easily eviscerate any wage gains made by the union.

Although Murray was apprehensive about agreeing to a long contract period, the act of extending the contract did have one significant upside: for the first time the steel industry would voluntarily accept the dues check-off and maintenance of membership, which were already a part of the current contract forged during the wartime bargain between labor, management, and government. If the contact was allowed to expire on the original date of October 16, 1946, Murray believed the companies would fight vehemently against both the dues check-off and maintenance of membership. Extending the contract thus more fully legitimatized the dues check-off and maintenance of membership in the postwar era. According to Pressman, "In extending the contract from October 1946 to February 1947, for the first time in American basic industry, have large corporations voluntarily accept[ed] the maintenance of membership and check off without any government order."151

\footnotetext{
150 Ibid, 11-12.

151 Ibid, 13-14.
} 
By February 14, the two parties were close to a deal. The main issue of concern for the company was retroactive pay, while the main point of concern for the union was getting industry assurances that collective bargaining would take place at the subsidiary level and with smaller steel concerns after the parties settled the strike in basic steel. ${ }^{152}$ Murray was willing to compromise on the issue of retroactive pay and offered a half cut in retroactive wages from January 1,1946 , to February 14,1946 . This meant that rather than paying steelworkers the full $181 / 2$ cents an hour from January 1 to February 14 the company would only pay $91 / 4$ cents over that period. ${ }^{153}$

By the close of business on the $14^{\text {th }}$ it looked as if a deal was forthcoming; however, the Truman administration haphazardly announced the issuance of executive order 9697 (Providing for the Continued Stabilization of the National Economy During the Transition from War to Peace), which acted to disrupt the bargaining process. ${ }^{154}$ The order established a new procedural framework for both labor and management when seeking a wage or price increase in the reconversion period. Both parties did not at that time have clarity on how the order would impact the proposed deal, which brought negotiations to an abrupt halt. ${ }^{155}$

On February 15, amid the turmoil caused by Truman's executive order, Truman's Chief of Staff John R. Steelman and Secretary of Labor Lewis B. Schwellenbach offered some clarity on the price issue to both parties. According to Pressman, Schwellenbach told Roger Blough and John Stephens of US Steel that, "of course you gentlemen recognize that you do not get an announcement of your steel prices until you settle with the Steelworkers' Union.” Noting further,

\footnotetext{
152 Ibid, 22.

153 Ibid.

${ }^{154}$ Harry S. Truman: "Executive Order 9697-Providing for the Continued Stabilization of the National Economy During the Transition from War to Peace," February 14, 1946. Online by Gerhard Peters and John T. Woolley, The American Presidency Project. http://www.presidency.ucsb.edu/ws/?pid=77993.

155 IEB, February 21, 1946, Box 42, Folder 9, 22-23.
} 
"This was the first time that a member of the Cabinet had told the steel industry that the President of the United States did not intend to let that price order go until there was a settlement of the wage issue."156 This was welcome news for Murray, who had been lobbying government officials from the start of the strike to ensure such an intervention. ${ }^{157}$ Shortly after the Steelman and Schwellenbach announcement, the union and company agreed to a deal, which incorporated the industry demand to reduce the retroactive pay. Both sides agreed to retroactive pay of $91 / 4$ cents an hour from January 1 to February 15. Moreover, the industry gave assurances that the non-steel producing subsidiaries would engage in bona fide bargaining with the USWA. Lastly, the steelworkers won their $181 / 2$ cent an hour wage increase, combined with an extension of the March 1945 contract, which included maintenance of membership and dues check-off, to February $1947 .{ }^{158}$

Although the union and the company came to a tentative agreement, the union refused to sign the contract until it had greater clarity on the impact of executive order 9697. According to Pressman, the order was an attempt to "return to the days of the National War Labor Board," meaning that free collective bargaining would again be mediated by a third party. ${ }^{159}$ It required all business to seek government approval of price increases after they had granted a wage increase and it also made the National Wage Stabilization Board (NWSB) [the postwar remnant of the NWLB] the authority in regulating wage increases. Moreover, for labor to get approval of a wage increase, the increase had "to be consistent with a pattern for the particular industry in which that particular employee is involved, and that pattern...must be established February 14,

\footnotetext{
156 Ibid, 26.

157 Ibid, 9, 19.

158 Ibid, 26-27.

159 Ibid, 28.
} 
because the Board can't create new patterns." ${ }^{\prime 60}$ The fact that the new executive order began on the $14^{\text {th }}$, one day before the finalization of the 1946 contract, meant that the new contract between US Steel and the USWA might be invalid. However, Pressman assured the IEB that the union was exempt; the executive order had a loophole excluding NWSB approval of a wage increase if the parties involve had "a governmental award for a wage increase." The steelworkers had such an award, provided by the President of the United States back in early January 1946. However, Truman's finding of $181 / 2$ cents in January only benefitted basic steel and not steel fabrication and iron ore. ${ }^{161}$ Murray disliked the fact that the union would be subject to the executive order during its ongoing negotiations with steel fabricators and iron ore producers. Thus, before agreeing to the 1946 contract Murray used the union's economic power to push OPA head Chester Bowles to write an official letter exempting the Steelworkers from being subject to executive order 9697 for the union's upcoming bargaining in fabrication and ore. Although the Steelworkers would be exempt from the order, employers were still required to seek price relief from the OPA. With the Bowles exemption in hand, Murray agreed to sign the contract ending the 1946 steel strike. ${ }^{162}$

Although the union was victorious, key union leaders remained concerned about executive order 9697 and the continuance of government intervention in the postwar labormanagement relationship. Pressman was chief amongst the skeptics. He told the IEB that he was, "hopeful that we may be able to work out some procedure that will knock them completely out of business, because I am fearful that if the Wage Stabilization Board remains in business, to give these approvals, we will be at that business for the next six months or a year before an

\footnotetext{
${ }^{160}$ Ibid, 29.

${ }^{161}$ Ibid, 30-32.

${ }^{162}$ Ibid, 32-34.
} 
employer can get approval of that wage increase for the purpose of going to the OPA."163 Pressman further made disparaging remarks about the efficacy of the NWSB and its predecessor the NWLB, noting that (1) he did not believe the board would be able to handle the volume of cases; and (2) that after talking with some public members of the board, Pressman believed many of those public members were chomping at the bit to reassert governmental control over labor and industry. Pressman thus declared, "I can already see the glint in their eye indicating that they think they have us in their grasp again." 164 He added, "When we got out of their tolls August $18^{\text {th }}$ they were a bunch of frustrated individuals and they could no longer say, we know what is best for labor. But in the last few days I can see the glint in their eye again."165

Van Bittner also spoke up on the topic of government intervention. He reminded the board that he resigned from the NWLB on December 31, 1945. He added that after his resignation the union "told the President of the United States that we wanted no more boards of that type to settle disputes between labor and industry in America." ${ }^{166}$ Murray also weighed in on the issue, and he specifically counseled directors to avoid taking wage issues in fabrication and ore to the NWSB. He told the board that the NWSB was woefully understaffed and given the fact that the better-staffed NWLB had problems in delivering timely rulings, the NWSB would be much worse. Murray stated in regard to submitting cases to NWSB that the union, "ought to decide now that it is done with that sort of messy business, it is through with it, and that it will seek through the process of voluntary collective bargaining and a strike, if necessary, to secure redress for any wage wrongs that might be perpetrated against our people."167

\footnotetext{
${ }^{163}$ Ibid, 35

${ }^{164}$ Ibid, 39.

${ }^{165}$ Ibid, 39.

${ }^{166}$ Ibid, 63.

${ }^{167}$ Ibid, 50 .
} 
Murray concluded by speaking to the IEB about the meaning of the 1946 victory. He told the board that he saw a promising future for the union based on organizational strength. For Murray, the 1946 victory in basic steel proved to the nation that the USWA was a force to be reckoned with. He noted that since the union defeated basic steel, he felt confident that the union would soon win victories in fabrication and ore. Moreover, Murray announced that the union could not rest or become complacent declaring that "an organization with 750,000 men and women cannot afford, under any circumstances, to be either weak or vacillating. We demonstrated our fitness to rise to the occasion, we have won a great victory, a great moral victory."168 Ultimately, the union was able to mobilize its economic power to win short-term economic security in the form of a significant wage increase. Added to that the union was able to secure itself as a legitimate institution by getting management to voluntarily accept the dues check-off and maintenance of membership. Murray stressed this point before the board declaring, "four or five weeks ago that might have been an unthinkable thing for the industry to do, but after a four week strike the industry decided, by and through the process of voluntary collective bargaining, to recognize the universal system of union security and maintenance of membership."169 Lastly, Murray praised the union for conducting a peaceful strike. He argued that "riotous" behavior instigated on the part of the union is generally a poor strategy. He stressed to the board that "It is not the hypocritical gestures of riotous demonstrators that win victories, it is the determined, cold, calculating determination of human beings to sit down, to refuse to produce until victory attends their efforts." In Murray's estimation, the union did exactly that and won a momentous victory. ${ }^{170}$

\footnotetext{
168 Ibid, 52.

169 Ibid, 54-55.

${ }^{170}$ Ibid, 58-59.
} 


\section{Conclusion}

The 1946 steel strike was indeed a great victory for steelworkers and the labor movement in general. Philip Murray, backed by rank-and-file support for wage increases and a strike, drew upon past experiences to create a winning reconversion era strategy. Murray was a deliberate, thoughtful, and strategic planner who believed more in the primacy of organizational strength and economic power, i.e., labor's "original obligation," than in a steadfast reliance on federal intervention. He viewed government as a useful tool that could help the cause of labor; however, Murray also recognized that government could be slow, inefficient, and subject to the evershifting winds of political power. His outlook for the reconversion era was also shaped by his experiences with the labor movement after World War I. As World War II came to a close, Murry was determined to bring forth a better outcome for the USWA and the CIO by taking heed of the lessons of the past, in particular, emphasizing the use of labor's economic power combined with the promotion of postwar economic regulation designed to promote a full employment economy.

Murray also understood that a new type of class conflict was emerging in the postwar era. This was a class conflict that sprouted roots in the mid-1930s and had been gaining strength throughout the war. It was a class conflict dissimilar from the labor-management conflicts of the latter half of the nineteenth century and the first half of the twentieth century. Gone, at least for the time being, were bloody physical confrontations such as Homestead or the 1937 Little Steel Strike. In their place came something different; a response by capital that understood it was now living in a new political, cultural, and economic era, one forged by the rise of New Deal liberalism and the subsequent rise of the CIO and industrial labor unions such as USWA. Coming out of the war, capital had lost its economic and political hegemony to the "fragile 
juggernaut" of the CIO and to a large extent the AFL. ${ }^{171}$ Given this new context, capital had to come to terms with this new postwar reality and at the same time formulate new strategies to regain its political and economic dominance in an effort to undo the emerging New Deal liberal order. Indeed, in large part class conflict in the postwar era became a colossal struggle of interest groups competing for economic and political influence within a liberal democratic capitalist society. ${ }^{172}$

Murray's leadership in the immediate postwar era highlighted the fact that he was intimately aware of the new realities of class conflict in the postwar era and had adapted the union's organizational strategy to meet the new challenge. Murray understood that labor would be fighting less at the mill gate and more at the bargaining table, in the halls of Congress, and for the loyalty and support of the American public. His was a strategy built upon the idea that large organizations such as the USWA, and to a greater extent the CIO, wielded considerable economic and political power, and by growing and sustaining that power, the labor movement could bring forth and maintain prosperity and security for all Americans. However, before American laborers could fully realize the "American Dream" in what came to be called America's "affluent era," Murray and the USWA leadership, reacting to rank-and-file demands and a changing political environment, would next turn their attention to the issue of long-term welfare security.

\footnotetext{
${ }^{171}$ Robert H. Zieger, The CIO, 1935-1955 (Chapel Hill: The University of North Carolina Press, 1997), 1.
}

${ }^{172}$ See for instance C. Wright Mills, The Power Elite (New York: Oxford University Press, 1956). 


\section{Chapter 4: The USWA's Path to Private Security: The Postwar Retiree Crisis, Politics, and Postwar Communism}

\section{Intro: The Postwar Retiree Crises}

In April 1946, just months after the conclusion of the 1946 steel strike, Inland Steel in Chicago, began terminating workers who reached the age of 65 . Inland's action surprised many unsuspecting older workers who had no immediate plans to retire, given the weakness of both the company's pension plan and the nation's Social Security system. To USWA leaders and rank and file members alike, Inland's action, and the similar actions of companies such as US Steel seemed arbitrary, extreme, and most importantly, in violation of the contract and the rights of union members. When many of the discharged workers at Inland filed grievances against the action, the company refused to recognize those grievances arguing that pension and age policy were the sole purview of management and not subject to collective bargaining. The international union vehemently disagreed. The union claimed that the company had violated the "seniority" and "discharge" provisions of the 1946 contract, and subsequently filed an unfair labor practices suit with the NLRB. ${ }^{1}$ For the next three years, the Inland Steel case combined with the union's urgent need to help older workers, the disadvantageous national political environment and issues pertaining to postwar-anti-communism influenced the USWA's decision to bargain for private forms of security in 1949. Although the postwar labor-management accord ensured capital's right to manage, the issues of wages, pensions, social insurance, and local working conditions highlight the boundaries of contestation over postwar era managerial hegemony.

The forced retirement of older workers placed those workers in a very precarious situation. Indeed, forced retirements, combined with insufficient company pensions and a weak

\footnotetext{
1 “USA Fights Inland Action Firing 65-Year Old Men” Steelabor, July 1946, 4; Lee Pressman "Legislation.... the law and your Union” Steelabor, October 1946, 8.
} 
Social Security system caused many hardships for older steelworkers who in some instances had toiled in steel mills since their early teens. Murray Latimer, a social insurance expert, hired by the union in September 1947, spoke to the 1948 USWA convention about the economic condition of retired steelworkers. Latimer referenced a recently published Social Security Administration study that had established a rather modest subsistence level budget for a retired couple. For instance, the budget allowed for the purchase of one jacket every 20 years, and it estimated a retired couple's yearly budget to be $\$ 1,638$ ( $\$ 135$ a month). However, according to Latimer, neither public nor private means of old age security, as they existed in 1948, could provide retirees with an income at that level. ${ }^{2}$

Ever since the 1939 Social Security Amendments, which tied the system to the family unit rather than the individual worker, Congress had let the program lay fallow. ${ }^{3}$ Moreover, up until the 1950 amendments, the Social Security Old Age pension system was overshadowed by state-level welfare pensions, especially in the South where one out of four Louisianans age 65 or older received a state-based welfare pension. ${ }^{4}$ By 1948 both the CIO and the AFL realized the inherent weakness of the Social Security Old-Age pension system. For instance, in 1949 James A. Brownlee of the AFL argued that private means of security were needed, "Because the social security law has not been amended [and] because its provisions are so antiquated and unjust." Moreover, at the 1948 convention, the USWA described the Social Security system as "creaking and obsolete," considering that monthly pension distributions had failed to keep pace with inflation and that the system left certain social groups such as farm and domestic workers

\footnotetext{
${ }^{2}$ USW Convention Proceedings, 1948, 163-164; Per Inflation Calculator by Cal Stephens $\$ 1638.00$ in 1948 is equivalent to $\$ 16,572.84$ in 2017.

${ }^{3}$ Edward D. Berkowitz, America's Welfare State: From Roosevelt to Reagan (Baltimore: Johns Hopkins University Press, 1991), 39-65.

${ }^{4}$ Berkowitz, 56.

${ }^{5}$ Berkowitz, 54 .
} 
ineligible for benefits. Thus, Murray Latimer declared before the 1948 convention that the old age pension system, "provides benefits in such small amounts and under such conditions that only those who can work no longer will take it when they are forced out of employment." ${ }^{\prime 6}$

Beyond public assistance, many steelworkers were familiar with and often had, some form of a company pension. However, steel companies frequently reduced the monthly benefits under these welfare capitalist schemes by the amount a retiree received in public benefits. US Steel was notorious for this practice. For example, their pension policy stated:

The Pension Rules of the United States Steel and Carnegie Pension fund provide that if any employee is, shall become, or upon application would be entitled to any annuity, pension, or payment of similar kind by reason of any federal or state law (referred to as 'public pension'), any pension which may be granted or paid to such employee under the Pension Rules shall be reduced by a sum equal to the amount of the public pension. ${ }^{7}$

The case of retired steelworker Andrew Girasek offers a stark, but "typical" example of the public-private pension inadequacies faced by older workers before 1949. Girasek, born in Czechoslovakia, immigrated to the United States in 1902 and settled in Pittsburgh. He worked for various subsidiaries of US Steel for 44 years finally retiring in 1946. During WWII, Girasek's son was killed in action in the European theater. ${ }^{8}$ By all measures, Girasek and his family had faithfully served his employer and his nation. However, upon retirement, Girasek received a letter from US Steel that stated, "Wish to advise you that we are in receipt of advice that [a] Pension has been granted you, effective October $1^{\text {st }}, 1946$ in the amount of $\$ 35.00$ of

\footnotetext{
${ }^{6}$ USW Convention Proceedings, 1948, 163-164.

7 "H.A. Shultz, Manager, United States Steel and Carnegie Pension Fund, Pittsburgh, PA, February 1947 to Mr. Andrew Girasek" reprinted in "A Typical Case: U.S. Steel Pension is 29 cents for 44-Year Veteran; "Enjoyable Retirement is Corporation's Farewell Wish," Steelabor, August 1947, 4.

8 “A Typical Case: U.S. Steel Pension is 29 cents for 44-Year Veteran; 'Enjoyable Retirement is Corporation's Farewell Wish," Steelabor, August 1947, 4.
} 
which $\$ 0.29$ will be the Corporation's portion." 9 Furthermore, the letter declared, "May we also take this opportunity to wish you many enjoyable years of your retirement."10

At first glance \$0.29 might have seemed to Girasek a misprint; however, the math worked out as follows: Girasek was eligible for a monthly Social Security old age pension of $\$ 34.71$, and a private monthly US Steel pension of $\$ 35.00$ for ten years. As mentioned earlier, US Steel's pension policy allowed for the subtraction of Girasek's public pension from the company's pension obligation, which ultimately yielded $\$ 0.29$. Furthermore, US Steel's policy was to pay in one lump sum any pension that amounted to $\$ 5.00$ a year or less. Consequently, Girasek received a single payment of $\$ 35.00$ from the company as a pension paid in full. The absurdity of this situation was not lost on the union, which sarcastically quipped in Steelabor, that this Goldstar father, after 44 years of service to US Steel, received a paid in full pension from the company that amounted to one month's grocery bill. ${ }^{11}$ Beyond the $\$ 35.00$ lump sum payment, Girasek and his wife were left to live on a small monthly Social Security check of $\$ 34.71$, which did not even cover the couple's monthly rent. ${ }^{12}$ Ultimately, Girasek, like thousands of other steel retirees before 1949, were the victims of an insufficient public social welfare system as well as a private welfare capitalist system that was arbitrarily managed and utterly void of a worker's voice.

\footnotetext{
9 “Carnegie-Illinois Steel Corporation, US Steel Corporation Homestead Steel Works, Works Auditor to Mr. Andrew Girasek" reprinted in "A Typical Case: U.S. Steel Pension is 29 cents for 44-Year Veteran; 'Enjoyable Retirement is Corporation's Farewell Wish,” Steelabor, August 1947, 4.

${ }^{10}$ Ibid.

11“'A Typical Case: U.S. Steel Pension is 29 cents for 44-Year Veteran; ‘Enjoyable Retirement is Corporation's Farewell Wish," Steelabor, August 1947, 4. (the \$35.00 lump sum payment was derived as follows: Girasek was eligible for a $\$ 0.29$ monthly company pension after the company deducted his social security payment from the company's $\$ 35.00$ monthly liability. Thus $\$ 0.29$ x 12 months $=\$ 3.48$ a year x 10 years (the total life of the pension) $=\$ 34.80$ rounded up to $\$ 35.00$. Girasek for 44 years of service thus received a one-time payment from US Steel of $\$ 35.00$. (Per Inflation Calculator 2017 by Cal Stephens; $\$ 35.00$ in 1946 was equivalent to $\$ 436.31$ in 2017 dollars) ${ }^{12}$ Ibid.
} 
The problem of forced retirements continued past the first wave of layoffs in 1946. By 1948 an increasing pool of older workers were facing Girasek's plight as Inland Steel had forceretired over 400 workers since 1946, and in 1947 alone, US Steel had dumped roughly 2000 older workers out into society with small pensions accompanied by hollow well-wishes for “enjoyable" retirements. ${ }^{13}$

The developing retiree crisis in April 1946 ignited formal calls for increased long-term security at the union's May 1946 convention. Prior to the convention, the USWA received approximately twenty resolutions from locals calling for the union to look into instituting group insurance. The convention's resolutions committee studied the various resolutions and distilled them into "Resolution 38 on Group Insurance." The body of resolution 38 focused on the inadequacies of the many employer-provided insurance schemes throughout the industry and argued that steelworkers first and foremost needed a formal voice in the operation and oversight of such plans. Resolution 38 declared, "there are many outstanding plans for group insurance now in practice in the steel industry in which the steelworkers have no voice in their administration or adequate information thereon; and under many of such plans the employees, when retired by the company, have insufficient funds to continue their payments of such group insurance." Due in large part to the current retiree crises, which had shown a spotlight on the inadequacies of one-sided welfare capitalist security programs, the resolution demanded that the Executive Board "investigate this entire subject to ascertain whether a form of group insurance can be initiated that would more adequately and effectively protect the interests of our membership."14 The evidence is substantial that the impetus for such a policy was driven from a combination of top-level leaders dealing with the fluctuating social and economic realities of the

\footnotetext{
${ }^{13}$ USW Convention Proceedings, 1948, 164-165.

${ }^{14}$ USW Convention Proceedings, 1946, 197-198.
} 
postwar era as well as from the rank-and-file as the retiree crises made blatantly obvious the inadequacies of welfare capitalist group insurance schemes that were arbitrarily managed and lacked the democratic voice of the worker.

Resolution 38 generated much discussion on the floor of the convention. For instance, Delegate Russo of Youngstown Local Union 1330, one of the twenty local unions that had submitted resolutions to the convention, argued that the current company provided group insurance plans were "no good to any of us." ${ }^{15}$ Appalled by the practice of arbitrary old age dismissals, he demanded the union fight for, "a paid up policy at the age of 65 , and... a paid up policy upon disability of any employee, regardless of age."16 Delegate Ortolona of Local Union 1229 suggested the union contemplate a specific life insurance policy used in Allenport, Pennsylvania. At that plant, the workers had a company provided life insurance plan through General American Life Insurance Company, which provided a thousand dollars for the beneficiary. On top of that, the workers themselves created a voluntary plan whereby those agreeing to join had the company deduct 50 cents from their pay in the event of a worker's death. All the monies collected went to the beneficiary on top of the company's $\$ 1000$ life insurance benefit. Ortolona suggested that such a plan could be instituted throughout the industry and possibly increased to $\$ 1.00$ per person on a voluntary basis. ${ }^{17}$ Ortolona's plan highlights the rankand-file's desire to institute better forms of group insurance; however, local union suggestions rarely offered comprehensive policy proposals that included pensions and a broad social insurance plan, which the union could establish across the steel industry. Moreover, voluntarily financed plans such as Ortolona's, although cooperative and communal, would never get

\footnotetext{
${ }^{15}$ Ibid, 198.

${ }^{16}$ Ibid.

${ }^{17}$ Ibid.
} 
significant traction while Murray was president of the union. Instead, Murray, influenced by his Social Catholic philosophy, always maintained that employers had a moral and ethical responsibility for the long-term security interests of their employees, and thus should be required to pay the entire security bill.

Other members of the convention also spoke in favor of Resolution 38. Delegate Blake of Local Union 1014 declared before the convention that he, like many of those present, was "in wholehearted accord with this resolution in essence, and as far as it goes," suggesting further that the union look into a union-run group insurance policy. ${ }^{18}$ Delegate Parker of Local Union 65 gave his opinion on private group insurance noting, "I believe it is a good investment and I believe everybody should provide all the insurance they can afford." ${ }^{19}$ However, Parker particularly disliked the arbitrary administration of many of the company provided insurance plans. For instance, he told the convention that the company he worked for had recently increased the worker's life insurance policy by $\$ 500$ and began deducting more money from the workers' paycheck. This was especially troubling for Parker because of the postwar reduction in hours; however, Parker and his fellow workers had no say in the company's decision to increase the monthly payment. ${ }^{20}$ Ultimately, Resolution 38 "was carried" rather than passed unanimously, which suggests the union may not have been in lock-step over the issue. ${ }^{21}$ But the 1946 convention highlighted that many rank-and-file members had a long connection and understanding with welfare capitalist insurance schemes, and requested that the union use its collective economic power to institute better group insurance programs that interjected the worker's voice into the administration and oversight of those plans.

\footnotetext{
${ }^{18}$ Ibid.

${ }^{19}$ Ibid.

${ }^{20} \mathrm{Ibid}$.

${ }^{21}$ Ibid.
} 


\section{Acknowledging the Rank-and-File's Call for Better Forms of Private Security}

At the June 1946 International Executive Board meeting (IEB), Philip Murray made the issue of private group insurance a focal point believing the "matter... of such importance to warrant at least some real discussion with the board here." 22 Murray understood that the union's ability to bargain for a comprehensive group insurance plan would be a difficult task and that to do it appropriately the union needed better information. Consequently, Murray suggested that IEB create a special committee to study the issue of private pensions and social insurance. ${ }^{23}$

The union's general Counsel Lee Pressman proceeded to offer suggestions on how the special committee should approach the issue. First, he noted that the Department of Labor had already been hard at work collecting data on the type and number of employer-provided plans in existence throughout the country. Pressman advised the USWA social insurance committee to "not merely get reports that they have put out but also all the information that the Department has that went into the making of the report." ${ }^{24}$ Second, Pressman suggested that the committee seek out Dr. I.S. Faulk, of the Social Security Administration, and ask for his counsel on the issue of private group insurance. Faulk, according to Pressman, had been a critical figure in the shaping of the Wagner-Murray-Dingell Bill, and he noted that in previous discussions that Faulk "would be delighted to work with our Union in getting up the material that he can." Information gathered from Faulk could "lay a basis for any plan that we may have in mind for presentation to the steel industry." 25 Finally, Pressman recommended that the committee contact the group

\footnotetext{
${ }^{22}$ IEB, June 24-29, 1946, Box 42, Folder 12, 42.

${ }^{23}$ Ibid, 41-42.

${ }^{24}$ Ibid, 45.

${ }^{25}$ Ibid, 46.
} 
insurance planning firm used by Sydney Hillman and the American Clothing Workers Union $(\mathrm{ACW}){ }^{26}$

After Pressman concluded, Murray opened the floor to other members of the board. David McDonald stated that since the union's inception, many local union leaders had been consistently requesting some form of group insurance in their bargaining sessions. "In every collective bargaining conference with the United States Steel Corporation this subject of group insurance has arisen" McDonald declared, and "it has usually been brought to the attention of the conferences by some member of the Negotiating Committee on the union's side. That member is usually a Local Union President."27 Typically, the company's response was that if the union wanted to run their own plan they could; however, the union had always chosen not to pursue their own group insurance plan, "realizing full well the tremendous job involved in that sort of situation." 28

To McDonald, there was "no question in our minds but this is a pressing problem. The membership wants something; they don't know what they want exactly, but they do want something and some better form of insurance than they now possess." ${ }^{29}$ McDonald suggested that the designated committee on group insurance consult with those USWA district directors who had already successfully bargained at the district and local levels for various forms of social insurance. ${ }^{30}$ For example, I.W. Able had been successful in negotiating with the Timken Roller Bearing company in Canton, Ohio for "a $\$ 1500.00$ death benefit" as well as, "sick benefits" for Timken workers. ${ }^{31}$

\footnotetext{
${ }^{26} \mathrm{Ibid}, 46-47$.

${ }^{27}$ Ibid, 49.

${ }^{28}$ Ibid.

${ }^{29}$ Ibid, 52.

${ }^{30}$ Ibid.

${ }^{31}$ Ibid, 57.
} 
McDonald also suggested that the union had to consider how pursuing private forms of social insurance would impact the union's effort to expand the social security system in the form of the Wagner-Murray-Dingell bill. He noted that in the union's pursuit of private security attention might be pulled from the effort to expand social security. With that possibility lingering in the air, McDonald stated, that he believed the union should still proceed in its effort to bargain for security but, "at the same time we should not leave up our pressure on the WagnerMurray-Dingell Bill." 32 Indeed, the USWA never gave up hope for the passage of the WagnerMurray-Dingell bill; however, as will be evident, the political climate of the late 1940s proved a barrier to the bill's enactment.

The IEB also discussed the possibility of establishing a union-run insurance program. District directors James Robb and James Thomas spoke up against the idea. ${ }^{33}$ USWA vice president Van Bitter also was against it, and similar to Murray, believed that any insurance program the union bargained for needed to be fully financed by the company. ${ }^{34}$ Although Bittner was supportive of trying to expand the Social Security system he remained severely skeptical of Congress's ability to pass the Wagner-Murray Dingell bill, and thus, fell back on the efficacy of bargaining. "I agree with the Secretary-Treasurer here" Bittner announced, noting:

I am not worried about what the effect of anything we may do in collective bargaining will have upon the social security policy of the government, because I will be frank with you, while I intend along with the rest of you to press for general social security from the government through law, I would far sooner have social security brought to our people through collective bargaining where our Union has at least as much to say about what that social security shall be as the employer. ${ }^{35}$

\footnotetext{
${ }^{32}$ Ibid, 53.

${ }^{33}$ Ibid, 57.

${ }^{34}$ Ibid, 58 .

${ }^{35}$ Ibid, 58-59.
} 
Bittner believed that the sentiment for private social insurance from all levels of the union was strong and that he preferred that the union pursue long-term security through "collective bargaining."36

By the end of the IEB session, the board gave its unanimous support to the establishment of a committee to study the issue of private social insurance. Philip Murray then selected David McDonald, Clint Golden, Lee Pressmen along with Directors A. F. Kojetinsky, James Robb, James Thomas, William Hart, and Vice President James Thimmes to comprise the committee. ${ }^{37}$ The process of studying the social insurance issue and crafting a comprehensive private social insurance bargaining strategy would prove to be a long and arduous process that played out from 1947 to 1949.

\section{Bargaining: A Step Toward Private Security}

In 1946 John L. Lewis and the UMW struck the coal operators to win a pension and healthcare system to replace the low quality and paternalistic company doctor system. Lewis, unlike Philip Murray, had completely abandoned any connections to a "labor liberal" postwar agenda and an interventionist federal government. Indeed, as seen in Lewis's performance at Truman's Labor Management Conference, Lewis had extolled the virtues of the free enterprise system and further conceded to employers their right to manage the enterprise and make investment decisions over the adoption and implementation of job killing technology. ${ }^{38}$

Lewis approached the establishment of a pension and social insurance system differently than most industrial unions. Rather than opting for an indemnity insurance model of coverage,

\footnotetext{
36 Ibid, 59-60.

${ }^{37}$ Ibid, 65.

${ }^{38}$ Richard P. Mulcahy, Social Contract For Coal Fields: United Mine Workers Welfare \& Retirement Funds, (Knoxville: University of Tennessee Press, 2001) 2-10; Louis Stark, "Lewis and Murray, Clash Over Wages at Labor Meeting," New York Times, November 9, 1945, 1,3.
} 
Lewis demanded the establishment of a UMW Pension and Healthcare Fund financed by a 5-cent royalty per ton of coal. Moreover, the Fund had a tripartite board of administration that Lewis was able to control and dominate by making himself the UMW trustee, and his loyal friend Josephine Roche, as the neutral third-party trustee. ${ }^{39}$ The Fund thus offered pensions and prepaid noncontributory healthcare to UMW miners. The Fund also used its resources to build and operate a series of regional hospitals and clinics throughout coal country. However, by the mid-1950s the hospitals began to strain the financial resources of the Fund and the UMW began to divest from their hospitals in the $1960 \mathrm{~s} .{ }^{40}$

From its inception, the financial basis for the Fund was built on a bed of shifting sand. Although Lewis secured an agreement from the operators to pay 5-cents per ton of coal royalty, Lewis also accepted management's right to introduce new mining technologies that would go on to eliminate hundreds of thousands of mining jobs. Richard Mulcahy also found that the Fund "was constantly bedeviled by the coal industry's decline after 1948."41 Lewis and the UMW were one of the first industrial unions to opt for a private social insurance plan in the immediate postwar era. Although the steelworkers from 1946 to 1949 would give consideration to the model of private insurance developed by Lewis and the UMW, the USWA would gravitate toward an indemnity-based insurance model, which itself would be plagued by many deficiencies and medical cost overruns throughout the 1950s and into the 1960s.

In an effort to bargain for its own pension and social insurance plan the USWA committee on social insurance immediately set to work to gather as much information about the varieties of private social insurance already in existence throughout the steel industry. To do

\footnotetext{
${ }^{39}$ Mulcahy, Chapter 2.

${ }^{40}$ Mulcahy, 54, 78.

${ }^{41}$ Mulcahy, 32.
} 
this, the union conducted their own internal surveys and partnered with the Social Security administration to gather data. At the October 1946 IEB, David McDonald requested that each district director complete a survey describing the social insurance plans already in existence in their districts, stressing to the directors that the survey would ensure that the union's bargaining strategy will not be "less in contrast than some plan which may be in effect at some steel company or some fabricating company."42 McDonald noted that social insurance experts at the Social Security administration were, "at work digging up information," on the current social insurance landscape in steel. All of the information provided by the district level surveys and the Social Security administration would be used to develop a social insurance bargaining strategy for $1947 . .^{43}$

Throughout much of the union's preliminary efforts to craft a comprehensive pension and social insurance plan, the private insurance industry made attempts to contact the USWA's social insurance committee and offer advice and counsel. David McDonald warned that the insurance industry had caught wind of the Steelworker's intention to bargain for security and had "interested themselves gratuitously into this general thinking and in this idea." 44 He had "received...about a dozen letters from insurance brokers or from bankers or other people who claim to be experts in this field," noting that "all of those things will be examined in due course by our committee." ${ }^{45}$ McDonalds observations are thus in line with Jennifer Klein's argument, that the insurance industry actively sought to promote and market private social insurance to American industry and union's alike. However, USWA leaders were not impetuous in latching

\footnotetext{
${ }^{42}$ IEB, October 1-4, 1946, Box 42, Folder 14-15, 142-143.

${ }^{43}$ Ibid, 143-144.

${ }^{44}$ Ibid, 145.

${ }^{45}$ Ibid, 145.
} 
on to any particular insurance scheme and kept insurance industry representatives at a distance as they studied their options. ${ }^{46}$

In early January 1947, the USWA entered into contract negotiations with US Steel. Philip Murray and the USWA wanted to pursue another wage increase as well as interject into the negotiations the demand for an employer-funded social insurance program. The union and the company met a series of times throughout January. ${ }^{47}$ According to Murray, unlike 1946, the company appeared more accepting of the union's demand for a wage increase. At the third meeting between Murray and Ben Fairless, the union came away believing that the company was open to 21 cents an hour wage increase minus portal to portal pay for USWA miners. However, Portal to Portal pay at that time became an issue temporarily halting a deal. As 1947 negotiations got underway, the courts had yet to rule on the portal to portal case, which dealt with over $\$ 597,000,000$ in claims. Before US Steel would finalize a contract, the company wanted the portal to portal case settled. Consequently, at the fourth meeting between Murray and Fairless, Fairless requested the union accept a contract extension to April 30, 1947, with the hope that the courts would have made a judgment in the case.

Murray believed the company's request to be sincere and accepted, aware that another strike in 1947 would be costly for the union, especially "in the face of a very devastating and altogether unreasonable public opinion." ${ }^{48}$ He also worried about how a strike might play in Congress, which at that time was looking to pass anti-labor legislation designed to weaken and amend the Wagner Act. ${ }^{49}$ Murray's cautiousness was influenced by the negative public response

\footnotetext{
${ }^{46}$ For a look at the insurance industry peddling private welfare options to private organizations see Klein, For All These Rights, 2003, 27, 248-49.

${ }^{47}$ IEB, January 24, 1947, Box 43, Folder 1, 4.

${ }^{48}$ Ibid, 14.

${ }^{49}$ Ibid, 16.
} 
to the 1946 strike wave. After the Republican's and conservative Southern Democrats took over Congress in the 1946 election the union faced a Congressional body unreceptive to the CIO's postwar progressive agenda and anti-labor forces looking for ways to halt the continued advancement of the US labor movement and ultimately weaken it to the point of ineffectuality. With this context weighing him down, Murray believed that another strike in 1947 might only work to exacerbate the further erosion of public support for labor emboldening the anti-labor movement. ${ }^{50}$

Negotiations between USWA and US Steel continued throughout March and April, culminating with a deal reached in the early hours of April 20, 1947. ${ }^{51}$ Both sides were able to agree to a 16 cent an hour package with a 12.5 cent an hour across the board wage increase. The 12.5 cents an hour was on top of wage inequity adjustments. ${ }^{52}$ Not only was the contract a victory for the union's long effort to bring the southern rate closer to the northern rate, it also included a host of other improvements. The contract included a severance pay plan, vacations for new employees, increased safety measures and safety equipment financed by the company, as well as three weeks' vacation for steelworkers with 25 years of service (10 percent of the steelworker population was eligible for this benefit in 1947). Moreover, the 1947 contract extended maintenance of membership, the dues checkoff, and an assessment checkoff of up to 2 dollars. All provisions of the contract were retroactive to April 1, 1947. The contract also included a no-strike pledge and was set to expire on April 30, 1949, however, the union could reopen the contract on wages in $1948 .{ }^{53}$

\footnotetext{
${ }^{50}$ On the postwar Republican upsurge see Nelson Lichtenstein, Labor's War at Home: The CIO in World War II (Philadelphia: Temple University Press, 2003), 230, 238-39.

${ }^{51}$ IEB, April 20-21, 1947, Box 43, Folder 2, 6-9.

52 Ibid, 11-12.

53 Ibid, 13-16.
} 
Lastly, the contract opened the door for the union to bargain for pensions and social insurance in the future. Indeed, throughout 1947 negotiations the union demanded a social insurance plan amounting to 3.5 cents per hour per employee. The company would not agree to a plan; however, the company "did agree that they had an interest in the matter." Given that interest, the company agreed to establish a joint US Steel/USWA committee to study the issue of social insurance. ${ }^{54}$ Murray viewed the company's request as a positive step forward noting, "It is a new idea. It is a virtual acceptance of the idea, and out of this study we hope to be able to effectuate an agreement." 55

The 1947 contract also brought a bit more clarity to the issue of forced retirements. While the managerial clause of the contract would remain the same, Lee Pressman believed that the corporation would end the despised practice at least until the joint US Steel/ USWA social insurance committee could study the social insurance issue. Pressman, however, stressed that there was still the potential that the steel industry might continue the practice of forced retirements, and in that event, the union would continue to file unfair labor practices suits against the industry. ${ }^{56}$

At the IEB meeting, US Steel Negotiating Committee Member, Alex McJannett stated his pleasure with the decision not to strike. He believed a strike would have been devastating for returning servicemen, who according to McJannett, “don't have a dime, and they were fearing a strike." ${ }^{\prime 57}$ Furthermore, considering the union did not mobilize its economic power, McJannett believed the contract to be sound stating, "it is beyond my greatest hopes, and I do sincerely

\footnotetext{
${ }^{54}$ Ibid, 16-17.

55 Ibid, 18.

56 Ibid, 33.

${ }^{57}$ Ibid, 119.
} 
believe that this is the best contract and greatest step forward that we have ever made as members of this organization." 58

Murray closed the IEB noting that US Steel "has made this agreement voluntarily, and it forebodes not evil, but good—good for the industry and good for the union." Moreover, the contract created, "a pattern that other industries can take up and adopt, providing for internal economic stability and good, decent, sound relationships between management and labor in the United States for the next two years."59 For Murray, the 1947 contract closely modeled his cooperative labor-management philosophy. In 1947 the steel industry was not looking for a fight, and thus, Murray was not seeking to make a fight. Murray hoped that such an amicable relationship could continue into the future, declaring that the 1947 agreement, "will be hailed. I hope, in the public prints and even by our enemies as perhaps the most distinct contribution made toward the stability and sound, decent, labor-management relationships in the United States since the end of the world war."60 Although cooperation characterized 1947 bargaining the contract did not symbolize an end to class conflict as anti-labor forces throughout the postwar era mobilized their political and economic power to redefine labor law via the June 1947 TaftHartley Act. Moreover, the cooperative spirit of labor and management witnessed in 1947 with the creation of the joint US Steel/USWA committee on social insurance, would become conflict ridden as management and labor clashed in 1948 and 1949 over the structure, financing, and control of private social insurance.

Many historians have argued that the immediate postwar era into the 1950s was markedly different from the labor-management relationship of the past. The new era was built around

\footnotetext{
58 Ibid.

${ }^{59}$ Ibid, 131-132.

${ }^{60}$ Ibid, 132.
} 
mutual recognition and collective bargaining and lacked the destructive and deadly labor confrontations of the past. Consensus era scholars have pointed to the advancement in the standard of living wrought by strong postwar contracts such as the ones the steelworkers obtained in 1947, 1949, and throughout the decade of the 1950s, as well as the gains made by autoworkers in the UAW's 1950 victory over GM dubbed the "Treaty of Detroit." With contracts such as these many scholars argued that a new era of labor-management cooperation and mutual respect had been achieved and that class conflict had been assuaged. ${ }^{61}$ On a surface level, the postwar era does seem to be a new era of cooperation for labor and management allowing for the manifestation of postwar affluence and the expansion of the middle-class. However, beneath the façade of cooperation lay the sinister seeds of class animosity, the rights of private property, and the desire of the capitalist class to dismantle and destroy the labor movement and the progressive ideals it stood for. Moreover, as New Left scholars have pointed out, the postwar growth of labor such as the UAW and the USWA, although successful in wielding its economic power at the bargaining table, became large bureaucratic institutions that lost touch with the rank-and-file, restricted union democracy, and by the mid to late 1970s became increasingly ineffective at bettering the lives of their members and the larger American public, in the face of global competition, outsourcing and offshoring, the decline of postwar liberalism, and technological displacement. ${ }^{62}$

\footnotetext{
${ }^{61}$ See David Brody, Workers in Industrial America: Essays on the Twentieth Century Struggle (New York: Oxford University Press, 1993) Chapters 5 and 6.

${ }^{6}$ See Nelson Lichtenstein, The Most Dangerous Man in Detroit: Walter Reuther and the Fate of American Labor (New York: Basic Books, 1995); Nelson Lichtenstein, Labor's War at Home: The CIO in World War II (Philadelphia: Temple University Press, 2003); for an account of a radical rank-and-file movement subsumed and marginalized by the development of large bureaucratic unionism see Staughton Lynd, "The Possibility of Radicalism in Early 1930s: The Case of Steel," reprinted in James Green, ed., Workers' Struggles Past and Present: $A$ "Radical America" Reader (Philadelphia: Temple University Press, 1983); for a critique of the New Left thesis that calls for a new "postliberal revisionist" approach to history of the U.S. labor movement see David Brody, "The CIO After 50 Years: A Historical Reckoning," Dissent (Fall 1985): 457-471.
} 
The New Left offered a strong and convincing critique of the failures of the postwar labor management accord and the rise of bureaucratic unionism, however, leveling a disproportional amount of blame on union leaders and bureaucracy. Indeed, the USWA like the UAW, although large and bureaucratic, never abandoned their progressive agenda and when politically and socially feasible they pushed for progressive government legislation in the postwar era such as that found in Lyndon Johnson's "Great Society." ${ }^{63}$ Moreover, it must be stressed that the historical development of globalization and deindustrialization were not something that most industrial leaders foresaw. Rather, forged from the bloody confrontations with monopolistic capital from the end of the U.S. Civil War up to the end of WWII, Murray believed that labor had to match the size and power of capital in order to compete on a more equal footing with large industry. And, although the USWA was not a decentralized democracy, it nonetheless was modeled on the representative democratic structure of the U.S. government. Initially, this model proved dynamic and extremely beneficial for American workers from the 1930s to the mid to late 1970s. In addition, as has been seen throughout this text in the form of IEB debates, the union hierarchy was concerned with and responsive to the opinions and demands of rank-and-file members, in particular their demand for better and increasing forms of private social insurance. The bureaucratic nature of the postwar era was effective in raising working class power vis-à-vis the capitalist class and greatly advanced the material condition of postwar society.

However, Murray's "power through size" unionism did not presume that fundamental change in class relations was needed. Thus, absent a legitimate voice over the managerial investment decisions made in corporate board rooms, even the largest, most powerful, and most dynamic labor unions eventually foundered on the shoals of capitalist power, the remnants of

\footnotetext{
${ }^{63}$ See Boyle, The UAW and the Heyday of American Liberalism, 1945-1968.
} 
which we are living with today. The importance of history is that it allows contemporary society to contextualize their present situation and hopefully make better and more informed decisions. No matter the eventual failures of the labor movement, the labor philosophy of Philip Murray was itself built from historical context and the experiences of his life as a labor leader. Flawed as his philosophy might have been, Murray's decisions were made sincerely and with a crusading spirit to better the lives of American workers. However, Murray's ideals were often tempered by the social and political environment of the war and the immediate postwar era as well as by the demands of the rank-and-file. Beyond the retiree crises that manifested in 1946 the union thus had to navigate the rise of conservative anti-progressive politics and the political minefield of postwar anti-communism.

\section{Communism, Postwar Political Realities, and The Taft-Hartley Act}

One issue that increasingly impacted the union's quest to bargain for private group insurance was the issue of communism. Just before the union's 1946 convention, a few district directors requested that the IEB discuss how to approach the communist within the organization. District director Frank Burke noted that throughout the 1946 strike, labor's adversaries had liberally used the moniker of "communist" to attack the union as something un-American in order to discredit the union in the eyes of the public. Burke told the board that the FBI had been conducting investigations and surveillance of suspected communist members in his district. $\mathrm{He}$ was frustrated by the FBI's activity, not because he held any sympathy for communists, but rather, he felt that such activity was tarnishing the union's image. Burke thus believed the time had come for the union to begin to deal with the communist issue and he called on the IEB to pass a resolution laying out the union's position on communism. ${ }^{64}$

\footnotetext{
${ }^{64}$ IEB, April 1-2, 1946, Box 42, Folder 10, 103-107.
} 
Director William Hart of District 19 argued that anti-labor efforts to paint the CIO as communist was a massive problem for the labor movement. Hart informed the board that, "most of our local unions in district 19 have already passed resolutions that they are going to send to the International Office requesting that our Constitution have a clause in there saying that communists, or known communists or members of the communist party shall be denied membership in our union." ${ }^{65}$ Hart also noted that in his district, "we are unalterably opposed to Communism and the influence of communists within any of our unions." ${ }^{966}$ Hart subsequently called on the board to make the issue of communism a point of discussion at the 1946 convention. ${ }^{67}$ As seen in the comments of Hart and Burke the issue of Communism went beyond the USWA board room and consumed the minds of steelworkers at the district and local level.

Philip Murray told the board that ever since he was a young boy he had been, "inculcated with the philosophy of tolerance." ${ }^{98}$ Moreover, Murray spoke up about politics and American political institutions, noting, "I have never had any belief in the philosophy of Communism, although when I make that statement I admit quite frankly that I do not believe too deeply in the roots of present day Democratic or so-called Republican politics." ${ }^{\circ 9}$ Indeed, Murray had reservations as to the efficacy of American political institutions, believing them to be flawed, and he saw the trade union movement as a tool by which the union could help make the American experience better. However, Murray fundamentally believed that American institutions were "the best yet contrived by the mind of man."70 They had "served the people of the country and the nation, down through the years, in more substantial, beneficial respects than has any other

\footnotetext{
${ }^{65}$ Ibid, 109.

${ }^{66} \mathrm{Ibid}, 110$.

${ }^{67}$ Ibid, 109 .

${ }^{68} \mathrm{Ibid}, 151$.

${ }^{69} \mathrm{Ibid}, 152$.

${ }^{70}$ Ibid.
} 
form of government that I know of down through the history of man."71 Thus Murray, a man who did not see the American political tradition through rose-colored glasses, did, however, view American political institutions as the best form of government in an imperfect world. Murray viewed the communist political tradition as inferior to the American political tradition and disliked what he believed to be the one-sided totalitarian nature of the communist party. In addition, Murray's social catholic sensibilities, which viewed communism as a purely godless and materialistic philosophy, made Murray no friend to communism in general or to Communists in the labor movement. ${ }^{72}$

Murray held more of a "pure and simple" understanding of politics and trade unionism. He told the board that, "I don't think that the American trade union movement should permit itself to become beset with political bickering and quarrelings between its members, as to what sort of political philosophy that particular trade union should pursue."73 Murry's philosophy is an important point to consider when understanding his approach to the communist issue. His "pure and simple" approach meant that he disavowed the idea of trade unions being dominated and controlled by political ideologues. Furthermore, he believed the communist party to be just that, a political party loyal to another nation, and pursuing an agenda designed to stifle democracy and free political thought within the US labor movement. Along those lines, Murray told the board that he believed that since VJ day the motivations of communists within the labor movement had changed. He had been personally researching communist publications over the past three months, which led him to believe that the post VJ day strategy of the American

\footnotetext{
${ }^{71}$ Ibid.

72 See essay William Murphy, "In the Beginning Rerum Novarum” in George Weigel and Robert Royal eds., Building the Free Society: Democracy, Capitalism, and Catholic Social Teaching (Washington D.C.: Ethics and Public Policy Center, 1993); and see essay Thomas C. Kohler, "In praise of Little Platoons: Quadragesimo Anno" in George Weigel and Robert Royal eds., Building the Free Society: Democracy, Capitalism, and Catholic Social Teaching (Washington D.C.: Ethics and Public Policy Center, 1993).

73 Ibid, 154.
} 
Communist Party was to capture the leadership of the trade union movement. ${ }^{74}$ His findings troubled him immensely, noting that no one party or entity had a "moral right" to do such a thing. Adding further, "If that is their policy I am going to fight them—-fight them just like I would fight the Catholic Church if it attempted to do this sort of job in the labor movement of America, or a Protestant church, or the Republican Party, the Democratic Party or the Socialist Party - fight them with all of the vigor that I possess.."75 Murray argued that the union belongs to "the dues-paying members," and that, "It is their Union to do with as they see fit, without interference on the part of any outside agency to influence, to control, to dominate, and to elect officers. ${ }^{776}$

Although Murray vowed to fight communists, he advised the board that mere suspicion that a member was in the Communist party should not be used as grounds for removing members from the union. However, he was in favor of the convention passing a resolution keeping communists from reaching the mantle of leadership. One can view Murray's position as contradictory and anti-democratic, but Murray viewed it differently. He believed it justifiable to pass a resolution barring Communists from holding office, because he argued Communists were (1) loyal to the agenda of the Soviet Union and (2) that their politics was inherently antidemocratic. Thus, Murray announced before the board that, "I have no sympathy for any American who yields greater loyalty to another country than he does to his own, no sympathy whatever." 77 Murray proclaimed: "I have a belief in God, a love of country, and a devotion to my Union, and no foreign government comes ahead of America in my estimation—and I don't

\footnotetext{
${ }^{74}$ Ibid, 154-155.

${ }^{75} \mathrm{Ibid}, 156$.

${ }^{76}$ Ibid, 157.

${ }^{77}$ Ibid, 159-160.
} 
wrap the flag around my body when I make that statement." ${ }^{\text {.78 }}$ Murray did not harbor ill will for the Soviet Union, telling the board that Russia's current government was "her business. I wish her well and I hope that" her form of government, "will do much good for the People." ${ }^{79}$ But for Murray the upcoming struggle with Communists in the union was "a survival of the fittest" for the maintenance of an "independent" trade union movement in America ${ }^{80}$

In late June 1947, anti-labor political forces won a significant political victory with the passage of the Taft-Hartley Act. The act was a turning point in the postwar labor-management relationship as it not only cast a spotlight on the rising political power of capital, its enactment would ultimately prove harmful to the labor movement throughout the rest of the century. For the USWA and Philip Murray, Taft-Hartley blatantly highlighted labor's political weakness in the late 1940s and closed the door, at least temporarily, on labor's goal of passing comprehensive public welfare security in the form of the Wagner-Murray-Dingell bill. By the union's 1948 Convention, Philip Murray was intimately aware of the political realities facing the labor movement. He saw before him an intransigent Congress, full of conservative southern Democrats fearful that federal power would destroy their segregated society and radical antiunion Republicans tirelessly working to stifle the gains that organized labor had made since the 1930s. Thus, Murray declared at the convention:

In this year of 1948, it is to be regretted that this country, our Congress and American industry particularly have been delinquent in the performance of their duties and obligations to American workers. There is no hope under existing circumstances of securing from the Federal Congress any adequate social security. The Congress, as it is constituted today, is a hostile and reactionary Congress representing the vested interests, and it is not prepared to give proper consideration to any type of legislation which has for its purpose improved social security benefits for American wage-earners. ${ }^{81}$

\footnotetext{
${ }^{78}$ Ibid, 160.

${ }^{79}$ Ibid, 161.

${ }^{80}$ Ibid, 163.

${ }^{81}$ USW Convention Proceedings, 1948, 161.
} 
Indeed, Murray spent some time describing to the 1948 USWA convention the political position of the labor movement at that time. His analysis was sobering and his response to the issue shied away from third-party alternatives and rested on a call to build up and expand the CIO-PAC. On the third-party option, Murray argued before the convention that the current thirdparty movement was solely a communist movement. He told the convention that neither he nor leaders of the AFL were asked to be a part of the third-party movement, declaring they "were never consulted—nobody talked." Furthermore, he announced that "reports from reasonably authentic sources would indicate or prove that the third party in the United States of America in the year 1948 was brought into being by the Communist party here in the United States. That is a flat, candid, frank statement of fact." 82

Murray declared that a third party would, "divide and confuse and destroy the American labor movement." 83 He announced to the convention, "My friends, it is your duty and my duty to preserve this labor organization of ours against, invasion, against sabotage, against undermining in any form by any group in our jurisdiction. That statement goes for Republicans, it goes for Democrats, and of course it goes for Communists just the same." 84 For Murray, the CIO and the USWA should be free and independent organizations not beholden to any one party or political philosophy. Instead, he argued for the membership to continue to support the CIOPAC, which would support candidates that supported labor; Murray thus declared that "parties may come and parties may go, but the CIO-PAC will live forever." 85

Beyond political power, Murray also viewed the Taft-Hartley Act as a continuing threat to the solvency of the labor movement and a potential threat to American civil liberties. Indeed,

\footnotetext{
${ }^{82}$ Ibid, 16.

${ }^{83}$ Ibid, 17.

84 Ibid.

85 Ibid.
} 
Murray's understanding of the long-term negative consequences of the law drove him and the USWA to challenge the act's constitutionality. Conservative and anti-labor forces designed the Taft-Hartley Act to eliminate and/or weaken the legal rights labor obtained in the Wagner Act of 1935. To do this the Taft-Hartley Act encompassed a host of different provisions. First, the act placed limits on how unions could influence the political landscape. Second, the act increased an employer's ability to file unfair labor practices suits against unions. Third, the act changed the administrative structure of the NLRB, expanding the number of members on the board from 3 to 5. Fourth, the act opened pathways for employers to seek injunctions against labor. Fifth, it allowed individual states to pass "right to work" laws, which were designed to undermine union security. Sixth, the act banned jurisdictional strikes and secondary boycotts. And seventh, the act required union leaders to sign affidavits attesting that they were not members of the communist party. ${ }^{86}$

Immediately after the passage of Taft-Hartley the USWA IEB met to discuss the impact of the act and whether or not the union should sign the Taft-Hartley affidavits to remain eligible for NLRB protection. Philp Murray was not in attendance, having come down with a severe cold caused by overwork from relentless lobbying against the Taft Hartley bill. ${ }^{87}$ In his absence, McDonald presented Murray's policy statement on Taft-Hartley, which placed the blame for the act's passage on both the Democrats and the Republicans. It argued that rather than ensuring postwar security and prosperity the act would ensure the continuation of "the cycle of boom, bust, and mass unemployment." ${ }^{\prime 88}$ In essence, the act was antithetical to the union's progressive full employment agenda. Furthermore, the statement read, "this act is part of the process which

\footnotetext{
${ }^{86}$ Robert H. Zieger, The CIO, 1935-1955 (Chapel Hill: The University of North Carolina Press, 1997), 245-47.

${ }^{87}$ IEB, July 2, 1947, Box 43, Folder 6, 3-5.

${ }^{88} \mathrm{Ibid}, 133$.
} 
resulted in voting out price control, cancelling rent control, destroying workers' rights under the Wage-Hour act, protecting monopolies, ignoring the needs of veterans, crippling our social insurance system and turning over our homeless veterans to the tender mercies of the building and real estate lobbies." The statement concluded that the act worked to destroy the Wagner act declaring that under Taft-Hartley, "no right was too fundamental, no activity of workers too basic, to escape the Act's hatchet." 89

Union general counsel Lee Pressmen provided an analysis of the Taft-Hartley Act. He advised the board that due to the newness of the law there was no way to predict the law's ultimate impact on the union. But, what he did know was that, at its core, the Taft-Hartley Act was anti-union, and he advised board members to "gird their loins for the attack which will definitely come under the Act." 90 Pressman then turned his attention to discuss the potential impact of a few key provisions of the law, especially the law's political clause and its noncommunist affidavits clause. Pressman recounted that under the wartime Smith-Connolly Act labor was barred from direct political contributions. However, the act did allow unions to discuss political issues, endorse candidates through media sources, and print political literature in support of candidates. The Taft-Hartley Act would reduce labor's political voice even further, putting a straitjacket not only on direct political contributions but also the political activities allowed under Smith-Connolly. Pressman went on to argue that such political restrictions were in his legal opinion, unconstitutional. ${ }^{91}$

The impact of Taft-Hartley's non-communist affidavits clause, however, weighed on Pressman. If the union refused to sign the affidavits, it would lose its access to NLRB machinery

\footnotetext{
${ }^{89}$ Ibid, 133-134.

${ }^{90}$ Ibid, 18.

${ }^{91}$ Ibid, 23-26.
} 
and thus legal protection as a labor organization during organizational drives and certification elections as well as in unfair labor practices suits. This was the stark reality facing the union. If they chose to fight Taft-Hartley and forgo signing the affidavits, they lost their legal standing as a union. However, Pressman believed that the writers of the Taft-Hartley law overlooked one crucial aspect: labor's economic power. If a union was organizationally strong like the USWA, it could in theory win both employer recognition and grievances on an independent basis. ${ }^{92}$ However, the law was designed to undo the economic power of organizationally strong unions such as the USWA over the long run. Taft-Hartley posed very troubling times ahead for the labor movement and at the present moment, outside of economic strength, the law gave labor little space to maneuver. Pressman told the board that he and other CIO general counsels had, "come to the same conclusion that we can't possibly see how this machinery can in any sense be workable." He added, "the situation looks hopeless to us lawyers."

For Pressman, Taft-Hartley not only limited labor's ability to seek redress for grievances and hampered labor's ability to organize and grow stronger, more importantly the law, Pressman predicted, would be used by employers to levy unfair labor practices charges on labor unions. ${ }^{94}$ Furthermore, he advised the board to think about bargaining for contract language to hedge against employer abuse of unfair labor practices suits. For example, under Taft-Hartley, the possibility was open to employers to sue the union for an unfair labor practice if just one union member, i.e., a "lone wolf" broke a contract provision. Under this interpretation of the law an employer could theoretically sue a union into submission. Pressman thus declared, "when they start milking the treasury there isn't much protection the union can give to its membership." ${ }^{\prime 95}$

\footnotetext{
${ }^{92}$ Ibid, 55-57.

${ }^{93}$ Ibid, 68.

${ }^{94}$ Ibid, 68-70.

${ }^{95}$ Ibid, 99.
} 
Pressman concluded his remarks declaring to the board that "you are not up against some people who are just simply, a little more conservative in their views than average American citizens." Rather:

You have a situation today that is different in content from anything that we have ever had, because this is the creation of a Government instrument to be used by employers. You are not going to be fighting many employers; it is a Government instrument, and an instrument that is designed and based on a policy which says in so many words, 'weaken, if not destroy, the labor unions themselves.' 96

After some discussion, the USWA IEB voted to approve a resolution that stated the union would not sign the affidavits and thus forgo NLRB protection as governed by the new Taft-Hartley Act. Instead, the union vowed to use its economic strength vis-à-vis employers and work to eradicate Taft-Hartley from the books. ${ }^{97}$ The union's decision was a statement of defiance. However, its moral and ideological objections to Taft-Hartley would, by 1948 and 1949, encounter the forces of reality as the issues of forced retirements and of long-term welfare security made union leaders reevaluate their defiance of Taft-Hartley in order to bring private forms of security to their members in 1949.

\section{The Inland Steel Case and 1948 Bargaining}

When steel companies such as Inland Steel and US Steel began arbitrarily retiring workers at age 65 in 1946, the USWA began filing grievances against the action. The grievances argued that employers were in violation of the seniority and discharge provision of the contract. Employers countered the union's claim arguing that the discharge of older workers was a managerial prerogative. Over time these grievances made their way to the National Labor Relations Board culminating in the Inland Steel Case. Thus, the NLRB was asked to rule on

\footnotetext{
${ }^{96}$ Ibid, 125-126.

${ }^{97}$ Ibid, 127-130.
} 
whether retirement age and pensions and social insurance were subjects of collective bargaining. ${ }^{98}$

In April 1948, the NLRB ruled in favor of the union's position that both retirement age and pensions and social insurance were bargainable subjects. However, the ruling was not a complete victory for the USWA. The board, which was now operating under the Taft-Hartley Act, declared that for the union to be protected by the ruling, it first needed to comply with TaftHartley by signing the non-communist affidavits. Murray and many other union leaders viewed the decision as both a hindrance and a blessing in disguise. First, the ruling officially brought pensions and social insurance into the realm of bargaining. And second, the ruling opened a door for the union to test the constitutionality of Taft-Hartley. Consequently, the union appealed the affidavits portion of the ruling to the Seventh Circuit court of appeals. The steel industry likewise submitted an appeal to the Seventh Circuit court challenging the board's ruling that pensions and social insurance were subject to bargaining. ${ }^{99}$

The Seventh Circuit Court of Appeals gave its ruling on September 23, 1948. The court upheld the NLRB's ruling that retirement age and pensions and social insurance were subject to collective bargaining. However, in a 2 to 1 decision the court upheld the NLRB ruling that stated the union needed to first sign the Taft Hartley affidavits before the board would protect their right to bargaining for pensions and social insurance. ${ }^{100}$ After the ruling, Murray told reporters that he believed the one dissenting vote on the court "demonstrates the serious constitutional issues which [are] involved in the affidavits phase of the case."101 Murray vowed to take the issue to the Supreme Court. Despite not winning the affidavits issue, Murray believed

\footnotetext{
98 "High Court Rules in Favor of USA in Pension Case," Steelabor, May 1949, 5.

99 “Court Upholds USA Right to Bargain on Pensions," Steelabor, October 1948, 2.

${ }^{100}$ Ibid.

${ }^{101}$ Ibid.
} 
the court's ruling, which upheld the NLRB's position on pensions and social insurance to be "a great victory." He noted that, "By judicial decision the court has upheld the long-term position of the union - that pensions and social insurance are matters of collective bargaining."

Moreover, Murray announced:

This decision will have a salutary effect throughout American industry. It will give great legal impetus to bargaining on these issues. Now that the courts have decided, we will expect employers to live up to the decision and negotiate reasonable and substantial plans with the union representing the employees. ${ }^{102}$

Following the court of appeals ruling the USWA next sought to take the case before the United States Supreme Court. Although Murray and many upper level USWA leaders disliked the Communist party, seeing them as anti-American and totalitarian, they believed the TaftHartley anti-communist affidavits provision of the law to be unconstitutional and a long-term threat to the union and the civil liberties of all Americans. Furthermore, the union argued that the affidavits clause was unconstitutional on the grounds that (1) "It violates the guarantee of freedom of thought and speech of the First Amendment to the U.S Constitution;" (2) "The requirements are not narrowly drawn and invade basic rights under the First and Fifth Amendments;" and (3) "They are vague and indefinite and impose tests of guilt by association."103 The Supreme Court would not rule in the matter until May 1949. In lieu of the decision, the issues of bargaining for security and whether or not the union should comply with Taft Hartley became a point of debate and discussion for the union throughout 1947 and 1948. Similar to the 1946 convention, the union's 1948 convention focused on the issue of social insurance but with more intensity. Prior to the start of the convention, the International Union received approximately 27 resolutions from local unions on the issue of social insurance

\footnotetext{
102 Ibid.

103 “Supreme Court Asked for Taft-Hartley Ruling," Steelabor, December 1948, 9.
} 
and pensions. ${ }^{104}$ Moreover, the 1948 convention proceedings highlighted that many delegates were concerned with the issue of pensions and social insurance. For instance, delegate Nathaniel E. Sallie of local 1557, noted his local's pleasure in the pension and social insurance program the union was fighting for in 1948. He said that his local was one of the local unions who submitted a resolution on pensions and social insurance to the 1946 convention because he and the rest of his fellow members had witnessed many older workers forced to retire at the age of 65 with no means of security. "So the cry went up, what are we going to do about these veteran employees, and we are at a loss to find an answer and we decided to send a resolution to the 1946 convention in Atlantic City," he recalled. "I was the author of that resolution and I am gratified today to hear the wonderful talk by President Murray in support of that resolution."105

Delegate Winship of local 1833 represented workers from a small fabricating company called the Worthington Pump and Machinery Corporation. He noted that ever since 1946 the company had taken a hardline stance against local efforts to bargain for social insurance and pensions. However, in 1948, Winship observed that the company had changed its hardline position and now had taken the same position as US Steel on the issue of social insurance and pensions. Thus, Winship recognized the benefits of industry-wide bargaining. He announced his support for the union's effort to bargain for insurance and ended by stating "...we should have a nation-wide program such as the United States Steel Corporation would have with the bargaining agency of the United Steelworkers, as outlined by President Murray."106

Delegate Archie Breen of local union 1010 also spoke on the issue of social insurance and the ongoing retiree crises. Breen represented an Inland Steel local significantly affected by

\footnotetext{
${ }^{104}$ USWA Convention Proceedings, May 1948, 158-159.

105 Ibid, 165.

${ }^{106}$ Ibid, 166-167.
} 
arbitrary forced retirements and he desperately wanted to better the conditions of those retirees. Although Breen was in favor of the union's effort to bargain for security, he was in conflict with the union's defiance of Taft-Hartley. Breen and his local union in 1946 sought a NLRB ruling on the issue of forced retirements, which evolved into the Inland Steel case. He told the convention that he believed the union needed to sign the affidavits, so the union could take advantage of the NLRB ruling. ${ }^{107}$

Breen however noted that he did not speak for the entire local. In fact, he informed the convention that his local was very divided on the issue: "I want you to know we had a bitter argument on the floor of our union."108 Still, he wished the union would sign the affidavits declaring, "I feel a heart-felt responsibility to them [the forced retired steelworkers]. Sure, the President of our union says, 'Well, even if you sign a non-communist affidavit, you haven't won your grievance: No, but we can't win our grievance unless we comply."109 Thus for Breen, and those who thought like him, the union's defiance of Taft-Hartley was standing in the way of addressing the immediate needs of older workers.

A few weeks after the Steelworkers' 1948 convention, the USWA IEB discussed the Taft-Hartley affidavits situation and whether or not the union should follow the majority opinion of the convention and sign the affidavits. Murray believed the topic merited consideration given the attention it received at the May convention and he wanted to hear the opinions of the district leaders. ${ }^{110}$ The main issue at hand was whether or not the union's decision not to sign the affidavits was having an overwhelmingly adverse effect on the union.

\footnotetext{
${ }^{107}$ Ibid, 165-166.

${ }^{108}$ Ibid, 165.

${ }^{109}$ Ibid, 165-166.

${ }^{110}$ IEB, June 9, 1948, Box 43, Folder 12, 4-7.
} 
The analysis of the various members of the IEB was mixed. Many discussed how not signing the affidavits made the union vulnerable to employer assaults as well as the threat of raids by rival unions. Even though there were apparent downsides to not signing the affidavits and thus not having NLRB protection, the consensus by the end of the board meeting was to stay the course. I.W. Abel, district director in Canton and Massillon, Ohio, told the board that Timken company, one of the largest employers in the region, was still bargaining with the union despite the lack of NLRB protection. Furthermore, Abel noted that no other union had thus far attempted to challenge the USWA for representation of the Timken workforce and that the Timken company was continuing to abide by maintenance of membership and the dues check-off provision. ${ }^{111}$ Abel noted a surprising change in Timken's traditionally hostile and antagonistic relationship with the union stating that now "They treated us pretty much like human beings this time." 112

Discussing the situation in Chicago, Director Joe Germano revealed that the International Association of Machinists (IAM) had been challenging the union's jurisdiction at a small steel plant located in Aurora, Illinois. ${ }^{113}$ The phenomenon of jurisdictional raiding was not isolated to this small town. Indeed, members of the board described various incidents throughout the country in which rival unions and or employers, or both working jointly, were attempting to take advantage of the union's vulnerable position vis-à-vis the NLRB. For instance, in director A. F. Kojetinsky's district, a district composed of many small steel concerns, there were numerous IAM challenges. He told the board that "I can say in substance that the employer is not quarreling with us about the matter. Our big problem lies in the fact that the Federation [AFL]

\footnotetext{
111 Ibid, 9-11.

112 Ibid, 13-14.

113 Ibid, 39-43.
} 
has been able in these Machinists' groups to make some headway." 114 With respect to new USWA efforts to organize, Kojetinsky informed the board that many employers would not agree to "neutral" judges for union certification purposes. Moreover, Kojetinsky and many other district directors were allowing the UAW to represent their members in NLRB certification elections rather than lose ground to the non-CIO machinists union. ${ }^{115}$

District director James Robb declared, “I haven’t lost any locals or any members because of not having signed the affidavit. However, we have been attacked in several places by the Machinists." ${ }^{116}$ Furthermore, Robb raised concern over the practice of using the UAW to win certification elections. It was his opinion that in the future the USWA might "be faced with raids by that organization." Director Al Whitehouse seconded Robb's statement, declaring that the UAW in his district was "beginning to...put out feelers through the plant and talking about themselves being the only big CIO union that can comply [with Taft Hartley Affidavits provision] and that they will get an election." 117

Beyond the threat of jurisdictional raids, William Burke of District 32 told the board that some companies in his district were becoming openly hostile to the USWA due to its vulnerable position and working with unions such as the IAM in order to defeat the union. Burke stated that “it just so happened while we were urging the employees to vote 'no union' the company seized the opportunity and about two days before the election they put out a two or three page letter extolling the merits of a little private organization where the dues are cheap and where you can control your organization right here in the city of Madison, and gave them the old company

\footnotetext{
114 Ibid, 17.

115 Ibid, 17-18.

116 Ibid, 18.

117 Ibid, 26.
} 
line." 118 Although there were instances of both union jurisdictional raids and employer attacks on the union, the board had mixed opinions on how the union should proceed, that is whether or not the union should comply with the Taft-Hartley law and sign the affidavits. Some board members felt the union should not remain in its vulnerable position; others, especially top leaders such as Murray, McDonald, and Bittner, believed that the long-term effects of the Taft-Hartley law were more important considerations than the immediate consequences of non-compliance.

USWA leaders above the district level approached the affidavits issue from a broader and more strategic point of view. Two crucial issues drove their outlook. First, union leaders were concerned with how, for instance, wage increases would be perceived by the membership and the public if the union signed the affidavits and then secured a wage increase in 1948. USWA Vice President Van Bittner offered the board the most insightful analysis on how signing the TaftHartley affidavits before securing a wage increase would be detrimental to the union. ${ }^{119} \mathrm{He}$ declared, "I remember when the [anti-union] Smith Connolly Act was passed [during the war] and a lot of our people in the office in Washington were saying: 'Well, when the war is over there is going to be a Utopia and all of this will be wiped out."'"120 Obviously the utopia never materialized and the labor movement was now facing an ever more inimical law whose likelihood of repeal was slim to none. Bittner believed that the union had the economic power to secure wage gains in 1948 despite the legal straitjacket the union currently occupied. Moreover, he cautioned the board to consider how signing the affidavits might undermine the public relations optics surrounding the union's economic power vis-à-vis capital. Furthermore, he believed that signing now and then securing a wage increase would taint the relationship the

\footnotetext{
118 Ibid, 32.

${ }^{119}$ Ibid, 57-60.

${ }^{120}$ Ibid, 59-60.
} 
union had with the rank-and-file declaring if wage increases "come just after you agree to comply with the Taft-Hartley Act then our membership is going to take the position that if you complied with the Taft-Hartley Act long ago you would have had increases in wages."121 Ultimately, Bittner cautioned the board against signing the affidavits before the end of 1948 bargaining believing that winning a wage increase on economic power alone would be a significant victory and statement to the membership and the broader public.

Second, and maybe of most importance, union leaders, especially Philip Murray, feared that signing the affidavits, could potentially harm the Inland Steel case which was addressing both the issue of labor's right to bargain over pensions and social insurance, and the issue of Taft-Hartley constitutionality. The US Supreme Court was at that time debating the merits of a "political expenditures" case, which like the Inland Case, was also testing the constitutionality of Taft-Hartley. With regards to the political expenditures case, union leaders were concerned with how the court would view the signing of the affidavits. Leaders thus argued that signing the affidavits prior to a ruling in the political expenditures case might make the court less inclined to rule in the favor of labor. USWA counsel Arthur Goldberg told the board that a major question before the court was, "How much does this [Taft-Hartley Law] actually restrict the right of labor to campaign against the law." 122 In essence, any action taken by the union, for instance, signing the affidavits, that reinforced the idea that labor was functioning within the framework of the law would negate the sense that labor was being harmed by the law, thus emboldening the court to uphold the political expenditures provision within the Taft-Hartley law. ${ }^{123}$ Murray agreed; he believed signing the affidavits "might very well prejudice the Court's mind in making its

\footnotetext{
${ }^{121}$ Ibid, 59 .

122 Ibid, 50 .

${ }^{123}$ Ibid, 50-52.
} 
decision." ${ }^{24} \mathrm{He}$ added, "it appears that [the justices] are having quite a squabble... about the extent to which the Court may go in either upholding Judge Moore's decision or perhaps sending it back to him."125 Thus, Murray cautioned that, "If our organization complied I assume that it might give comfort to those who are for reversal in the Lower Court and have the political provision of the Act stand as they are." ${ }^{\prime 26}$

One of the final leaders to speak on the issue was David McDonald. McDonald advised the board not to sign the affidavits. His argument was based on the idea of viewing the impact of the law not on individual districts as each of the district directors testified to, but instead, considering the ramifications of not signing the Taft-Hartley affidavits as a totality. With an indepth knowledge of organizational statistics, McDonald concluded that "this union in an overall sense has not been hurt. As a matter of fact, this Union has grown important since we took this position." 127 McDonald conceded that there were some organizational setbacks at the district level but informed the board that since 1937 the union organized a total of 182 new locals of which 82 were organized pre-Taft-Hartley, while 100 of the 182 were organized post-TaftHartley. Thus, McDonald declared, "We had a better record since the Taft-Hartley law became effective in the year ' 47 than we did for the period prior to Taft-Hartley." ${ }^{128}$ Furthermore, McDonald noted that total union membership statistics, although volatile from month to month since Taft-Hartley, were higher than in $1946 .{ }^{129}$ In the end, despite the many difficulties district level leaders faced given the unions stance against Taft-Hartley, the strategic and higher level

\footnotetext{
${ }^{124}$ Ibid, 52.

${ }^{125}$ Ibid.

${ }^{126}$ Ibid.

${ }^{127} \mathrm{Ibid}, 61$.

${ }^{128}$ Ibid, 61-62.

${ }^{129}$ Ibid, 62-64.
} 
considerations offered by upper USWA leaders resonated with the board who unanimously voted against signing the affidavits.

\section{Collective Bargaining}

As formal negotiation with US Steel opened in early 1948, the union demanded both a wage increase and the establishment of a pension and social insurance program. With regard to the pension and social insurance program the union demanded the following: (1) a life insurance policy that equaled 18 months of "average wages of the individual" amounting to $\$ 5,400$; (2) a "fully paid-up life insurance policy amounting to $\$ 1,500$," for workers 65 and older; (3) a hospitalization plan amounting to $\$ 8$ dollars a day per employee; (4) \$35 dollars a week sickness pay; (4) maternity care and insurance coverage for dependents; (5) surgical indemnity insurance up to $\$ 225$ dollars for surgical procedures, and (6) a \$150 dollar a month pension for workers 65 and older, as well as an end to compulsory retirements. ${ }^{130}$ Lastly, Murray demanded that the insurance system be run by a tripartite committee to ensure that the union had a voice over the administration of the plan. ${ }^{131}$ Murray Latimer, the union's hired social insurance expert, estimated the cost of the social insurance program to be 9.65 cents per hour and the pension plan to cost 13.5 cents per hour. The total cost of the pension and social insurance was estimated to be 23 cents per hour per employee. ${ }^{132}$

US Steel countered the union's demand with a more limited program. The company offered the following social insurance plan: (1) life insurance amounting to a year's salary, which equated to roughly $\$ 4,000$ dollars; (2) a hospitalization program amounting to $\$ 6$ a day; (3)

\footnotetext{
${ }^{130}$ USWA Convention Proceedings, May 1948, 159.

${ }^{131}$ Historian Alan Derickson highlights that the USWA pushed for a voice over their pension and social insurance plans and were able to achieve that goal more than most other industrial unions, see Alan Derickson, "The United Steelworkers of America and Health Insurance, 1937-1962" in Sally M. Miller and Daniel A. Cornford ed., American Labor in the Era of World War II (West Port: Praeger, 1995) 74-79.

132 Ibid, 159-160.
} 
sickness insurance of $\$ 21.00$ a week; (4) maternity care and dependent coverage; and (5) surgical indemnity insurance of up to $\$ 175$ dollars. Moreover, the companies plan called for joint contributions and company administration. ${ }^{133}$

Murray could not accept joint contributions and company administration. He was a firm believer that the company had a moral responsibility to finance the long-term security of its employees. Often Murray made arguments that industry should at the very least invest in their employees the same way they invested in capital maintenance and improvements. ${ }^{134}$ For instance, before the 1948 convention Murray told the delegates that as of 1948 the steel industry had set aside $\$ 750,000,000$ for capital investments and maintenance, and it was his belief industry should in a similar fashion invest in their employees. ${ }^{135}$

Unlike 1947, 1948 bargaining was filled with tension and acrimony, especially the second to last meeting between Murray and John Stephens of US Steel. After much debate on each side, both he and Stephens came to an impasse on the issue of wage increases and the establishment of a pension and social insurance fund. ${ }^{136}$ As Stephens failed to give ground Murray accused Stephens of being the corporation's "hatchet man." He walked out of the negotiation and, according to Murray, "slammed the door in his face," conducting "a seven-day sitdown," before agreeing to meet with him again. ${ }^{137}$

After the conflictual meeting with Stephens, Murray agreed to meet once more on July 15,1948 , the same day in which the IEB was in session. In the previous meeting Stephens went as far as offering Murray a $12 \frac{1}{2}$ cent per hour wage increase with an extension of the current

\footnotetext{
${ }^{133}$ Ibid, 160.

${ }^{134}$ Ibid, 160-161.

135 Ibid, 161-162.

${ }^{136}$ IEB, July 15, 1948, Box 43, Folder 13, 48-49.

137 Ibid, 48.
} 
contract until April 30, 1950. Stephens's offer also included a provision that would allow the USWA to reopen the contract in July 1949 to discuss wages only. Murray refused the deal because the offer did not include a provision to reopen not only wages in 1949 but also the issue of pension and social insurance. Although Murray declined Stephens's initial offer, the two continued to negotiate. Stephens conceded only slightly on the issue of pensions and social insurance; US Steel offered a 13 cent an hour wage increase for 1948, from which the company would take $2 \frac{1}{2}$ cents and place that into a union-controlled pensions and social insurance fund. Murray told Stephens that his offer was "unacceptable." ${ }^{138}$ He argued that the company should pay for a pension and social insurance fund with monies above and beyond the funds appropriated for wages. Although a deal to establish a workable pension and social insurance plan fell through in 1948, Murray was still successful in securing one of the best wage deals of any union in the country. Even unions such as the UE and the UAW, both of which had NLRB protection as well as the right to strike in 1948, did not do as well. Ultimately, Murray was able to get US Steel to agree to an overall wage increase of 13 cents per hour and the right of the union to reopen the contract in July 1949 to discuss wages as well as pensions and social insurance. ${ }^{139}$

After describing the terms of the deal before the IEB, Murray opened the floor for debate and discussion. US Steel Negotiating Committee member Edwin Lofgren from Massachusetts argued that the union needed to do more in this bargaining session to secure a pension and social insurance deal. Lofgren recounted that ever since April, when contract talks began, he had been telling his constituent members that the reason wage increases did not manifest in April was due

\footnotetext{
${ }^{138}$ Ibid, 11-12.

${ }^{139}$ IEB (Combined Wage Policy Committee Meeting), July 16, 1948, Box 43, Folder 13, 32-33; IEB, July 15, 1948, Box 43, Folder 13, 8 .
} 
in part to the union's effort to secure a pension and social insurance plan. However, Murray's proposal did not include a pension and social insurance plan in $1948 .{ }^{140}$ Lofgren told the board that his members "would rather have that [pension and social insurance] than anything." $141 \mathrm{He}$ added that,

I know that, because of the fact that this would mean more to the oldtimers in our organization who helped build the organization. Any time you talk about an increase in wages you are handing it on to the guys who have been coming in the last two or three years and getting gravy. The fellows that built this Union are getting old and they are retiring without any insurance whatsoever. The one they are paying for now is out the window when they reach 65 . They are paying for the Blue Cross Blue Shield, which costs them about $\$ 4$ a month, and there is absolutely nothing to it when they retire from the Corporation. ${ }^{142}$

Ultimately, Lofgren feared that the window for the union to win a pension and social insurance fund from the company was closing fast, and if the Union did not secure a pension and social insurance deal in 1948, they would never secure one. ${ }^{143}$

Murray attempted to address Lofgren's concerns. He reiterated the fact that he had pressed the issue with US Steel leadership but could not reach a satisfactory plan given the union's 1947 no-strike pledge. Murray told the board that, "I know, I would like to have social insurance and I would love to have pensions." Noting further, "I walked out on little Johny Stephens last Thursday and slammed the door in his face, I referred to him as the Little Hatchet Man, and I told him I didn't care to see him again. Why? Because he refused to agree with me to do anything about pensions or social insurance."144 Despite Stephen's intransigence, and given the union's difficult bargaining position, Murray counseled the board not to overlook the

\footnotetext{
${ }^{140}$ IEB, July 15, 1948, Box 43, Folder 13, 44-45.

${ }^{141}$ Ibid, 45.

${ }^{142}$ Ibid, 45-46.

${ }^{143}$ Ibid, 46.

${ }^{144}$ Ibid, 55-56.
} 
fact that the union (1) had secured for the most part better or equivalent wage concessions from US Steel than did most CIO unions who had the strike weapon, and (2) the union was able to win in writing the right to open the contract in July 1949 for both wages and pensions and social insurance; too include the union's right to strike over both issues. ${ }^{145}$ Murray ended his remarks to the board declaring, "there is one thing that I am sure of, and that is that this organization will have the right, for the first time in its history, to make a contractual issue out of the question of social insurance one year from now, and if it cares to strike about that question it can."146

Upon securing the best contract terms he could muster from US Steel, Murray placed them before the IEB for a vote. Murray justified his bargain by comparing it to the various contracts secured by other CIO unions that retained their ability to strike in 1948. The UE achieved only a 11 cent per hour deal with the ability to bargain over pensions and social insurance in 1950, not 1949. ${ }^{147}$ As for the UAW, after conducting a strike at Chrysler it won only a 13 cent per hour wage increase, and at General Motors it won an "8-cent cost-of-living bonus and a general flat increase of three cents per hour added to the hourly rate."148 Although lacking a pension and social insurance provision, Murray as well as many union leaders from high level staffers, to district leaders, to local union leaders touted the 1948 contract as one of the greatest victories of the union given that the union lacked the strike weapon. Furthermore, Murray believed that the 1948 contract vindicated the union from "leftist" criticism over the union's 1947 no-strike pledge. ${ }^{149}$

\footnotetext{
${ }^{145}$ Ibid, 55-56.

${ }^{146}$ Ibid, 58.

${ }^{147}$ Ibid.

${ }^{148}$ IEB (Combined Wage Policy Committee Meeting), July 16, 1948, Box 43, Folder 13, 19.

${ }^{149}$ Ibid, 16.
} 


\section{Conclusion}

In May 1949 the Supreme Court ruled on the Inland Steel case. The court upheld the Seventh Circuit court's ruling on the issues of social insurance and the Taft-Hartley affidavits. Again, the ruling marked a victory for the union on the issue of pensions and social insurance; however, a defeat in the union's bid to eradicate the Taft-Hartley affidavits clause of the TaftHartley Act. ${ }^{150}$ Thus the union was faced with a dilemma of signing the affidavits to acquire legal protection in their effort to bargain for security or continue to defy the law and rely solely on economic power. As noted earlier, this issue had troubled the union ever since the passage of the Taft-Hartley Act and the union's decision not to comply with it. Indeed, this was a critical issue, especially with regard to the on-going retiree crises. With little hope of securing the political power needed to pass strong public social welfare in the form of the Wagner-MurrayDingell bill, and given the fact that forced retirees were struggling to make ends meet and active rank-and-file members were demanding long-term security, the union by 1949 had to decide whether or not it was in their best interest to continue to defy Taft-Hartley or capitulate and sign the non-communist affidavits as the 1949 bargaining season approached.

150 “High Court Rules in Favor of USA in Pension Case," Steelabor, May 1949, 5. 


\section{Chapter 5: Bargaining for Security: The USWA and 1949 Steel Strike \\ Introduction}

In October 1949, Philip Murray embarked on a speaking tour of basic steel designed to rally support for the ongoing strike to win employer-provided pensions and social insurance. Murray's first stop was Youngstown, Ohio. As he entered the rugged steel city, Murray quickly discovered an outpouring of rank-and-file support. At the official rally held in Wick Park on the city's Northside, Murray spoke to an enthusiastic crowd of over 25,000 steelworkers and their families. Indeed, the pictures of the event show masses of onlookers intently listening to Murray's speech, coming together in solidarity with their union, their community, and the cause of security. ${ }^{1}$

As the speaking tour continued, the enthusiasm displayed in Youngstown proved to be not an aberration but the norm. For example, when Murray arrived in Gary, Indiana over 8000 people filled the Gary auditorium to capacity, while another 7000 stood outside and listened to the event on a public-address system. Moreover, countless others listened to Murray speak over the radio. ${ }^{2}$ In Homestead, Pennsylvania, Murray spoke to a standing room only crowd of 20,000 at Homestead's West Field. ${ }^{3}$ Bethlehem steelworkers proved just as supportive filling Bethlehem High School field to capacity. Bethlehem steelworkers also promoted the cause of security throughout the town by turning an old late model automobile into a rolling billboard plastered with campaign slogans such as "People Like Machines Wear Out" and "Pensions for the Old."

\footnotetext{
1 “25,000 Hear Murray at Youngstown” Steelabor, November 1949, 3; "Murray Says Men Back Union, Police Estimate 20,000 at Park, C.I.O. President Opens Series of Talks Here; Denies Need to Stir Up Enthusiasm" Youngstown Vindicator, October 11, 1949, 34; "Murray Here for First Speech; U.S. Steel Calls New Steel Parleys...Throngs at Park" Youngstown Vindicator, October 11, 1949, 1.

2 "Murray Gets Huge Ovation in Gary!" Steelabor, November 1949, 8.

3 “20,000 Greet USA Leader at Huge Homestead Rally" Steelabor, November 1949, 12.

4 "Bethlehem, Pa. Welcomes Pres. Murray" Steelabor, November 1949, 5.
} 
At the Homestead rally, Philip Murray summed up the essence of the ongoing fight for security declaring, "The steel industry cannot justify before the bar of public opinion its position against non-contributory pensions and social insurance. The true fact is that steelworkers are contributing their blood, their sinews and their lives to the industry. They are going to continue the fight until the steel industry recognizes its obligation to them and their families."5 Murray and the thousands of steelworkers who showed up to hear him speak in the fall of 1949, understood that only solidarity and an unwavering resolve could win the strike and bring forth the pensions and health security they so desperately needed.

Indeed, as we have seen thus far, since the end of WWII the USWA faced a series of events and issues that influenced the organization's decision to seek pensions and social insurance at the bargaining table. In 1946 employers began force retiring steelworkers at age 65 with very little financial security to support them in retirement. This unfortunate event produced a wave of rank-and-file demands on USWA leaders requesting better forms of employer provided welfare security. Moreover, the labor movement's effort to push political leaders to expand the public welfare system and pass national healthcare legislation during the war failed. Similar efforts in the postwar era also collapsed due in part to a Republican and southern Democrat alliance that reshaped the Congressional landscape in 1946. Rather than expanding into the postwar era, the dream of continued progressive reform stalled with the Truman administration. Moreover, the labor movement in the postwar era found itself under assault from anti-labor forces who looked to circumscribe the power of organized labor via the Taft-Hartley Act and the postwar "red scare."6

\footnotetext{
5 “20,000 Greet USA Leader at Huge Homestead Rally” Steelabor, November 1949, 12.

${ }^{6}$ On the postwar "Red Scare" and the rise of McCarthyism see Thomas Patrick Doherty, Cold War, Cool Medium: Television, McCarthyism, and American Culture (New York: Columbia University Press, 2003); Mary L. Dudziak, Cold War Civil Rights: Race and the Image of American Democracy (Princeton: Princeton University Press, 2000);
} 
By 1949 , the USWA understood that the pension and health security that its members desired would have to be gained through the mobilization of their collective economic power, first at the bargaining table and second on the picket line. Through bargaining the USWA sought to change the traditional welfare capitalist model of employer provided insurance, which was undemocratic, temporary, and was used by employers as a device to control and pacify workers. Instead, the USWA wanted a comprehensive pension and social insurance program that was long-term, non-contributory (paid for entirely by the employer), and provided a democratic union voice over the administration of the plan. Although the union would be victorious in its campaign to bargain for security, the potential for a strike and the need for NLRB protection forced the union to reconsider its fight against the Taft-Hartley Act. Ultimately, this contest influenced Murray's decision to comply with the anti-labor law and sign the non-communist affidavits in July 1949 so that the union could receive NLRB protection throughout its bid for security. ${ }^{7}$

\section{Truman's Fair Deal and Inability to Expand Public Welfare}

The combined catastrophes of the Great Depression and World War II ignited a national thirst for the establishment of long-term welfare security. ${ }^{8}$ As mentioned earlier, the Depression witnessed the enactment of the Social Security system which established unemployment insurance, aid to families with dependent children, and the old age pension system. Indeed, compared with any other period in US history the 1930s marked a turning point in the role of the

\footnotetext{
Richard M. Fried, Nightmare in Red: The McCarthy Era in Perspective (New York: Oxford University Press, 1990); Robert Griffith, The Politics of Fear: Joseph R. McCarthy and the Senate. (Lexington: Published for the Organization of American Historians by University Press of Kentucky, 1970); John Earl Haynes, Red Scare or Red Menace?: American Communism and Anticommunism in the Cold War Era (Chicago: Ivan R. Dee, 1996); Ellen Schrecker, Many Are the Crimes: McCarthyism in America (Princeton: Princeton University Press, 1998); Stephen J. Whitfield, The Culture of the Cold War (Baltimore: Johns Hopkins University Press, 1991).

${ }^{7}$ See Robert H. Zieger, The CIO, 1935-1955 (Chapel Hill: University of North Carolina Press, 1995) 279-280 \& Chapter 9.

${ }^{8}$ See Klein, For All These Rights, 2003.
} 
federal government both in its relationship to the national economy and its relationship to individual citizens. Throughout the 1930s and into World War II many progressives desired to expand that relationship by strengthening various provisions of the Social Security system to include the enactment of a national healthcare system. Unfortunately, to the dismay of many progressives, the enervation of the New Deal's spirit of reform, the exigencies of WWII, and a growing conservative politics acted to stymie the enactment of national health insurance and the expansion of the overall Social Security Act. ${ }^{9}$ However, as WWII ended, progressive forces, including the USWA, believed that legislative reforms such as the Wagner Murray Dingell bill and the expansion of the Social Security Act might materialize under the Truman administration.

The death of FDR in the spring of 1945 thrust Vice President Harry S. Truman into the Presidency, leaving him with big shoes to fill. Historian Mary H. Blewett chronicled the early days of Truman's presidency. She observed that upon assuming the mantle of president, Truman desired to reinvigorate FDR's New Deal domestic reform agenda, albeit in his own unique way. Rather than engaging his political opponents in a more confrontational and militant style like his predecessor, Truman believed he could find domestic reform success with a less antagonistic approach. For instance, he felt that he could personally lobby congressional leaders to pass his agenda. He thus shied away from (1) developing concrete policy proposals; choosing instead to let Congress shape the agenda in the spirit of cooperation; and (2) he failed to sell his reform agenda to the American public. Truman's approach throughout 1945 proved problematic indeed as Blewett found that "bourbon and good fellowship failed to produce results." ${ }^{10}$ Truman's

\footnotetext{
${ }^{9}$ See Alan Brinkley, The End of Reform : New Deal Liberalism in Recession and War (New York: Alfred A. Knopf, 1995); Roger Biles, A New Deal for the American People (DeKalb: Northern Illinois University Press, 1991); Edward D. Berkowitz, America's Welfare State: From Roosevelt to Reagan (Baltimore: Johns Hopkins University Press, 1991) Chapters 3 \& 7.

${ }^{10}$ Mary H. Blewett, "Roosevelt, Truman, and the Attempt to Revive the New Deal" in Harry S. Truman and the Fair Deal ed. Alonzo L. Hamby (Lexington: D.C. Heath and Company, 1974) 86-87.
} 
legislative failures in 1945 and his inability to connect his vision with the broader public, combined with public anger over the 1946 strike wave, enabled conservatives to take control of the House and Senate in 1946, significantly diminishing the possibility of enacting more progressive legislation. ${ }^{11}$ Moreover, Truman's early performance created a rocky relationship between him and labor. Given these early setbacks, many Americans believed that Truman would lose the presidency in 1948.

Truman ultimately beat back pollster predictions and conventional wisdom to win the 1948 election, overcoming voter apathy and a divided Democratic party. Indeed, historian Irwin Ross found that "when the constituents of the popular vote are analyzed, however, it is apparent that Truman retained the basic elements of the old Roosevelt coalition." ${ }^{12}$ Upon winning the election, Truman saw an opportunity to offer the nation a more refined domestic reform agenda in the shape of his Fair Deal. The Fair Deal program focused on the following: (1) it sought to combat the growing menace of inflation; (2) it looked to institute "a more progressive tax structure;" (3) it advocated for the repeal of Taft-Hartley; (4) it called for increasing the minimum wage; (5) it advocated reform of the federal farm program and the expansion of public works; (7) it sought to reform national housing policy; (8) it called for the expansion of social security to include a national health care program; and (9) it sought to advance the cause of civil rights. ${ }^{13}$

Historian Alonzo Hamby argues that although Truman's Fair Deal had historical linkages to FDR's New Deal, the Fair Deal emerged within a new political and economic context.

\footnotetext{
${ }^{11}$ Nelson Lichtenstein, Labor's War at Home: The CIO in World War II (Philadelphia: Temple University Press, 2003), 230, 238-39.

${ }^{12}$ Irwin Ross, "What Happened in 1948" in Harry S. Truman and the Fair Deal ed. Alonzo L. Hamby (Lexington: D.C. Heath and Company, 1974) 108.

${ }^{13}$ Alonzo L. Hamby, "The Vital Center, The Fair Deal, and the Quest for a Liberal Political Economy" in Harry S. Truman and the Fair Deal ed. Alonzo L. Hamby (Lexington: D.C. Heath and Company, 1974) 139.
} 
Indeed, the New Deal was birthed from the ravages of economic depression and insecurity.

However, Truman's Fair Deal faced a new era of increasing prosperity and inflation. Moreover, Truman's failures in 1945 which facilitated an increase in conservative political power, combined with the exigencies of the Korean War and the intensification of anti-communism, all worked to limit significantly Fair Deal reforms. Hamby thus found that "Given the power of the well-entrenched conservative coalition and a wide-spread mood of public apathy about big new reforms, Truman could only enlarge upon the record of his predecessor." 14 Concerning the USWA's pursuit of long-term economic and health security, the various failures of the Truman administration, especially its inability to repeal Taft-Hartley as well as its failure to pass national health insurance, pushed the USWA to more fully consider private forms of welfare security achieved through collective bargaining. Despite his inability to pass much of his Fair Deal agenda, Truman would nonetheless prove influential in the USWA's bid to win economic and health security at the bargaining table in 1949 .

Forced retirements remained a significant issue to the USWA well into the postwar era. From April 1948 to the fall of 1948 Philip Murray had met a series of times with John Stephens of US Steel to resolve force-retirement grievances before they went to arbitration. In essence, both sides feared the unknown of arbitration. For Murray, arbiters might rule against the union more fully solidifying management's right to hire and fire employees, ultimately, taking issues of employment out of the realm of collective bargaining. Likewise, US Steel feared the diminishment of their managerial rights if arbiters found in favor of the union. ${ }^{15}$

\footnotetext{
${ }^{14}$ Ibid, 155.

${ }^{15}$ IEB, October 12, 1948, Box 43, Folder 14, 54-55; Historian Howell J. Harris documents the concerted effort on the part of capitalists to maintain their managerial and property rights as the nation returned to a peacetime footing after the end of World War II, Harris, The Right to Manage.
} 
In their last meeting, Stephens offered Murray a deal. He suggested that if the union pulled the grievances, the company would voluntarily stop the practice of force retiring older workers. Murray pondered Stephen's offer and countered it with a proposal to pull the grievances if the company would agree to rehire with back pay forced retired steelworkers who wanted to return to work. Stephens rejected the offer telling Murray that US Steel might consider rehiring discharged workers on a case by case basis and that although US Steel might voluntarily end forced retirements the company would retain the right to reinstate the practice. Murray subsequently informed Stephens that the union could not accept his proposal and would take its chances with arbitration. ${ }^{16}$

Although Murray rejected Stephens's offer, he nevertheless brought the offer before the IEB for a vote. In describing his encounter with Stephens, Murray informed the board that in conjunction with discussions over forced retirements he had also been pushing Stephens on the issue of pensions for force-retired workers, which the company dismissed outright. According to Murray, US Steel was of the opinion that most force-retired steelworkers had accepted their fate. US Steel cited the number of actual grievances filed, which was 78 . They argued that 78 grievances represent a small minority considering that US Steel and its various subsidiaries discharged roughly 250 steelworkers each month, and thus took the low amount of grievances as proof that most retires were content with the company's actions. ${ }^{17}$

It is unclear as to why there were so few grievances filed. One might speculate that some older steelworkers did accept the company's decision and attempted to cope with their retirement on an individual basis like countless steelworkers had done before them. Others might have believed that future rulings on the grievances already filed would eventually impact all retirees

\footnotetext{
${ }^{16}$ Ibid, $55-56$.

${ }^{17}$ Ibid, 59-61.
} 
and thus neglected to file their own grievances. Moreover, some retires might have put their fate in the union's 1949 bid to bargain for pensions and social insurance. Despite the number of grievances, the fact remained that the company looked to enforce and retain its right to manage, thus excluding policies of workforce management from collective bargaining. Also, thousands of retirees were struggling to make ends meet, and thousands of older workers not yet 65 lived in fear that they would also be forced to retire with little retirement security. In his closing remarks to the IEB, Murray recommended that the IEB reject Stephens's offer. He argued that the immediate benefits of the offer did not outweigh the long-term consequences of capitulating on the managerial rights question. Outside of an acceptable resolution between the USWA and US Steel, Murray suggested that it would be best to roll the dice with arbitration, thus declaring:

It may be that the position taken by the organization will result in wholesale discharges of innumerable men who have reached age 65, who have not as yet been discharged. But that is a risk and that is the hazard that one must assume if they are contending that under the contract the company has no right to discharge men who reach the age of $65 .{ }^{18}$

The executive board agreed with Murray and voted unanimously to decline Stephens's offer. ${ }^{19}$ Ultimately, the discharge cases never went before an arbiter. Instead, as we will see, the resolution of the issue came in the union's 1949 bid to bargain for pensions and social insurance.

\section{“People Like Machines Wear Out!": The USWA's Fight for Security in 1949}

Before the start of collective bargaining in June 1949, the union crafted a public relations campaign that attempted to highlight how the steel industry neglected the security needs of its workforce. The May 1949 edition of Steelabor depicted a steelworker who looked worn out and distraught, thinking about all of the downsides of being an industrial worker, including injury, insecurity in retirement, and unemployment. The headline emblazoned over this worker in

\footnotetext{
18 Ibid, 63.

19 Ibid, 65.
} 
despair read "People--Like Machines--Wear Out!" The USWA argued that workers needed employer-provided security and stability because industrial employment was unpredictable, dangerous, and finite. The slogan, "People Like Machines Wear Out," spoke to the lack of empathy on the part of industrial employers who coldly worried more about the upkeep of machinery than the people who operated those machines. ${ }^{20}$ Thus, the union, in an attempt to win the public relations battle and secure the moral high ground in the upcoming 1949 negotiations, stressed the fact that employers invested more in their capital stock than in their employees.

Many USWA members did not make enough money annually to cover things such as unexpected illnesses. According to USWA research, a typical steelworker with a family was estimated to need at least $\$ 5000$ a year to meet his financial needs including medical expenses; however, most steelworkers in 1949 fell short of that threshold. The USWA also argued that roughly 50 percent of the population had either no savings to draw from or, at a minimum, had "liquid assets" of only $\$ 500$. It was due to low wages and lack of benefits that many steelworkers often neglected to seek treatment when they became sick, making them increasingly prone to catastrophic illness and loss of work. ${ }^{21}$

The USWA also argued that low wages were detrimental to the lives of steelworkers, especially without adequate long-term pensions and social insurance. Hence, the June edition of Steelabor noted,

If an industry failed to pay enough wages to keep its workers from starving to death, the entire nation would be aroused. However, death by starvation is not the only consequence of low income. Many people die just as surely from haphazard, inadequate medical attention because they feel unable to afford the medical and hospital

\footnotetext{
20 “People Like Machines Wear Out!," Steel Labor, May 1949, 1; the union also used press releases and prewritten radio announcements at the district level, see for example, "David McDonald to District Directors: Delay in radio platter...," August 23, 1949 Box 139, Folder News Releases in 1949 Wage Case; "Vincent Sweeny News Release about retiree Andrew Girasek," 1949 Box 139, Folder News Releases in 1949 Wage Case, United Steelworkers of America, Communications Department Records, Historical Collections and Labor Archives, Special Collections Library, Pennsylvania State University. (Hereafter CD, title, date, box and folder).

21 "People Like Machines Wear Out!," Steel Labor, June 1949, 5.
} 
bills. Basically, there is little difference between death by starvation and death from insufficient and inferior medical care. ${ }^{22}$

Ultimately, the "People Like Machines Wear Out" campaign proved to be a valuable slogan and rhetorical tactic that facilitated the union's fight for security in 1949. As seen in Murray's trip to Youngstown, Ohio in October 1949 "throngs" of steelworkers showed up to hear him speak about the union's ongoing fight to bargain for long term welfare security, many of them brandishing signs "People Like Machines Wear Out" and other campaign slogans. The slogan not only resonated with USWA members, but more importantly it resonated with the presidential fact-finding board set up to mediate the eventual impasse over the issue of pensions and social insurance that developed between the USWA and the steel industry in the summer of $1949 .{ }^{23}$

With the public relations campaign established, the USWA in June of 1949 began negotiations with the steel industry. The union was attempting to win a wage increase and a comprehensive package of pensions and social insurance for their members. However, as bargaining got underway in June, it quickly became apparent to the union that the steel industry was taking an intransigent position on most issues. US Steel, its subsidiary companies, and other steel producers who had long followed the lead of US Steel in contract negotiations, systematically denied all union demands except for a few instances where the companies made inadequate offers on social insurance. The steel firms were adamant in their denial of a wage

\footnotetext{
22 "People-Like Machines-Wear Out!," Steel Labor, June 1949, 5.

23 "25,000 Hear Murray at Youngstown" Steelabor, November 1949, 3; "Murray Says Men Back Union, Police Estimate 20,000 at Park, C.I.O. President Opens Series of Talks Here; Denies Need to Stir Up Enthusiasm" Youngstown Vindicator, October 11, 1949, 34; "Murray Here for First Speech; U.S. Steel Calls New Steel Parleys...Throngs at Park" Youngstown Vindicator, October 11, 1949, 1; The Vindicator's coverage of the event highlights strong enthusiasm for Murray's visit and the issue of pensions and social insurance. Indeed, steelworkers began arriving to Wick Park well in advance of Murray, and steelworkers from small steel fabricators not yet on strike were so enthusiastic to attend the rally that most of the small steel fabricators shut down part of the afternoon to allow workers to attend.
} 
increase, and they argued that they were not required to bargain for pension provisions basing their argument solely on the language of the 1948 contract, which stipulated both sides could bargain only over wages.

Thus, the question became how does one define wages? The USWA was not the first to deal with this issue. The Allied Chemical Company also fought this issue in the courts. That case established the precedent that pensions were "deferred wages," and therefore subject to collective bargaining. It was followed by the Inland Steel case where the Seventh Circuit Court of Appeals ruled that pensions are subject to collective bargaining as deferred wages. When the United States Supreme Court refused to hear the Inland Steel Company's appeal, the Seventh Circuit Court decision became law. Thus, pensions were, in the eyes of the law, wages, or more specifically deferred wages and therefore negotiable under the contract reopening clause of the 1948 contract. $^{24}$

The initial round of collective bargaining between the steel industry and the USWA lasted roughly three weeks and came to a halt on July 7, 1949. ${ }^{25}$ At that point, Federal Mediation services under the leadership of Cyrus Ching intervened in the dispute. On July 11, 1949, USWA leadership and the leaders of the major steel companies met with Ching at the Department of Labor. Ching attempted to reconcile the demands of both parties; however, he came to the unfortunate conclusion that the steel industry was not going to budge on the USWA's demands and that further negotiations were futile. For USWA leaders it looked as if a strike was inevitable. David McDonald captured the frustration felt by USWA leaders over the steel industry's position. Speaking before the Wage Policy Committee (WPC) on the evolution of

\footnotetext{
24 “Court Rules Pensions Are Bargaining Subject," The Iron Age, September 30, 1948, 98; IEB, July 13, 1949, Box 43, Folder 16.

${ }^{25}$ United States, Report to the President of the United States on the Labor Dispute in the Basic Steel Industry (Washington: U.S. Govt. Print. Off, 1949), 16-17.
} 
contract negotiations McDonald stated, "We presented our facts. They didn't even argue back. They simply said, 'no', and now the conferences have terminated...."26 Ching reported the impasse to the President of the United States and recommended that he intervene with a factfinding commission to study the dispute. ${ }^{27}$ Subsequently, President Truman established a National Fact-Finding Board designed to review the issues associated with the 1949 steel negotiations with the intent of outlining a plan that would lead to a "...fair and equitable" settlement of the dispute. ${ }^{28}$

The President contacted both parties and requested a 60-day extension of the current contract and their participation in the fact-finding board. USWA President, Philip Murray agreed to the President's request on July 13; however, he held serious reservations as to whether the industry would comply. Rather, Murray believed that the steel industry was looking for a fight, telling the IEB that industry leaders were "hellbent, as I see it, on the ultimate destruction of the United Steelworkers of America." 29 Adding further that, "we have got to beat this gang, a band of professional pirates." 30 US Steel President Ben Fairless was immediately skeptical of the President's request. Steel industry leaders did not like the idea of a board that provided recommendations for further action. They pointed out that historically fact-finding boards established under the National Labor Relations Act never came with a mandate to provide recommendations. Although most of the steel industry was not happy with the idea of recommendations, they nonetheless agreed to comply with the President's proposal. ${ }^{31}$

\footnotetext{
${ }^{26}$ CD, "Mr. McDonald Speaks of the Termination of the Steel Negotiations," at WPC, July 12, 1949, Box 140, Folder Executive Board Wage Policy 1947-1949 2.

${ }^{27}$ United States, Report to the President of the United States on the Labor Dispute in the Basic Steel Industry, 17.

${ }^{28}$ Ibid.

${ }^{29}$ IEB, July 13, 1949, Box 43, Folder 16, 20.

30 Ibid, 21.

${ }^{31}$ United States, Report to the President of the United States on the Labor Dispute in the Basic Steel Industry, 1718.
} 
Due to the creation of the fact-finding board and the potential of a future strike, Philip Murray advised the July 13 IEB that it might also soon consider reevaluating the union's position on signing the non-communist affidavits. Given that the current showdown between the union and the steel industry revolved around the question of pensions as deferred wages, and given that the NLRB and the US Supreme Court had declared that pensions were indeed wages and thus bargainable, Murray believed it might be in the interest of the union to comply with Taft-Hartley by signing the non-communist affidavits in order to be eligible for NLRB protection. ${ }^{32}$ The union did not act on Murray's recommendation until its July 27 IEB where it prepared to vote on a resolution ordering union leaders to sign the non-communist affidavits.

The resolution spoke to the union's earlier opposition to the Taft-Hartley's noncommunist affidavits requirement. It stated that (1) the non-communist affidavits clause was "an unconstitutional invasion of the political freedom of unions" (2) the clause was "one-sided" in that it targeted labor only and did not have a reciprocal requirement denouncing all totalitarian ideologies to include "fascism" which industry leaders should be mandated to sign; (3) the provision along with the entirety of the Taft-Hartley law was anti-union; and (4) the affidavits had "no legitimate place in a labor-management relations act." 33 The resolution also argued that the USWA had been at the forefront of fighting Taft-Hartley and pushing for its repeal. Moreover, the union hoped that democratic victories in 1948 would have led to the repeal of the law, which had yet to materialize. Although non-compliance had not drastically weakened the union, continued defiance made the union increasingly vulnerable to jurisdictional conflicts with craft organizations such as the Machinists and the Electrical Workers as well as anti-union

\footnotetext{
${ }^{32}$ IEB, July 13, 1949, Box 43, Folder 16, 50-51.
}

${ }^{33}$ IEB, July 27, 1949, Box 43, Folder 17, 17-18. 
employers looking to reduce the influence of the union. ${ }^{34}$ Lastly, the resolution vowed that the union would continue its fight to repeal and/or weaken Taft-Hatley; however, it directed union leaders to sign the non-communist affidavits. ${ }^{35}$

Before voting on the resolution, Philip Murray offered some comments on the issue. He reiterated that the union had not been severely hurt since it decided not to sign the affidavits in 1947, but he did concede that the potential of organizations taking advantage of the union's unprotected position was likely. Beyond the fact that the union faced potential opposition in union elections, Murray also stated that due to non-compliance "our activities in the field of organizing are circumscribed." 36 Lastly Murray stated that "of more importance" was the need to have NLRB protection for the upcoming struggle with employers over pensions and social insurance. ${ }^{37}$

Beyond the potential organizational and material benefits to be gained from complying with the law, Murray, the most stalwart USWA advocate for not signing the affidavits, conceded to the board that his position had been a minority position amongst most of the union. Murray stated that for months he had been receiving an abundance of letters from individual members as well as local union resolutions asking him to comply with the law and sign the affidavits. ${ }^{38} \mathrm{He}$ ended his remarks to the board with a hint of humility declaring:

Many of you fellows are chirping back there today and you are smug and you are smiling because you have come around to me quite frequently and in the strictest of confidence of my office have said, 'Mr. Murray, I think you are making a mistake. You ought to qualify.' Well, far be it from me to disagree with that. I have been repeatedly compelled to say to you, 'Let's wait.' Well, we have waited and we know what has happened. It is

\footnotetext{
${ }^{34}$ Ibid, 19-20.

${ }^{35}$ Ibid, 20.

36 Ibid, 27.

${ }^{37}$ Ibid, 25.

38 Ibid, 30-31.
} 
not too late. We haven't suffered. We are qualifying at a time when the organization is not in jeopardy. ${ }^{39}$

Thus, with that statement of contrition, the resolution to sign the non-communist affidavits was brought to a vote and passed unanimously. ${ }^{40}$ With the union now legally protected by the law and the NLRB, the USWA set its eye on winning its case before President Truman's fact-finding commission.

The fact-finding board convened in mid-July and conducted hearings in New York City. It gave both sides ample opportunity to present their arguments, allocating eight days of testimony for the USWA and eight days for the steel industry. On July 28, 1949, the USWA presented its case before the board requesting a 30-cent per hour package to include 12.5 cents an hour for additional wages, 11.23 cents an hour to establish a pension plan, and 6.27 cents an hour for a social insurance plan. A vital component of the union's argument revolved around the "People Like Machines Wear Out" campaign. The union thus argued that employers have an economic and moral obligation to pay 100 percent of the long-term security needs of their employees in the same way that employers set aside funds for the maintenance and upkeep of their capital equipment. Once the USWA presented its demands, the board heard the industry's case.

The large steel producers remained adamant against increasing wages, and they continued to argue that pensions were not a negotiable item based on the language of the 1948 contract. ${ }^{41}$ The industry also focused heavily on the issue of inflation. Murray recounted to the IEB that all company officials, financiers, and corporately hired academics argued that the

\footnotetext{
${ }^{39}$ Ibid, 40 .

${ }^{40}$ Ibid, 57.

${ }^{41}$ United States, Report to the President of the United States on the Labor Dispute in the Basic Steel Industry,18-21.
} 
demands of the union would "ruin our free enterprise system." ${ }^{\text {"2 }}$ Ira Mosher (President of the National Association of Manufacturers) whom Murray referred to as part of "a band of sanctimonious racketeers" also spoke of the impending economic apocalypse if the board sided with the USWA. ${ }^{43}$ Murray recounted Mosher's testimony before the IEB noting that Mosher, "raised his saintly claws to the high heavens," and warned the board that the demands of the Steelworkers would ignite an inflationary calamity. This line of reasoning and argument infuriated Murray who understood inflation to be caused by the continuous price increases imposed by the steel industry throughout the postwar era. ${ }^{44}$ When describing to the IEB the testimony given by industrial leaders at the fact-finding board, Murray's animus toward these "sanctimonious racketeers" could not be held back. He viewed their testimony as hypocritical, and he loathed their interpretation of freedom based strictly on the market freedom of the individual, which ran counter to interpretations of freedom rooted in the collective group and social catholic thought. Thus Murray's social catholic sensibilities shined through when he declared to the IEB that, "when you sit in a courtroom and look at a great, big, fat, florid man, and hear him tell you that if you get pensions for the aged and hospitalization for the sick you are going to destroy individual freedom and free enterprise-Well, say, boys, if that's what is going to destroy free enterprise I am here to destroy it." ${ }^{\prime 4}$

\footnotetext{
${ }^{42}$ IEB, September 12, 1949, Box 43, Folder 18, 17.

${ }^{43}$ Ibid.

${ }^{44}$ Ibid, 14-17.

${ }^{45}$ Ibid, 69; for a more detailed look at the social catholic tradition and labor, work, and urban life see Kenneth J. Heineman, A Catholic New Deal: Religion and Reform in Depression Pittsburgh (Pennsylvania: Penn State University Press, 2005); Robert Bruno, Justified by Work: Identity and the Meaning of Faith in Chicago's WorkingClass Churches, (Columbus: Ohio State University Press, 2008); William Issel, Church and State in the City: Catholics and Politics in Twentieth-Century San Francisco (Philadelphia: Temple University Press, 2012); Saul Bronder, Social Justice and Church Authority: The Public Life of Archbishop Robert E .Lucey (Philadelphia: Temple University Press, 1982).
} 
On September 10, 1949, the fact-finding board issued its report. The board did not recommend a general wage increase; however, it did recommend that employers establish a noncontributory pension program at the cost of 6 cents an hour and a social insurance program at the cost of 4 cents per hour. The board also sided with the USWA's long-standing position that employers had a social and moral obligation to provide a social safety net for their employees since these provisions had yet to be established by the Federal government. ${ }^{46}$ The board's report concluded:

In our consideration of this program we have therefore placed much greater emphasis on the social considerations than on ability to pay. As hereinafter amplified, we think that all industry, in the absence of adequate Government programs, owes an obligation to workers to provide for maintenance of the human body in the form of medical and similar benefits and full depreciation in the form of old-age retirement-in the same way as it does now for plant and machinery. This obligation is one which should be fulfilled by enlightened business management not when everything else has been taken care of but as one of the fixed costs of doing business - one of the first charges on revenues before profits. It should be viewed as somewhat comparable to the necessity of making maintenance and depreciation allowances on nonhuman machinery. In this way practical effect will be given to the modern social consciousness on the subject of security for workers in industry. ${ }^{47}$

As is evident, the USWA's "People Like Machines Wear Out" argument influenced the board's ruling that steel companies had a moral and economic obligation to treat their human capital as well as they treated their physical capital.

After the board announced its ruling, the USWA Executive Board met to discuss the ruling and to vote on whether or not to accept it. Murray believed the board's ruling to be a supreme victory for the union even though the board failed to rule in favor of the union on a wage increase. He argued before the IEB that the "People Like Machines Wear Out" campaign was a success, declaring that the fact-finding board agreed that an industrial plant is not just,

\footnotetext{
${ }^{46}$ United States, Report to the President of the United States on the Labor Dispute in the Basic Steel Industry, 54 55.

${ }^{47}$ Ibid, 55.
} 
"made of metal or brick and mortar. They are also made of flesh and blood."48 Murray argued further that the ruling was beneficial to the old and the young alike, noting that "there isn't a man....in the room who does not have an aged relative, a father, perhaps a brother, an uncle or a cousin, or someone they know who is either living in their home or living close by" who is dependent on them. Ultimately, Murray believed that the ruling cleared a path to end the revolving door of dependency faced by older steelworkers and their families. ${ }^{49}$

Murray described to the board that other union leaders, in particular Walter Reuther of the UAW, found the board's ruling to be a monumental game changer. Murray noted that he had recently invited Reuther to stay with him for a few days at his home in Pittsburgh to discuss the issue of pensions and social insurance. Like the steelworkers, the auto workers were also seeking to bargain with Ford on the issue of pensions and social insurance. Humorously, Murray declared that Reuther "has almost slept with me since last Friday night. I could not get rid of him." 50 Beyond counseling and offering support to Reuther, Murray had the chance to show him a copy of the fact-finding board's ruling. According to Murray, Reuther, after reviewing the report declared "'I wish we could get this at Ford tomorrow."” Also, Reuther told Murray that he believed the board's ruling was "the greatest human document ever contrived in the mind of man, it was another Magna Charta, in the great big field of human welfare." ${ }^{51}$

Philip Murray understood to a degree the broader impact the ruling would have outside the narrow confines of the USWA. He suggested that the ruling, particularly the section declaring that the company had an obligation to pay the entire cost of the security program was

\footnotetext{
${ }^{48}$ IEB, September 12, 1949, Box 43, Folder 18, 21.

${ }^{49} \mathrm{Ibid}, 32-33$.

${ }^{50}$ Ibid, 68.

${ }^{51}$ Ibid, 68.
} 
"fundamental and will be so far reaching in its consequences." ${ }^{2}$ Moreover, Murray viewed the ruling as a key that opened up the possibility of using the union's economic power via collective bargaining and a potential strike as a means to win long-term economic and health security for the union as well as a large segment of the American citizenry. He thus declared:

My prime interest in this situation, therefore, is not the fact alone that we have won for ourselves a degree of recognition in the field of pensions and insurance - it is not that alone. It is the perpetuity of the plan, it is the perpetuity of the system, it is the institution and the effectiveness of the plan that will benefit more by the people in the United States of America than any other plan that has ever been declared for by any group at any time in the history of this nation of ours. ${ }^{53}$

Philip Murray was prescient in his judgment of the impact of the fact-finding board's ruling. In many respects, it opened the door for the postwar proliferation of private welfare plans and the full development of the nation's public-private welfare state. Indeed, the ruling fit with Murray's liberal progressive ideology that stood as a bulwark between what he viewed as leftist totalitarianism in the form of communism and the Soviet Union and rightist totalitarianism in the form of fascism. In his mind, America was the flawed but righteous fulcrum between two extremes. The board's ruling fit with Murray's economic philosophy and vision of American capitalism. "We want the free enterprise system to work for all Americans" Murray declared, “and we don't want 'naked exploitation' by big business, which if unchecked, surely breeds depression. ${ }^{" 54}$ In Murray's mind, private pensions and social insurance were tools and programs that made American capitalism palatable. He viewed them as complementary to Keynesian fiscal and monetary intervention, the postwar full employment legislation campaign, the guaranteed annual wage, and other progressive forms of government regulation. ${ }^{55}$

\footnotetext{
${ }^{52}$ Ibid, 22.

${ }^{53}$ Ibid, 25.

54 “"CIO Program is Insurance Against Bust”" Steelabor, February 1949, 4.

${ }^{55}$ For a detailed analysis of the CIO's postwar progressive political agenda see Robert H. Zieger, The CIO, 19351955 (Chapel Hill: The University of North Carolina Press, 1997) 312-328.
} 
Murray went on to define what he called the "human welfare state." He stated that "we regard the human-welfare state as America's middle way. It should be neither right [nor] left, but progressive, open-minded and daring." 56 The board's ruling brought Murray's vision closer to reality. Unfortunately, however, neither Murray nor anyone else from that era could have predicted with certainty what the future held for employer-based welfare security or the evolution of the public-private welfare state. Murray had no way to predict the future restructuring of the nation's economy, the rise of cheap transport and computer technology, nor could he predict the complete dismantling and degradation of an industry as significant and as globally dominant as the American steel industry. Murray at that time understood that capitalist economies fluctuate and often manifested terrible results such as depressions, recessions, and runaway inflation. However, for Murray, building a system of long-term welfare security on the back of corporate surpluses (profits) seemed to him a stable and secure strategy. The factfinding board thus gave its approval to that strategy, and despite the systemic problems that would eventually develop in the area of private welfare security in the last quarter of the twentieth century, the USWA took the ruling and set out to use its economic power at the bargaining table to contractually secure it.

\section{The 1949 Steel Strike}

In the wake of the fact-finding board's ruling, President Truman requested that the union and the steel industry agree to an eleven-day extension of the current contract and re-enter negotiations. The USWA, in a manner similar to previous presidential requests, agreed to Truman's proposal and began preparing for future negotiations and the possibility of a strike. ${ }^{57}$

\footnotetext{
${ }^{56}$ Ibid.

${ }^{57}$ IEB, September 12, 1949, Box 43, Folder18, 33-36, 53-55.
} 
Although quick to comply, Murray did not expect the industry to reciprocate, declaring before the IEB, “To be perfectly frank with you gentlemen, I know they don't like it. They have said that so often that I can hear the din of their thunderous voices in my ears now." $" 58$ The reason was simple. It was not that industry hated the concept of private security; instead, it was that industry loathed the idea of government intervention that sided with the union, notably a ruling that called for industry to pick up 100 percent of the social insurance tab. Moreover, the industry disliked the fact that the union also sought to interject a democratic voice into the administration and oversight of a pension and social insurance program. ${ }^{59}$ In essence, the fact-finding board's ruling and the possible expansion of democracy in the workplace threatened to weaken employers' right to manage and reduce the potency of control found in the steel industry's traditional welfare capitalist security plans, which many other corporations were unilaterally instituting in an attempt to win the loyalty of their workers. ${ }^{60}$ Rather than capitulation, Murray expected continued intransigence on behalf of the companies most likely leading to a strike.

David McDonald discussed this last point with the IEB. McDonald suggested that the union, with the help of the board's ruling, was looking to alter the traditional welfare capitalist dynamic with a system of permanent long-term security rather than traditional company-run security program that "are only temporary in their existence" and often only "exist...from contract to contract." ${ }^{\prime 1}$ McDonald also provided the board with his thoughts on the ruling and its potential geopolitical impact. He argued that the communists:

Have been saying to the people of the world, just give us a chance, we will give you economic security in exchange for your individual freedom. Well, Phil Murray has just murdered his arch foe, communism, because he has given the people economic security

\footnotetext{
${ }^{58}$ Ibid 35.

${ }^{59}$ Ibid.

${ }^{60}$ See Sanford M Jacoby, Modern Manors: Welfare Capitalism since the New Deal (Princeton: Princeton University Press, 1997).

61 Ibid, 44.
} 
and individual liberty, he has proven to the people of the world that this system of ours, this democratic system is a living, dynamic force and it can provide the best way of life for all mankind. ${ }^{62}$

For the most part, members of the IEB were in wholehearted agreement with the arguments made by Murray, McDonald, and other top-level leaders of the USWA. However, the record does reveal that some union members initially had reservations with the board's ruling; in particular, they worried about how a new social insurance plan built around the concept of noncontributory insurance would impact the company insurance plans they had been paying into. The only hint of this dissent in the IEB record came from local 1011 from USWA District 31. At the September 12 IEB, Board member Heath (first name not given) representing District 31 rose in opposition to a resolution supporting the fact-finding board's ruling. Heath stated that he was acting, "more or less as a spokesman for sub-district 2 in Dist 31," and that those he represented were opposed to the resolution for fear of the impact it would have on current company provided social insurance plans to which many union members had been contributing over the years. ${ }^{63}$

Murray immediately addressed Heath's concern. He argued that Heath and those he represented "misunderstood" the issue at hand, which according to Murray was the imperative of inculcating the concept of non-contributory insurance throughout the steel industry and eliminating the exploitative nature of traditional company insurance plans. He argued that "a contributory plan is a company union device, never written into a contract and never set forth and never specified in language sufficiently protective of the interests of the people who contribute toward the maintenance of the plan." Moreover, without such contractual certainty companies could change the plan if and when it suited their own specific needs. ${ }^{64}$ Murray went

\footnotetext{
${ }^{62}$ Ibid, 45.

${ }^{63}$ Ibid, 43.

${ }^{64}$ Ibid, 62.
} 
on to highlight the poor track record associated with welfare capitalist insurance plans. He reminded the IEB that US Steel contributed only "one-fifth of one cent per hour" toward its insurance plan while the remainder of the plan's cost fell on the shoulders of the worker. ${ }^{65}$ Moreover, Youngstown Sheet and Tube allocated one cent per hour for their pension plan as compared to the possibility of achieving a 6-cent per hour pension plan as specified by the factfinding board's ruling. ${ }^{66}$

The insufficient nature of steel industry insurance plans did not begin or end with US Steel or Youngstown Sheet and Tube; rather, after months of investigation by the USWA social insurance expert Murray Latimer, in conjunction with the USWA research department, found that there were over 300 weak and disparate welfare capitalist insurance plans across the industry. "I am free to admit" Murray announced, "That none of the 300 plans approximate that sum of money that is going to be expended under this plan... [T]hey are pitiful, but they are the best that our local unions have been able to extract out of these companies under the best circumstances." ${ }^{97}$ Murray also stated that welfare plans under the fact-finding board ruling do not preclude any individual USWA member from purchasing more insurance above and beyond the contract. ${ }^{68}$

In closing, Murray asked Heath if it was his local's intention to refuse to strike if continued bargaining resulted in an unreconcilable impasse. Heath replied, "No sir," indicating that local 1011 was on board with a potential strike. Murray suggested that Heath continue to think about the bigger picture of what the union was trying to accomplish with its emphasis on

\footnotetext{
${ }^{65}$ Ibid, 62-63.

${ }^{66}$ Ibid, 67.

${ }^{67}$ Ibid.

${ }^{68}$ Ibid 49; IEB September 22, 1949, Box43, Folder 20, 31-32.
} 
instituting non-contributory pensions and social insurance plans that were significantly better than the current welfare capitalist plans in operation throughout the industry ${ }^{69}$

After the presidential fact-finding board published its report a series of telegraph exchanges took place between Philip Murray and Benjamin Fairless. The USWA's primary point of contention was that US Steel would not commit to the fact-finding committee's recommendations, especially its recommendation that the company pay for the entire cost of a social insurance program. The company maintained that the fact-finding board was not established to have binding authority over bargaining between USWA and US Steel. In response to US Steel's intransigence, Murray telegraphed Benjamin Fairless and informed him that US Steel's position was basically saying "The public be damned." ${ }^{70}$ Murray further protested US Steel's implacable position as well as the inherent unfairness in the existence of long-standing non-contributory pensions for steel executives while the company resisted the same type of security for its workers. Murray thus declared:

You assert that this is a matter of fundamental principle, notwithstanding that you, Mr. Fairless, and other executives in your Corporation and in the industry will enjoy substantial pensions upon retirement, based upon non-contributory programs created by the industry for the benefit of its executives rather than its workers. The Union and the public will not, do not, accept any such unfair tactics on your part. ${ }^{71}$

To break the impasse, Cyrus Ching of the Federal Mediation service requested the attendance of the leading steel producers and USWA leaders to a mediation conference held in Washington D.C. on September 19, 1949. At the conference, Philip Murray stated that the USWA wanted to negotiate but would not abandon the findings of the fact-finding board noting, "It must be obvious to all that the only way a prompt settlement can be concluded, and a strike

\footnotetext{
${ }^{69}$ IEB September 12, 1949, Box43, Folder 18, 64-65.

${ }^{70} \mathrm{CD}$, “Mr. McDonald Reports on the Latest Developments in the Steel Case" at WPC, September 22, 1949, Box 140, Folder Executive Board Wage Policy 1947-1949, 3.

${ }^{71}$ Ibid.
} 
averted is on the basis of the board's recommendations."72 Murray drew the proverbial line in the sand by placing the findings of the board between the USWA and US Steel; however, US Steel maintained its defiant stance. The union believed it held the moral high ground and was not going to back down on the issue.

On September 21, 1949, both groups met again for negotiations in Washington D.C. However, this time a letter from President Truman addressed both parties and reiterated that he was in support of the fact-finding board's recommendations and he urged both parties to accept them to avert a steel strike that could have harsh economic consequences on the nation. ${ }^{73}$ The president also - understanding that both sides were at an impasse - requested the strike deadline be extended to October 1, 1949, with the hope that a contract could be hashed out and a national steel strike averted. Both sides agreed to an October 1 extension.

As the strike deadline approached, it was clear to government mediators that both sides would not be able to reach a deal. Government conciliator William N. Margolis described the bunker mentality exhibited by both parties. He stated in a New York Times interview that he and his fellow conciliators "had never encountered a situation in which the parties were 'so adamant and yet so affable."'74 Although a strike looked inevitable the New York Times reported that just before the deadline "government mediators explored a number of 'face-saving' compromises" to no avail. ${ }^{75}$ At 12:01 a.m. on October 1, 1949 negotiations came to a formal end and the 1949 steel strike had begun. Although the majority of the union started the strike at the designated time, some eager unionists from disparate locals across the nation initiated the strike before the

\footnotetext{
${ }^{72}$ CD, “"Mr. McDonald Reports on the Latest Developments in the Steel Case" at WPC, September 22, 1949, Box 140, Folder Executive Board Wage Policy 1947-1949, 5-6.

${ }^{73}$ CD, "'Mr. McDonald Reports on the Latest Developments in the Steel Case" at WPC, September 22, 1949, Box 140, Folder Executive Board Wage Policy 1947-1949, 8.

74 "Parleys Collapse" by A.H. Raskin, New York Times, October 1, 1949, 3.

${ }^{75}$ Ibid.
} 
formal deadline. Ultimately, the strike brought the majority of the nation's steel production to a halt, minus some small steel producers and fabricators as well as non-USWA firms such as Weirton Steel. Moreover, the strike involved close to 500,000 steelworkers in basic steel who were determined to win long-term economic and welfare security. ${ }^{76}$

As we have seen in the introduction of this chapter, the USWA rank-and-file fell in line with the union's strategy, and gave their all, in support of the fight for pensions and social insurance. This issue touched the old and young alike as both groups had something significant to gain from a victory. Older workers already force-retired or facing force-retirement understood that the union's fight for security might transform the lives of many retirees currently living off little to no company pensions and a paltry social security payment that when combined often left retirees destitute. Indeed, some retirees had formed formal "65-Clubs" to raise awareness of the plight of retirees and offered their support to the union's bid for pensions and social insurance in $1949 .{ }^{77}$ On the other side of the coin, younger workers too understood that the fight in 1949 would prevent the threat of force-retirement in the future, and more immediately would provide them and their families with coverage against poor health, sickness, and injury. Indeed, Murray's speaking tour of basic steel showcased the solidarity and support given by rank-andfile steelworkers in the cause of security.

Workers at smaller steel producers and fabricators, most of whom settled the strike weeks after the eventual victory in basic steel, were just as enthusiastic and supportive of the strike. Local 3317, District 9, of the small steel concern called New Jersey Zinc in Palmerton, PA, highlighted a quintessential example of the resolve of rank-and-file employees from smaller steel concerns during the 1949 strike. Local 3317 went on strike a few days before the basic steel

\footnotetext{
${ }^{76}$ Ibid, 1,3 .

${ }^{77}$ See for instance ““65-Club’ formed by USA Members,” Steelabor, November 1949, 9.
} 
strike date of October 1. Indeed, from September 26 through February 1950, local 3317 members maintained a 24-hour picket line presence and showed no signs of wavering. Their determination to resist and to maintain their fight for pensions and social insurance is just one of a series of outward displays of solidarity and unity during the strike. When asked to describe the strike and the attitude of workers, District 9 director C.B. Newell told reporters that, "I have never in my life witnessed such a unanimous display of spirit as these union people at Palmerton are displaying." He added, "with every passing day they become more and more determined to stay in the fight until New Jersey Zinc Co., recognizes its obligations." ${ }^{78}$ For rank-and-filers such as Izedor Mihalik, a 25-year veteran of local 3317, the importance of his union securing a pension and social insurance could not be overstated. His resolve to persist in the face of incredible company intransigence can be witnessed in his action as picketer. From September 26, 1949 until February 1950, Mihalik missed only three days on the picket line. ${ }^{79}$

The fighting spirit was not just the purview of the individual steelworker; instead, the fight for pensions and social insurance was also a community affair. One salient example of the community spirit during the strike came as the stoppage persisted into the Christmas season. With family budgets dwindling or non-existent, the strike severely limited the ability of strikers to purchase Christmas gifts for their children. Rather than do without, the union and the broader community held a Christmas party for union members and their families. At the party, Santa Clause was present, and distributed presents to the over 2000 children of local 3317 members. ${ }^{80}$ By mid-October, it looked as if neither side would give ground, especially US Steel, the bellwether company that traditionally set the pattern which all other steel companies followed.

\footnotetext{
78 "New Jersey Zinc Local Fighting for Pensions and Social Insurance" Steelabor, February 1950, 5.

${ }^{79}$ Ibid.

${ }^{80} \mathrm{Ibid}$.
} 
However, in a surprising turn of events, the Bethlehem Steel Company broke ranks with US Steel and became increasingly open to finding a compromise with the USWA. Bethlehem officials met with Philip Murray and Arthur Goldberg in New York throughout the last week of October. At the meeting, Murray deviated from his earlier demands that looked to secure the entirety of the fact-finding board's ruling. He suggested the company agree to a 12 cent an hour pension and social insurance package made up of a 9-cent an hour non-contributory pension and a 3-cent an hour contributory social insurance program. Bethlehem said they would consider the offer and discuss it the following day. ${ }^{81}$

At the next meeting, company officials informed Murray that they did not like the concept of building the pension plan on a cent per hour basis. Instead, they argued that the union consider Bethlehem's current pension program but with modifications. Bethlehem Steel had recently modified its traditional welfare capitalist pension plan in 1948. The plan was an upgrade from past plans, and it provided $\$ 50$ a month for workers 65 or older who had at least 25 years of service. On top of the $\$ 50$ a month pension, workers also kept and retained their social security payment. ${ }^{82}$ Murray was amenable to the proposal as long as the company increased the pension payment to $\$ 100$ a month, and also expanded the pension program to incorporate pensions at a decreased rate for workers who had at least 15 years of service to the company. Murray also argued for the implementation of disability pensions of at least $\$ 50$ a month. ${ }^{83}$ After Bethlehem and USWA negotiators came to a tentative agreement on pensions, they next turned their attention to social insurance. Here too, both sides were open to compromise. In terms of social insurance, Bethlehem was more open to accepting a plan based initially on a cent

\footnotetext{
${ }^{81}$ IEB, November 2, 1949, Box 43 Folder 21, 11-13.

${ }^{82}$ Ibid, 14.

${ }^{83}$ Ibid, 15-19.
} 
per hour basis, with the understanding that future negotiation would be conducted to figure out how the monies collected would be spent on insurance. The tentative deal encompassed a 5-cent per hour plan on a contributory basis; the workers would pay $2 \frac{1 / 2}{2}$ cents per hour, and the company would pay $2 \frac{1}{2}$ cents per hour per worker. Negotiators also agreed that the new social insurance plan would cover life and sickness insurance, as well as hospitalization via a national Blue Cross plan. ${ }^{84}$ Murray believed that the hospitalization plan was exceptionally noteworthy, informing the IEB that it was "the first time in the history of the nation a large company of this kind has accepted the Blue Cross as the sort of an institution that should be contracted with for these benefits." ${ }^{" 15}$

On November 1, 1949, Bethlehem Steelworkers were greeted with the news that union negotiators had struck a deal on pensions and social insurance with Bethlehem steel bringing an end to the month-long strike. As the ink dried on the contract, steelworkers learned more about the entirety of the benefits gained. The formal agreement created a 100-dollar a month noncontributory pension for workers age 65 or older with at least 25 years of service. Workers aged 65 with less than 25 years of service but at least 15 years of service were now eligible for a prorated pension based on years of service from 15 to 24 . Disabled workers were eligible for a 50dollar a month disability pension. ${ }^{86}$ Moreover, according to New York Times reporter Louis Stark, pre-1949 retirees who currently "get an average of $\$ 12$ weekly under the present plan, will receive pensions of $\$ 100$ monthly." ${ }^{87}$ Total pension payments under the 1949 deal included a worker's social security payment, which impacted the company's total pension obligation. ${ }^{88}$ For

\footnotetext{
${ }^{84} \mathrm{Ibid}, 23-25$.

${ }^{85}$ Ibid, 25.

86 "Bethlehem Signs With Union for Pensions, Welfare Plan; U.S. Steel Seeks New Talks" by Louis Stark, New York Times, November 1, 1949, 1,3.

${ }^{87}$ Ibid.

${ }^{88}$ Ibid.
} 
instance, a portion of a retiree's $\$ 100$ a month pension also included a steelworker's social security payment, which offset the company's outlay. In essence, the inclusion of social security meant that the company did not have to pay the full $\$ 100$, making the potential expansion of the Social Security system financially beneficial for steel producers under the terms of the 1949 contract.

With regard to social insurance, the final deal established an equally split contributory insurance plan based on a total rate of 5 cents an hour $\left(2 \frac{1}{2}\right.$ cent worker contribution and $2 \frac{1}{2}$ cent company contribution). The social insurance plan established national Blue Cross hospitalization coverage for the steelworkers and dependents. It also established a $\$ 3,000$ life insurance policy convertible upon retirement to a paid-in-full policy amounting to $\$ 1,250$ to $\$ 1,500$. Lastly, the social insurance plan included a provision for sick benefits of $\$ 26$ a week for 26 weeks. ${ }^{89}$ Both the pension and social insurance funds were scheduled to take effect within the first few months of 1950. Moreover, the union retained its right to strike if the company attempted to terminate the plan. Although the union compromised by agreeing to a contributory social insurance plan, the USWA was successful in its effort to win a non-contributory pension plan and possibly more important, the union was successful in its bid to institute a democratic voice over the administration of the plan ending the arbitral nature of pension programs under traditional welfare capitalist schemes. ${ }^{90}$ The final contract thus established a "joint pension committee of ten, divided equally between the union and management."91

\footnotetext{
${ }^{89}$ Ibid.

${ }^{90}$ Alan Derickson also writes that achieving a voice over the administration of private welfare was a serious goal of the USWA, see Alan Derickson, "The United Steelworkers of America and Health Insurance, 1937-1962" in Sally M. Miller and Daniel A. Cornford ed., American Labor in the Era of World War II (West Port: Praeger, 1995) 7479.

${ }^{91}$ Ibid.
} 
When asked to comment on the strike and what that meant for those still striking, Murray told reporters that he believed the deal would become the basis for settling remaining disputes, notably the ongoing strike at US Steel. ${ }^{92}$ Indeed, Murray's prediction soon materialized. From November 1 to November 10, 1949, much of basic steel agreed to contracts mirroring the Bethlehem contract, and by November 10, 40 percent of the steel industry was back in production. The last major holdout, US Steel, was now finding it difficult to retain its uncompromising stance. On November $10^{\text {th }}$ and into November $11^{\text {th }}$, US Steel finally capitulated, agreeing to the Bethlehem contract, thus ending the 1949 strike in basic steel. ${ }^{93}$

\section{Conclusion}

Philip Murray addressed leaders of the union at a post-contract-signing meeting held at the William Penn Hotel in Pittsburgh. With a "rising tide lifts all boats" mentality, Murray stated:

This agreement won in the steel industry is one of the most important our union has ever won and it represents one of the most far-reaching gains ever made for the people of America. Of course it means a tremendous stride forward in the protection of the aged, the sick and the injured who are dependent on the steel industry. But it is impossible to estimate how much this victory will also mean for millions of other people who will eventually feel the effect and reap the benefit of our victory. ${ }^{94}$

One can only imagine the sense of relief and happiness that most steelworkers must have felt after the 1949 strike victory. After years of struggle to form a union and to make ends meet during the Great Depression and World War II, the promise of a secure and stable future was at hand. Oddly, steelworkers had finally achieved equivalency with machines in terms of company

\footnotetext{
92 Ibid.

93 "Pension, Social Insurance Now Part of the USA Contracts," Steel Labor, December 1949, 2; "US Steel Parley Set Today; Youngstown Tube Signs Pact” by A.H. Raskin New York Times, November 10, 1949, 1,10; IEB November 18, 1949, Box 44 Folder 1, 6-8.

94 “Pension, Social Insurance Now Part of the USA Contracts," Steel Labor, December 1949, 2.
} 
investment, maintenance, and care. ${ }^{95}$ Moreover, the 1949 victory made an immediate and tangible impact on the lives of steelworkers, especially those nearing retirement. Take, for instance, A.M. Byers Company employee Louis Miller, who at his retirement in July 1950, had been with the company for 59 years. However, now because of the 1949 contract, Mr. Miller was eligible to retire on a combined pension and social security payment amounting to $\$ 174 \mathrm{a}$ month, a gigantic step forward from the pittance of $\$ 8.80$ a month that many retirees received before the contract. ${ }^{96}$

For the most part, the union had achieved what it set out to do. Since 1946 when the steel industry had begun the practice of arbitrarily retiring workers who reached age 65 , the union had been wrestling with how best to deliver the long-term economic and health security to its members. As we have seen the union's effort to enact a national healthcare program fell short in the immediate postwar period. Moreover, the loss of political power in 1946 led to the enactment of the anti-labor Taft-Hartley bill. The union's efforts to repeal the law and fight its constitutionality in the courts placed the union in a vulnerable position vis-à-vis rival unions and combatant employers. USWA leaders, navigating the tumultuous arena of postwar politics and responding to the demands of their rank-file-members, set out in 1949 to use their economic power at the bargaining table to force the steel industry to provide for the long-term care, upkeep, and security of their workers. In doing so, the union emphasized that any program of employer-provided long-term welfare security needed to go beyond the weak, arbitrary, and temporary welfare capitalist schemes of the past, and instead, provide comprehensive benefits that were fully paid for by the company and that allowed for a democratic voice over the administration of the plan.

95 “People-like Machines-Now Will Be Given Care!” Steelabor, December 1949, 3.

96 “And Now for a Good, Long Rest," Steelabor, July 19505. 
Ultimately, the USWA's effort to bargain for security in 1949 was met with strong industry resistance that led to presidential intervention and then a month-long national steel strike. In the end, the union secured what it believed to be a substantial package of benefits that, absent a non-contributory social insurance plan, exceeded the national fact-finding board's recommendations. The fight for pensions and social insurance in 1949 was indeed a great victory for steelworkers across the country, and the victory would reverberate for many years, as unions facing similar membership demands for security would seek long-term welfare benefits at the bargaining table. Although 1949 ushered in a new era in employer-provided benefits, throughout the 1950s the union continuously worked to expand and improve the program. However, by the end of the decade, the USWA would come to realize the problematic nature of building a security program on the indemnity insurance model. 


\section{Chapter 6: The USWA Pension and Social Insurance Program from 1949 to 1960. Introduction: John Greer and the Benefits of Industrial Unionism}

The USWA's 1949 pension and social insurance victory was indeed a blessing for many Steelworkers, especially for older steelworkers such as John Greer, a 52-year veteran of Bethlehem Steel's Sparrows Point mill in Maryland. Due to the 1949 victory, Greer was now able to retire with dignity and increased long-term financial security. The enormity of the victory was not lost on Greer, in fact, in his retirement Greer became a spokesman for the union, extolling the benefits of unionism to the younger generation of steelworkers. Imbedded in Greer's story is an example of both the enormous economic advances the USWA and its membership made from the pre-union era up to the mid-1950s as well as the internecine divisions within the union that would develop over the course of the second half of the twentieth century.

In an interview given to Steelabor in late 1956, Greer described his life in the mills prior to the union. He began working in 1905 and received a wage of $61 / 2$ cents an hour $(\$ 1.66$ an hour in 2018). Moreover, prior to the union, Greer and his fellow workers lacked long-term security in the form of pensions and social insurance and lived under the social and economic domination of their employer. He recalled that "if you were married and were trying to raise a family, the best you could do was bite your lip and hope that you wouldn't live too long after you could work no more." ${ }^{1}$ Greer also spoke to the vagaries of employment due to the business cycle. Work in the pre-union era was often sporadic; however, workers lacked access to support structures such as unemployment insurance or supplemental unemployment benefits, which the USWA won in 1956. Greer remembered that the ups and downs of employment in the pre-union

\footnotetext{
1 “Ask The Man Who Knows” Steelabor, December 1956, 12.
} 
era "kept a man constantly in hock and oftentimes the food on the table was barely enough to keep a family alive." ${ }^{2}$ In essence, Greer and countless other industrial workers lived in a society that espoused the virtues of freedom and democracy for its citizens yet often deprived them of freedom and democracy in their economic lives. Without a union to offer workers a voice over hours, wages, benefits, and working conditions, workers of Greer's generation lived a life of dependency rather than independence, ever fearful of stepping out of line and losing their job.

Beyond the day-to-day employer domination inside the mill, Greer also recounted the desperate conditions faced by retirement age workers in the pre-union era. Rather than being the grand reward of a life filled by hard work and devotion to one's employer, the idea of retirement was a foreboding nightmare looming on the horizon for those nearing retirement age. According to Greer, when retirement came, whether voluntary or involuntary, a steelworker lost any semblance of independence. Without strong pensions and access to Social Security, workers in the pre-union era frequently lacked the means to support themselves in retirement and often had to rely on their children or extended family to make ends meet. As Greer saw it, once retired in the pre-union era, 'a man couldn't afford to live long. 'Retirement' was only another word for slow starvation."3

It was from these pre-union conditions that Greer and thousands of other steelworkers of his generation came to intensely understand the social and economic value of a strong union, which worked to eradicate, through collective bargaining and political action, the desperate conditions faced by steelworkers in the days prior to the USWA. Indeed, Greer declared, "until the union came along, I figured I was just working myself into the grave-maybe a pauper's

\footnotetext{
2 Ibid.
}

3 Ibid. 
grave at that. If you so much as looked cockeyed at the boss, you not only found yourself out of a job but you found your family was out in the street."

Although the pre-union era conditions described by Greer did not end overnight once the union was born, from 1936 to 1956 the USWA worked tirelessly to end employer domination and worker dependency, thus helping to give workers more democracy, independence, and economic security in their lives. Indeed, from 1936 to 1956 the USWA had won unprecedented economic and welfare security gains for its members through collective bargaining. The list is extraordinary, especially in light of the work conditions, pay scales, and lack of benefits countless workers face today. For instance, by 1956 rank-and-file steelworkers had access to Sunday premium pay, supplemental unemployment benefits, pensions, social insurance, paid holidays, holiday premium pay, paid vacations, shift premiums for afternoon and midnight turns, severance pay, incentive earnings protections, seniority, a grievance system, better workplace safety conditions, and cost of living increases. The majority of these benefits were non-existent in the pre-union era or were weak and part of undemocratic employer-dominated welfare capitalist programs. ${ }^{5}$ Given the mass improvements in the standard of living for rank-and-file steelworkers in the union's first twenty years of existence, it is not hard to understand why Greer and many like him were not shy to state that being a union member was the "greatest investment I ever made.” Noting further that “...every nickel of dues I paid has been returned to me a hundred-fold. I only wish the union had won its fight sooner-so I could have looked forward to that many more years to the future-instead of fearing it."

\footnotetext{
4 Ibid.

5 "Here's What That Card Means to You! The Best Insurance Policy in the World" Steelabor, November $1956,3$.

6 “Ask The Man Who Knows" Steelabor, December 1956, 1.
} 
With the rise of the USWA, John Greer's life got better with each bargaining and/or political victory. Not only did his life improve, but the increased standard of living wrought by the union from 1936 to 1956 enabled Greer to vastly improve the lives of his 5 children, ensuring that they would not face the same hardships that Greer and his generation faced as they entered adulthood. Greer's mention of his children also offers an example of a new postwar phenomenon that the union and its members would grapple with in the years to come. Due in great part to the many bargaining victories of the industrial union movement, as well as the rise of New Deal liberalism, the U.S. victory in World War II, the expanded postwar middle-class and the rise of postwar consumerism, a new generation of Americans were coming of age absent a lived connection to the myriad struggles and hardships faced by union pioneers such as John Greer. ${ }^{7}$ For instance, by 1956 the union was beginning to see segments of the rank-and-file pose challenges to the entrenched USWA leadership and vigorously protest dues increases, something that seemed unfathomable to Greer. ${ }^{8}$

The experiential disconnect between new workers and older workers was one of the reasons the union asked Greer to speak to the younger generation about life prior to the union. Greer told Steelabor that "anybody who grumbles about paying dues in return for an investment like that is either blind to the facts of life or just plain crazy." Noting further that, "these young fellows have something already built for them. Unity is the only thing that will keep it together. The gains and decent wages didn't just happen. They were fought for and won. And they can be taken away if solid unionism doesn't continue." To be fair, although some of the newer workers

\footnotetext{
${ }^{7}$ For a look at the rise of postwar affluence and the emergence of a consumer culture see Lizabeth Cohen, $A$ Consumers' Republic: The Politics of Mass Consumption in Postwar America, (New York: Vintage Books, 2003).

${ }^{8}$ See, for example, John Herling, Right to Challenge: People and Power in the Steelworkers Union, (New York: Harper \& Row, 1972).

9 “Ask The Man Who Knows" Steelabor, December 1956, 12.
} 
did not possess the life experiences of Greer or workers form his generation, postwar-era steelworkers would increasingly have legitimate grievances with their union, especially over issues such as union democracy and the union's responsiveness to the rank-and-file. ${ }^{10}$ Despite these issues, it cannot be overstated that Greer and the generation of steelworkers prior to World War II saw their lives significantly altered for the better due in part to the industrial union movement.

The pension and social insurance victory of 1949 marked the crest of the tidal wave of improvements wrought by the USWA from the Great Depression to the immediate postwar era. As we have seen in previous chapters, the historical path leading to the union's decision to bargain for private welfare security in 1949 was complex and influenced by many different events and issues. As will be evident in this chapter, although the union did achieve decent security through bargaining, the 1949 pension and social insurance program was not perfect and was deficient in many areas. Over the course of the 1950 s, the union attempted to ameliorate these deficiencies through collective bargaining with the hope of building a comprehensive and fully prepaid pension and social insurance program, while simultaneously promoting the expansion of public welfare security. Unfortunately, the possibility of enacting progressive legislation, especially legislation to create a national healthcare system was greatly curtailed due in part to a conservative postwar political environment, postwar anti-unionism, and the reemergence of welfare capitalism. ${ }^{11}$ Although the union made great strides toward their goal of

\footnotetext{
${ }^{10}$ See Philip W. Nyden, Steelworkers Rank-And-File: The Political Economy of a Union Reform Movement (New York: Praeger, 1984); Staughton Lynd, The Fight Against Shutdowns: Youngstown's Steel Mill Closings (San Pedro: Singlejack Books, 1982); Alice Lynd and Staughton Lynd "We Are All We've Got": Building a Retiree Movement in Youngstown, Ohio" in Gary Bellow and Martha Minow, eds., Law Stories. (Anne Arbor: University of Michigan Press, 1998).

${ }^{11}$ On the rise of postwar welfare capitalism see Sanford M. Jacoby, Modern Manors: Welfare Capitalism since the New Deal (Princeton: Princeton University Press, 1997); on the emergence and entrenchment of America's public private welfare state see Jacob S. Hacker, The Divided Welfare State: The Battle over Public and Private Social Benefits in the United States (New York: Cambridge University Press, 2002).
} 
a fully prepaid and comprehensive pension and social insurance system by the close of the 1950s, culminating in the 116-day 1959 Steel Strike, the issue of medical cost control disrupted that goal. Indeed, the issue of cost control manifested quickly after the 1949 contract, and by the end of the decade, caused the union to begin to reevaluate the efficacy of indemnity forms of insurance coverage by 1960 .

\section{The Fight to Improve the 1949 Pension and Social Insurance Program}

In November 1952, the US labor movement lost two giants with the deaths of American Federation of Labor president, William Green, on November 21, 1952, and the death of CIO and USWA president, Philip Murray, on November 9, 1952. Broadly speaking the death of these two union leaders opened the door for a new generation of leaders to guide the American labor movement in the postwar era. On one side, George Meany, a United Association plumber by trade, took over the mantle of leadership of the AFL, while Walter Reuther, president of the United Auto Workers, assumed the presidency of the CIO. By 1955 both leaders were able to look past the conflicts that had divided the labor movement since the 1930s and reunite the house of labor. ${ }^{12}$

At a national union level, the death of Philip Murray was a tremendous blow to the USWA. Murray had piloted the steelworker's union since 1936 when John L. Lewis appointed him the head of SWOC. Murray, who cut his teeth as a labor leader in the United Mine Workers of America (UMWA) throughout the teens and the twenties, carried his leadership skills into the new steel union and oversaw the rise of one of the most powerful, respected, and influential industrial unions upon his death. Within the union, Philip Murray was generally respected by the membership at all levels. Indeed, early in the life of SWOC and later in the USWA, many local

\footnotetext{
${ }^{12}$ Melvyn Dubofsky and Warren Van Tine, John L. Lewis: A Biography (Urbana: University of Illinois Press, 1986) 366; Robert H. Zieger, The CIO, 1935-1955 (Chapel Hill: University of North Carolina Press, 1995) Chapter 13.
} 
unions held a "Philip Murray day" out of reverence for their leader. ${ }^{13}$ As was highlighted in the previous chapter, in times of turmoil or struggle over issues of great importance such as the 1949 fight for pensions and social insurance, steelworkers often flocked to hear him speak, filling auditoriums and sports complexes. When Murray spoke, for instance, at formal USWA Executive Board meetings, USWA leaders listened to his counsel. Murray had an uncanny knack to get board members to see the larger strategic picture of what the USWA was attempting to accomplish; Philip Murray thus deserved a large measure of credit for leading the USWA to achieve unprecedented gains for not just USWA members but for all Americans.

Assuming the position of USWA president upon Murray's death was USWA SecretaryTreasurer, David J. McDonald. McDonald began his labor career as Murray's personal secretary in the UMWA in the 1920s, and he never left his side. He followed Murray into the SWOC in 1936 and quickly secured a significant leadership position as the union's secretary-treasurer. ${ }^{14}$ Here McDonald built his career as a union leader, putting himself in the line of succession to assume the presidency in 1953. McDonald was sworn in as USWA president at the March 11, 1953, IEB. Upon finishing his oath of office, he spoke to the board about how far the union had come since 1936 and where he believed the union should go in the future. He highlighted how the USWA had significantly increased the standard of living for its members and at the same time facilitated the expansion of "industrial democracy." ${ }^{15}$ McDonald focused in on the success of the American labor movement, which he, like Murray, believed differed from other forms of governments and other forms of labor systems around the globe. In particular, he rejected "totalitarian" forms of government declaring, "From the very start of the steelworkers organizing

\footnotetext{
13 “Celebrate First 'Phil Murray Day"” Steelabor, August 25, 1939, 8.

${ }_{14}^{14}$ David J. McDonald, Union Man (New York: E. P. Dutton \& Co., Inc, 1969) 32-34.

15 "President McDonald Charts Future Course of Union" Steelabor, April 1953, 6-7.
} 
committee, we rejected Marxism in all its forms, whether it was called Socialism, Fascism,

Nazism or Communism." ${ }^{16}$ Noting further that, "we have thus given the lie to the Communists, and we have proven to all of those who will just take a moment to consider that democratic capitalism, combined with industrial democracy, is without question the best way of life for mankind." 17

McDonald then went on to address specific things the union needed to do in the future. He called on the union to increase its political work and expand its PAC. He also made arguments for the need to establish Fair Employment Practices legislation at the city and state level, as well as workman's compensation reforms, and the expansion of unemployment and health and safety laws. Moreover, McDonald reinvigorated the call for the annual wage and the Industry Council Plan, both of which Phillip Murray championed. McDonald called on the union to expand its ranks and continue to facilitate cooperation with the steel industry if the steel industry reciprocated a cooperative attitude, a core USWA philosophy since its inception. ${ }^{18}$ Lastly, he argued that the union needed to continue to expand its pension and social insurance program in order to achieve the 1949 goal of establishing a fully comprehensive and prepaid program of security. ${ }^{19}$ David McDonald thus looked to pick up where Murray left off and lead

\footnotetext{
${ }^{16}$ Ibid, 6.

${ }^{17}$ Ibid; as we have seen McDonald and Philip Murray both viewed communism as a "totalitarian" political philosophy not compatible with American democratic institutions and to some degree their characterization of some communist governments, for instance the Soviet Union, conformed to that characterization. However, communist movements in the United States have a more complex history. Indeed, many communist unions were very democratic and active promoters of equality and civil rights as seen for instance in Robert Rodgers Korstad, Civil Rights Unionism: Tobacco Workers and the Struggle for Democracy in the Mid-Twentieth-Century South (Chapel Hill :The University of North Carolina Press, 2003); Also, although the economic theories of Karl Marx have been used by some countries and organizations in an authoritarian or totalitarian manner, Marx's study of American capitalism remains one of the most profound and influential critiques of the capitalist system. Moreover, throughout the postwar era new Marxian scholars have been critical of totalitarian uses and interpretations of Marxian political economy and have offered new interpretations that promote local decentralized economic democracy through worker coops and the collective ownership of the enterprise by the workers see for example Richard D. Wolff, Democracy at Work: A Cure for Capitalism (Chicago: Haymarket Books, 2012).

${ }^{18}$ Ibid, 6-7.

${ }^{19}$ Ibid.
} 
the USWA into what seemed at that moment to be a bright and boundless future secured by the promise of "democratic capitalism."

In the summer of 1951, the union published statistics highlighting its pension and social insurance program after its first year of operation. By July 19518,500 basic steel USWA members had retired on the 1949 pension plan with "a couple of thousand" retiring at smaller steel concerns around the country. ${ }^{20}$ These retirees were now enjoying a pension of substance that provided for a steelworker's financial security in retirement. Moreover, members who retired prior to 1949 also saw increases in their pension levels. ${ }^{21}$ Steelabor also highlighted that the 1949 contract was not just beneficial for blue collar union members. In fact, after the 1949 victory, even nonunion supervisory and managerial workers began receiving pensions and other benefits. $^{22}$

The 1949 social insurance program, in particular, the hospitalization program, impacted the lives of thousands of USWA members and their families. Over the first year of operation, 263,000 steelworkers used their hospitalization benefits amounting to $\$ 30,146,000 .^{23}$ As of 1951, the USWA hospitalization plan was split almost evenly between hospitalization provided by Blue Cross and hospitalization provided by private insurers. The contracts that had Blue Cross coverage were at US Steel, Bethlehem Steel, Jones \& Laughlin, Timken, Crucible Steel, Sharon Steel, and the Pickands Mather \& Company. Within this Blue Cross cohort, over 485,000 steelworkers and their families had hospitalization coverage with Blue Cross. Of these, 138,000 used their coverage at a total cost of $\$ 15,336,000 .{ }^{24}$ Steelworkers at Republic Steel,

\footnotetext{
20 “8,500 USA members Retired in Basic Steel under Pension Plan,” Steelabor, July 1951, 3.

${ }^{21}$ Ibid.

22 Ibid.

23 “\$30, 146,000 Paid in Hospital Benefits Under USA-Industry Insurance Program,” Steelabor, May $1951,3$.

24 Ibid.
} 
Inland Steel, Youngstown Sheet \& Tube, Wheeling Steel, and Pittsburgh Steel, had hospitalization coverage through a private commercial insurer. Within this cohort, over 440,000 steelworkers and their families had hospitalization coverage. Of these, 125,000 used their benefits in the first year at a total cost of $\$ 14,810,000 .^{25}$

By 1951 the union's life, sickness, and accident insurance program was also in full operation. In the first year of the program over $\$ 30$ million was paid out in both life insurance and sickness and accident insurance. Of the $\$ 30$ million, $\$ 15,440,000$ in life insurance was paid in the first year. More specifically, at Bethlehem Steel 649 of 100,000 workers died during the first year of the program, 179 of which had less than 10 years of service. ${ }^{26}$ Indeed, for these unfortunate younger workers, the 1949 life insurance plan ensured that their families would have some financial security in the wake of their passing. Lastly, throughout the steel industry over 112,700 workers used their sickness and accident benefits in the first year of the program. ${ }^{27}$

The fruits of the 1949 victory were very apparent by 1951, working to improve the lives of steelworkers and their families. Despite this success, a host of issues lingered within the 1949 program. For instance, the program lacked coverage for dental and eye care, it made steelworkers pay for half of the social insurance premium, and it increasingly failed to keep medical costs in check. In terms of pensions, the early years of the program allowed employers, rather than retirees, to benefit from any increases in the social security old age pension program. These and other issues were not lost on USWA leaders, and eradicating these deficiencies became bargaining priorities throughout the 1950s. In fact, one of the first social insurance

\footnotetext{
25 Ibid.

26 “29,349,000 Paid in Life Insurance, Sickness and Accident Benefits,” Steelabor, June 1951, 3.

27 Ibid.
} 
deficiencies, the lack of surgical benefits coverage, became priority number one as the ink dried on the 1949 contract.

By 1951, the 1949 social insurance fund at US Steel had accumulated an 8-million-dollar surplus. ${ }^{28}$ The accumulation of funds in such large amounts opened the door for USWA leaders to push US Steel to expand the social insurance program by adding a Blue Shield surgical plan to the overall welfare security program. Like Blue Cross insurance, which provided hospitalization coverage, Blue Shield insurance covered a worker's surgical costs on an indemnity (cost reimbursement) basis. That is, the program established a cost list per procedure that would be paid to the medical practitioner. For example, Blue Shield might pay $\$ 25$ for a broken arm or $\$ 100$ for an appendectomy.

For USWA leaders, pushing US Steel for a surgical benefits program was the next logical step in pursuing its goal of building a comprehensive program of benefits. In fact, many steelworkers prior to the Blue Shield program were individually buying surgical coverage for their families. At US Steel alone over 120,000 steelworkers were purchasing surgical insurance coverage at a cost of $\$ 1.50$ a month in order to supplement and expand the coverage they had under the 1949 contract. $^{29}$

Throughout the first half of 1951, the USWA worked out an agreement with US Steel for a Blue Shield surgical plan. The plan did not change the joint financing arrangement agreed to under the terms of the 1949 contract. Thus, steelworkers would continue to pay half of the social insurance premium. Moreover, since the financing of surgical benefits was built on the accumulated surplus of the 1949 program, the agreement stipulated that if the surplus ever fell

\footnotetext{
28 "And Now... Surgical Benefits in US Steel; 715,000 to get surgical Benefits Under Agreement of USA-CIO and US Steel," Steelabor, August 1951, 1,3.

${ }^{29}$ Ibid, 3 .
} 
below $\$ 4$ million, steelworkers would have to pay 50 cents a month to keep their surgical coverage. ${ }^{30}$ As was the case in most instances of postwar collective bargaining agreements, once US Steel agreed to a surgical benefits plan, surgical benefits were quickly adopted throughout the steel industry. With this victory, the steelworkers took a mammoth step forward in the union's pursuit of establishing a comprehensive social insurance program for its members.

As early as 1953 it had grown increasingly clear to union members and union leaders alike that the pension and social insurance program was deficient on numerous levels and needed to be overhauled. To more fully categorize the social insurance program's deficiencies and to gauge the mood of union members, the union scheduled a three-day special Wage Policy Committee (WPC) meeting in November 1953 called "Operation Sound-Off."31 The goal of the Operation Sound-Off was to help deliver what District 16 union members labeled a "peace of mind" pension and social insurance program to be won in 1954 negotiations..$^{32}$ The pension discussion at Operation Sound-Off touched on a number of pension issues ranging from the current size of pensions to one of the first references to "vested rights" for pensioners. Bernard Greenberg, a USWA staffer and pension and social insurance expert, offered the committee his analysis of the current pension system. One of the most obvious problems with the pension system according to Greenberg was pension levels. The initial 1949 pension and social insurance program was a five-year deal, which meant that the union had to wait until 1954 to make changes to the program. Consequently, by 1953, the pension system had fallen behind the cost of living increases of the first half of the 1950s. In concluding his remarks on the impact of

\footnotetext{
${ }^{30}$ Ibid, 1,3 .

31 “Operation Sound-Off!: 1949 Insurance program was a Great Triumph but Obsolete Now" Steelabor, November $1953,2$.

32 “Guaranteed Wage, Improved Pensions by Dist. 16 Delegates,” Steelabor, November 1953, 10.
} 
inflation Greenberg stated, "Today we have thousands of former steelworkers trying to exist on benefits they were entitled to three or four years ago."133

Greenberg's analysis was echoed by other Wage Policy Committee members. Paul Hilbert, representing local union 3604, spoke to the need for increased pension levels noting, "Most of the members that I represent are talking about a lot more than $\$ 100$ a month, over and above social security." 34 J. Hoyt Hall, Jr., an ore miner representing Local 4200, Birmingham, Alabama, added to the voices calling for the expansion of pension levels. His motivation for increased pension levels was not based solely on his ability to make ends meet, but more importantly, Hall argued, that higher pension levels meant the possibility of an earlier retirement, and consequently, better quality of life in a steelworker's retirement years. Hall declared, "Pensions are one of the most important things to those of us who work in the ore mines. We want something so we can come up out of the mines and retire early enough to live a few years." 35

Beyond the need to expand pension levels, the WPC members discussed the issue of pension formula equity. The current pension formula governing pension levels throughout most of the steel industry was based on the average monthly pay of a steelworker over a period of 120 months (10 years). On the surface, the formula seemed equitable, however, as steelworkers, especially older steelworkers approaching retirement age often found, it fell far short of equitable. Peter Benson, representing Local Union 2157, in Hurley, Wisconsin, highlighted the downside of the current pension formula noting, "when a miner gets around 50 years or so he seeks a job on the surface — and often winds up with a lower-paying job the last 10 years he

\footnotetext{
33 "Steel Union Wants to Blaze New Trails in Retirement Benefits," Steelabor, November 1953, 2.

${ }^{34}$ Ibid.

${ }^{35}$ Ibid.
} 
works." 36 Consequently, his pension payment was calculated using a wage much lower than the wage he had received in his prime working years. Due to these types of life stage job changes, which happened throughout industrial workplaces across the country, Benson argued that a "worker's best 10 years...be used to figure his pension." 37

Another pension issue that reverberated throughout the Wage Policy Committee, was the 1949 pension policy that combined public social security payments with the private pension formula. As mentioned earlier, steelworker leadership, especially Philip Murray, believed that their efforts to win a pension and social insurance system via collective bargaining pushed industry leaders into supporting the expansion of the social security system in the first half of the 1950s. This argument does have some merit, considering that previous efforts to expand social security had failed throughout the 1940s. Over that period Congress persistently refused to increase the funding of the program. ${ }^{38}$ The 1949 contract which established a company funded private pension for steelworkers, also integrated public social security payments into the overall pension formula. ${ }^{39}$ The 1949 contract allowed the company to reduce its pension liability if and when the Congress voted to increase social security payments. This is exactly what happened after the social security amendments of the early 1950s. Retirees under the 1949 contract received a $\$ 100$ a month pension composed of a social security payment as well as a company pension payment. As a hypothetical example, under that contract, a retiree might receive $\$ 50$ dollars a month from social security and thus the company would be liable for a pension payment of $\$ 50$ dollars a month, which brought the retiree's monthly pension payment

\footnotetext{
${ }^{36}$ Ibid.

37 Ibid.

${ }^{38}$ Edward D. Berkowitz, America's Welfare State: From Roosevelt to Reagan (Baltimore: Johns Hopkins University Press, 1991), 39-65.

39 “Steel Union Wants to Blaze New Trails in Retirement Benefits," Steelabor, November 1953, 2.
} 
to $\$ 100$ a month. However, the 1949 contract stipulated that if the government increased the social security payment, the company's pension liability would decrease. Given our earlier example, if the government increased the minimum social security payment to $\$ 75$ a month, the company's pension obligation decreased to $\$ 25$ a month, as the company only had to make up the gap in social security in order to provide for a $\$ 100$ dollar a month composite pension. WPC member Sam Camens, representing Local Union 1330, Youngstown, Ohio, argued against the practice of offsetting the private pension with social security. Camens declared that "when we first negotiated the [pension] program the companies were faced with paying about $\$ 65$ a month of the $\$ 100$ [pension] minimum. The increase in social security left them with only about $\$ 15$ to pay." Thus, Camens emphatically concluded, "Let's have at least $\$ 100$ on top of Social Security."40 Stanley Bigda, representing a steelworker local from Hammond, Indiana, reinforced Camens' argument advising the WPC that "pensions should be strictly divorced from social security."41

Operation Sound-Off also addressed the various deficiencies within the 1949 social insurance program. John Tomayko, head of the USWA pension and social insurance department took the floor to offer his analysis of the current program. Tomayko characterized the program as "wholly inadequate." He blamed the program's inadequacy on its piecemeal construction. For instance, in 1949 the union did not have the power to dictate its own terms in collective bargaining, hence union leaders had to compromise with industry officials. The industry demanded that the insurance program be financed on a joint basis, that is a system in which industry paid for one-half of the premium and the worker paid for the other half of the premium. Not wanting to burden union members with extra costs beyond their half of the financial

\footnotetext{
40 Ibid.

${ }^{41}$ Ibid.
} 
contribution, the union was left in a position where the contents of the social insurance program had to be purchased from a predetermined pot of money. Thus, rather than starting with maximum coverage and bargaining to win company financing for that coverage, the union started with a predetermined fund and then purchased the best insurance coverage they could with the money available. This fact, Tomayko explained, left gaps in the social insurance program. He thus declared, "The 1949 agreement was not limited because we felt that the protection we won was all that Steelworkers were entitled to have. We had to buy all we could with what little we had to spend." ${ }^{2}$ Moreover, Tomayko announced, "Since [1949]..., medical and hospital costs have gone up so rapidly, the present program is simply not meeting the needs of the people." 43

Medical costs were indeed rising fast, and rank and file steelworkers were intimately aware of it. Steelabor summarized the feeling that the rank and file had toward rising medical costs, noting that they "blasted [the] 'deplorable practices' of some surgeons and hospitals who have attempted to get rich quick at the expense of steelworkers who are covered by programs." 44 WPC member John Grajciar, representing District 21 from Sharon, Pennsylvania relayed a story about increased hospital fees at one hospital in the Sharon region. According to Grajciar, prior to the 1949 contract, the hospital in question charged a rate of $\$ 6$ dollars a day. The 1949 contact provided steelworkers from the Sharon district \$7 dollars a day for hospitalization. Rather than accepting the $\$ 7$ dollars as paid in full, within 30 days of the 1949 contract the hospital raised its rate to $\$ 8$ dollars a day. Thus, steelworkers needing hospitalization were forced to pay an out of

\footnotetext{
42 “'Operation Sound-Off!': 1949 Insurance program was a Great Triumph but Obsolete Now,” Steelabor, November 1953, 3.

43 Ibid.

44 Ibid.
} 
pocket cost of $\$ 1$ dollar. ${ }^{45}$ Stories such as these proliferated steel communities throughout the nation, putting greater strain on a steelworker's ability to make ends meet in the event of a family medical crisis. Charles R. Lockett, a steelworker from Detroit, observed that increasing medical costs were forcing many steelworkers to reduce and/or forgo medical treatment. Lockett told the committee that increased medical costs, "can be such a hardship that a man will try to return to work before his recovery is complete. ${ }^{46}$ Joe D’Alasio, a steelworker from Midland, Pennsylvania commented before the WPC that, "the companies insure machinery to the fullest extent. Why shouldn't they give full protection for the worker?"47 D'Alasio's observation harkened back to the "People Like Machines Wear Out" campaign of 1949, highlighting that the mantra of that campaign had yet to be fully realized.

The phenomenon of rising hospital and doctors' fees greatly troubled the union. In essence, it developed as follows: The steelworkers in 1949 contracted for Blue Cross hospitalization coverage and/or hospitalization through a private insurer, and in 1951 they won a Blue Shield surgical plan. Both Blue Cross and Blue Shield set particular medical payment rates. Although the steelworkers were fortunate enough to use their collective power to secure what at the time was thought to be a comprehensive prepaid medical insurance plan, the free enterprise system shattered those notions. In the private market where both doctors and hospital administrators were free to charge rates that the market would bear, they often charged over and above the insurance reimbursement rate, leaving individual steelworkers to pick up the tab.

Granted, not all hospitals and doctors charged extra fees over and above the reimbursement rate; however, the practice was becoming commonplace and very noticeable to steelworkers and their

\footnotetext{
${ }^{45}$ Ibid.

${ }^{46}$ Ibid.

${ }^{47}$ Ibid.
} 
families. In fact, according to Bernard Greenberg, some unscrupulous doctors were charging steelworkers 100 percent above what their insurance paid. ${ }^{48}$ USWA leaders never anticipated that doctors or hospitals would increase their rates over and above the prescribed insurance indemnity. Consequently, within a market system that stressed individual freedom of both doctor and patient, the union found it difficult to remedy the situation. The issue of cost continued to plague the union's social insurance programs throughout the 1950s. Indeed, both Tomayko and Greenberg in 1953 were beginning to understand the many deficiencies associated with indemnity insurance coverage and they "emphasized that the cooperation of the nation's doctors would be necessary before any effective program could be set up." 49

By the close of Operation Sound-Off, the WPC had crafted a list of suggestions to guide the union leaders in steel negotiations slated for 1954. The WPC determined that the entire pension system needed "to be expanded," and that the pension formula needed to be more equitable in order to benefit the retired steelworker. Moreover, the WPC agreed that the union should work to divorce the social security payments from the private pension system formula, which would allow steelworkers, rather than the steel employers, to absorb any future benefit increases in the federal social security program. ${ }^{50}$ With regard to the social insurance program, the WPC agreed to work on cost control, expand hospitalization coverage, especially hospitalization time limits, pursue the establishment of a dental insurance plan, and work to get local union members on the boards of local hospitals. ${ }^{51}$ Finally, the WPC resolved to focus on

\footnotetext{
${ }^{48}$ Ibid.

49 Ibid.

50 “Steel Union Wants to Blaze New Trails in Retirement Benefits," Steelabor, November 1953, 2.

51 “'Operation Sound-Off!': 1949 Insurance program was a Great Triumph but Obsolete Now," Steelabor, November $1953,3$.
} 
retiree issues, particularly by “providing active, useful opportunity to the country's retired 'senior citizens."

In sum, Operation Sound-Off was a momentous event in USWA history. It highlighted that steelworkers from the top of the union hierarchy to the everyday rank-and-filer were not fully satisfied with the 1949 pension and social insurance program. However, their concern with the program was not based on a belief that private insurance and the free enterprise system was somehow structurally deficient. Indeed, David McDonald believed that the 1949 contract "was still one of the greatest social advances ever made for the people of America." ${ }^{53}$ Furthermore, both McDonald and USWA counsel, David Goldberg, argued that Operation Sound-Off proved to be a healthy event for the union that conformed to past union precedent of never settling and always striving for better. Operation Sound-Off thus proved to McDonald that the USWA was at its core "a progressive organization." ${ }^{54}$ With the close of Operation Sound-Off the union turned its sights on vocalizing its displeasure with the rising cost of medical insurance as well as improving the current pension and social insurance program in 1954 bargaining.

Before turning to the 1954 negotiations, USWA leaders attempted to shine a light on the issue of medical costs by voicing their concerns to the medical and insurance community. In May 1953 David McDonald was invited to speak at the National Blue Cross/Blue Shield conference. McDonald opened his remarks by underscoring areas of the USWA's Blue Cross/Blue Shield plan that could be improved and expanded. For example, the USWA president called for longer hospitalization periods, longer maternity care periods, and for "early diagnostic and preventative medical care."55 Beyond calling for expanded benefits, McDonald

\footnotetext{
52 "Steel Union Wants to Blaze New Trails in Retirement Benefits," Steelabor, November 1953, 2.

${ }^{53}$ Ibid.

${ }^{54}$ Ibid.

${ }^{55}$ David McDonald, "Your Union's Health Care Objectives” Steelabor, May 1953, 5.
} 
also made clear his growing concern with rising medical costs. He informed the crowd of onlookers that steelworkers were quickly discovering that their insurance did not always cover one hundred percent of their medical bills. McDonald did acknowledge that ever since 1949 the cost of most commodities in the country had risen; however, something else was at the heart of the rise in medical costs. In fact, McDonald accepted the idea of increased costs associated with a growing economy, such as increased costs due to higher wages and salaries for medical personnel as well as the costs associated with technological advancement and research and development. However, McDonald underscored the point that the rising cost of medical care in the United States was not merely a factor of prosperity. Instead, he pointed the finger at hospital administrators for charging "unnecessary fees" and doctors who charged fees above and beyond the insurance fee schedule. For McDonald, these two factors were at the heart of rising medical costs and he called on the conference to address the issue. ${ }^{56}$

McDonald went on to highlight that when the union first instituted private social insurance coverage in 1949, the organization was under the impression that they were receiving prepaid medical coverage -- coverage he defined as insurance, "which provides for the advance collections of premiums to establish a fund from which is paid participant's bills in full for the range of services covered by the plan." ${ }^{57}$ McDonald ended his remarks declaring that the steelworker "wants to have a prepaid hospital and medical plan as I have defined it,...I believe he is entitled to it." 58 Further, he noted that the union was "convinced that healthcare cannot be translated into fixed dollar values." Despite this statement, McDonald did confirm his allegiance

\footnotetext{
56 Ibid.

57 Ibid.

58 Ibid.
} 
to the free enterprise system and the "pattern of medical practice in our country," which promoted "private practice and freedom of choice for the patient." 59

One option that the steelworkers could turn to was politics, especially using their political power to push for a national healthcare system, or at the very least pass legislation that would provide federal healthcare to retirees and the indigent. Indeed, throughout the $1950 \mathrm{~s}$, union leaders never lost sight of that progressive goal. However, the political environment throughout the 1950s greatly limited the union's ability to enact progressive legislation such as national healthcare. In addition, the union faced increased attacks from the conservative right as they mobilized around the Taft-Hartley Act to attack labor at the state level. Moreover, as steelworkers gained private welfare benefits in 1949, and enhanced those benefits throughout the 1950s, rank-and-file enthusiasm for the expansion of the public welfare state did not materialize outside of steelworker support and advocacy of national health insurance for retirees and the indigent, which worked to more firmly solidify the emergence of the United States bifurcated public-private welfare state.

\section{0s Politics and Public Welfare}

In September 1953 the USWA IEB held a serious discussion about the current state of politics in the United States and what that meant for the prospect of enacting progressive legislation. Legislative Director Hoffman kicked off the session speaking to the union's relationship to the President Eisenhower and the anti-union efforts beginning to mobilize against the steelworkers and the labor movement as a whole. Hoffman argued that a concerted effort, ranging from the President on down was pushing a state's rights agenda and mobilizing to

\footnotetext{
${ }^{59}$ Ibid.
} 
expand right to work on a state by state basis. ${ }^{60}$ Hoffman noted that the future looked bleak for the passage of progressive legislation on a federal level. He subsequently read to the board what appeared in the IEB proceedings as an unnamed newspaper source. Hoffman stated,

Let me read you something that happened just yesterday, September 16. This says: 'President Eisenhower plans to go States' Rights with a vengeance, especially when it comes to putting each state on its own in regard to social security, old age pensions, public roads, power dams and other projects which siphoned more money to the South under 20 years of Democratic rule than at any time during history., ${ }^{61}$

Hoffman then reiterated that forces were mobilizing to push right-to-work across the country declaring, "That is just the beginning. This is an organized plan. It is an organized plan and it is being organized right down to the T." 62 As for the current political environment facing the union in 1953 and the foreseeable future Hoffman emphatically declared, "Your Federal Congress is not going to give you anything this year or next year which would in any way enhance the position of the steelworkers and their families at home. Get that clear!"63

Director Walsh from Massachusetts argued the union should pursue a state level political strategy and subsequently offered his contempt for the union's federal level strategy. In blunt term Walsh opined, "I never did think too much of the CIO program, having a lot of big liberals spend all of our money at the Federal level." ${ }^{\prime 64}$ Walsh argued that a state level strategy would be

\footnotetext{
${ }^{60}$ On the state level conservative anti-union assault on labor in the 1950s see Elizabeth A. Fones-Wolf, Selling Free Enterprise: The Business Assault on Labor and Liberalism, 1945-60 (Urbana: University of Illinois Press, 1994) Chapter 9; also, throughout the 1950s Steelabor was full of articles pertaining to the right-to-work movement and how anti-labor forces were actively seeking to undermine the Steelworkers and the American labor movement, see, for instance, "Abel Warns District 31 Delegates American Democracy is in Danger" Steelabor, November 1958, 5; "The War on Unions: Never Before Have Lawmakers Been Snowed Under by a Comparable Barrage of Anti-Union Propaganda" Steelabor April 1958, 8-9; "Wage Earners Beware!: Union Busters Using Patriotism to Kill Collective Bargaining, Watch for California Pattern to Come Alive in Other Areas" Steelabor, November 1957, 15; "Are People Living too 'High' to See Dangers In Wreck-Union Laws?: Youngster Looks Behind Right-to-Work Conflict" Steelabor, October 1957, 3; "McDonald Sounds Warning--Political Action or Sink: 'What Faces Labor Today is Battle for Survival"' Steelabor, October 1957, 2; "Need 'Every Dime' to Combat Attack on Labor, Able Tells Conferences" Steelabor, October 1957, 2.

${ }^{61}$ IEB, September 16-17, 1959, Box 45 Folder 6, 81.

${ }^{62}$ Ibid.

${ }^{63}$ Ibid, 84.

${ }^{64}$ Ibid, 88-89.
} 
more appealing to his constituents than a federal strategy adding, "you can't do that if you are trying to get your people concerned about matters that are a thousand miles away from them. But give them the right-to-work laws, workmen's compensation and things of that kind and they will learn a lot about it and get so interested that they will really go out and put the heat on these legislatures."65 Some directors agreed generally with the strategy but pointed out that racial issues in Southern states would prevent the passage of FEPC type legislation and that a state level strategy would be unwieldy in terms of enacting uniform workplace safety laws. ${ }^{66}$ McDonald ended the board's discussion of politics noting that the USWA would never abscond from Federal level politics; however, the political realities of the day forced the union to concern itself more at the state level. Adding further, "We are certainly not intending to give up our fights on any of these issues at the national level."67

With that said the board subsequently gave its unanimous support to a state level political strategy. ${ }^{68}$ The strategy was to focus on the state level to, (1) prevent anti-labor legislation from being enacted and (2) to promote a progressive legislative agenda at the state level that would hopefully in the future "transmit that interest into your Federal Congress." 69 Lastly (3) the USWA would focus on running union members at the state level and support other labor friendly candidates for state office. $^{70}$

\section{Bargaining for Increased Private Security, 1954-1957}

With no hope of passing progressive public welfare legislation at the federal level the union throughout the 1950s relentlessly pursued its goal of establishing a fully pre-paid and

\footnotetext{
${ }^{65}$ Ibid, 90.

${ }^{66}$ Ibid, $90-91$.

${ }^{67}$ Ibid, 91.

${ }^{68}$ Ibid, 93.

${ }^{69}$ Ibid, 84.

${ }^{70}$ Ibid, 85.
} 
comprehensive system of pensions and social insurance benefits. Time and again their efforts proved fruitful as the union made significant bargaining gains first in 1954, then in 1956 and 1957. In each of these bargaining sessions, the union came away with more coverage for its members bringing the union closer to its original goal, but also further and more detached from the goal of expanding federal public welfare.

The 1954 negotiations witnessed several improvements to the 1949 pension and social insurance program. Not only did the union secure a 5 cent an hour wage increase for its members it also won an increase in the minimum pension benefit, which brought the minimum monthly pension from $\$ 100$ to $\$ 140$ a month. Moreover, employers also agreed to raise the disability pension to a minimum of $\$ 75$ a month. As for social insurance, the contract allowed for an increase in the overall funding of the social insurance program up from 5 cents an hour to 9 cents an hour split evenly between employer and employee. ${ }^{71}$

Contract bargaining in 1954 also marked a significant shift in pension funding that would benefit the financial security of USWA retirees for years to come. The new contract addressed the social security offset built into the 1949 pension formula. Although the contract did not totally eliminate the offset it did establish a social security cap of $\$ 85$ a month that would ensure that future social security increases went to retirees rather than employers. ${ }^{72}$ The benefits of this provision became quickly apparent as the social security amendments of 1954 raised the max social security payment from $\$ 85$ to $\$ 98.50$. Consequently, the retiree rather than the employer secured the fruits of the increase. For instance, the 1954 contract established a $\$ 140$ minimum pension composed of $\$ 85$ a month from social security and $\$ 55$ a month from the company. With the social security offset capped at $\$ 85$ a month, the increase in social security to $\$ 98.50$

\footnotetext{
71 “Union Wins-12-Cent Package” Steelabor, July 1954, 3.

72 “Here's Why Steelworkers Can Face the Future with Far Greater Confidence” Steelabor, November $1954,3$.
} 
ensured that the retiree received $\$ 140$ a month as stipulated in the contract along with the extra $\$ 13.50$ a month from the social security increase. Due to the 1954 contract, retirees would now secure the fruits of all future increases in social security. ${ }^{73}$

In 1956 the union looked to make increases to the pension and social insurance program where contractually applicable as well as to pursue the creation of a Supplemental Unemployment Benefits (SUB) program. The demand for SUB was the most significant demand of 1956 and was the demand most connected with Philip Murray's long-time goal of establishing an annual wage in the steel industry. In essence, SUB was a private form of unemployment insurance. For example, when a worker was laid off in the 1950s, that worker was eligible for federal unemployment compensation, which provided temporary supplemental income to keep a worker finically solvent until he or she was called back to work or found new employment. However, federal unemployment was limited and did not cover a worker for a year. SUB was a private form of unemployment insurance designed to extend and bolster federal unemployment compensation to financially secure an unemployed steelworker in a period of long-term unemployment. The SUB program would ensure a guaranteed annual subsistence wage for unemployed steelworkers, or as USWA President David J. McDonald put it, a SUB plan would "keep the wolf from the door in times of adversity."74

In 1955 the union did have some success in negotiating SUB plans at both the American Can Company and the Continental Can Company. ${ }^{75}$ With those victories, the union believed it had an opportunity to secure SUB plans in basic steel in 1956. Although it took a brief strike to get recalcitrant basic steel companies to accept a SUB program, the union was victorious in

\footnotetext{
73 “Social Security and You!" Steelabor, December 1954, 4-5; "Here's Why Steelworkers Can Face the Future with Far Greater Confidence" Steelabor, November 1954, 3.

74 “We Strike for Fairness Against Greed” Steelabor, July 1956, 2.

75 “We Win Supplemental Unemployment Compensation Benefits” Steelabor, September 1955, 2.
} 
codifying SUB as part of the 1956 basic steel contract. Beyond SUB, the union was also able to expand and modify some parts of the 1954 social insurance contract. For instance, the union won an end to cent per hour financing of the social insurance fund and, instead, established a fixed contribution system of $\$ 19$ dollars a month split evenly between the employer and employee. ${ }^{76}$ This was significant because a fixed funding policy rather than a cent per hour policy ensured that the company paid into the system even during periods of unemployment. Under the earlier scheme, if a steelworker was not working the company did not pay into the fund for that worker, and thus, the possibility existed that in a period of recession or depression the social insurance fund might become insolvent.

The 1956 contract also initiated an effort to more fully standardize the pension and social insurance system amongst the various steel concerns that made up basic steel. ${ }^{77}$ Moreover, the contract saw general program increases in the life, sickness, and accident programs. The sickness and accident plan was put on a "graduated" reimbursement basis that paid weekly benefits based on a steelworker's hourly wage rate rather than a one size fits all flat rate. ${ }^{78}$ Lastly, the union was able to expand its Blue Shield surgical coverage, raising the max reimbursement from \$200 to $\$ 300$. At the time the USWA believed this increase might solve the issue of medical cost inflation and eliminate out of pocket costs for their members. ${ }^{79}$ However, increased reimbursement rates only exacerbated medical cost inflation.

Beyond the social insurance improvements of 1956, the USWA won various contract provisions that broadened and expanded the pension system in late 1957. The contract allowed for pension increases for active and retired steelworkers as well as the establishment of "vested

\footnotetext{
76 “"Security Offensive!” Steelabor, November 1956, 5.

${ }^{77}$ Ibid.

${ }^{78}$ Ibid.

${ }^{79}$ Ibid, 12.
} 
pension" rights for workers permanently laid off who were at least 40 years old and had at least 15 years of service. These permanently laid-off workers could now claim a reduced pension from their former employer when they reached the age of 65 . Moreover, the contract allowed for early retirement at the age of 60 at a reduced pension rate. ${ }^{80}$ Finally, the 1957 pension deal raised the minimum pension for a single worker to $\$ 180.50$ a month at age 65 or older and $\$ 234.80$ a month for a married steelworker age 65 or older. ${ }^{81}$

These improvements benefitted steelworkers, but again, simultaneously diminished any desire or urgency to pass national healthcare legislation. Improvements such as the ones described above did not completely detach steelworkers from public welfare, for all steelworkers in retirement would benefit greatly from increases in the old age pension system. However, it did diminish any enthusiasm for mobilizing politically around a campaign to enact a national healthcare system. USWA source material up to this point- - the IEB record, convention proceedings, and Steelabor — highlight that rank-and-file members from the postwar period through the 1950s were very active and opinionated about their private welfare benefits, and at the same time rather unopinionated and detached from the public welfare debate. As we will see throughout the era of affluence the major public welfare activity on the part of rank-and-file steelworkers will come in the form of supporting national health insurance for retirees and the indigent.

\section{Building a Relationship with Retirees and the Menace of Rising Medical Costs}

By the mid-1950s the USWA began a concerted effort to more fully engage with their growing retiree base. Although no longer dues-paying/voting members of the union, USWA retirees were still a significant political voting block for the union and would always be tied to

\footnotetext{
80 “The Union Comes Through for Pensioners" Steelabor, November 1957, 6.
}

${ }^{81}$ Ibid. 
the union through the union's pension and benefits system. Indeed by 1956, retiree issues had grown in importance for the union so much so that the convention of that year authorized the creation of the "Committee on Retired Workers" headed by Nathan E. Cowan. ${ }^{82}$ The new department marked the first formal department within the union bureaucracy that stood outside of the pension and social insurance department and specifically focused on retiree issues. The union argued for the new department noting,

Thus far there has been a failure to provide meaningful roles for those who have passed the commonly accepted period of usefulness, and entered their retirement. Our great objective is to gain acceptance of the concept of these years as a period of productive and useful activity. We want to foster a sound environment in which these people may enjoy the greatest possible measure of good health, self-realization and independence throughout their later years. ${ }^{83}$

Throughout the 1950s demographic statistics revealed that the retiree age population of the nation was growing rapidly. According to USWA statistics, in 1958 there were over 15 million US citizens age 65 or older, which equated to a rate of 1 in 12 . From 1950 to 1958 the 65 and older population was expanding yearly by 350,000 and statisticians were estimating that the retiree age cohort would reach 21 million by $1975 .{ }^{84}$ The ranks of steelworker retirees had swelled to 80,000 by $1958 .{ }^{85}$ As was evident by the late 1950 s, the retiree population was expanding rapidly, which meant that the union's relationship with retired steelworkers would become increasingly more significant as the union fought for its future political and bargaining goals.

As the USWA took steps to connect with its retired members through the Committee on Retired Workers, so too did USWA districts and locals. By 1958, half of all USWA locals had

\footnotetext{
${ }^{82}$ USWA Convention Proceedings, 1958, 200.

${ }^{83} \mathrm{Ibid}, 201$.

${ }^{84}$ Ibid.

${ }^{85} \mathrm{Ibid}, 202$.
} 
established some type of formal relationship with retirees. ${ }^{86}$ For instance, 39 percent of locals offered post-retirement counseling, 26 percent offered pre-retirement counseling, and 25 percent offered recreational facilities or other activities for their retired members. ${ }^{87}$ In fact, District 31 in the Chicago region developed in conjunction with the national union and the University of Chicago, a 13-week pilot program designed to help prepare retirees for retirement. The program was open to all steelworkers and their spouses and covered issues such as "understanding the problems of older people," finding value and worth in retirement, financial planning, healthy living, medical issues, social interaction, family issues, housing, and the retirees' relationship to the union. ${ }^{88}$ In fact, the findings of the program were reproduced in summary form for all steelworkers to read in a monthly series printed in Steelabor. ${ }^{89}$

Beyond large-scale programs such as the District 31 pre-retirement program, some districts offered their retirees periodic question and answer meetings. For example, in the summer of 1957, USWA District 9 director C. B. Newell held a two-day question and answer session for retirees of Bethlehem Steel. Hundreds of retirees attended the meeting and participated by asking questions about current benefits programs as well as discussed issues with the current program and offered recommendations for the program's improvement. District 9 ensured that retirees would be privy to the most current and competent information by inviting representatives from the USWA pension and social insurance department, the Social Security administration, Blue Cross and Blue Shield, the VA, and the IRS. ${ }^{90}$ When asked about the efficacy of such a meeting Director Newell stated that "the pensioner is not a forgotten man

\footnotetext{
86 Ibid.

${ }^{87}$ Ibid, 203.

88 “The Steelworker Faces Retirement” Steelabor, May 1958, 8-9; USWA Convention Proceedings, $1958,204$.

89 “The Steelworker Faces Retirement" Steelabor, May 1958, 8-9, and same title used for series of retirement articles in June, July, August, and September 1958.

90 “"I Am a Pensioner..." Steelabor, August 1957, 12.
} 
insofar as we of the union are concerned! We will strive, in future negotiations, to make advances in their behalf. And we lean on these veterans in our effort to make a better community and to safeguard our union for the younger men." ${ }^{91}$

At the local union level, the union's relationship with its retirees often came in the form of various social events such as banquets and other ceremonies that paid tribute to a steelworker's service. ${ }^{92}$ Moreover, many locals used local union funds to build retiree recreation facilities usually within the local headquarters. ${ }^{93}$ Although formal retiree organizations such as 65 Clubs developed in the late 1940s, such formal clubs did not persist in significant numbers after the 1949 victory. Indeed, by 1958 the USWA reported that only 2 percent of local unions had retirees that formed formal retiree organizations. Noting further that "the most popular activities [for retirees] other than providing a meeting hall, are banquets, parties and picnics." 94

In the summer of 1958 after steelworkers and retirees began raising concerns over retiree specific issues such as access to adequate health care in retirement, USWA President David McDonald commissioned a study to look at the retiree situation. The union contracted with social insurance expert Murray Latimer to lead a retiree study in conjunction with Nate Cowan head of the Committee on Retired Workers. According to McDonald, the study was to, "provide us with detailed information on pensioners' health, economic, recreation, and other needs that will enable us to serve them more effectively." 95 Moreover, McDonald suggested that each local consider establishing their own Committee on Retired Workers to better address retiree issues and to provide retirees with a place to meet and socialize. ${ }^{96}$ On that point, McDonald stated,

\footnotetext{
91 Ibid.

92 "Bethlehem Pensioners Honored” Steelabor, March 1958, 12.

93 "Where Old Friends Meet: The Union Strives to Fill Needs of Retired Members" Steelabor, August $1958,4$.

${ }^{94}$ USWA Convention Proceedings, 1958, 204.

95 “From Work Into Retirement: USWA Launches Study to Solve Problems of Retirement” Steelabor, July $1958,14$. 96 Ibid.
} 
"Nothing is more important to their physical and mental well-being than the knowledge that we are still interested in them and are providing a point of contact with their union. Such simple pastimes as cards, checkers, pool, and just the opportunity to get together and reminisce, make their leisure more worthwhile." 97

The 1958 USWA convention witnessed a significant discussion of the adequacy of the union's pension and social insurance program as well as discussions about retiree issues such as access to healthcare. John Grajciar raised concerns over pension adequacy and the possible fragility of private forms of welfare security. He noted before the convention that, "even with Social Security, our pensions are not enough to live in decency."198 Moreover, he recognized the possible impact of a successful anti-union movement. He told the convention that as seen in the current right-to-work campaigns in industrial states such as Ohio and Indiana, any bargaining gains made by the union "can be taken away by reactionary state administrations." 99

Delegate Milano of local 1440, District 38 raised the issue of retiree healthcare. He praised the union for its past success in bargaining for pensions but suggested that the union had been deficient in bargaining for health security for USWA retirees. He told the convention that, "our retired members today in many instances, from what I understand, when they leave the plants and retire, have no [healthcare] conversion privileges. They have no insurance, Social Insurance or Health Insurance at all. They are cast out into society with nothing to take care of them in the event that they get sick." ${ }^{100}$ Milano argued further that at companies where the union had bargained for workers to convert their social insurance plan into an individual plan upon retirement, most retirees could not afford to do so because of rising medical costs. Milano thus

\footnotetext{
97 Ibid.

${ }^{98}$ USWA Convention Proceedings, 1958, 432.

${ }^{99}$ Ibid, 433.

${ }^{100}$ Ibid.
} 
stated, "I know members who have retired as little as two years ago and yet have had three premium increases to date." ${ }^{\prime 01}$ Lastly, Milano asked the union to think about developing its own insurance program tied to the development of its own hospitals and clinics. Stating further that under the current program, "when our members go to the hospital, every time we get an increase and new benefits are added, the doctors just raise their fees." ${ }^{102}$ President McDonald responded to Milano's request and argued that "the idea is very sound but even if the steelworkers did run the hospitals the doctors would still be able to raise their fees." Declaring further that doctors, "have got a real strong union, those boys." ${ }^{103}$

Overall, USWA leaders were not deaf to the pension, healthcare, and retiree issues raised by many of the delegates at the 1958 convention. USWA officials as far back as 1953 had been aware of many of them and had been working to study the issues in more depth and remedy problems at the bargaining table, in the halls of Congress, and in the meeting rooms and conventions of insurance providers. John Tomayko, head of the USWA pension and social insurance department, attended the 1957 Blue Cross/Blue Shield conference and stressed the union's disgust with increased costs. He informed the convention that USWA rank-and-file across the country had been voicing their concern with excessive medical costs. Noting further that "we are beginning to wonder if our premium dollar is being used to provide security for the doctor rather than security for the patient." 104 Tomyako's sharp words did not end there. $\mathrm{He}$ argued that it seemed to many in the USWA that Blue Cross \& Blue Shield was "deteriorating into a collection agency for the medical profession." ${ }^{105} \mathrm{He}$ ended his comments warning that the

\footnotetext{
101 Ibid.

102 Ibid, 434.

103 Ibid.

104 “Security For Doctors or Workers?: USWA Looks for Insurance Program which Gives Real Protection to Membership" Steelabor, May 1957, 15.

105 Ibid.
} 
USWA might begin to look for alternative social insurance coverage for its members, and he argued for the creation of a government health care program, especially to meet the needs of the elderly and indigent. ${ }^{106}$

As noted earlier, the USWA had been a consistent advocate for a government healthcare program dating back to the failed Wagner-Murray-Dingell bill. In the late 1950s, the USWA was an early supporter of the Forand Bill designed to provide medical care for the nation's elderly. Although the Forand Bill in its initial manifestation did not become law, labor's advocacy for such a bill would eventually culminate with the passage of Medicare in $1965 .{ }^{107}$ Lastly, due in great part to the concerns raised by delegates at the 1958 convention, the convention resolved to conduct a detailed and comprehensive study of its current indemnity based social insurance program and the union opened itself up to the possibility of developing a non-indemnity based social insurance program in the future. ${ }^{108}$ The convention resolution thus declared,

We believe that the present organizations underwriting the hospitalization and medical care provisions of our insurance programs are failing to meet the health care needs of our members at a reasonable cost. It has, therefore, become necessary for our Union to undertake the investigation of the possibilities of alternative arrangements. This investigation should cover all the programs established by other labor unions, and should examine the possibility of establishing our own hospitals, clinics, diagnostic centers, rest homes, rehabilitation centers, nursing homes, and the development of fully pre-paid medical care plans utilizing group practice medicine in order to provide programs of complete healthcare for the members of our Union and their families. ${ }^{109}$

Although the study began in 1958 it would not be published until 1960. In the meantime, the union, lacking the political power to enact national healthcare and fighting a well-planned

\footnotetext{
${ }^{106}$ Ibid.

${ }^{107}$ Edward D. Berkowitz, America's Welfare State: From Roosevelt to Reagan (Baltimore: The Johns Hopkins University Press, 1991) 166-167; this topic will be addressed in more depth in later chapters.

108 USWA Convention Proceedings 1958, 425.

109 Ibid.
} 
and financed conservative anti-union crusade at the state level, turned to upcoming contract negotiations in 1959 to secure a share of the fruits of steelworkers' productivity as well as make improvements to the current benefits system. Initially, the union believed that bargaining would generally procced like it had throughout the decade. However, 1959 proved to be an outlier. Indeed, the anti-union assault playing out at the state level was an early indication of what was in store for the union in 1959. Consequently, the union found itself on the defensive as the steel industry flexed its economic muscles in an effort to undo the progress that Steelworkers had made since 1936. Ultimately, the power wielded by the steel industry was met with the economic power of an industrial union with over 500,000 members that united to preserve their hard-fought gains.

\section{Steel Strike}

In April 1959 David McDonald met with steel industry negotiator R. Conrad Cooper to discuss the upcoming contract negotiations. Cooper quickly informed McDonald of the industry's position. He described to McDonald the industry's fear of inflation and the entry of foreign competition into the domestic steel market. On both points Cooper also suggested that both the Wall Street Journal and President Eisenhower were also weary of rising inflation and the threat of foreign competition. ${ }^{110}$ After explaining the industry's concerns, Cooper asked the USWA to accept a one-year extension of the current contract minus the continuance of COLA increases. Cooper argued that steelworkers' wages and benefits thus far were in line with productivity increases and that there was no need for another substantial increase in wages and benefits. In the industry's official letter to the union they argued that, "The need, therefore, is not to put more money in the pockets of the steelworkers who are now at work. The real needs are

\footnotetext{
${ }^{110}$ IEB, April 13-14, 1959, Box 46 Folder 10, 8.
} 
to avoid further employment cost increases, and thus restrain inflation and encourage continued progress essential to increasing employment opportunities for those now employed." ${ }^{111}$ Industry further argued that any union claim for wage and benefit increases based on productivity were not correct if the basis of their productivity calculation was strictly on "output per hour," which the industry argued did not account for the costs of research and development and technological investment. Noting further that, 'on the basis of so-called 'productivity,' the Steelworkers are ahead for years to come." 112

After hearing Cooper's offer, McDonald quickly and flatly rejected it. Cooper then countered McDonald's rejection with a stern warning, advising McDonald that the industry was prepared to take a more militant approach to negotiations. McDonald described the encounter to the IEB noting Cooper basically threatened the union declaring that they would fight to eliminate, "certain benefits which we now enjoy," and that the steel industry was "prepared to go to the mat with the United Steelworkers of America in these negotiations." ${ }^{113}$ McDonald advised the board that it was his gut feeling that industry was throwing all their cards into an effort to either win concessions from the steelworkers or provoke a long strike that the industry felt it could endure, with the goal of breaking the union. ${ }^{114}$ Moreover, McDonald believed the industry demands were designed to quickly scare the USWA into capitulation because the industry knew that their next quarterly earnings report would show tremendous profits, which would make arguments against raising steelworkers wages and benefits hard to justify before the bar of public

\footnotetext{
111 Ibid, 6.

112 Ibid, 7.

113 Ibid, 10.

114 Ibid, 18.
} 
opinion. ${ }^{115}$ McDonald ended his remarks noting, "Well, it looks like we are in for a fight. The only terms which they have offered us so far are unconditional surrender."116

Rather than accept concession USWA leaders believed that steelworkers were entitled to a share of increased productivity. Consequently the union's 1959 Wage Policy called for improvements across the entire spectrum of wages and benefits to include: (1) increased wages; (2) reduction of the work week; (3) improved weekend premium pay (4) increases in SUB benefits; (5) "revised, enlarged and improved insurance plans," on a non-contributory basis; (6) betterment of retiree and unemployed insurance; (7) larger pensions; (8) the acceptance of the union or agency shop were applicable (9) improved holiday and vacation pay; (10) improved grievance machinery and "local working conditions;" 117 and lastly (12) they demanded that "where existing medical organizations fail to meet the health needs of employees and their families at reasonable rates, the parties shall jointly develop a program for providing suitable alternative facilities and arrangements."118

The last demand is interesting in light of the experience of the UMWA regional hospital program, which by the late 1950 s was beginning to have financial difficulties.

However, up to the late 1950s, the USWA IEB record rarely discussed the UMWA social insurance program. Although rarely mentioned prior to the 1959 Steel Strike, the union did look at various aspects of alternative social insurance programs such as the UMWA Fund and the Kaiser Health Plans in its internal study of the USWA social insurance program initiated in 1958 and published in $1960 .^{119}$

\footnotetext{
115 Ibid, 14-15.

116 Ibid, 20.

117 Ibid, 25-26.

118 Ibid, 25.

${ }^{119}$ On the financial troubles of the UMW hospital system see Richard P. Mulcahy, Social Contract For Coal Fields: United Mine Workers Welfare \& Retirement Funds, (Knoxville: University of Tennessee Press, 2001) 54, 78; the USWA medical program study provides and overview of the UMW plan, however, never mentions if the plan was
} 
During the wage policy discussion, District Director James Griffin of Youngstown announced that he wholeheartedly concurred with the 1959 Wage Policy. He argued that the union could not concede to the industry's demands because it was wrong to do so, and moreover, the rank-and-file in his district were demanding an expansion of contract provisions in 1959. Griffin described that in his district there was "pressure from down below on the part of the officers of local unions as a result of arbitration experience, [and] as the result of wanting greater fringe benefits and wage increases." ${ }^{120}$ Griffin advised David McDonald that many locals had been writing down their demands noting,

They have these matters now in documentary form, and they have a Bill of Particulars a mile long of contract changes that they are actually interested in. So that if we have pressure from the top from industry against changes in the contract, or if they have demands that they want to make on us to get the contract watered down, there is a tremendous amount of pressure from underneath that wants improvements in the contracts and want increases in wages and fringe benefits. ${ }^{121}$

As seen in Griffin's description of the demands emanating from "down below" and the numerous demands adopted in the 1959 wage policy, the union never flinched in the face of what looked to be an industry attempt to roll back contractual gains made since 1936.

By June 4, 1959 with a strike deadline of June 30 nearing fast, talks between the USWA and the industry stagnated. David McDonald informed the IEB that the industry's chief negotiator R. Conrad Cooper would not give any consideration to the union's demands. Instead, Cooper in the last meeting stressed the industry's demand for the elimination of section 2-B of the contract that provided for negotiation over local work rules. Cooper argued that the 2-B

\footnotetext{
having financial issues. Ultimately, the study suggested the best alternative to the USWA's indemnity model of insurance was the model of healthcare provided by the Kaiser health plans. See "Special Study on the Medical Care Program for Steelworkers and Their Families," A Report by the Insurance, Pension and Unemployment Benefits Department, United Steelworkers of America, Tenth Constitutional Convention, Atlantic City, September 1960, i, 43-44, 84-93.

${ }^{120}$ IEB, April 13-14, 1959, Box 46 Folder 10, 29.

${ }^{121}$ Ibid.
} 
clause was "a roadblock to [industrial] progress." 122 Indeed, since the union's first meeting with industry back in April, steel negotiators had ramped up their concessionary demands designed to reduce the rights of steelworkers. For the union and its members, the eradication of section 2-B of the contract undermined the foundation of the union. The IEB discussed the impact of eliminating 2-B from the contract noting, "the supervisors would be free to abolish spell time, relief arrangements, lunch periods, wash-up time, shift preferences, overtime distribution systems and innumerable other conditions." Although past USWA contracts allowed management to introduce new technologies in the factories, the industry's 2-B demand would vastly expand managerial prerogative and "permit reduction of crews even where the equipment and methods are unchanged." Moreover, the statement argued that if the union capitulated to the industry's demand the union would basically "transform. . into a company union." 23 Ultimately, the industry's 2-B demand posed an existential threat to the union, which worked to rally the entire union to fight what appeared to be an industry power grab.

On June 24, just 6 days prior to the start of a national steel strike, McDonald tested the waters to see what the industry's response would be if the union was willing to accept a yearlong contract extension. Thus McDonald, confident that the industry would not accept anything but complete capitulation to its demands, approached Cooper and "orally" advised him that in the spirit of avoiding a prolonged national steel strike the union would accept extending the current contract; however, retaining the COLA provision. Moreover, McDonald asked the industry to accept stricter adherence and observance to joint company and union committee meetings

\footnotetext{
122 IEB, June 4, 1959, Box 46 Folder 12, 7.

${ }^{123}$ IEB, July 13, 1959, Box 46 Folder 16, 16.
} 
established in earlier contracts as well as the establishment of "a Joint Health Study Committee to see what we could do about some recommendations in regard to hospitals and clinics."124

After briefly discussing McDonald's offer with other industry leaders, Cooper informed McDonald that the industry would not accept. Cooper's quick dismissal of the offer enraged McDonald, feeling his offer at least deserved a day or two consideration. Furthermore, McDonald told the IEB that Cooper accused the Steelworkers of "making a power play" in these negotiations. McDonald retorted to Cooper that it wasn't the steelworkers who were making a power play arguing that it was the steel industry's,

intention this year to provoke a shutdown and to continue their tirades against the organization [USWA], slapping a three-for-one price increase and blaming everything on the union, and then through their agencies such as the NAM, scream further about the monopolistic power of unions and demanding something be done about the terrible monopolies like the United Steelworkers of America. ${ }^{125}$

McDonald's oral offer, and the subsequent exchange between Cooper and McDonald, is interesting in that it reveals the true motivations of the steel industry in 1959 . That is, the industry was looking for immediate and total capitulation to its concessionary bargaining demands or force a colossal showdown of economic power via a prolonged strike it thought it could win. McDonald's oral proposal drastically abandoned the union's initial demands and should have opened the door to a compromise. The steel industry's unwillingness to compromise thus highlights an opening salvo against the union, and more generally the postwar labor movement. Ultimately the steel industry's capitulate or strike strategy overtly marks the shattering of the glass façade that encapsulated the postwar labor-management accord.

In the days leading up to the strike deadline the USWA reached out to President Eisenhower requesting that he intervene, like Truman had in 1949, and create a fact-finding

\footnotetext{
${ }^{124}$ IEB, June 25, 1959 Box 46 Folder 13, 3, 6-7.
}

125 IEB, June 27, 1959, Box 46 Folder 14, 3. 
board to help settle the impasse. Eisenhower responded informing the union that a national emergency did not yet exist under the Taft-Hartley Act, thus he could not intervene in the dispute. The President then advised the union to continue to negotiate in the hopes of finding a compromise. ${ }^{126}$ With no federal intervention forthcoming, the union continued to negotiate. Finally, on the evening of June 28 , both sides agreed to a 14-day contract extension with the hope that a deal could be reached prior to the new strike deadline of July $15 .{ }^{127}$

The contract extension did little to advance negotiations. On July 13 McDonald discussed the possibility of a strike with the IEB. Although the rank-and-file's enthusiasm for a strike was limited prior to the industry's demand for major work rule concessions, by July the rank-and-file was prepared to strike. ${ }^{128}$ McDonald noted that the vast majority of local unions across the country had written him, "commending us on our action for extending the agreement and asking us not to extend it again." ${ }^{129}$ Noting further that of the letters he received only 2 unions, locals 1126 and 1196, wrote telegrams condemning the extension of the contract and argued McDonald was "a sell-out artist and a liar."130 Overall, McDonald believed that the rankand-file had confidence in its leadership in the event of strike.

On the eve of the July 15 strike deadline the union and industry could not reach a deal, and thus, the 1959 Steel Strike began. The strike involved over 500,000 steelworkers in what scholar Jack Metzgar described as "a battle of endurance, testing solidarities on both sides."131 the union's rank and file proved stalwart and steadfast in their fight to protect the wages, benefits, and work rules the union had won over the last twenty years. Although from 1956 to

\footnotetext{
126 Ibid, 20-22.

127 IEB, June 29, 1959, Box 46 Folder 15, 2-5.

128 Jack Metzgar, Striking Steel: Solidarity Remembered, Critical Perspectives on the Past (Philadelphia: Temple University Press, 2000), 65.

${ }^{129}$ IEB, July 13, 1959, Box 46 Folder 16, 9.

${ }^{130}$ Ibid.

${ }^{131}$ Metzgar, Striking Steel, 63.
} 
1959 the union had experienced some internal dissention in the form of the "dues protest committee," but Metzgar found that those involved with the committee gave their full support to the strike effort. ${ }^{132}$

As the strike lingered into October and as the nation's steel surpluses began to dwindle, President Eisenhower contemplated calling a national emergency and intervening with an 80-day cooling off period under the provisions of the Taft-Hartley Act. In a meeting with 5 major basic steel producers and David McDonald, Ike warned that he would seek a Taft-Hartley injunction if both sides could not come to an agreement. After the meeting with Eisenhower, Roger Blough of US Steel approached McDonald with a deal. He offered a small wage and benefit increase; however, held firm to the local work rules demand. ${ }^{133}$

The USWA IEB rejected the offer. In its response to the industry the union called the offer "totally unacceptable." 134 It argued further that the offer was deficient in three critical areas: benefits, intensified prohibitions against wildcat strikes, and the repeal of section 2-B. ${ }^{135}$ The action of the IEB had the support of the rank and file. Youngstown area district Director James Griffin explained to the board his constituent's feeling on the latest industry offer noting,

We must have talked to some 700 of the key leadership in my district and, President McDonald, I want to report to you as an actual fact, that when we got through with those meetings, you would think that we had just started the strike yesterday; the moral is just that high, and our people are determined not to take one backward step. They are behind you and they are behind the officers of this Union, and if we continue to provide the kind of leadership that you have given us through these 80 days in the future [the Taft-Hartley Cooling off Period] our people will stay with us to the last ditch. ${ }^{136}$

\footnotetext{
${ }^{132}$ Metzgar, 63.

${ }^{133}$ IEB, October 4, 1959, Box 46 Folder 19, 4-10, 15.

${ }^{134}$ Ibid, 20.

135 Ibid, 4-10, 20-24.

${ }^{136}$ Ibid, 4-10, 28-29
} 
The words of Griffin and similar words of other USWA Directors highlight that after 116-days on strike and facing an 80-day cooling off period, steelworkers were still supportive and enthused about the strike and prepared to see it through to victory. ${ }^{137}$

By mid-October the industry continued to reject union demands and introduced another concessionary demand in the area of social insurance. The steel industry thus proposed that the union accept a weaker "major medical" health plan, which would place more of the insurance cost burden on the individual worker. For, instance, John Tomayko, head of the USWA's Pension and Social Insurance Department advised the IEB that the industry's major medical proposal "incorporated a fifty-dollar deductible provision plus a further proviso to the effect that the plan would pay only eighty percent of the cost." ${ }^{138}$ Although the union rejected this demand outright, employers throughout the 1960s, and up to the present day, have pushed inferior major medical insurance coverage on workers to replace contributory and non-contributory health plans such that the USWA won in 1949 [contributory] and 1959 [non-contributory]. ${ }^{139}$

At the October 19 IEB, McDonald informed the board that President Eisenhower on October 20 would seek a Taft-Hartley injunction against the strike, thus initiating an 80-day cooling off period reopening the steel mills and forcing strikers back to work. To possibly avoid the injunction McDonald suggested that the union agree to arbitration to settle the dispute. Directors Germano and Molony agreed, however, many other directors argued against the action. ${ }^{140}$ Some directors pointed to a recent dispute in the glass industry which went to arbitration and the arbiters handed down an unfavorable outcome to the glass workers. Other

\footnotetext{
${ }^{137}$ James Griffin's description of Youngstown workers corresponds to what Jack Metzgar found in his study of Johnstown, PA steelworkers during the 1959 Steel Strike see Metzgar, Striking Steel, 72, 82.

138 IEB, October 17, 1959, Box 46 Folder 22, 1-2.

${ }^{139}$ Klein, For All These Rights, 241-243.

${ }^{140}$ IEB, October 19, 1959, Box 46 Folder 23, 1-4.
} 
directors argued that if the union accepted arbitration many members "would be "sickened" and "feel that the union had let them down." 141 In the end the voices against seeking arbitration won the day. McDonald then changed his views to coincide with those against arbitration.

McDonald argued that in leu of arbitration the union accept the injunction while at the same time "beat the publicity drums and hope that the President's Board of inquiry will keep at work and be instrumental in bringing about agreement." 142 The board gave its unanimous approval to this course of action. ${ }^{143}$

Immediately after Eisenhower won his Taft-Hartley injunction the steelworkers challenged its legality. However, the union ultimately lost its case before the Supreme Court. ${ }^{144}$ Eisenhower's Taft-Hartley injunction stoked the anger of many striking steelworkers. This anger was literally worn on the sleeves of workers returning to work in the form of arm bands that read "Ike's slaves."145 Moreover, steelworkers returned to obsequious and unfaithful company patronage in a company effort to win over the hearts and minds of the workers during the 80-day cooling off period. Despite these duplicitous overtures, polls showed that the majority of steelworkers would vote against the last industry offer if a Taft-Hartley vote was taken. ${ }^{146}$ As the cool-off period set in, some steel companies such as Kaiser Steel began to break ranks with the other steel producers. In essence, Kaiser settled with the steelworkers paving the way for future settlements. Kaiser agreed to a wage increase of $22 \frac{1}{2}$ cents an hour over 20 months and dropped its demand to eliminate section 2-B of the contract. ${ }^{147}$ The USWA IEB viewed the Kaiser deal as a positive breakthrough noting, "these agreements [Kaiser and a few

\footnotetext{
${ }^{141}$ Ibid, 2-3.

142 Ibid, 6.

143 Ibid.

${ }^{144}$ Metzgar, Striking Steel, 73-74.

145 Metzgar, 79; IEB, November 12, 1959, Box 46 Folder 25, 26.

146 Metzgar, 77-79.

${ }^{147}$ Metzgar, 76-77.
} 
other small firms] demonstrates beyond doubt that reasonable men on both sides who are willing to consider the welfare of the workers, the companies and the public can readily find a formula to resolve their differences." 148 Also, by mid-November McDonald had been working on a settlement "with people whose names cannot be revealed" and that prior to the injunction he had almost secured a strike ending deal. ${ }^{149}$ Noting further that "General Motors was involved and a lot of people were involved and it was damn near there." ${ }^{150}$ He ended his remarks suggesting that a breakthrough might be had in the near future. ${ }^{151}$ McDonald then argued that the union send out a public statement that did not directly attack President Eisenhower, but instead, lay the blame for the injunction more ambiguously on the "government." This approach received much push back from many district directors who had large constituencies of rank and file workers who were enraged and disgusted with Eisenhower's Taft-Hartley intervention. ${ }^{152}$

McDonald countered the director's anger over the ambiguous public statement declaring "whenever I say I have a reason for writing the resolution this way, believe me, I have a sound reason for it." 153 He told the directors that if they wanted to criticize Eisenhower on an individual basis they could but due to the ongoing talks between the USWA and the administration, McDonald believed it was in the best interest of the union to not directly criticize the President in the union's public statement. Many directors voiced their concern with this approach. Director James Robb argued that many other labor unions were openly criticizing the President and their anger towards an anti-labor Congress, which had recently passed the antilabor Landrum Griffin Act, which sought to punish and demonize the entire US labor movement

\footnotetext{
${ }^{148}$ IEB, November 12, 1959, Box 46 Folder 25, 10.

149 Ibid, 15-18.

${ }^{150}$ Ibid, 18.

151 Ibid, 17.

152 Ibid, 18-20.

153 Ibid, 20.
} 
for the unsavory actions of a few corrupted labor leaders such as Jimmy Hoffa of the Teamsters Union. ${ }^{154}$ Director Martin Walsh argued that it would look bad to the membership if the union and its president didn't level some blame directly in Ike. Lastly, Director A. F. Kojetinsky believed that such as strategy might dampen rank-and-file moral declaring that, "this thing is going to be won on the picket line. It can't be won anywhere else," thus inferring that the strike would not be won in closed door sessions with the President. ${ }^{155}$

Although the IEB record highlights some significant disagreement over the issue, the disagreement did not mark a lack of confidence in McDonald. This IEB exchange does highlight that Directors were more open and aggressive in airing their concerns and complaints to McDonald compared to his predecessor Philp Murray. Generally speaking when Murray was president he spoke to the directors and the directors fell in line. However, under McDonald's leadership, particularly in the latter portion of the 1950s, exchanges like the one just described became more frequent. Again, the disagreement over this issue did not mean the IEB had lost confidence in their leader. Indeed prior to voting on the resolution Director Germano interjected, declaring to McDonald, "You know there is greater admiration for you today, Dave, than there has ever been in this organization and, damn it, let's keep it that way. I am telling you that as your friend, as your friend I am telling you," suggesting that McDonald directly criticize the President. ${ }^{156}$ Ultimately, McDonald's version of the public statement resolution passed, however, not unanimously. ${ }^{157}$

As the end of the cooling off period loomed on the horizon and as President Eisenhower began lobbying Congress to pass a "compulsory arbitration law," the union, backed by some key

\footnotetext{
${ }^{154}$ Ibid, 22-23; For more on the Landrum-Griffin Act see Fones-Wolf, Selling Free-Enterprise, 274-278.

${ }^{155}$ IEB, November 12, 1959, Box 46 Folder 25, 26-27.

${ }^{156}$ Ibid, 28.

${ }^{157}$ Ibid, 31 .
} 
administration officials, such as Secretary of Labor George Mitchel and Vice President Richard Nixon, were ultimately able to pressure the steel industry into accepting an extremely favorable contact for the USWA. ${ }^{158}$ The deal was struck on January 5, 1960. At the January 5 IEB McDonald took time to more fully explain his position against criticizing Eisenhower. $\mathrm{He}$ stressed that up until Nov 12 he had been in direct talks with Eisenhower and he feared that a union public statement directly criticizing the President would have undermined those negotiations. McDonald stated that, "I spent an hour and fifty minutes one day with the President of the United States explaining the situation." Noting further, "That was one of the reasons, Jimmy [Director Jim Robb], why I wouldn't accept the amendment to the policy statement." McDonald argued that up until his talks with the president, Ike "had been brainwashed pretty badly, but I succeeded in unbrainwashing him, I think." ${ }^{59}$ McDonald felt that building an amiable relationship with the President in conjunction with unwavering rankand-file solidarity both worked to win the day. Noting further that "you use every device you possibly can in order to get a labor agreement, and we used everyone we possibly could,- - and we got a labor agreement." ${ }^{\prime 160}$ Indeed, considering the steel industry's goal of forcing the union into concessionary bargaining, the union, relying on the unwavering solidarity of over 500,000 members, beat back the employer assault and actually managed to win significant wage and benefit gains, while preserving section 2-B of the contract.

In the end, the steelworkers secured a wage increase of 7 cents an hour to be increased Dec 1, 1960 and again October 1, 1961. The union retained COLA although with a new provision that the 7-cent an hour contribution would fluctuate based off of any cost increases in

\footnotetext{
${ }^{158}$ Metzgar, 79-82; IEB, January 5, 1960, Box 46 Folder 26, 7-8.

${ }^{159}$ Ibid, 5 .

${ }^{160}$ Ibid, 8 .
} 
the insurance program. In essence, the 7-cent payment could decrease if health care cost increased. ${ }^{161}$ The union also won the "agency shop...applied where it is lawful under the laws of the state."162 The contract established a human relations committee to "study guides for determination of equitable wage and benefit adjustments."163 Moreover the new contract allowed for SUB payment increases and the establishment of a Joint Committee to study the idea of Philip Murray's Industry Council Plan proposed during the World War II era. The industry council plan had been a longtime goal of Murray, which was steeped in the social catholic tradition and conception of a well-functioning society. Upon announcing the establishment of the committee to study the Industry Council Plan, McDonald noted that such a committee "will make a lot of our theological friends happy."164

Where the union made the most significant achievements was in retaining the 2-B clause of the contract and in advancing its pension and social insurance program. McDonald argued that protecting 2-B was the greatest success of the strike, which highlighted the strength and solidarity of the union in standing firm against an all-out employer assault against the rights of workers. ${ }^{165}$ In addition to holding the line on work rules, the union won a non-contributory social insurance program, which had been the union's goal since the historic 1949 steel strike. Now the steel industry would pick up the entire cost of the social insurance program. Moreover, noncontributory social insurance also acted to advance wages taking money that used to be paid by the worker for insurance, and instead put that money directly into the wallets of steelworkers. ${ }^{166}$ The contract also created a "special retirement payment equal to 13 weeks' pay"

\footnotetext{
161 Ibid, 25-26.

162 Ibid, 28.

163 Ibid, 33-34.

164 Ibid, 9.

165 Ibid, 14.

166 Ibid, 19.
} 
plus any unused vacation time. On average this new provision would amount to a bonus payment upon retirement of approximately $\$ 1500 .{ }^{167}$ The union was quick to point out to steelworkers that this new provision alone made "up for all the wages lost during" the 116-day strike. ${ }^{168}$ Other provisions advanced the financial wellbeing of retirees. They increased pension payments by 5 dollars a month, life insurance by $\$ 500$, and added an extra $\$ 11$ dollars a month to the sickness and disability plan. ${ }^{169}$ Workers also received a pension protection provision for up to a 2-year break in service. Furthermore, in order to open opportunities of advancement for younger steelworkers, and better the quality of retirement for retirees, the union won full retirement benefits at age 60 with at least 15 years of service. In addition, the union won pension protection against layoff, sickness, or shut down for those retiring after January 1, 1960, and who were at least 55 years old and had 20 years of service. ${ }^{170}$

On the issue of younger versus older workers, USWA attorney Arthur Goldberg noted that the deal will hopefully "encourage some of the older fellows to retire at age 60. "171 Goldberg also argued that the USWA was unique in its relationship to its retirees. He stated that some unions to include the UAW, "have made agreements relinquishing their right to bargain for" retirees. The USWA's ability to bargain for raises in retiree pensions "shows that the union hasn't forgotten about them." 172 Despite this last provision the fact remained that retirees were not dues paying members of the union, and as the steel industry began to constrict in the late 1970s, this fundamental fact would eventually plague the relationship between the union and USWA retirees.

\footnotetext{
${ }^{167}$ Ibid, 12-13.

168 Ibid, 13.

169 Ibid, 19.

170 Ibid, 21-22.

171 Ibid, 23.

172 Ibid, 24.
} 


\section{Conclusion}

The solidarity and determination of steelworkers to hold the line against what most viewed as an employer assault was nothing short of monumental. The steel industry had gambled that postwar era steelworkers would crumble under the economic pressure of a long strike. Their prediction failed to manifest over the course of 116-days. On why steelworkers weathered the storm Jack Metzgar writes, "On the other side of desperation is anger, vengefulness, determination, even a heighted sense of humor-and a growing sense of solidarity among those who are being bombed by the people they cannot see." ${ }^{173}$ Noting further that 'Nearly four months without paychecks and then two months of 'buttering up' [by employers] had not weakened the steelworkers' commitment to their union and their work rules."174

The 1959 steel strike and the associated gains in the pension and social insurance program marked a capstone to the USWA's decade-long fight to achieve the long-term welfare security goals it first pursued in its 1944 wage case and partially won in the 1949 steel strike. For the most part, the union achieved those goals by bringing unprecedented private welfare security to its members. They did this through the collective bargaining process and the purchase of indemnity insurance. From the beginning in 1949, the union believed that such indemnity forms of insurance coverage would be adequate to meet the needs of its membership while at the same time the union called on the nation's lawmakers to expand public social welfare to provide extra security for its members as well as to provide security for those American's absent strong union protection. However, what the union could not foresee in 1949, was the stark reality that indemnity forms of private social insurance had limited mechanisms for cost control, and with the help of fee for service medical practitioners and hospitals, medical cost

\footnotetext{
${ }^{173}$ Metzgar, Striking Steel, 72.

174 Metzgar, 82.
} 
quickly rose throughout the 1950s weakening the program for active members and the rapidly expanding retiree population. 


\section{Chapter 7: Conclusion: The End of the Road}

Upon completion of the 1958 USWA convention, the USWA Pension and Social Insurance Department contracted with Dr. I.S. Faulk and Joseph Senturia, an employee of Murray Latimer's consulting firm, to conduct an in-depth study of the current social insurance program. The study focused on two overarching criteria. First, it looked for ways the current indemnity based social insurance program could be expanded and improved. Second, it looked for alternative non-indemnity social insurance coverage that the union could bargain for in the future. The report also stressed that although the union was primarily focused on fixing the deficiencies within its contracted security programs, the union was "also deeply interested in the broader problems of medical care in this country, affecting not only Steelworkers but the community and the nation as a whole."1

The study first identified four specific weaknesses in the current social insurance system, starting with the system's "lack of full service benefits." In essence, from 1949 up to the publishing of this report, the union had always pursued the goal of achieving a social insurance program that adequately covered the hospital and surgical needs of steelworkers and paid for the entire cost of treatment. The union defined such a program as "good insurance." According to the report, the union's hospitalization program was the only program that came close to meeting the union's definition of good insurance. For example, under the Blue Cross hospitalization plan, 96 percent of a steelworker's hospitalization costs were covered, although some of the finer perks and amenities such as private rooms and television sets were not covered. However, the report went on to note that the union's Blue Shield major medical plan did not fit the union's

\footnotetext{
1 "Special Study on the Medical Care Program for Steelworkers and Their Families," A Report by the Insurance, Pension and Unemployment Benefits Department, United Steelworkers of America, Tenth Constitutional Convention, Atlantic City, September 1960, 7-8. (Hereafter "Medical Care Report, 1960") ii.
} 
definition of good insurance. Unlike Blue Cross, Blue Shield plan covered on average only 84 percent of a steelworker's surgical and maternity costs. ${ }^{2}$ The report thus declared, "the doctor's charges on the average are nearly 20 percent higher than the insurance fee allowances. And for those patients with higher charges, the average charge is more than 50 percent higher than the insurance fee." ${ }^{3}$

The only state where surgical prices were not excessive was Pennsylvania. Throughout the mid-to-late 1950s, the union actively lobbied the state's physicians to agree to accept the indemnity fee schedule of insurance as paid in full for individual steelworkers who made less than $\$ 4000$ a year and steelworkers with families that made less than $\$ 6000$ a year. ${ }^{4}$ The agreement with Pennsylvania doctors was indeed a breakthrough that brought the USWA's indemnity based program of insurance closer to its definition of good insurance, as the agreement greatly limited out of pocket costs in Pennsylvania. Unfortunately, the same goodwill displayed by physicians in Pennsylvania did not reverberate throughout the other states of the union, as other physicians did not accept the Pennsylvania agreement. ${ }^{5}$ Elaborating on the union's inability to secure agreement in other states, the 1958 USWA convention proceedings noted that, "The medical societies have shown no disposition to accept such an arrangement. It is extremely doubtful that so long as physicians are reimbursed on a fee-for-service basis they will voluntarily agree to accept any particular fee as full payment for their services." ${ }^{\circ}$

Another deficiency noted in the report dealt with the lack of comprehensive benefits coverage despite the myriad enhancements the union made through bargaining over the course of

\footnotetext{
${ }^{2}$ Ibid, 5.

${ }^{3}$ Ibid.

${ }^{4}$ Ibid.

${ }^{5}$ Ibid.

${ }^{6}$ USWA Convention Proceedings 1958, 161.
} 
the 1950s. On that point, the report stated, "we are far from having this full range of coordinated services and it is hard to see how we can get it under the present pattern of purchased insurance." $"$ The report also addressed the issue of social insurance effectiveness. It noted that, as of 1960, the USWA healthcare program covered 41 percent of "total family health costs." For instance, the program did not yet cover healthcare needs such as vision, and for those areas of healthcare that were covered, doctors frequently charged more than what the insurance paid, leaving the steelworkers to pick up the remaining costs from their current wages. The 41 percent figure was deficient when compared to non-indemnity base social insurance plans, which at that time covered 55 percent of total healthcare costs. ${ }^{8}$ The inability of the union to achieve 100 percent cost coverage through their indemnity social insurance plan highlighted the fact that the USWA had yet to achieve its goal of comprehensive prepaid social insurance for its members.

Lastly, the report focused in on the lack of cost controls associated with indemnity-based insurance. Since the start of the 1949 pension and social insurance plan, medical costs in the US had risen faster than inflation. ${ }^{9}$ In fact, the report concluded that over the course of the $1950 \mathrm{~s}$ medical costs had doubled, which was significantly more than the inflation on general goods and services over the same time period. ${ }^{10}$ The report argued that the excessive costs associated with medical care was a product of doctors and hospitals charging above and beyond the insurance indemnity schedule as well as ordering unnecessary medical procedures and hospital admittances. ${ }^{11}$ The report found that pre-paid group practice medical plans had lower numbers of hospital admittances and days spent in the hospital than non-group practice plans. From July

\footnotetext{
${ }^{7}$ Medical Care Report, 1960, 7.

${ }^{8}$ Ibid.

${ }^{9}$ Ibid, 6.

${ }^{10}$ Ibid, 8.

${ }^{11}$ Ibid, 6.
} 
1, 1957 to June 30, 1958, the Kaiser Foundation Health Plans (KFHP), a prepaid group practice plan, had 90 inpatient hospital admissions per 1000 insured persons and 570 hospital days per 1000 insured persons. ${ }^{12}$ In contrast, the USWA Blue Cross plan had 135 inpatient hospital admissions per 1000 and 1032 hospital days per 1000 insured persons. The rates for hospital surgical care were also higher for Blue Cross as compared to KFHP. ${ }^{13}$ The report concluded that for the same care and quality, prepaid programs such as KFHP were more economical than the union's current plan built around the Blue Cross/ Blue Shield model. Moreover, it found that prepaid group practice plans, which used salaried physicians, rather than fee-for-service physicians, were cheaper and less prone to excessive charges and unnecessary medical procedures and hospital admittances. ${ }^{14}$ In terms of rising medical costs, the report argued that the increased costs associated with their current insurance coverage damaged the union's ability to raise wages and improve other member benefits in collective bargaining. ${ }^{15}$

The report ended with a series of conclusions. First, it noted that the current indemnitybased insurance system, when compared to health care coverage around the country, was still good; however, the coverage was not as yet comprehensive or fully prepaid. Second, the report concluded that the union could not buy its way out of its current healthcare problems. Third, although there were deficiencies with the current program, the report suggested the union take a near and a long-term approach. In the near term, it suggested the union continue as it had and work to improve the current system where it could through bargaining. Over the long term, however, the report stated that the union look to develop a social insurance program tied to prepaid group practice medical coverage like KFHP declaring that such plans, "deserve our most

\footnotetext{
${ }^{12}$ Ibid.

${ }^{13}$ Ibid.

${ }^{14}$ Ibid.

${ }^{15} \mathrm{Ibid}, 8$.
} 
serious consideration as we design our program for the years ahead." ${ }^{16}$ Finally, in order to achieve a prepaid group practice system, the report stated that the union should attempt to secure such a system through collective bargaining and cooperation with employers and health organizations. However, if such cooperation was not forthcoming, the union should consider creating such a program on its own. ${ }^{17}$ The report thus found that the current shortfalls of the USWA social insurance program were the result of "the policies, attitudes and self-interests of insurance carriers, physicians and hospitals." Noting further,

We have to ask ourselves: Can we reasonably hope for real solutions to these problems in the near future within the framework of the present standard insurance programs offered by the Blue Plans and the commercial insurance companies? Or have we come to the end of a road, and consequently must seek solutions and further improvements through a different kind of prepayment program to provide our health benefits? ${ }^{18}$

The 1960 report revealed more fully the insufficiency of the private indemnity model of insurance and made the USWA question the security system it had created over the course of 1941 to 1960 . Indeed, the United Steelworkers of America was arguably the largest and most powerful industrial union in US history. The union throughout the twentieth century had a tremendous impact on the lives of its members, and the larger American working class. Its leader Philip Murray was not only the president of the USWA but also the precedent of the CIO and viewed the Steelworkers' union as the exemplar by which other unions could emulate. His leadership from 1936 to his death in November 1952, witnessed the most significant improvement in the lives of steelworkers and many others within the larger industrial working class. From wages to the shop floor to the long-term welfare security of steelworkers, Murray, and to a degree his successor David McDonald, oversaw the meteoric ascendency of the USWA.

\footnotetext{
${ }^{16}$ Ibid, 3.

${ }^{17}$ Ibid, 10-11.

${ }^{18}$ Ibid, 7-8.
} 
Much has been written about industrial unionism, the USWA, and the influence and impact that industrial union leaders have had on the history of the Great Depression, World War II, and the postwar era. Undoubtedly, as seen in this study industrial union leaders had a significant role in the history of the labor movement and more specifically the development of America's flawed public/private welfare state. Moreover, other large institutions such as the forprofit insurance industry and political institutions such as the federal congress have also played a significant role in the creation of the public/private welfare state. However, the history of this development should not begin and end at the top. Indeed, a fuller more nuanced picture of the development of the public/private welfare state has to begin to account for the role the rank-andfile union member had on the decisions made by their leaders.

This study of the USWA's quest to provide long-term welfare security to its members from WWII to 1960 tries to do that, and it argues that USWA leaders, in particular Philip Murray and David McDonald, were intimately aware of the wants, needs, and desires of rank-and-file steelworkers, and were responsive to their welfare security demands. After failing to pass the Wagner-Murray-Dingell bill during WWII and given the encumbrances of the "Little Steel" formula's wartime wage freeze, the USWA first turned to their 1944 wage case to try and win an employer provided pension and social insurance plan. Although winning on several demands of their 24-point wage program, the NWLB failed to mandate that steel employers institute a pension and social insurance plan. Moreover, as the war came to a halt, the steel industry began arbitrarily force retiring steelworkers at age 65 , eliminating their main source of income with no long-term security except for a less than subsistence level social security old age pension. Consequently, the postwar retiree crises mobilized many rank-and-file steelworkers to push their leaders to bargain for better forms of welfare security with their employers to ease the burden of 
the force retired and to create a system that would provide for their eventual long-term security needs. Moreover, rank-and-file steelworkers had a long history with steel industry welfare capitalism, and many steelworkers prior to 1949 had used their own wages to pay for weak forms of private social insurance. The record thus highlights that rank-and-file steelworkers pushed their leaders to use the union's economic power to eradicate the arbitral paternalistic nature of welfare capitalism, and instead, bargain for a system of adequate benefits, that was paid entirely by the employer and that also secured a legitimate voice over the administration of insurance plans. What began as a call to help the forced retired, eventually culminated in the USWA's victory in the 1949 steel strike and the subsequent creation of a pension and social insurance system.

Throughout the period of 1946 to 1949, as seen in the union's International Executive Board records, USWA Convention proceedings and the union's journal of record, Steelabor, union leaders such as Philip Murray were cognizant of the retiree issue and responsive to rankand-file demands. Although, the union was willing to pursue private welfare security options, union leaders, never abandoned their desire to see the expansion of the public welfare state to include a national healthcare system. However, the political realities of the day, combined with rank-and-file demands stemming from the retiree crises as well as the desire for long-term security on the part of active steelworkers, pushed union leaders toward bargaining for private security. Moreover, the USWA, being one of the largest, and quite possibly the most influential industrial labor union of the Depression and postwar eras, became a trailblazer in bargaining for increased wages and benefits in the postwar era. The union's breakthrough victory in 1949 opened the door for other industrial unions to follow. Indeed, as highlighted earlier, Walter Reuther praised the USWA's 1949 effort to win pensions and social insurance at the bargaining 
table, and he called the 1949 Fact-Finding Board report another "Magna Carta" of labor, sharing a kinship to labor's first "Magna Carta," the 1935 Wagner Act. Philip Murray too, understood the long-term ramifications of the 1949 victory as he saw the USWA as a model union within the CIO, and he believed the pattern set by the union in 1949 would be replicated to various degrees throughout industrial workplaces across the country. Although the pensions and social insurance won by the union in 1949 vastly bettered the lives of countless steelworkers, the victory also planted the seeds that would eventually sprout into the country's very deficient public-private welfare state model of security, the ramification of which we are living with today.

Although victorious in establishing an employer provided pension and social insurance system in 1949 the program was deficient on a number of levels. Thus, throughout the 1950s the union used its bargaining power to attempt to expand and improve the program. As in the immediate postwar period, the political environment of the 1950s was not conducive to passing national healthcare or other progressive legislative reforms. In addition, the American labor movement came under a concerted anti-union assault, first with the passage of the Taft-Hartley law, and then throughout the 1950 s with a state level right to work campaign, the McClellan Hearings, and the Landrum-Griffith bill. More specifically, in 1959 the steel industry demanded concessions from the steelworkers in an attempt to roll back the gains the USWA had made since the Depression. Despite a poor political climate and the reemergence of class warfare, now more covert and behind the scenes, the USWA relied heavily on its economic power to secure better wages, working conditions, and benefits at the bargaining table as well as to protect the significant gains it had already made.

As the deficiencies of the 1949 pension and social insurance plan materialized, rank and file workers, via forums such as Operation Sound Off in 1953 as well as USWA conventions, 
pushed their leadership for improvements to the pension and social insurance program. From 1949 to 1959 , the union made dramatic improvements to the pension and social insurance system. The year 1959 marked the pinnacle of the USWA's effort to bargain for security as the union relied heavily on its size, strength, and rank-and-file solidarity to defeat a steel industry attempt to win concessions. Rather than capitulate, steelworkers over the course of a 116-day strike not only prevented concession, they won significant improvements to the contract, especially with regard to the pension and social insurance system. 1959 thus marked a high point in the postwar fight for security as the union finally secured its 1949 demand for a "noncontributory" social insurance plan.

Despite the current deficiencies associated with the development of the postwar publicprivate welfare state, the era from World War II to 1960 did witnessed unprecedented gains in long-term welfare security for USWA members and many other industrial workers, especially when juxtaposed to the lives of steelworkers prior to the birth of the union. Indeed, by 1960 the union recognized how much it had achieved, but at the same time had to grapple with the fact that the indemnity insurance model was flawed and that a new approach to social insurance based on a prepaid healthcare model such as the Kaiser Foundation Health Plan was needed. The process of crafting a new social insurance plan would be long and difficult process. Added to the difficulty was the fact that the current indemnity-based plan was well entrenched by 1960 . With employers intensifying their attacks on labor as seen in the 1959 steel strike, and with the decline of New Deal liberalism and the rise of neoliberal global corporatism looming on the horizon, the time for complete change had past and the time for holding on was just beginning. 


\section{BIBLIOGRAPHY}

\section{Primary Sources}

\section{Manuscripts and Special Collections:}

Historical Collections and Labor Archives, Special Collections Library, Pennsylvania State University.

United Steelworkers of America, International Executive Board Records, 1940-1973

United Steelworkers of America, President's Office Records, 1916-1980

United Steelworkers of America, Vice President's Office Records, 1937-1969

United Steelworkers of America, Research Department Records, 1921-1981

United Steelworkers of America, Communications Department records, 1919-2009 (bulk 1937-2009)

David J. McDonald Papers, 1931-1970

SWOC and USWA Convention Proceedings, 1937-1958

Franklin Delano Roosevelt Presidential Library and Museum

Copy of the Atlantic Charter (5-page draft release with FDR's handwritten annotations)

found at Franklin Delano Roosevelt Presidential Library and Museum website,

http://www.fdrlibrary.marist.edu/aboutfdr/atlanticcharter.html on April 9, 2016.

The American Presidency Project

Harry S. Truman: "Radio Address to the American People on Wages and Prices in the

Reconversion Period.," October 30, 1945. Online by Gerhard Peters and John T.

Woolley, The American Presidency Project.

http://www.presidency.ucsb.edu/ws/?pid=12303.

Harry S. Truman: "Executive Order 9599_-Providing for Assistance to Expanded Production and Continued Stabilization of the National Economy During the Transition from War to Peace, and for the Orderly Modification of Wartime Controls Over Prices, Wages, Materials and Facilities," August 18, 1945. Online by Gerhard Peters and John T. Woolley, The American Presidency Project. http://www.presidency.ucsb.edu/ws/?pid=77920.

Harry S. Truman: "Address at the Opening Session of the Labor- Management Conference.," November 5, 1945. Online by Gerhard Peters and John T. Woolley, The American Presidency Project. http://www.presidency.ucsb.edu/ws/?pid=12300.

Harry S. Truman: "Executive Order 9697-Providing for the Continued Stabilization of the National Economy During the Transition from War to Peace," February 14, 1946. Online by Gerhard Peters and John T. Woolley, The American Presidency Project. http://www.presidency.ucsb.edu/ws/?pid=77993. 


\section{Federal Records:}

Executive Order 9017 Dated January 12, 1942: Establishment of the National War Labor Board, Section B-2 (also B-3 thru B-5), Vol. 2, The Termination Report of the National War Labor Board: Industrial Disputes and Wage Stabilization, January 12, 1942 to December 31, 1945.

Emergency Price Control Act of 1942 [Public Law 421 - 7 $7^{\text {th }}$ Congress Chapter 26-2D Session H. R. 5990], January 30, 1942, Section B-6, Vol. 2, The Termination Report of the National War Labor Board: Industrial Disputes and Wage Stabilization, January 12, 1942 to December 31, 1945.

National War Labor Board, Case Nos. 30, 31, 34, 35 In the Matter of Bethlehem Steel Corporation, Republic Steel Corporation, Youngstown Sheet \& Tube Co., Inland Steel Co. and the United Steelworkers of America, C.I. O., formerly known as Steelworkers Organizing Committee, C.I.O., July 16, 1942, Section G-2, Vol. 2, The Termination Report of the National War Labor Board: Industrial Disputes and Wage Stabilization, January 12, 1942 to December 31, 1945.

United States, Report to the President of the United States on the Labor Dispute in the Basic Steel Industry (Washington: U.S. Govt. Print. Off, 1949).

The Nation's Health, Discussion at the National Health Conference, July 18, 19, 20 , 1938, Washington, D.C., called by the Interdepartmental Committee to Coordinate Health and Welfare Activities, to consider a National Health Program proposed in the Report of the Technical Committee on Medical Care.

Revenue Revision of 1943, Hearings before the Committee on Ways and Means House of Representatives, Seventy-Eighth Congress First Session on Revenue Revision of 1943, Revised October 4, 5, 6, 7, 8, 11, 12, 13, 14, 15, 16, 18, 19, and 20, 1943.

National War Labor Board; In the Matter of: Carnegie-Illinois Steel Corporation et al., and the United Steelworkers of America, CIO, December 27, 1943 case No. 13-350-D in National War Labor Board, Case No. 111-6230-D-14-1 et al., In Re: United Steelworkers of America and the United States Steel Corporation, et al., Brief Submitted by the United Steelworkers of America to Panel of National War Labor Board.

United States, Report to the President of the United States on the Labor Dispute in the Basic Steel Industry (Washington: U.S. Govt. Print. Off, 1949)

\section{Newspapers and Periodicals:}

The New York Times

The Youngstown Vindicator

Steel Labor

The Iron Age

Everybody's Magazine 


\section{Secondary Sources}

Atleson, James B. Labor and the Wartime State: Labor Relations and Law During World War II. Urbana: University of Illinois Press, 1998.

Bell, Thomas and David P. Demarest. Out of This Furnace: A Novel of Immigrant Labor in America. Pittsburgh: University of Pittsburgh Press, 1976.

Bellow, Gary and Martha Minow eds. Law Stories. Anne Arbor: University of Michigan Press, 1998.

Bensman, David. Rusted Dreams: Hard Times in a Steel Community. New York: McGraw-Hill, 1987.

Berkowitz Edward D. America's Welfare State: From Roosevelt to Reagan. Baltimore: Johns Hopkins University Press, 1991.

Biles, Roger. A New Deal for the American People. DeKalb: Northern Illinois University Press, 1991.

Bluestone, Barry, and Bennett Harrison. The Deindustrialization of America: Plant Closings, Community Abandonment, and the Dismantling of Basic Industry. New York: Basic Books, 1982.

Boyle, Kevin. The UAW and the Heyday of American Liberalism, 1945-1968. Ithaca: Cornell University Press, 1995.

Brands, H. W. The Strange Death of American Liberalism. New Haven: Yale University Press, 2001.

Brandes, Stuart D. American Welfare Capitalism, 1880-1940. Chicago: University of Chicago Press, 1976.

Brinkley, Alan. The End of Reform: New Deal Liberalism in Recession and War. New York: Alfred A. Knopf, 1995.

Brody, David. Labor in Crisis: The Steel Strike of 1919. Philadelphia: Lippincott, 1965.

---------. Steelworkers in America: The Nonunion Era. Cambridge: Harvard University Press, 1960.

-----------. Workers in Industrial America: Essays on the Twentieth Century Struggle. New York: Oxford University Press, 1980.

Bronder, Saul. Social Justice and Church Authority: The Public Life of Archbishop Robert E. Lucey. Philadelphia: Temple University Press, 1982. 
Brownlee, W. Elliot eds. Funding the Modern American State, 1941-1995: The Rise and Fall of the Era of Easy Finance. New York: Cambridge University Press, 1996.

Bruno, Robert. Justified by Work: Identity and the Meaning of Faith in Chicago's Working-Class Churches. Columbus: Ohio State University Press, 2008.

Clark, Paul F, Peter Gottlieb, Donald Kennedy, and Pennsylvania State University. Dept. of Labor Studies. "Forging a Union of Steel: Philip Murray, SWOC, and the United Steelworkers." Ithaca: ILR Press, 1987.

Cohen, Lizabeth. Making a New Deal: Industrial Workers in Chicago, 1919-1939. New York: Cambridge University Press, 1990.

-----------. A Consumers' Republic: the Politics of Mass Consumption in Postwar America. New York: Knopf, 2003.

Collins, Robert M. More: The Politics of Economic Growth in Postwar America. New York: Oxford University Press, 2000.

----------. "Positive Business Responses to the New Deal: The Roots of the Committee for Economic Development, 1933-1942." The Business History Review 52, no. 3 (October 1, 1978): 369-91.

Conkin, Paul K. The New Deal. New York: Crowell, 1967.

Cowie, Jefferson. Capital Moves: RCA's 70-Year Quest for Cheap Labor. New York: The New Press, 2001.

Cowie, Jefferson and Joseph Heathcott. Beyond the Ruins: The Meanings of Deindustrialization. Ithaca: ILR Press, 2003.

Derickson, Alan. Health Security for All: Dreams of Universal Health Care in America. Baltimore: The Johns Hopkins University Press, 2005

Derthick, Martha. Policymaking for Social Security. Washington: The Brookings Institution, 1979.

Doherty, Thomas Patrick. Cold War, Cool Medium: Television, McCarthyism, and American Culture. New York: Columbia University Press, 2003.

Dubofsky, Melvyn, and Warren Van Tine. John L. Lewis: A Biography. New York: Quadrangle, 1977.

Dudziak, Mary L. Cold War Civil Rights: Race and the Image of American Democracy. Princeton: Princeton University Press, 2000. 
Fones-Wolf, Elizabeth A. Selling Free Enterprise: The Business Assault on Labor and Liberalism, 1945-60. Urbana: University of Illinois Press, 1994.

Fraser, Steve, and Gary Gerstle. The Rise and Fall of the New Deal Order, 1930-1980. Princeton: Princeton University Press, 1989.

Freeman, Joshua B. American Empire: The Rise of a Global Power, the Democratic Revolution at Home, 1945-2000. New York: Viking, 2012.

Fried, Richard M. Nightmare in Red: The McCarthy Era in Perspective. New York: Oxford University Press, 1990.

Golden, Clinton S. and Harold J. Ruttenberg, The Dynamics of Industrial Democracy. New York: Harper, 1942.

Gordon, Colin. "Why No National Health Insurance in the U.S.?: The Limits of Social Provision in War and Peace, 1941-1948." Journal of policy history. 9, no. 3 (1997).

----------. Dead on Arrival: The Politics of Health Care in Twentieth-Century America. Princeton: Princeton University Press, 2003.

Gottschalk, Marie. The Shadow Welfare State: Labor, Business, and the Politics of Health-Care in the United States. Ithaca: ILR Press, 2000.

Gregory, James N. The Southern Diaspora: How the Great Migrations of Black and White Southerners Transformed America. Chapel Hill: University of North Carolina Press, 2010.

Griffith, Robert. The Politics of Fear: Joseph R. McCarthy and the Senate. Lexington: University Press of Kentucky, 1970.

Grossman, James R. Land of Hope: Chicago, Black Southerners, and the Great Migration. Chicago: University of Chicago Press, 1989.

Hacker, Jacob S. The Divided Welfare State: The Battle over Public and Private Social Benefits in the United States. New York: Cambridge University Press, 2002.

Hamby, Alonzo L. "The Vital Center, the Fair Deal, and the Quest for a Liberal Political Economy." The American Historical Review 77, no. 3 (June 1, 1972): 653-78.

Harris, Howell John. The Right to Manage: Industrial Relations Policies of American Business in the 1940s. Madison: University of Wisconsin Press, 1982.

Harrison, Bennett, and Barry Bluestone. The Great U-Turn: Corporate Restructuring and the Polarizing of America. New York: Basic Books, 1993. 
Haynes, John Earl. Red Scare or Red Menace?: American Communism and Anticommunism in the Cold War Era. Chicago: Ivan R. Dee, 1996.

Heineman, Kenneth J. A Catholic New Deal: Religion and Reform in Depression Pittsburgh. State College: Penn State University Press, 2005.

Hendricks, Rickey Lynn. A Model for National Health Care: The History of Kaiser Permanente. New Brunswick: Rutgers University Press, 1993.

Herling, John. Right to Challenge: People and Power in the Steelworkers Union. New York: Harper \& Row, 1972.

Hodgson, Godfrey. America in Our Time. Garden City: Doubleday, 1976.

Issel, William. Church and State in the City: Catholics and Politics in Twentieth-Century San Francisco. Philadelphia: Temple University Press, 2012.

Jacoby, Sanford M. Modern Manors: Welfare Capitalism Since the New Deal. Princeton: Princeton University Press, 1997.

Kersten, Andrew Edmund. Labor's Home Front: the American Federation of Labor during World War II. New York: New York University Press, 2006.

Klein, Jennifer. For All These Rights: Business, Labor, and the Shaping of America's PublicPrivate Welfare State. Princeton: Princeton University Press, 2003.

Krajcinovic, Ivana. From Company Doctors to Managed Care: the United Mine Workers' Noble Experiment. Ithaca: ILR Press, 1997.

Lacey, Michael James. eds. The Truman Presidency. New York: Cambridge University Press, 1989.

Lawson, Alan. A Commonwealth of Hope: The New Deal Response to Crisis. Baltimore: Johns Hopkins University Press, 2006.

Leff, Mark H. "Taxing the 'Forgotten Man': The Politics of Social Security Finance in the New Deal." The Journal of American History 70, no. 2 (1983): 359-81.

Lichtenstein, Nelson. State of the Union: A Century of American Labor. Princeton: Princeton University Press, 2002.

. Labor's War at Home: The CIO in World War II. New York: Cambridge University Press, 1982.

----------. The Most Dangerous Man in Detroit: Walter Reuther and the Fate of American Labor. New York: Basic Books, 1995. 
---------. "Class Politics and the State During World War Two." International Labor and Working-Class History 58, no. 1 (2000): 261-274.

Linkon, Sherry L., John Russo. Steeltown U.S.A.: Work and Memory in Youngstown. Lawrence: University Press of Kansas, 2002.

Lynd, Alice, and Staughton Lynd. Rank and File: Personal Histories by Working-Class Organizers. Boston: Beacon Press, 1973.

Lynd, Staughton, and Alice Lynd. The New Rank and File. Ithaca: ILR Press, 2000.

Lynd, Staughton. "We are All Leaders": The Alternative Unionism of the Early 1930s. Urbana: University of Illinois Press, 1996.

-. Fight Against Shutdowns: Youngstown's Steel Mill Closings. San Pedro: Singlejack Books, 1982.

McDonald, David. Union Man. New York: E. P. Dutton \& Co., Inc, 1969.

McQuaid, Kim. "Corporate Liberalism in the American Business Community, 1920-1940." The Business History Review 52, no. 3 (October 1, 1978): 342-68.

Metzgar, Jack. Striking Steel: Solidarity Remembered. Philadelphia: Temple University Press, 2000 .

Mills, C. Wright. The Power Elite. New York: Oxford University Press, 1956.

Miller, Sally M. and Daniel A. Cornford eds. American Labor in the Era of World War II. West Port: Praeger, 1995.

Mulcahy, Richard P. Social Contract For Coal Fields: United Mine Workers Welfare \& Retirement Funds. Knoxville: University of Tennessee Press, 2001.

Murch, Donna Jean. Living for the City: Migration, Education, and the Rise of the Black Panther Party in Oakland, California. Chapel Hill: University of North Carolina Press, 2010.

Nelson, Bruce. Divided We Stand: American Workers and the Struggle for Black Equality. Princeton: Princeton University Press, 2001.

-----------. "Organized Labor and the Struggle for Black Equality in Mobile during World War II." The Journal of American History 80, no. 3 (December 1, 1993): 952-88.

Nyden, Philip W. Steelworkers Rank-and-File: The Political Economy of a Union Reform Movement. New York: Bergin \& Garvey, 1984. 
-----------. The Transformation of Old Age Security: Class and Politics in the American Welfare State. Chicago: University of Chicago Press, 1988.

Phillips, Kimberley L. AlabamaNorth: African-American Migrants, Community, and WorkingClass Activism in Cleveland, 1915-1945. Urbana: University of Illinois Press, 1999.

Phillips-Fein, Kim. Invisible Hands: The Businessmen's Crusade Against the New Deal. New York: W. W. Norton \& Company, 2010.

Roof, Tracy. American Labor, Congress, and the Welfare State, 1935-2010. Baltimore: Johns Hopkins University Press, 2011.

Rose, James Douglas. Duquesne and the Rise of Steel Unionism. Urbana: University of Illinois Press, 2001.

Rosenberg, Samuel. American Economic Development Since 1945: Growth, Decline, and Rejuvenation. New York: Palgrave Macmillan, 2003.

Schrecker, Ellen. Many Are the Crimes: McCarthyism in America. Princeton: Princeton University Press, 1998.

Sholes, Elizabeth C. and Thomas E. Leary, "Philip Murray" in Bruce E. Seely ed. Encyclopedia of American Business History and Biography: Iron and Steel in the Twentieth Century. Bruccoli Clark Layman, Inc., and Facts on File, Inc., 1994.

Sullivan, Patricia. Days of Hope: Race and Democracy in the New Deal Era. Chapel Hill: University of North Carolina Press, 1996.

Theoharis, Jeanne, and Komozi Woodard. eds. Freedom North: Black Freedom Struggles Outside the South, 1940-1980. New York: Palgrave Macmillan, 2003.

Trotter, Joe William. Black Milwaukee: The Making of an Industrial Proletariat, 1915-45. Urbana: University of Illinois Press, 2007.

Trotter, Joe William and Nell Irvin Painter eds. The Great Migration in Historical Perspective: New Dimensions of Race, Class, and Gender. Bloomington: Indiana University Press, 1991.

Ulman, Lloyd, The Government of the Steel Workers' Union. New York: John Wiley and Sons, Inc., 1962.

Waddell, Brian. "Economic Mobilization for World War II and the Transformation of the U.S. State." Politics \& Society 22, no. 2 (June 1, 1994): 165-94.

Weigel, George and Robert Royal eds. Building the Free Society: Democracy, Capitalism, and Catholic Social Teaching. Washington: Ethics and Public Policy Center, 1993. 
Whitefield, Stephen J. The Culture of the Cold War. Baltimore: Johns Hopkins University Press, 1991.

Wolff, Richard D. Democracy at Work: A Cure for Capitalism. Chicago: Haymarket Books, 2012.

Wolff, Richard D., and Stephen A. Resnick. Economics: Marxian versus Neoclassical. Baltimore: The Johns Hopkins University Press, 1987.

----------. New Departures in Marxian Theory. New York: Routledge, 2006.

Zieger, Robert H. The CIO, 1935-1955. Chapel Hill: University of North Carolina Press, 1995. 